
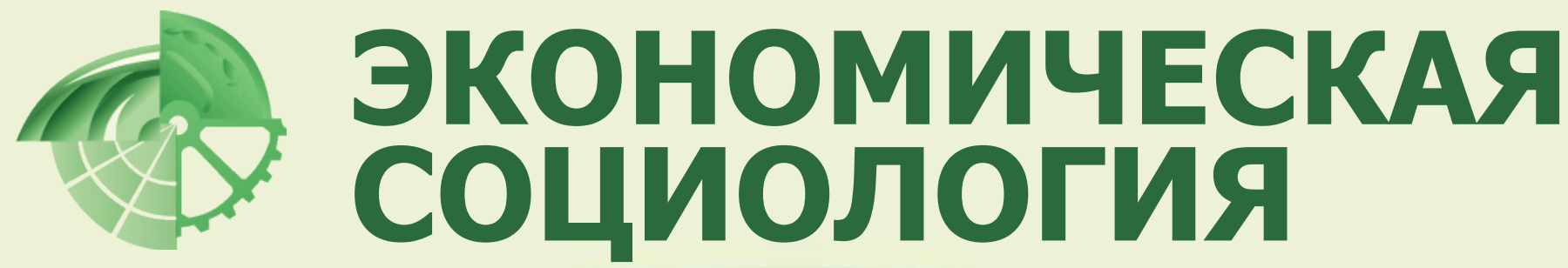

ISSN 1726-3247

Читайте в номере:

Интервью с Джеймсом Марчем

Доббин Ф. Формирование промышленной политики

Козина И. М. Люди заёмного труда: социальный состав и характеристики работы

Мокир Дж., Фотх Г.-И. Экономический рост в Европе в 1700-1870 гг.: теория и фактические свидетельства

Чириков И. С. Четыре способа определения организационных границ в социологии 
Экономическая социология

Т. 13. № 5. Ноябрь 2012

Электронный журнал

www.ecsoc.msses.ru

www.ecsoc.hse.ru

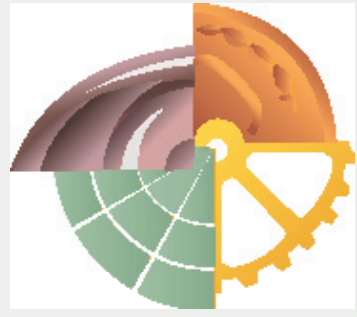

Журнал выходит пять раз в год:

№ 1 - январь

№ 2 - март

№ 3 - май

№ 4 - сентябрь

№ 5 - ноябрь

Учредители:

- Национальный исследовательский университет «Высшая школа экономики»

- В. В. Радаев

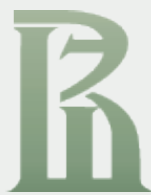

Редакция

Главный редактор: Радаев Вадим Валерьевич

Редактор выпуска: Соколова Татьяна Виленовна

Вёрстка: $\quad$ Мишина Мария Евгеньевна

Сотрудники редакции: Бердышева Елена Сергеевна Котельникова Зоя Владиславовна

Корректор:

Андрианова Надежда Викторовна

\section{Редакционный совет}

Богомолова Т. Ю. Новосибирский государственный университет

Веселов Ю. В. Санк-Петербургский государственный университет

Волков В. В. Европейский университет в СанктПетербурге

Гимпельсон В. Е. НИУ ВШЭ

Заславская Т. И. Московская Высшая школа социальных и экономических наук

Лапин Н. И. Институт философии РАН

Малева Т. М. Независимый институт социальной политики

Овчарова Л. Н. Независимый институт социальной политики

Радаев В. В. НИУ ВШЭ

(главный редактор)

Рывкина Р. В. Институт социально-экономических проблем народонаселения РАН

Хахулина Л. А. Аналитический центр Юрия Левады

Чепуренко А. Ю. НИУ ВШЭ

Шанин Т.

Московская Высшая школа социальных и экономических наук

Шкаратан О. И. НИУ ВШЭ 


\section{Содержание}

Вступительное слово главного редактора (В. В. Радаев) 5

\section{Интервью}

Интервью с Джеймсом Марчем:

«Хороший исследователь будет стремиться создать нечто стоящее независимо от того, приведёт ли это к каким-то последствиям»

(перевод Д. Ж. Ассалауовой)

\section{Новые тексты}

И. М. Козина

Люди заёмного труда: социальный состав и характеристики работы

\section{Новые переводы}

Ф. Доббин

Формирование промышленной политики: Соединённые Штаты,

Великобритания и Франция в период становления

железнодорожной отрасли (перевод Е. Б. Головляницььной)

\section{Расширение границ}

Дю. Мокир, Г.-И. Фотх

Экономический рост в Европе в 1700-1870 гг.:

теория и фактические свидетельства (перевод Ю. Каптуревского) 57

\section{Дебютные работы}

M. А. Неуважаева

Институциональные условия формирования негосударственных вузов в России. 102

\section{Профессиональные обзоры}

И. С. Чириков

Четыре способа определения организационных границ в социологии

\section{Новые книги}

\section{B. В. Радаев}

Предисловие к книге: Доббин Ф. 2012 (готовится к изданию).

Формирование промышиленной политики: Соединённые Штаты,

Великобритания и Франция в период становления железнодорожной отрасли.

М.: Изд. дом ВШЭ (серия «Социальная теория»). 


\section{Исследовательские проекты}

Издержки торговых компаний по поддержанию систем наличных и безналичных платежей (руководитель - B. B. Радаев)......

\section{Учебные программы}

Д. Х. Ибрагимова

Практикум по прикладному анализу финансового поведения населения

\section{Конфреренции}

Международная конференция «Укоренённость и за её пределами:

объясняют ли социологические теории экономическую реальность?», октябрь 25-28, 2012, Москва

Contents and Abstracts. 173

About the Authors 176 


\section{VR ВСТУПИТЕЛЬНОЕ СЛОВО ГЛАВНОГО РЕДАКТОРА}

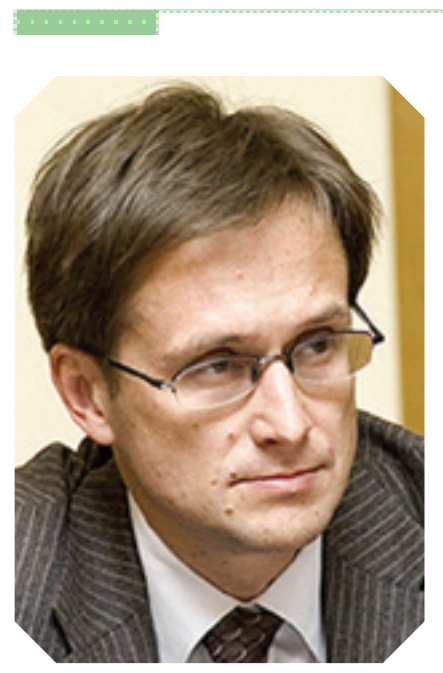

Свершилось! Конференция, которую в Высшей школе экономики мы готовили более полутора лет, наконец, состоялась и, кажется, станет главным событием не только этого года. Напомним, что речь идёт о международной конференции в Москве «Embeddedness and Beyond: Do Sociological Theories Meet Economic Realities?» («Укоренённость и за её пределами: объясняют ли социологические теории экономическую реальность?»), организованной как совместная конференция (interim conference) комитета «Хозяйство и общество» Международной социологической ассоциации и Исследовательской сети по экономической социологии Европейской социологической ассоциации при участии секции экономической социологии Американской социологической ассоциации. В конференции приняли участие более 200 социологов из Австралии, Англии, Бразилии, Германии, Канады, Новой Зеландии, России, США, Франции и других стран. Почётными докладчиками форума стали Фрэнк Доббин (Гарвардский университет), Карин Кнорр (Университет Чикаго), Гленн Морган (Университет Кардиффа), Дэвид Старк (Колумбийский университет, Нью-Йорк), Лоран Тевено (Высшая школа социальных наук, Париж), Брайан Уци (Келоггская школа менеджмента, Северо-Западный университет), Роберто Фернандес (Школа менеджмента им. Слоуна, Массачусетский технологический институт), Марион Фуркад (Университет Калифорнии, Бёркли).

Москва ещё не видела сразу такого количества звёзд мировой экономической социологии. А многие из этих звёзд впервые увидели Москву. Разумеется, мы неоднократно будем возвращаться к этой конференции с разными репортажами, обзорами и размышлениями. И начнём уже с этого номера. Надеемся также, что новые статьи некоторых участников конференции появятся на страницах нашего журнала.

Между тем жизнь возвращается в обычную колею, и наступает время представлять новый номер журнала «Экономическая социология».

В рубрике «Интервью» нас ожидает беседа с одним из патриархов теории организаций Джеймсом Марчем, почётным профессором менеджмента, политических наук и социологии Стэнфордского университета (США), который опубликовал ряд классических работ ещё в 1960-е гг. Профессор Марч рассказывает о теориях, изучающих принятие решений в организациях, о своей работе с Гербертом Саймоном, о любви к Достоевскому и о том, как он снял фильмы о «Войне и мире» Толстого и «Дон Кихоте» Сервантеса, чтобы использовать этот материал в своём лекционном курсе по проблемам лидерства. Это весьма необычное интервью, в котором оценки скандинавской и французской школ организационных исследований соседствуют с размышлениями о русской классической литературе, записано в Стэнфорде в 2012 г. И. С. Чириковым.

В рубрике «Новые тексты» публикуется статья И. М. Козиной, заведующей кафедрой методов сбора и анализа социологической информации НИУ ВШЭ, «Люди заёмного труда: социальный состав и характеристики работы». В статье анализируются новые формы трудовых отношений в условиях лизинга персонала (заёмного труда). На основе результатов первого масштабного опроса российских работников, занятых по схеме заёмного труда (в 2012 г. были опрошены более 1000 человек), приводится социальный портрет российских заёмных работников, характеризуются мотивы их трудоустройства и условия труда. 
В рубрике «Новые переводы» мы размещаем первую главу из книги «Forging Industrial Policy...» («Формирование промышленной политики...») одного из главных участников московской конференции Фрэнка Доббина, профессора факультета социологии Гарвардского университета (Кембридж, США). Перевод - E. Б. Головляницыной. В книге представлено объяснение устойчивых различий в промышленной политике Соединённых Штатов, Великобритании и Франции на примере анализа эволюции государственного регулирования железнодорожной отрасли в период её становления. Автор подчёркивает ключевую роль культурных смыслов в развитии рационализированных политических систем. Ранее мы уже публиковали заключение к данной книге в нашем журнале (2004. 5 (1): 45-62) и хрестоматии «Западная экономическая социология» (2004. М.: РОССПЭН; 607-631). Полностью книга выйдет в Издательском доме ВШЭ.

Наша новая рубрика «Расширение границ» предлагает статью Джоэля Мокира, профессора экономической истории факультета экономики Северо-Западного университета (Эванстон, США) и ГансаИоахима Фотха, профессора и научного сотрудника факультета экономики Университета Помпеу Фабра (Барселона, Испания) «Экономический рост в Европе в 1700-1870 гг.: теория и фактические свидетельства» из первого тома «Кембриджской экономической истории Европы Нового и Новейшего времени». В этой статье представлены обобщённые результаты современных исследований, посвящённых объяснению экономического роста. Перевод - Ю. Каптуревского. Напомним, что совсем недавно мы публиковали перевод главы из книги Мокира «Дары Афины: Исторические истоки экономики знаний» (2012. 13 (4): 81-94). В новом номере журнала мы продолжаем знакомить Вас, уважаемый читатель, с трудами этого интересного автора. Книга скоро выйдет в Издательстве Института Гайдара. Глава публикуется после дополнительного редактирования, с любезного согласия издателя.

В рубрике «Дебюты» публикуется работа M. А. Неуважаевой, студентки факультета социологии НИУ ВШЭ. В статье представлен критический анализ процесса формирования и развития негосударственного сектора высшего образования в России с позиции нового институционального подхода в экономической социологии. По результатам анализа глубинных интервью с основателями и преподавателями московских негосударственных вузов, а также анкетного опроса студентов предпринята попытка проследить структурацию поля негосударственных вузов и объяснить процессы институционального изоморфизма, характерные для негосударственного сектора высшего образования в России.

В рубрике «Профессиональные обзоры» представлен материал И. С. Чирикова, директора Центра внутреннего мониторинга и аспиранта факультета социологии НИУ ВШЭ, «Четыре способа определения организационных границ в социологии». Автором сделана попытка кодификации теоретических ресурсов социологии организаций, связанных с изучением организационных границ. Способы концептуализации организационных границ выделяются в зависимости от используемых базовых метафор: граница как «мембрана» («клапан»), граница как «конвенция», граница как «интерфейс» и граница как «лицо» («передний план»). В обзоре обсуждаются также общие концептуальные ограничения этих подходов.

В рубрике «Новые книги» публикуется моё предисловие к уже анонсированной выше книге Фрэнка Доббина «Формирование промышленной политики...», которая готовится к изданию в переводе E. Б. Головляницыной. Автор книги показывает, что сердцевиной структуры государственной власти, основой всего политического порядка оказывается особая, присущая именно данному обществу политическая культура, помогающая основным игрокам интерпретировать политический порядок и вырабатывать специфические, идеологически нагружённые смыслы, а они, в свою очередь, формируют парадигму промышленной политики. 
В рубрике «Исследовательские проекты» мы знакомим Вас с только что завершимся исследовательским проектом «Издержки торговых компаний по поддержанию систем наличных и безналичных платежей», выполненным по заказу Ассоциации компаний розничной торговли коллективом Лаборатории экономико-социологических исследований НИУ ВШЭ. Целью исследования является изучение величины издержек продовольственных и непродовольственных торговых компаний, связанных с поддержанием систем наличных и безналичных платежей (применительно к банковским картам разных типов). Исследование представляет собой попытку ответить на вопрос, что мешает распространению безналичных платежей за товары и услуги с точки зрения розничных компаний.

В рубрике «Учебные программы» предлагается «Практикум по прикладному анализу финансового поведения населения» Д. Х. Ибрагимовой для слушателей магистерской программы «Прикладные методы социального анализа рынков» факультета социологии НИУ ВШЭ.

Наконец, в рубрике «Конференции» мы начинаем знакомить Вас с материалами о прошедшей международной конференции по экономической социологии, состоявшейся в Высшей школе экономики $25-$ 28 октября 2012 г. В этом номере публикуются репортажи о двух первых пленарных заседаниях конференции, подготовленные для портала НИУ ВШЭ. Видеозаписи пленарных сессий и мини-интервью с участниками конференции доступны по адресу URL: http://www.esconf2012.hse.ru/

В заключение ещё раз обращаем Ваше внимание на то, что в новом году журнал ожидают серьёзные перемены. 


\section{Интервью с Джеймсом Марчем: «Хороший исследователь будет стремиться создать нечто стоящее независимо от того, приведёт ли это к каким-то последствиям»}

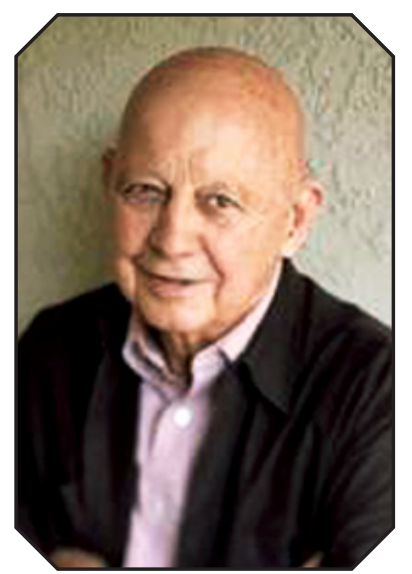

МАРЧ Джеймс

(March, James) почётный профессор

менеджмента, политических наук и социологии Стэнфрордского университета (Стэнфорд, США).

Email: march@stanford. edu

Перевод с англ. Даны Ассалауовой.
- Вы приобрели известность, изучая процессы принятия решений в организащиях. Как бы Вы могли охарактеризовать существующие в этой области подходы для тех, кто не занимается данной проблематикой?

— Я не думаю, что смогу дать стоящую классификацию. Но скажу, что многие из подходов уходят корнями в теорию статистических решений и в некоторых своих вариациях, безусловно, тесно связаны с экономической наукой. Базовой предпосылкой в данном случае является наличие актора с устойчивой функцией полезности и полностью информированного как о том, какие альтернативы существуют, так и о последствиях выбора той или иной альтернативы. Такой актор следует логике максимизации ожидаемой выгоды. Подобная модель в той или иной форме определяет очень многое в интересующей нас области. Большинство исследователей, занимающихся изучением организаций, могут не соглашаться со всеми упомянутыми предпосылками, но они часто воспринимают общую рамку как данность. Они ставят вопросы о том, каким образом акторы в организациях формируют альтернативы, как определяют свои цели и т. п. Затем появляются вариации на эту тему, например, концепция ограниченной рациональности. Мы говорим: «Да, организации и люди в них принимают решения, учитывая последствия выбора той или иной альтернативы, но они не могут знать всех альтернативных вариантов, они вынуждены искать эти варианты; люди также могут не осознавать всех последствий, они вынуждены собирать информацию о них; наконец, люди имеют множество целей вместо одной неизменной функции полезности». Модель ограниченной рациональности использует те же предпосылки, но несколько модифицирует их. Ещё одно не менее важное направление в этой области образует подход, фокусирующий внимание на том, что я называю логикой уместности (logic of appropriateness): мы предполагаем, что актор совершает действие, исходя не из возможных последствий, но спрашивая себя: «Какова моя идентичность? Что это за ситуация? Как я должен поступить в данной ситуации исходя из своей идентичности?» Действие, таким образом, не определяется его последствиями, а опирается на идентичность человека. Это более традиционный социологический подход, развивающийся в рамках некоторых направлений теории принятия решений. Однако, думаю, будет справедливо сказать, что большинство исследователей, изучающих процессы принятия решений в организациях, так или иначе используют теорию статистических решений или концепцию ограниченной рациональности. 
- Это происходит вследствие того, что, используя социологический подход, мы не можем дать какие-либо определённые рекомендаџии менеджерам организаџий? Или есть другие причины?

- Вы же знаете, что влияние различных дисциплин на культуру и контекст того, как мы думаем, это невероятно сложный вопрос для изучения. Понятия, которыми пользуются в США и, я думаю, в большинстве западных стран, ориентированы на описание последствий. Если я попрошу Вас объяснить своё решение, Вы скажете: «Я сделал это, потому что ожидал наилучшего результата от данного решения». Ответ: «Я поступил так, потому что это было уместным», - был бы прекрасным, но он не является распространённым в нашей культуре, хотя в повседневной жизни люди часто так говорят. Тем не менее об организациях мы, несомненно, говорим в терминах описания последствий. В этом смысле вклад социологов относительно незначим. Более того, многие из них сами описывают организационные процессы языком следствий. Таким образом, этот способ описания присутствует и в социологии.

\section{— Какое место в этой классификации Вы отвели бы модели мусорной корзины ${ }^{1}$ ?}

— Я думаю, она относится к группе концепций ограниченной рациональности, поскольку обращается к проблемам внимания и вопросам поведения множества акторов с множественными намерениями. В целом эти работы - пусть и не по содержанию, но по духу — тяготеют к описанию действий с точки зрения результата, к которому они приводят. Представим ситуацию, где люди просчитывают последствия своего поведения. Модель мусорной корзины показывает, что некоторые из альтернатив не определяются акторами заранее, но часто альтернативы возникают в ходе самого действия, а в своём поведении акторы руководствуются не столько логикой, сколько тем, как разворачивается ситуация во времени. Таким образом, большая часть решений, принимаемых акторами, не может быть описана схемой «действие - следствие». Тем не менее она сохраняется в качестве общей рамки исследований.

- Вы упомянули направление, где ичентральным кониептом является понятие уместности. Каковы истоки этой теоретической традиции? Каких современных исследователей Вы могли бы причислить $\kappa$ сторонникам данного направления?

- Хороший вопрос. Я думаю, истоки этого подхода можно найти в социологических работах, посвящённых проблематике социальных ролей. Их авторы утверждали, что поведение человека обусловлено его представлениями о роли, которую он играет. Хорошим примером являются работы Ирвинга Гофмана (Erving Goffman). Данное направление также заимствует идеи таких экономистов, как Ричард Нельсон (Richard Nelson) и Сидни Уинтер (Sidney Winter), исследующих эволюцию правил и процесс их отбора. В основе их рассуждений лежит представление о системе, функционирующей на базе идентичности. Джордж Акерлоф (George Akerlof) из университета Калифорнии в Бёркли пытается ввести понятие «идентичность» в экономическую теорию. Есть ещё один человек, который, с моей точки зрения, за последние годы сделал очень многое в этом направлении, — это Йохан Олсен, мой коллега из Норвегии. Мы написали вместе несколько статей, в которых постарались показать специфику и значимость подхода, опирающегося на понятие идентичности. Он работает в области политических наук, поэтому нашим объектом выступали политические организации, однако только ими подход не ограничивается.

\section{- С каких работ Вы порекомендовали бы начать знакомство с данной областью?}

— Если говорить о моих исследованиях, то это книги, написанные мною вместе с Гербертом Саймоном, Ричардом Сайертом и Йоханом Олсеном [March, Simon 1958; Cyert, March 1963; March, Olsen 1995].

1 Модель мусорной корзины (garbage can model), разработанная Дж. Марчем и Й. Олсеном (Johan P. Olsen), фокусируется на том, как происходит процесс принятия решений в организациях в ситуации высокой неопределённости. Действия акторов не могут быть описаны схемой «проблема - поиск альтернатив — наиболее эффективное решение», а имеют случайный характер. - Здесь и далее примеч. перев. 
Также есть два больших сборника моих статей: «Decisions and Organizations» («Решения и организации») и «The Pursuit of Organizational Intelligence» («В поисках организационного разума») [March 1988; 1999]. Думаю, это будет хорошим введением в тему.

- Расскажите, пожалуйста, о Вашем сотрудничестве с Гербертом Саймоном. Как началась совместная работа?

— Я сотрудничал с ним очень недолго. Мы написали одну книгу, и, насколько помню, работа над ней длилась всего три года. После этого мы оставались друзьями и, несомненно, обменивались мнениями и идеями, но результатом нашей совместной деятельности является только одна эта книга. Фактически он нанял меня для написания этой книги вскоре после того, как я защитил диссертацию. Мы встретились дождливым вечером в отеле, в Коннектикуте, быстро нашли общий язык и решили работать вместе. Однако, как я уже сказал, это было недолгое сотрудничество, и после написания нашей совместной книги Саймон обратился к изучению искусственного интеллекта, уделяя этой теме практически всё своё время.

\section{— Ваша общая книга была результатом исследовательского проекта?}

- Да, несомненно. Бернард Берельсон (Bernard Berelson), работавший тогда в Фонде Форда ${ }^{2}$, хотел создать в бихевиористской науке то, что он называл корпусом знания (state of the knowledge). Позднее он написал об этом книгу, но сначала выбрал нескольких человек и предложил им описать фундаментальные научные основания в различных областях. Герберту досталось направление, связанное с теорией организаций, и он нанял меня. Довольно простая история. Хотя нет, всё было немного сложнее, поскольку одновременно я работал над совместной книгой с Ричардом Сайертом, так что фактически мы обменивались идеями втроём.

— Что Вы могли бы сказать о концепџии ограниченной раџиональности сегодня? Она по-прежнему столь влиятельна в области организационных исследований?

— Думаю, что большинство идей, сформулированных в рамках этой модели, сегодня рассматриваются как само собой разумеющееся. Многие исследователи принимают на веру её основные положения: люди никогда не могут обладать полной информацией; существуют проблемы, связанные с вниманием; организации действуют согласно принципу приемлемости (satisfice), а не максимизации полезности. Я могу ошибаться, но полагаю, что эта часть знания более-менее конвенциональна. Разумеется, есть экономисты, которые к этому относятся критически, кто-то и из исследователей организаций скажет, что это не главная проблема, а центральным понятием, к примеру, является власть: до тех пор, пока вы не начнёте изучать проблематику власти в организации, вы не сможете понять, как в ней действительно принимаются решения. Книги, которые я писал с Сайертом и Олсеном, по-прежнему часто цитируются (хотя не уверен, что их столь же часто читают). Однако я сказал бы, что фокус современных исследований поменялся: внимание сейчас сосредоточено не на процессах принятия решений как таковых. Люди, которые занимаются изучением принятия решений, по-прежнему опираются на эту традицию, однако многие социологи сегодня выходят за её пределы, обращаясь к вопросам диффузии, распространения различных процессов и явлений в организациях. Этот акцент не был характерен для более ранних исследований.

2 Фонд Форда (The Ford Foundation) - американская некоммерческая благотворительная организация, целями деятельности которой являются борьба с бедностью, развитие международного сотрудничества, распространение демократических ценностей. 
— Тем не менее они связань друг с другом.

- Да, конечно. Диффузия является базовым процессом для распространения различных типов действия. Если вы исследуете то, как происходит организационное научение, то вашим предметом становятся как действия, основанные на сопоставлении выгод и издержек, так и научение на основе собственного опыта и опыта других (а это и есть диффузия), а также процесс вариации и (или) отбора наиболее устойчивых типов действия, изучаемый в рамках эволюционных подходов. Таким образом, идеи разных подходов, безусловно, пересекаются, хотя каждый из них фокусируется на определённом аспекте.

- Bы упомянули процесс организационного научения. Можем ли мы использовать такие концепты, как научение, идентичность и т. д., описывающие поведение индивидуальных акторов, изучая организации, то есть на групповом уровне? Не становимся ли мы в этом случае на путь антропоморфизации коллективностей?

— Я не вижу причины этого избегать. Просто вы должны ясно видеть, когда именно данный способ описания даёт вам преимущество. Не думаю, что существуют серьёзные основания, не позволяющие говорить о процессах научения организаций. Если вы рассуждаете об обучении индивидуальных акторов, то возникает вопрос: какие именно молекулы индивидов обучаются? И можем ли мы в таком случае говорить о научении людей? При исследовании организационных правил и их изменений, подозреваю, мы имеем дело с организационным научением. Это вопрос прагматический, не философский.

— Однако когда социологи используют эти понятия, описывая индивидуальное поведение, в действительности они не говорят о молекулах...

- Не говорят; и в этом вся суть. Если вы биолог, то научение представляется вам биологическим процессом, и говорить о нём как об индивидуальном поведении вы не можете. Да, это несомненно верное утверждение с точки зрения биологии. Но если эти концепты окажутся практичными и полезными для анализа на уровне индивидов, я буду их использовать. А если они окажутся практичными и полезными на организационном уровне, я тоже буду их использовать.

— Каковы главные идеи, конституирующие исследования организациинного научения?

— Прежде всего, нужно понять, что некоторые авторы, работающие в этом направлении, определяют научение как улучшение, а любое улучшение - как научение. Организация производит продукт с меньшими издержками и в течение меньшего времени - это научение. Я думаю, такое определение ошибочно, потому что необходимо рассматривать научение как механизм, который позволяет организациям и их участникам изменяться, а значит, важно рассматривать, приводит ли этот механизм к улучшениям, и при каких условиях это происходит. Не буду поэтому говорить об исследователях, которые рассматривают научение как улучшение, а буду говорить о тех, кто фокусируется на механизмах научения. Эти учёные выделяют три главных механизма организационного научения. Один из этих механизмов представляет собой повторение того, что сработало в прошлом, и избегание тех образцов, которые оказались неуспешными (replication of success). Данный механизм является невероятно важным при изучении деятельности организаций, и многие исследователи продолжают этим заниматься. Второй механизм - это то, как именно люди научаются, или то, как они рассказывают о своём опыте; иными словами, как конструируется история, описывающая эти процессы. Исследователи в этой области смотрят на каузальную структуру историй, основанных на опыте обучения акторов. Третий механизм - это научение на основе опыта других (learning from others). Большое количество исследователей интересует то, как происходит передача опыта, ведь огромный объём информации о мире мы получаем не из собственного опыта, а от других, например от учителей, из книг и т. п. Организации, в 
свою очередь, являются ещё одним каналом передачи знания. Эти три механизма как раз и описываются в работах, посвящённых организационному научению. Часть исследований представляют собой, по сути, доказательство теоремы: «Если вы будете сегодня продолжать следовать правилам, принёсшим успех в прошлом, то при определённых обстоятельствах можете добиться улучшения и достижения некоторого оптимума. Другие же условия приведут к тому, что тот же способ действия окажется неудачным». Таковы главные результаты научных работ, показывающих действие механизма повторения лучших практик: они предсказывают возможные последствия того или иного решения (если соблюдены все исходные условия), однако не основываются на эмпирических данных. Другая область исследований фокусируется на эмпирическом изучении процессов повторения лучших практик, а также историй, которые рассказывают о данных процессах. Изучение того, как люди рассказывают истории, является крайне интересной областью. Здесь мы, конечно, испытываем некоторые трудности, так как история (history) является продуктом сложных взаимодействий различных переменных. Кроме того, мы также имеем малое количество эмпирического материала, выявить каузальную структуру которого с помощью статического анализа почти невозможно. Тем не менее многие это делают, и делают различными способами. Таким образом, изучение того, какие ошибки делают люди, что именно они делают и какие истории рассказывают об этом, составляет важную часть работ в области организационного обучения.

- Это действительно интригующее направление. Джим, Bы известны не только благодаря своим книгам и статьям, но и фильмам. Я был поражён, когда посмотрел один из них, посвямённый «Войне и миру» ${ }^{3}$. Мне кажется, российским читателям было бы особенно интересно усльимать об этом, ведь все они так или иначе читали хотя бы часть книги...

— В моей выборке доля таких людей составляет 100\% (смеётся).

— Итак, скажите, почему кино? Трудно представить себе учёного, занимающеггося производством фильмов.

— Я объясню, но это будет своего рода рационализация. Фильмы — это очень мощный коммуникативный инструмент. Фильм может сделать то, чего нельзя добиться с помощью книги или лекции: этот инструмент гораздо более убедителен и нагляден. Для меня это также было весело. Однажды мне предложили попробовать снять фильм об учебном курсе, в котором я использовал «Войну и мир» Толстого и «Дон Кихота» Сервантеса. Сначала я отказывался, так как действительно полагал, что фильм, в котором я буду читать лекции, не будет интересным. На что мне ответили: «Необязательно читать лекции. Делайте то, что Вам хотелось бы делать». Режиссёром этого проекта стал Стив Шектер (Steve Schecter), человек с богатым воображением. Мы нашли общий язык и стали работать вместе, и это было действительно весело, несмотря на то, что довольно часто мы не соглашались друг с другом. Тем не менее этот проект принёс мне массу удовольствия. Я побывал в России, в Испании...

— Почему Вы выбрали «Войну и мир» Толстого? Учёные, исследующие организащии в России, никогда не рассматривали это произведение с точки зрения организаџионной теории, и я был удивлён, узнав, что это делают в США.

- Всё очень просто. Одним из важных элементов моего курса являлся следующий вопрос: что побуждает масштабное коллективное действие, что мотивирует и направляет людей? Лидерство в таких случаях требует серьёзных обязательств. Обычно утверждается, что масштабные действия совершаются, поскольку направляются ожиданиями больших последствий. Я же утверждал, что люди, берущие на себя функции лидера в силу того, что ожидают каких-то больших последствий, очень скоро будут разочарованы. Это подтверждается историческими примерами. Вы, таким образом, находитесь в ситуации,

3 URL: http://www.gsb.stanford.edu/news/bmag/sbsm0305/leadership2.shtml 
когда ваш лидер уже не верит в то, что вы делаете, относится к этому цинично, ему, по большому счёту, все равно, и это становится реальной проблемой. В этом смысле Толстой предлагает хороший аргумент, суть которого заключается в том, что не лидеры, а обыкновенные люди делают историю. Огромное количество обыкновенных людей, сложным образом связанных друг с другом. В своём курсе я хотел продемонстрировать мысль о том, что само по себе лидерство может не играть большой роли, и Толстой, несомненно, даёт возможность сделать это.

- Не был ли предложенный формат сюрпризом для учащихся бизнес-школь? Не разочаровались ли они в своём стремлении быть лидерами?

- (Смеётся.) Да, я полагаю, многие из них выбрали мой курс, так как имели определённые представления о важности лидерства. Надеюсь, они смогли увидеть альтернативный взгляд, предложенный в «Войне и мире». Это потрясающий роман.

— И всё же, каким образом Толстой способен помочь людям руководить организациями?

- В моём курсе лекция о «Войне и мире» предваряет лекцию о «Дон Кихоте». Делая кино, мы изменили последовательность: фильм о «Войне и мире» студенты должны смотреть раньше, чем «Дон Кихота», потому что в последнем фильме содержится ответ. Вы перестаёте действовать исходя из логики возможных последствий, когда перестаёте быть уверенными в их действенности. Ваша идентичность определяет ваши действия. Дон Кихот говорит, что знает, кем является: он рыцарь, и он поступает как рыцарь, несмотря на тот факт, что его поведение может порождать самые разные типы следствий.

— Именно так действует Кутузов...

- Да. Курс мы закончили фильмом о Дон Кихоте. По своей сути это произведение оптимистично. «Война и мир» предлагает не слишком воодушевляющий взгляд на действительность. Тем не менее, мне кажется, самым замечательным в этом произведении является то, с какой страстью Толстой описывает обычные события. Охота, бал — ко всему этому он относится с большим вниманием и любовью. Его симпатия к Наташе в некотором смысле безумна. Девушка потакает собственным желаниям, задириста, но он пытается видеть в ней её красоту. Даже в сражении он может разглядеть красоту. Я не знаю, помните ли вы отрывок, в котором солдаты купаются в пруду? Это по-настоящему уродливая сцена. Тем не менее и в ней Толстому удаётся сделать прекрасный портрет человека: можно наслаждаться красотой жизни даже тогда, когда уже ничто не имеет значения. Возвращаясь к «Дон Кихоту», я сказал бы, что сам факт отсутствия значимости последствий перестаёт вас волновать.

— Это очень интересно. Я хотел бы понять, как идеи Толстого о роли лидера в истории могут быть применены для описания научной деятельности. Какова роль руководителя в научной работе?

— Любое исследование имеет очень короткий «срок годности»; особенно, если речь идёт о перспективной области, где ваша работа в конце концов всегда замещается другими. Вы тратите огромное количество времени и усилий в попытке создать то, что не утратит своей значимости 10 , возможно 20, лет спустя. Однако разве можно предугадать это заранее? Я утверждаю, что будущие результаты этой работы не главное. Суть в том, что хороший исследователь будет стремиться создать нечто стоящее, независимо от того, приведёт ли это к каким-то последствиям.

— Я понял Вас. Приводили ли Вы другие примеры из русской литературы на лекциях?

- Да, я использовал поэзию Анны Ахматовой в переводе. У неё есть замечательное стихотворение, которое начинается так: «Меня, как реку, / Суровая эпоха повернула...» - и заканчивается строчками: 
«Но если бы оттуда посмотрела / Я на свою теперешнюю жизнь, / Узнала бы я зависть, наконец...». Я просил студентов прочитать это стихотворение, мы могли говорить о нём часами, потому что оно действительно прекрасно. Своим студентам я говорил, что они могут выбрать любое литературное произведение, и я покажу им, почему оно значимо для изучения организаций.

— Можем ли мы попробовать сделать это сейчас?

— Да, конечно. Только если Вы выберете произведение, с которым я знаком.

- Мойлюбимьй писатель - Достоевский.

— Вы читали «Идиота»?

- Да, конечно.

— На самом деле, для «Идиота» будут верны мои рассуждения о «Дон Кихоте», потому что «идиот» в этом произведении отнюдь не является идиотом. Он знает, кем является, но в жизни оказывается недостаточно организованным, в отличие от людей, окружающих его. Он действует, не обращая внимания на последствия, и опять-таки это вопрос идентичности. Идентичность является главной причиной, определяющей все его действия, и жизнь героя выстраивается вокруг представлений о самом себе, а не вокруг ожидания возможных последствий. Князю Мышкину было нелегко, но он обладал целостным пониманием того, почему совершает те или иные поступки. И именно поэтому этот пример столь важен для нас.

- Но можем ли мы сказать то же самое, к примеру, о Раскольникове из «Преступления и наказания»?

— Это более сложный случай Я не отрицаю всей важности ориентации на результат и думаю, было бы интересно исследовать эти аспекты одновременно. Многие хорошие люди переживают о последствиях своих действий, однако ошибочным будет связывать свои поступки лишь с ожидаемыми последствиями. Мне нравится то, что герои Достоевского или Толстого описаны со всех тех сторон, которые только можно себе представить, говоря о человеке. Думаю, вера Чехова в то, что история не может быть понята полностью, - это тоже важная вещь. В каком-то смысле Чехов занимает противоположную позицию по отношению к Толстому, в любом случае дающему читателю интерпретацию рассказанного. Чехов этого не делает и оставляет нам шанс самим найти смысл истории, будучи уверенным в том, что жизнь нельзя понять. Это представляется мне важным уроком.

- Интересная точка зрения. И последний вопрос. Вы известны как основатель Скандинавского консорииума организационных исследований (The Scandinavian Consortium for Organizational Research) $u$ потому очень хорошо знакомы с европейскими учёными. Как вы думаете, отличается ли европейская традищия исследования организаций от американской?

- Да, и довольно выгодным образом. Я думаю, наиболее важным в любой научной области является поддержание границ, что позволяет развиваться группам различных подходов. Если бы все были полностью встроены в существующую систему, то новые направления могли бы и не появиться вовсе. Очевидно, что существуют разные классификации европейских исследований, но я думаю, что французские учёные - например, небезызвестный Мишель Крозье (Michel Crozier) ${ }^{4}$ — видят структуру социальной науки, её отношения к философии и публичной политике в совершенно другой перспективе.

4 Французский социолог, известный исследованиями бюрократических структур во Франции. 
Мои французские коллеги с одинаковым успехом публикуются в академических журналах и главной парижской газете «Le Monde». Они являются частью французской интеллигенции, и их видение мира напоминает то, как себе мыслят окружающую действительность аристократы-интеллектуалы.

- Они критически относятся к той роли, которую формальные организации играют в современном мире? Или же поддерживают их?

- В целом они склонны критиковать решения правящих кругов страны, тем не менее являясь их частью. Бурдьё входил в академическую элиту, сегодня в неё входит Крозье. Они проводят массу времени, консультируя людей из бизнеса, правительственных организаций и проч. Так устроена французская социальная наука. Мне представляется, что во Франции реальной властью обладает группа инженеров, успешно интегрированных в академическую среду, которая, в свою очередь, тесно связана с политической жизнью через СМИ и публичные дискуссии. Мои друзья - исследователи организаций во Франции гораздо более активно взаимодействуют с правительством, нежели в США, где дистанция между государством и учёными действительно велика. Один мой знакомый физик, переводивший некоторые из моих лекций из курса о лидерстве и в итоге написавший об этом целую книгу (переведённую впоследствии на английский), несколько лет был главным научным советником премьерминистра Франции.

Учёные в Скандинавских странах более прагматичны, более склонны работать с данными, нежели углубляться в теоретические изыски. Финны, однако, в этом вопросе ближе к немецкой академической традиции: их подход в большей степени философский, фундаментальный. На этом фоне особенно заметны англичане, чьи работы с 1970-х годов по некоторым причинам, представляющим социологический интерес, в наибольшей степени подверглись влиянию постмодернизма. Английских учёных глубоко волнует то, как конструируется социальная реальность и другие вопросы того же порядка. Таким образом, стиль английских, новозеландских, австралийских исследований является постмодернистским в гораздо более сильной степени, чем в любой другой стране. Это действительно интригует. Порой немного раздражает, но в целом выглядит многообещающе.

- Спасибо за столь интересное интервью! Надеюсь, мы сможем последовать Вамему примеру и активнее использовать русскую литературу в собственных организационных исследованиях.

Беседовал Игорь Чириков Стэнфорд, 6 марта 2012 г.

Приложение

\section{Основные работы Джеймса Марча}

Augier M., March J. G. (eds). 2002. Economics of Change, Choice, and Organization: Essays in Memory of Richard M. Cyert. Cheltenham, UK: Edward Elgar Publishing, Ltd.

Augier M., March J. G. (eds). 2004. Models of a Man: Essays in Memory of Herbert A. Simon. Cambridge, MA: MIT Press.

Cohen M. D., March J. G. 1974. Leadership and Ambiguity: The American College President. New York, NY: McGraw-Hill.

Cyert R. M., March J. G. 1963. A Behavioral Theory of the Firm. Englewood Cliffs, NJ: Prentice-Hall. 
Eulau H., March J. G. 1969. Political Science. Englewood Cliffs, NJ: Prentice-Hall.

Gelbaum B. R., March J. G. 1969. Mathematics for the Social and Behavioral Sciences: Probability, Calculus and Statistics. Philadelphia, PA: W. B. Saunders Co.

Lave Ch. A., March J. G. 1975. An Introduction to Models in the Social Sciences. New York: Harper and Row.

March J. G. (ed.). 1965. Handbook of Organizations. Chicago, IL: Rand McNally.

March J. G. 1980. Autonomy as a Factor in Group Organization: A Study in Politics. New York: Arno Press.

March J. G. 1988. Decisions and Organizations. Oxford: Basil Blackwell.

March J. G. 1994. A Primer on Decision Making: How Decisions Happen. New York, NY: The Free Press. 1994.

March J. G. 1995. Fornuft og Forandring: Ledelse $i$ en Verden Beriget av Uklarhet. Copenhagen: Samfundslitteratur.

March J. G. 1999. The Pursuit of Organizational Intelligence. Oxford: Blackwell Publishers.

March J. G. 2005. Szervezeti tanulás és döntéshozatal. Budapest: Alinea Kiadó.

March J. G. 2005. Valg, Vane og Vision: Perspektiver på Aspiration og Adfard. Copenhagen: Samfundslitteratur.

March J. G. 2008. Explorations in Organizations. Stanford, CA: Stanford University Press.

March J. G. Forthcoming. The Ambiguities of Experience. Ithaca, NY: Cornell University Press.

March J. G., Olsen J. P. 1976. Ambiguity and Choice in Organizations. Bergen, Norway: Universitetsforlaget.

March J. G., Olsen J. P. 1989. Rediscovering Institutions: The Organizational Basis of Politics. New York: Free Press; Macmillan.

March J. G., Olsen J. P. 1995. Democratic Governance. New York, NY: The Free Press.

March J. G., Schulz M., Zhou X. 2000. The Dynamics of Rules: Change in Written Organizational Codes. Stanford, CA: Stanford University Press.

March J. G., Simon H. A. 1958. Organizations. New York: Wiley; см. также: 1993. 2nd ed. Oxford: Blackwell Publishers.

March J. G., Weil T. 2003. Le leadership dans les organizations.. Paris: Les Presses de l'École des Mine.

March J. G., Weil T. 2005. On Leadership. Oxford, UK: Blackwell Publishers. 
March J. G., Weissinger-Baylon R. (eds). 1986. Ambiguity and Command: Organizational Perspectives on Military Decision Making. Cambridge, MA: Ballinger.

\section{Литература}

Cyert R. M., March J. G. 1963. A Behavioral Theory of the Firm. Englewood Cliffs, NJ: Prentice-Hall.

March J. G. 1988. Decisions and Organizations. Oxford: Basil Blackwell.

March J. G. 1999. The Pursuit of Organizational Intelligence. Oxford: Blackwell Publishers.

March J. G., Olsen J. P. 1995. Democratic Governance. New York, NY: The Free Press.

March J. G., Simon H. A. 1958. Organizations. New York: Wiley. 


\section{НОВЫЕ ТЕКСТЫ}

\section{И. М. Козина}

\section{Люди заёмного труда: социальный состав и характеристики работы}

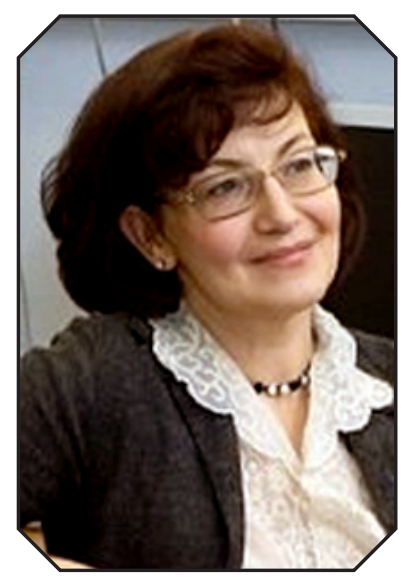

\section{КОЗИНА Ирина}

Марксовна — кандидат социологических наук, профессор, заведующая кафредрой методов сбора и анализа социологической информации НИУ ВШЭ (Москва, Россия).

Email: ikozina@hse.ru
Статья посвящена анализу новых форм трудовых отношений в условиях лизинга персонала (заёмный или агентский труд). В теории человеческого капитала заёмный труд предстаёт уделом маргинальных групп на рынке труда и занимает одну из низших ступеней в иерархии современных форм занятости с точки зрения сочиальных гарантий работников, поэтому сочиальная изена повышения гибкости трудового рынка может быть чрезмерно высокой и выражаться в дискриминачии заёмных работников, вытеснении их из первичного сектора рынка труда, превращении в работающих бедных. Автор рассматривает проблемь агентской занятости в категориях социальной защищеённости в сфере труда, выстраивая аргументацию вокруг обсуждения ключевых моментов, характеризующих заёмную рабочую силу: социальный состав, мотивы трудоустройства, оценки условий труда, удовлетворённость работой и проч.

Эмпирическую базу работь составили данные опроса 1012 работников, занятых на условиях заёмного труда в агентствах Kelly Services, Adecco и Anсог в семи российских регионах.

Результаты исследования показывают, что общая структура представлений об агентской занятости противоречива, и это отражает процесс формирования разных запросов в сфере труда, в том числе и запрос на гибкую занятость. В отличие от большинства стран, в составе российских заёмных работников преобладают молодые люди с высоким уровнем образования, которые воспринимают заёмный труд как ступеньку к устойчивой занятости. В долгосрочной перспективе заёмные работники ориентированы на стабильную позичию на рынке труда и стандартные трудовые отношения. Делается вывод о том, что трудовые практики в сфере заёмного труда не носят дискриминационного характера и мало чем отличаются от общей картины на российском рынке труда в ицелом.

Ключевые слова: заёмный труд; агентская занятость; трудовые отношения; социальная защищённость. 


\section{Определение понятий и проблемная ситуация}

Самым простым образом заёмный, или лизинговый, труд определяется как форма непрямого трудового найма ${ }^{1}$. Работник заключает договор с агентством - посредником (частным агентством занятости), а оно направляет его для выполнения работы в другую организацию. Таким образом, основная особенность лизинга персонала - это то, что работники не являются сотрудниками фирмы, в которой они фактически трудятся ${ }^{2}$. Ответственность работодателя в данной схеме найма размыта: одна организация (агентство) заключает договор с работником, производит социальные отчисления и выплачивает зарплату; другая организация (фирма-пользователь) предоставляет работу, контролирует её выполнение, даёт производственные задания. Возникающие трудовые отношения имеют нетрадиционную форму с участием трёх сторон (работник - агентство — фирма-пользователь), которая пока не предусмотрена российским трудовым законодательством, поэтому представляет собой определённые сложности, прежде всего с точки зрения правового статуса работника. Другая проблема для работников, занятых на условиях лизинга, связана с отсутствием гарантий продления контракта: работа в этом случае изначально носит временный, проектный характер.

С учётом этих особенностей заёмный труд можно определить как одну из разновидностей нестандартной (неустойчивой, нетипичной) занятости наряду с работой по прямым трудовым договорам временного характера, работой без оформления трудовых отношений и проч. [Гимпельсон, Капелюшников 2005: 8]. Нестандартность определяется относительно традиционных условий занятости, которые подразумевают конкретного работодателя, бессрочный трудовой договор, занятость в течение полного рабочего дня, чётко очерченные профессиональные позиции и перспективы карьерного продвижения. Преобладающая часть современного труда привязана к стабильным рабочим местам в цехах или офиcax, но глобальные технологические и экономические тенденции последних лет способствуют размыванию этой традиционной модели занятости. Сегмент нестандартной занятости постепенно растёт во всём мире, органично вписываясь в современный неолиберальный порядок с характерными для него рисками. Развитию нестандартных форм занятости уделяется большое внимание в современных концепциях постиндустриального общества, и они рассматриваются в общем контексте глобальной трансформации труда и формирования нового типа работника [Bell 1976; Castells 2010]. Насколько сфера труда будет эволюционировать к множественным формам гибкости, и останутся ли они маргинальной формой занятости, судить трудно. В настоящее время практически любой бизнес нуждается в работниках с долгосрочными контрактами, на них ориентированы программы стимулирования производительного труда - привлечения, мотивации, социальной поддержки. Направление инвестиций в работника, как указывается в теориях человеческого капитала и теориях фирм, является необходимым условием экономического роста фирмы, что может рассматриваться в качестве принципиального ограничения распространения нестандартной занятости, в том числе и заёмного труда.

Международная организация труда (МОТ) в отношении сегмента нестандартных рабочих мест оперирует понятием «прекаризованная занятость» (precarious employment) ${ }^{3}$, которое часто переводят нейтрально - как нестандартную занятость, но оно содержит негативные коннотации, поскольку обращает внимание прежде всего на социальные издержки гибкости трудового рынка. Общее понятие «прекаризация», возникшее в рамках критической социальной теории, получило распространение как часть проблематики, обсуждаемой в рамках нового левого и антиглобалистского движений ${ }^{4}$ Под этим по-

1 Заёмный труд - термин, принятый в русскоязычной литературе, является прямым переводом с нем. Leiharbeit. В англоязычной литературе применяются термины «лизинговый труд» или «агентский труд» (labor leasing, agency work). Мы будем использовать названные термины как синонимы.

2 К заёмным работникам не относятся люди творческих профессий, индустрии развлечений и спорта, работающие с агентами (актёры, музыканты, спортсмены и др.).

От лат. precarius - неустойчивый, нестабильный, шаткий.

4 Введение термина в научный оборот приписывается немецкому социологу Ульриху Беку (Ulrich Beck). 
нятием подразумевается процесс фундаментальных изменений условий существования людей в постфордистском обществе в сторону нестабильности, как в экзистенциальном, так и в экономическом смысле [Bourdieu 2003; Кастель 2009].

Поскольку в схеме заёмного труда наиболее ярким образом воплощается идея прекаризованной занятости (и работа - без гарантий, и ответственность работодателя не совсем ясна), проблема его распространения в социологии рассматривается в двух аспектах. Во-первых, в широкой социальной перспективе угрозы стабильности жизни и доходов работающего населения; во-вторых, более узко, как проблема трудовой дискриминации работников, занятых в этом секторе. Помимо отсутствия гарантий занятости и ограничения возможности пользоваться в полном объёме социальными льготами, предоставляемыми постоянным работникам, их уязвимое положение объясняется действием некоторых негативных экономических и социально-психологических факторов. Согласно ряду исследований, работники, занятые на условиях лизинга, отличаются повышенным уровнем стрессовых нагрузок из-за неопределённости во взаимоотношениях между ними и работодателем [Hall 2006], более низкой оплатой труда по сравнению с постоянным персоналом [Segal, Sullivan 1997], отсутствием профессиональной идентичности [Bujold, Fournier 2008], низким уровнем удовлетворённости работой [Aletraris 2010].

Считается, что агентская занятость является уделом маргинальных групп на рынке труда: работники вынуждены на неё соглашаться, поскольку не могут найти достойного места. В то же время труд по лизингу может быть благом для определённых групп трудоспособного населения, обеспечивая свободу выбора трудовой траектории, гибкость и мобильность на рынке труда [Morris, Vekker 2001]. Подобная неопределённость в отношении к заёмному труду существует во всём мире. Схемы предоставления работников в пользование другим организациям прямо противоречат положению Филадельфийской декларации МОТ (1944 г.) о том, что труд не является товаром. С данным обстоятельством связано отсутствие каких-либо единых рекомендаций по регулированию этой сферы, которые носили бы международный характер, и законодательство в отношении заёмного труда в разных странах характеризуется значительной дифференциацией ${ }^{5}$.

\section{Масштабы распространения заёмного труда и проблема его регулирования}

Заёмный труд, появившийся в середине 1970-х гг. как ответ на тенденции флексибилизации рынка труда, довольно быстро распространяется по миру. В течение последних 10 лет число агентских работников в мире выросло втрое, и сейчас, по данным Международной конфедерации частных агентств (International Confederation of Private Employment Agencies, CIETT) занятости, их около 10 млн, или $1-5 \%$ занятого населения в тех странах, где применяется заёмный труд. Абсолютным лидером в его применении являются США, где более двух миллионов заёмных работников, а в Европе лидируют Великобритания и Германия [The Agency Work Industry... 2011].

В России начало бизнеса по предоставлению услуг заёмного труда относится к концу 1990-х гг., когда кризис вынудил предпринимателей минимизировать расходы на персонал. Нынешние масштабы распространения этого явления точно не известны. Согласно данным обследования российских предприятий, только 2,4\% из них применяют заёмный труд, но если применяют, то с размахом: на таких предприятиях до четверти работников находится в лизинге [Смирных 2010: 15]. По различным экспертным оценкам, численность работников, нанятых агентствами для работы на условиях заёмного труда, со-

5 Конвенция № 181 МОТ «О частных агентствах занятости» (1997 г.) признала законность услуги по предоставлению работников в распоряжение третьей стороне. Но формирование правового статуса частных агентств занятости и системы защиты заёмных работников отнесены на национальный уровень. Директива Европейского Союза о труде в агентствах временной занятости (№ 2008/104/ЕС, 2008 г.) также не регулирует права и обязанности субъектов отношений по заёмному труду, делегируя это регулирование на национальный уровень социального партнёрства. 
ставляет 70-300 тыс. человек, или 0,1-0,4\% занятого населения [Гермерсхаузен 2010; Горохова 2012]. Согласно российской статистике, агентские работники входят в состав занятых на непостоянной основе, общая численность которых в 2011 г. была около 5,5 млн человек, или 8,3\% занятого населения [Обследование населения... 2011]. При этом число занятых в неформальном секторе экономики, где изначально нет никаких трудовых гарантий, намного выше: в июне 2012 г. в неформальном секторе работали около 14 млн человек, или 19,5\% занятого населения [Обследование населения... 2012]. И число таких работников только увеличивается (по сравнению с 2008 г. — в 1,5 раза). Учитывая эти размеры прекаризованной занятости, заёмный труд в масштабах российской экономики, даже если придерживаться максимальных цифр, приводимых экспертами, — капля в море.

Тем не менее практики использования заёмного труда в России опережают формирование необходимой правовой базы. Участники рынка лизинга персонала вынуждены использовать вместо контрактов о предоставлении персонала всевозможные юридические субституты, что создаёт почву для злоупотреблений [Капелюшников 2011]. Вопрос введения в России законодательного регулирования заёмного труда и условий этого регулирования активно обсуждается. Аргументы в пользу заёмного труда носят характер в основном экономический: простота найма и увольнения позволяет компаниям гибко реагировать на колебания спроса, что, в конечном счёте, плюс для российской экономики. Аргументы против заёмного труда имеют характер в основном социальный: распространение нестандартных рабочих мест снижает стабильность занятости, угрожает всей сложившейся системе трудовых отношений. Однако содержание большинства публикаций свидетельствует о недостаточности систематизированного знания не только о природе новых трудовых отношений, но и о практиках их применения. Имеющиеся сведения являются разрозненными, недостаток научных понятий замещается публицистическими метафорами типа «проституция в экономике», «торговля людьми» или, наоборот, «передовая форма трудовых отношений» и т. д. Это связано не только с привычным уже идеологическим противостоянием, но и с отсутствием серьёзного анализа российского опыта: практически нет сведений о самих работниках, занятых в этом секторе (кто они? почему соглашаются на такую занятость? каково их положение на предприятии? и т. д.). Данная работа, надеюсь, отчасти позволит заполнить этот пробел, поскольку в ней предлагается своего рода социальный портрет российских заёмных работников и раскрываются наиболее важные моменты, характеризующие заёмную рабочую силу: социальный состав, мотивы трудоустройства, отношение работников к агентской занятости, оценка условий труда, защищённость труда и удовлетворённость работой. Подчеркнём, что задача рассмотрения возможных плюсов и минусов заёмного труда для всех сторон социально-трудовых отношений, в том числе с точки зрения угрозы распространения прекаризованной занятости, не ставилась. В фокусе анализа находится только один, но, пожалуй, ключевой аспект для определения политики в отношении лизинга персонала — мнения самих работников.

Эмпирическую базу составили данные первого масштабного опроса российских работников, занятых по схеме заёмного труда ${ }^{6}$. Реализованная выборка охватывает тот сегмент рынка лизинга персонала, который представлен крупнейшими агентствами-провайдерами, занимающими, по оценкам экспертов, не менее половины этого рынка. Такая локализация выборки может рассматриваться как ограничение данных, поскольку помимо агентств, принявших участие в исследовании, рынок включает множество мелких операторов, чьи практики пока остаются «за кадром». Однако остальные страны имеют схожие проблемы с измерением и описанием заёмной рабочей силы. Организация экономического сотрудничества и развития (ОЭСР), МОТ и другие подобные структуры не производят сопоставимые данные по распространённости заёмного труда и по социальному составу работников, занятых в этом секторе, поскольку соответствующая информация не собирается на регулярной основе. Некоторую информацию

6 Опрос проведён «Левада-Центром» по заказу НИУ ВШЭ в рамках «Стратегии-2020» (январь 2012 г.). Были опрошены заёмные работники, занятые в агентствах Kelly Services, Adecco и Ancor в городах: Москва, Санкт- Петербург, Пермь, Ростов-на-Дону, Тула, Липецк, Иваново. Поскольку параметры генеральной совокупности неизвестны, применялся дизайн так называемой «удобной» выборки (convenient sample). В указанных агентствах опрашивались все заёмные работники, которые согласились ответить на вопросы. Объём выборки - 1012 человек. 
предоставляют сами агентства, в частности в отчёте Международной ассоциации частных агентств занятости приведены сравнительные характеристики заёмных работников 28 стран [The Agency Work Industry... 2011]. Поскольку наша выборка построена на схожих принципах, мы считаем возможным провести ряд сопоставлений с этими данными.

\section{Социальный состав заёмных работников}

По основным социальным параметрам (пол, возраст, образование) состав российских заёмных работников имеет черты как схожие, так и отличные по отношению к характеристикам их коллег в других странах.

Соотношение мужчин и женщин в составе агентских работников различается по странам, но в большинстве европейских стран это преимущественно мужской тип занятости. Доля женщин среди заёмных работников составляет 20-30\%. Наиболее феминизирован этот сектор в Финляндии, где женщины в составе заёмных работников составляют $66 \%$. Россия перекрывает этот рекорд с лихвой: доля женщин среди заёмных работников составила в стране $72 \%$. Чем это можно объяснить? Гендерный состав заёмных работников обычно связывают с национальными особенностями отраслевой структуры рынка заёмного труда. В странах, где на этом рынке велика доля сектора услуг, больше женщин, а на рынках, где преобладает промышленный сектор, работает больше мужчин. В нашей выборке сфера услуг и промышленность представлены примерно в равных долях: 44\% рабочих мест на рынке лизинга персонала предлагаются промышленными предприятиями, 56\% - предприятиями сферы услуг. Однако значительная часть рабочих мест промышленного сектора в российском контексте предстают типично «женскими» (упаковщицы, сортировщицы, расфасовщицы и проч.). Поэтому гендерный дисбаланс в составе российских заёмных работников скорее связан с фундаментальными проблемами гендерной сегрегации рынка труда, чем с чрезмерной представленностью женщин в рискованных формах занятости. Отметим, что в России доля занятых по всем видам временных договоров среди женщин существенно меньше, чем среди мужчин (6,8\% против 11,5\%), в то время как в странах объединённой Европы картина обратная: доля занятых по временным контрактам выше среди женщин (14,6\% против 12,8\%) [Щербакова 2008; Обследование населения... 2011].

Как и в большинстве стран, агентская занятость в России представлена в основном работниками молодого возраста: 59\% участников опроса находятся в возрасте до 30 лет, 31\% — в возрасте 31-45 лет, и только $10 \%$ составляют работники старше 45 лет. Средний возраст российского заёмного работника - 31 год, но возрастной состав концентрируется среди 23-26-летних - как правило, это возраст окончания профессионального образования и первого выхода на рынок труда.

Преобладание в составе заёмной рабочей силы молодых специалистов подтверждается высоким уровнем образования этой группь занятых, что является главной отличительной чертой российской заёмной рабочей сильл: 51\% участников опроса имеют высшее и незаконченное высшее образование; $25 \%$ - среднее профессиональное образование. Доля людей с высшим и средним профессиональным образованием среди заёмных работников даже существенно (на 20\%) превышает соответствующую долю среди всего российского занятого населения [Обследование населения... 2011]. Ещё более отчётливо эта специфика проявляется в международном сопоставлении. В отличие от России в большинстве стран заёмные работники имеют относительно низкий уровень образования. В среднем (по всем странам) 51\% таких работников закончили только среднюю школу, а 24\% не имеют даже среднего образования.

Очевидно, что основная часть заёмной рабочей силы рекрутируется из недавних выпускников профессиональных учебных заведений ${ }^{7}$ конкурентоспособность которых на рынке труда ограничена из-за

7 В составе заёмных работников $13 \%$ студентов. 
отсутствия опыта работы (54\% участников опроса имеют трудовой стаж менее двух лет; для 18\% это первое трудоустройство). Отметим, что лизинговый труд не стал распространённой формой занятости для других «проблемных» групп на рынке труда, например, для людей пенсионного возраста (их доля в составе заёмной рабочей силы составляет $2 \%$ ).

\section{Мотивы трудоустройства и отношение к агентской занятости}

Одним из аргументов в пользу заёмного труда является тезис о его пользе в преодолении безработицы, в содействии трудоустройству граждан, не нашедших постоянную работу, а также в предоставлении работы тем людям, которые по каким-либо причинам не желают трудиться на условиях стандартной занятости [Пеннел 2012]. Важными характеристиками рекрутируемых агентствами работников поэтому являются наличие или отсутствие у них работы перед поступлением в агентство и мотивы выбора такого трудоустройства.

Согласно данным опроса, непосредственно перед трудоустройством в агентство 45\% участников опроса не имели работы и искали работу, то есть были безработными ${ }^{8}$ (см. рис. 1).

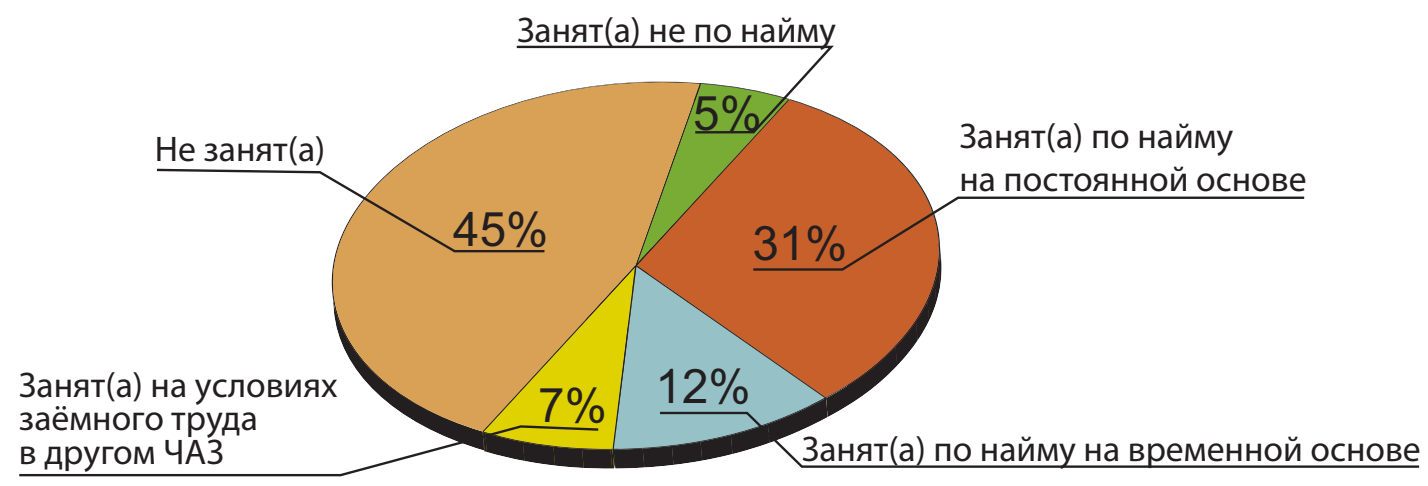

Рис. 1. Позиция на рынке труда перед трудоустройством в частное агентство занятости (ЧАЗ)

Тезис о содействии в преодолении безработицы в значительной степени подтверждается, что важно, если учесть преимущественно молодёжный состав заёмной рабочей силы. Известно, что уровень безработицы среди молодёжи выше, чем в старших возрастах. В 2012 г. уровень безработицы среди молодежи в возрасте 15-24 лет составил 15,8\%, что в четыре раза выше аналогичного показателя среди взрослого населения [Занятость и безработица... 2012]. Из остальных участников опроса, располагавших на момент поступления в агентство какой-либо работой, около $30 \%$ имели постоянную занятость и около 20\% - временную, в том числе и в качестве заёмных работников. Каждый десятый был занят неофициально.

Доля людей, для которых были изначально желательны и приемлемы нестандартные условия занятости, невелика: только 8\% участников опроса искали временную или неполную занятость, и ещё примерно столько же были согласны на любую работу. Большинство обращений в агентства оказались связаны все-таки с поиском постоянного трудоустройства (см. рис. 2).

Особую группу составляют так называемые жертвы аутстаффинга9. Каждый пятый участник опроса работу не искал и даже не менял, а был выведен работодателем за рамки штата и передан лизинговому

8 Средняя продолжительность безработицы небольшая - около двух месяцев. Только 6\% находились в состоянии длительной безработицы (более полугода).

9 Аутстаффинг (от англ. out — «вне» и staff — «штат») — вывод сотрудников за штат компании-заказчика и оформление его в штат компании-подрядчика, при этом сотрудник продолжает работать на прежнем месте и выполнять свои прежние обязанности, но обязанности работодателя по отношению к нему выполняет уже компания-подрядчик. 
агентству. Есть также небольшая часть соискателей работы, которые при трудоустройстве в компанию были направлены в агентство работодателем. Об этом участники опроса сообщили, самостоятельно дополнив ответ на вопрос о причине обращения в агентство: «сюда устроила компания, на которую я работаю», «меня направил работодатель, как и всех остальных», «такова кадровая политика моего работодателя», «такая форма трудоустройства предусмотрена в нашей компании» и проч.

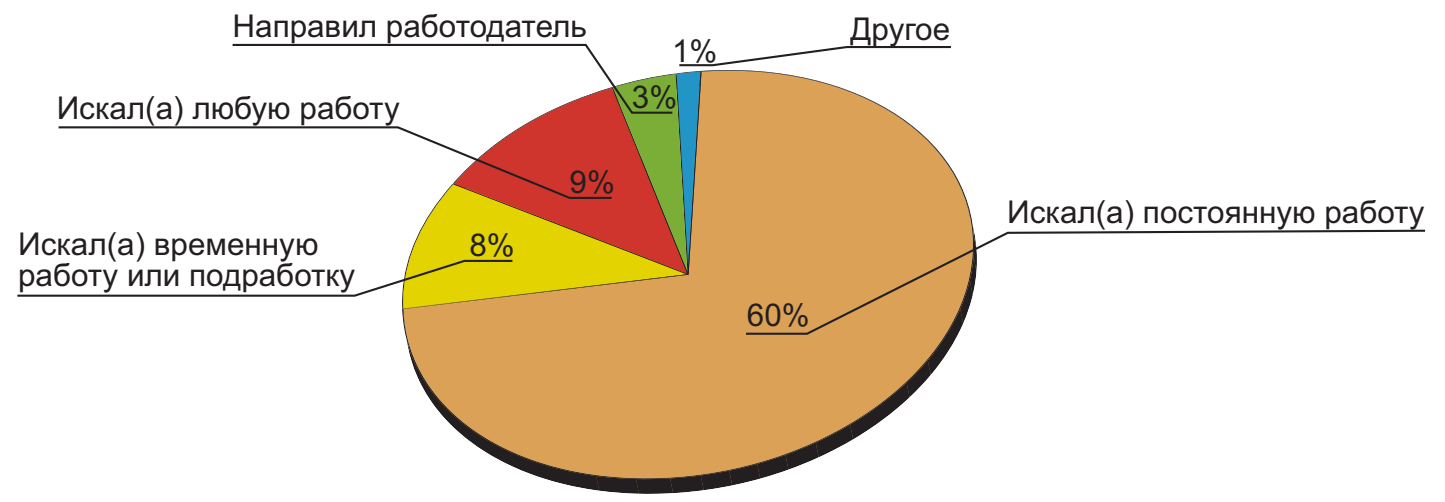

Рис. 2. Причины обращения в частное агентство занятости (ЧАЗ)

При отсутствии выраженного стремления к гибким формам занятости у основной части соискателей рабочих мест они соглашаются на заёмный труд в связи с разными другими обстоятельствами. Наиболее часто указывались две группы мотивов. Во-первых, оказалось, что для многих работников, участвовавших в опросе, способ оформления трудовых отношений не имеет особого значения; главное, чтобы устраивала сама работа (см. рис. 3). Во-вторых, распространено представление о том, что заёмный труд - ступенька к устойчивой занятости: работа по временным проектам в привлекательной компании даёт возможность «показать себя» и получить впоследствии постоянное рабочее место. Для молодёжи, находящейся на старте своей трудовой карьеры, это также возможность приобрести опыт работы в разных компаниях, инвестировать в свой человеческий капитал. Для значительной части участников опроса агентский труд имеет вынужденный характер, связанный с необходимостью найти хотя бы какую-то занятость.

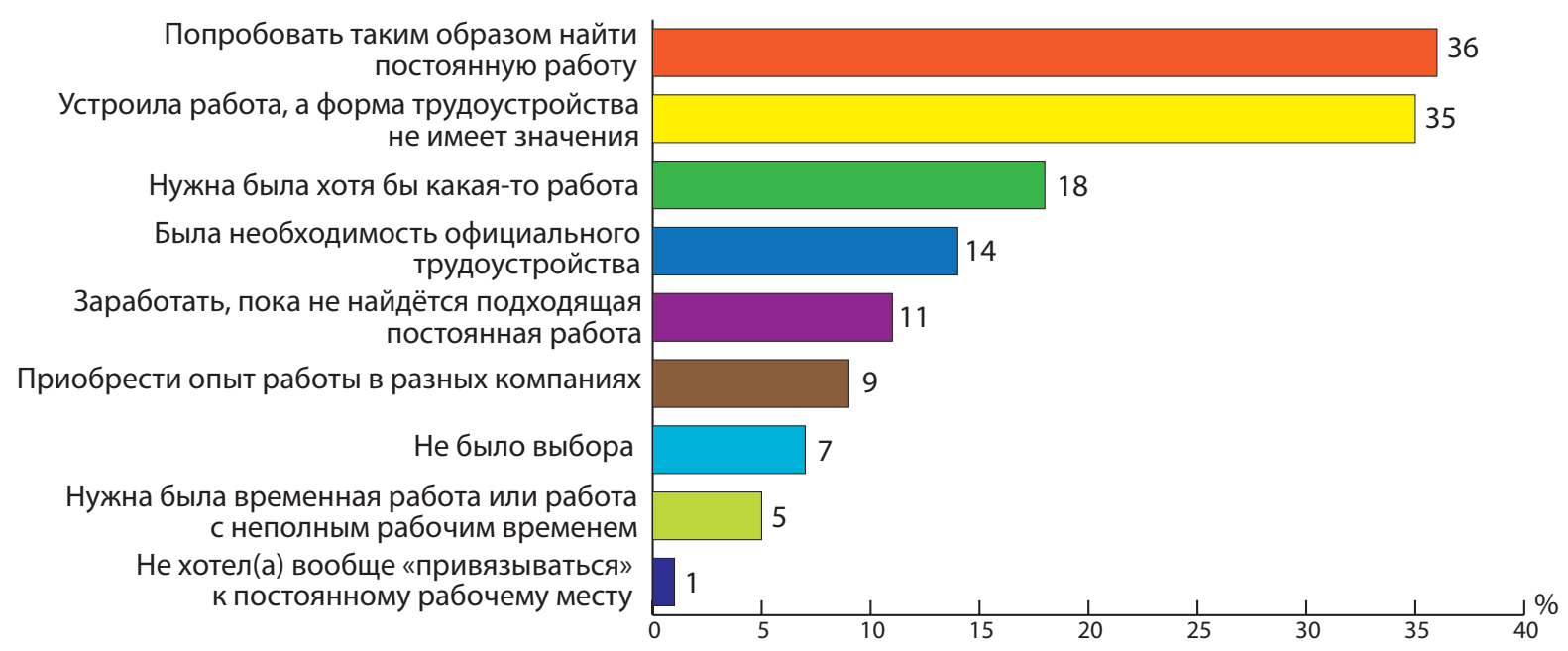

Рис. 3. Причины трудоустройства в частное агентство занятости (ЧАЗ)

Только 10 человек отметили в качестве причины трудоустройства в агентство принципиальный отказ от постоянной занятости («не хотел вообще “привязываться” к постоянному рабочему месту»). В других странах поиск гибкой занятости в качестве баланса между частной жизнью и работой (work in a flexible way) является важным мотивом выбора агентской занятости, например в Японии и США на него указывают более 40\% агентских работников [The Agency Work Industry... 2011]. 
Оценка работниками позитивных и негативных сторон агентской занятости не принесла неожиданностей: работа на условиях заёмного труда привлекательна прежде всего возможностью официальной занятости и стабильностью получения заработной платы (см. рис. 4). Тот факт, что агентства предлагают хотя и временное, но официальное трудоустройство, приобретает в российских условиях особое значение. Среди недостатков лидируют проблемы низкой социальной защищённости: отсутствие гарантий занятости и социальных льгот, связанных с постоянным рабочим местом (см. рис. 5).

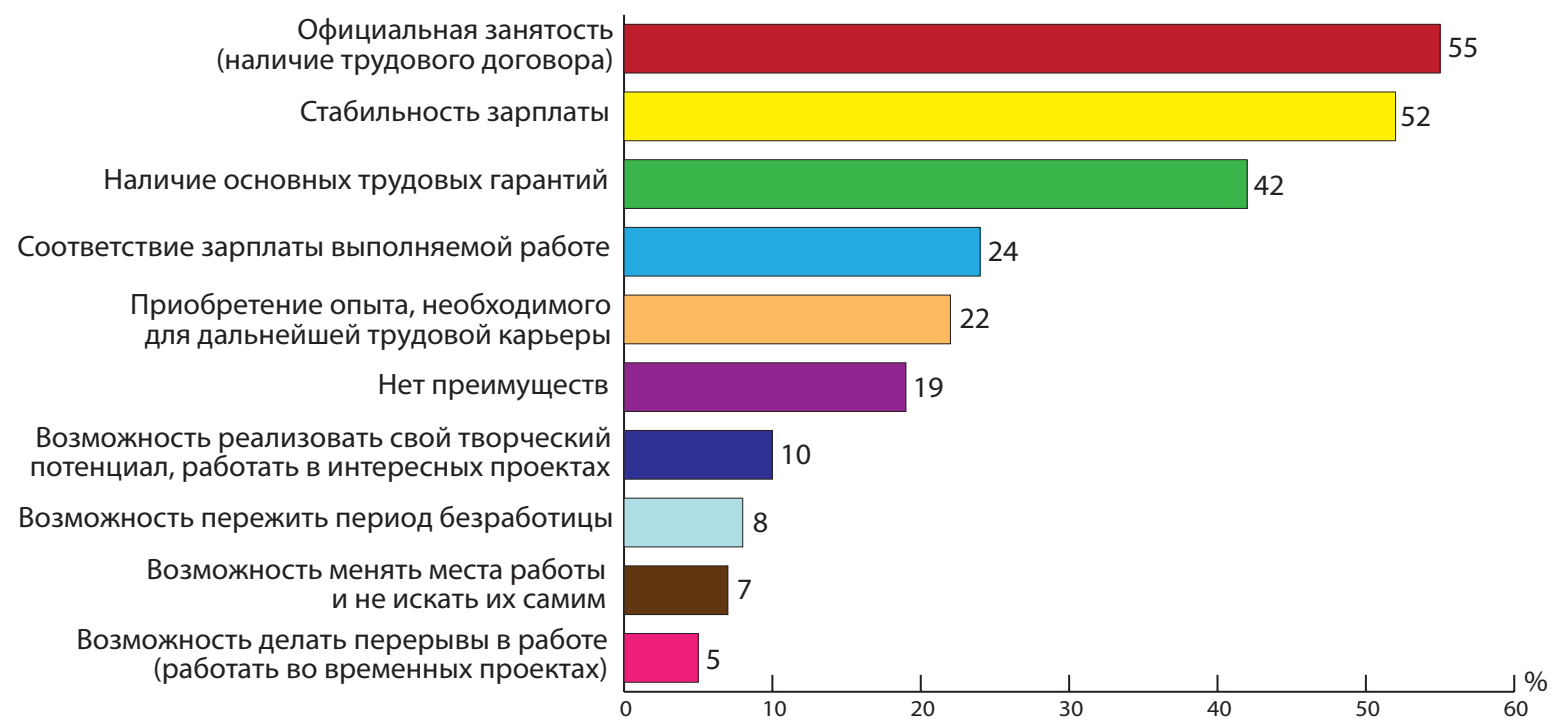

Рис. 4. Основные достоинства агентской занятости

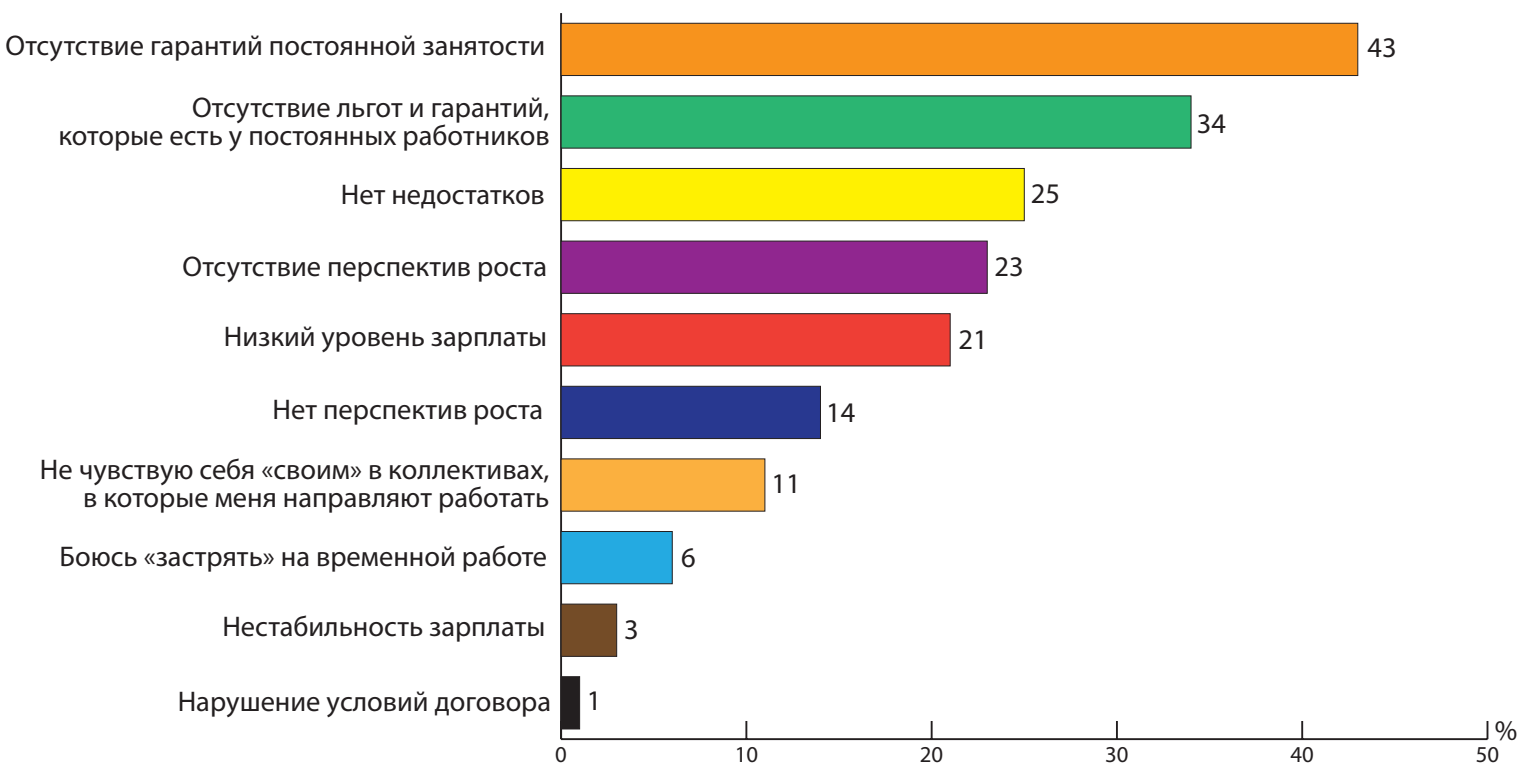

Рис. 5. Основные недостатки агентской занятости

Факторный анализ на основе набора вопросов о достоинствах и недостатках заёмного труда и дальнейшая обработка его результатов позволили выявить некоторые общие представления работников о такой форме занятости и оценить их распространённость ${ }^{10}$. Шесть выделенных факторов структурируют эти представления следующим образом:

10 Полученные шесть факторов в сумме объясняют 57,6\% дисперсии. Для определения распространённости тех или иных представлений каждому респонденту были приписаны доминирующие представления (максимальное значение соответствующей факторной переменной). 
— «Надёжная работа»: легальная занятость с заключением трудового договора, стабильной заработной платой и наличием базовых социальных гарантий. Такое представление характерно для 10\% респондентов, ответивших на соответствующие вопросы;

— «Работа без гарантий»: нет дополнительных социальных льгот и гарантий продления контракта $(10 \%)$;

- «Бесперспективная работа»: нет возможности карьерного роста и повышения квалификации; работник не становится «своим» в коллективе и подвергается опасности «застрять» на временной работе (11\%);

— «Мобильная работа»: современный тип занятости, который даёт возможность делать перерывы в работе, менять компании или заработать в период безработицы (10\%);

— «Справедливо оплачиваемая работа»: обеспечивает соответствие зарплаты выполняемой работе $(6 \%)$;

— «Незащищённая работа»: чреватость такой формы занятости невыполнением условий договора и нестабильностью зарплаты (4\%).

При всей противоречивости структура представлений об агентской занятости отражает появление разных запросов в сфере труда, в том числе и запрос на гибкую занятость, даже если это временный, а не долгосрочный жизненный проект. Добавим, что у половины участников опроса нет чётких представлений о том, чем плоха или хороша такая работа. Люди просто работают...

\section{Защищённость и трудовые отношения}

Одной из ключевых проблем защищённости работников в условиях заёмного труда является вопрос о типе договора, который заключается между работником и агентством. Трудовые договоры, согласно результатам опроса, заключены у 78\% заёмных работников.

Это важно, поскольку договор, являясь основным институтом трудового права в России, юридически закрепляет вступление в трудовые отношения, определяет содержание рабочих функций и регулирует взаимоотношения с работодателем. Оформленные должным образом трудовые отношения у большинства заёмных работников означают, что основные российские провайдеры лизинга персонала сами уже являются крупными работодателями, которые обязаны обеспечить базовые трудовые гарантии: выплаты по обязательному социальному страхованию, оплачиваемые отпуска и оплату временной нетрудоспособности. Данные опроса свидетельствуют о том, что агентства, принявшие участие в исследовании, выполняют свои социальные обязательства в отношении работников исправно: 98\% работников, оформленных по трудовому договору, предоставлялись оплачиваемые отпуска; 97\% указали на наличие оплаты временной нетрудоспособности.

В 60\% случаев договоры носят характер временных соглашений, в основном — на срок проекта (см. рис. 7). Но срок действия трудового договора (постоянного или временного) в этом плане значения не имеет, поскольку по российскому законодательству временные работники пользуются основными трудовыми гарантиями наравне с постоянными.

Примерно каждый пятый работник занят на условиях подряда (гражданско-правовые договоры). В отличие от трудового договора гражданско-правовой договор не даёт гарантий, предусмотренных Трудовым кодексом (ТК) РФ, а придаёт работнику юридический статус самостоятельно занятого подряд- 
чика. Проблема заключается в том, что большинство заёмных работников, оформленных на условиях подряда, работают в агентстве длительное время (средний стаж работы в агентствах примерно такой же, как и у тех заёмных работников, с которыми оформлены трудовые договоры, - три года). По сути, они являются не подрядчиками, а наёмными (хотя и посредством лизинга) работниками, исключёнными из системы социальной защиты работающего населения. Это не только существенно ухудшает их положение, но и негативно влияет на имидж лизинговых агентств.

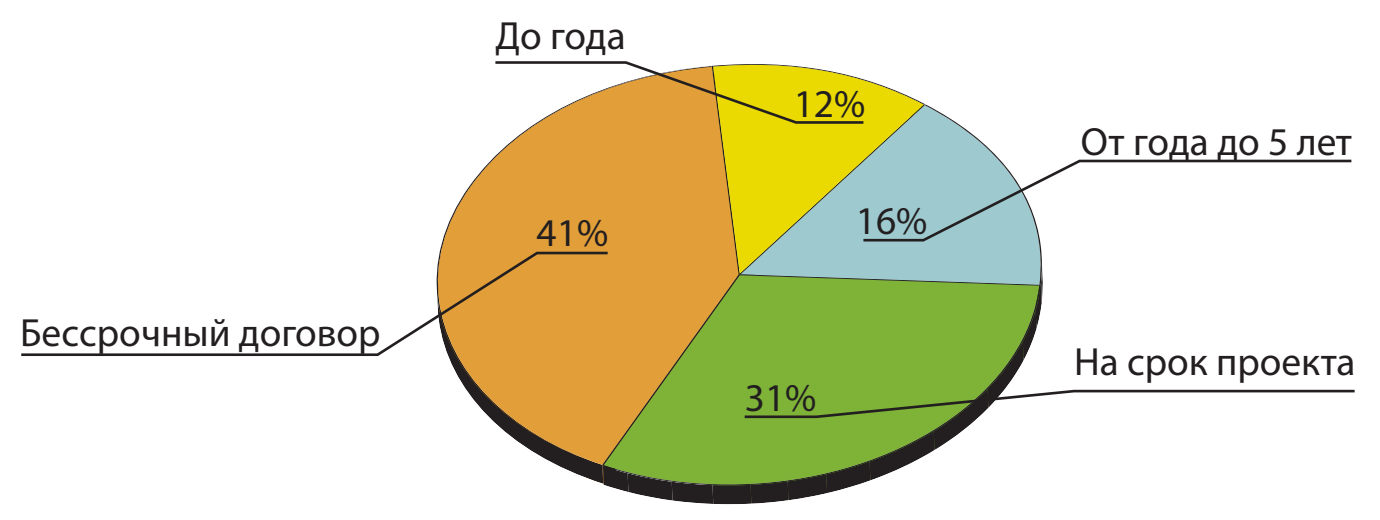

Рис. 6. Срок договора с частным агентством занятости (ЧАЗ)

Помимо социальных гарантий, важным показателем состояния трудовых отношений является уровень конфликтности. В агентствах он невысокий. Доля работников, у которых возникали конфликтные ситуации при взаимодействии с агентством, составляет 8\%. Конфликты, как правило, вызваны неудовлетворительным состоянием документооборота и бухгалтерии: задержки или неправильное начисление зарплаты (потери рабочих смен) и социальных выплат (отпускные, больничные), неоправданно длительное оформление документов (на кредит, загранпаспорт и проч.). О конфликтных ситуациях, которые возникали при исполнении непосредственных трудовых обязанностей на предприятияхзаказчиках, сообщили 5\% агентских работников. Чаще всего они связаны с проблемами отношений с постоянным персоналом: «конфликты с персоналом компании, куда направляют»; «возникали в вафельном цехе, от “постоянщиков"»; «отсутствие доброжелательности со стороны некоторых бригадиров или старших по участку»; «техническое задание на месте оказалось несколько другим, это была вина работодателя, он небрежно объяснил агентству, что ему требуется»; «меня лишали перерыва, мотивируя это тем, что производственный план не выполняется».

Возникающие конфликты носят индивидуальный характер. В агентствах лизинга персонала профсоюзов нет, поэтому коллективная защита и коллективные договорённости на работников не распространяются. Впрочем, как и у большинства россиян, у агентских работников большого доверия институт профсоюзов не вызывает. Тем не менее $36 \%$ опрошенных верят в профсоюзную защиту и готовы вступить в профсоюз. В условиях нестабильности работы и статуса занятости агентских работников крайне важно, чтобы профсоюзы могли их консультировать и отслеживать социальную ответственность агентств перед работниками. Отметим, что некоторые работники в своих претензиях к агентству демонстрируют непонимание специфики своих трудовых отношений: «нет подарков на Новый год детям, нет премий, как на фабрике, а работаем все одинаково», «ужасно, что смена должности происходит через увольнение», «нет льгот» и проч. Очевидно, что регулирование заёмного труда должно предусматривать распространение соглашений с профсоюзами, как это делается в некоторых других странах [Садовая 2009]. 


\section{Структура рабочих мест и условия труда}

Заёмный труд, как свидетельствуют данные исследования, по большей части является областью труда, не требующего высокой квалификации. В должностной структуре доля специалистов составляет менее четверти, а на руководящие должности приходится 4\% (см. рис. 7). Основную долю рабочих мест составляют рабочие специальности и обслуживающий персонал сервисной сферы (см. рис. 8).

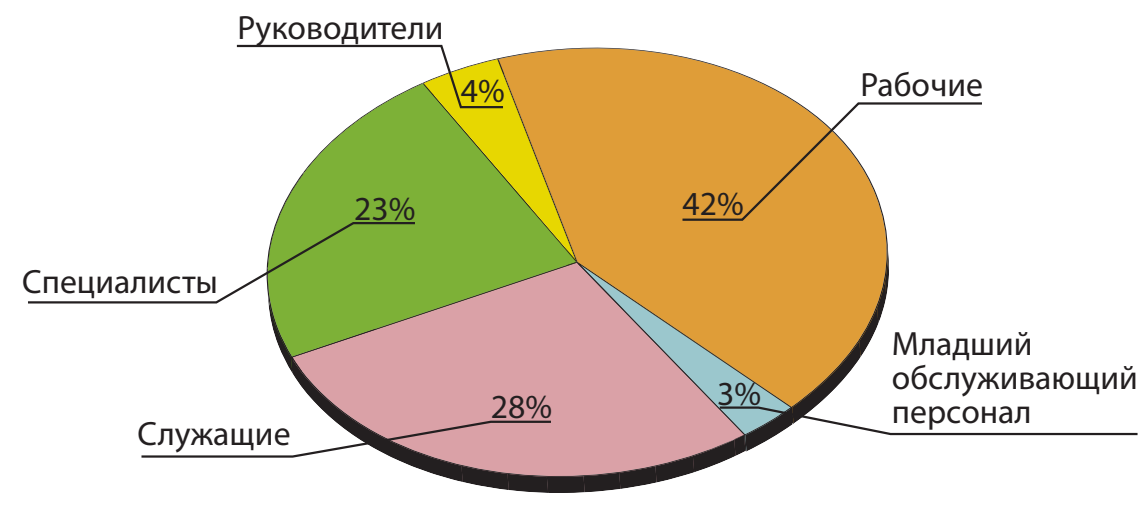

Рис. 7. Должностная структура заёмных работников

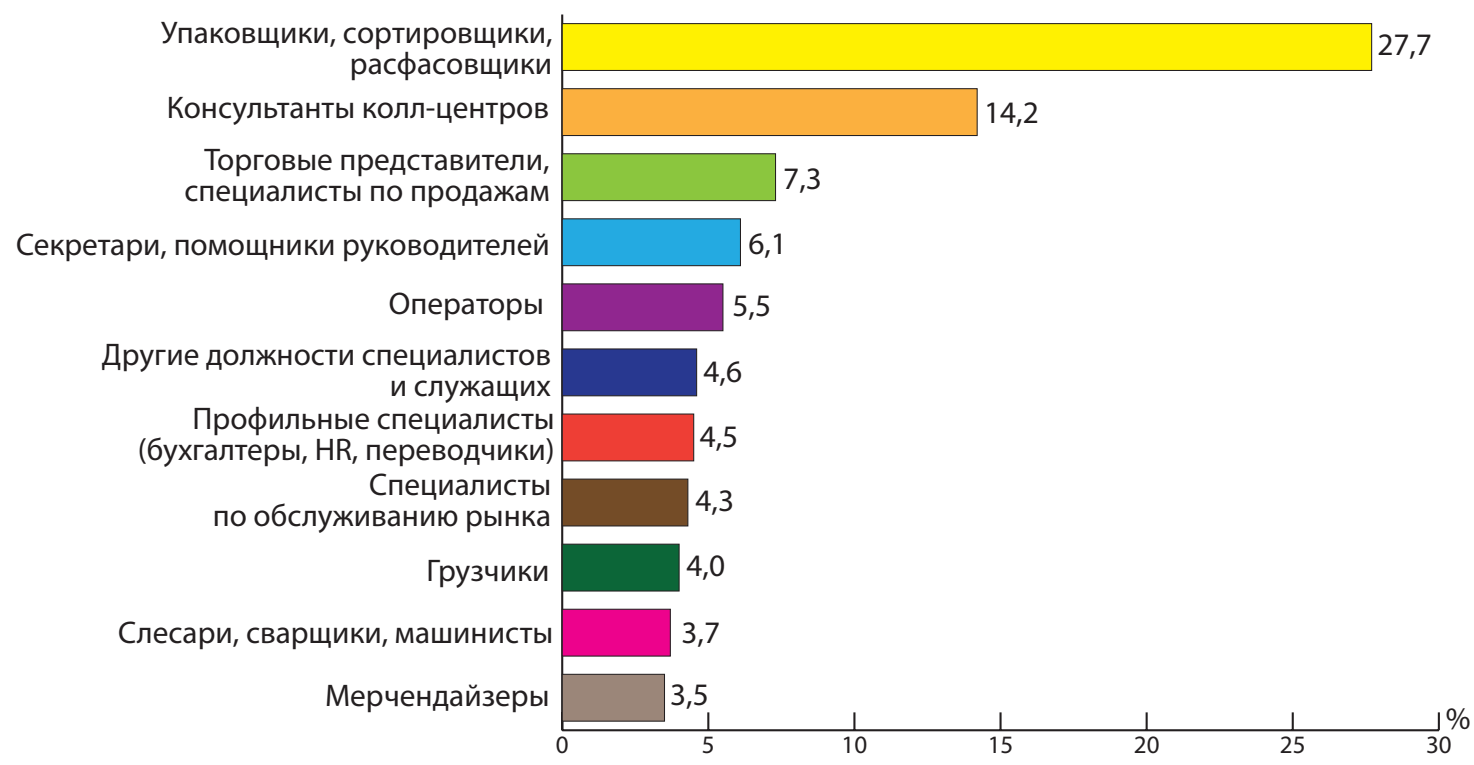

Рис. 8. Структура рабочих мест (должность, рабочая специальность)

Представленная на рисисунках 7 и 8 конфигурация не соответствует высокому уровню образования работников, занятых на условиях лизинга: две трети из числа имеющих высшее и среднее профессиональное образование работают не по специальности. Впрочем, эта проблема характерна для всего рынка труда: если верить статистике, 60\% россиян работают не по специальности [Итоги... 2012]. Несмотря на несоответствие работы полученной специальности, только около трети работников указали, что их уровень квалификации выше, чем нужно для этой работы. Возможно, большинство недавних выпускников считают для себя нормальным начинать с низких позиций, осваивая новые компетенции, набирая опыт и имея возможность заработать.

Характеристики работы были представлены в исследовании оценками уровня оплаты, интенсивности и условий труда. 
Наиболее важным для понимания реального положения заёмных работников является вопрос оплаты труда. Дизайн исследования не предусматривал возможности сопоставления заработков по профессиям и должностям занятых на условиях лизинга и постоянных работников одних и тех же предприятий, что могло бы считаться корректным сравнением ${ }^{11}$. В самом общем виде можно попробовать соотнести средний размер заработной платы заёмных работников с тем же показателем по России (в 2011 г. он составлял 23693 руб.). Средний заработок заёмных работников за тот же период был несколько ниже 21055 руб. Но прерывность занятости, составляющая специфику работы по проектам, влечёт за собой общее сокращение фактически отработанных дней ${ }^{12}$. При всей приблизительности таких вычислений в пересчёте на среднечасовую заработную плату картина меняется. В среднем за час работы заёмные работники получали 297 руб., что существенно выше аналогичного среднероссийского показателя, который за тот же период времени составлял 150,9 руб. [Труд и занятость... 2011: 417]. Возможно, что повышенная часовая ставка служит компенсацией предприятий-пользователей за срочность предоставления необходимого персонала.

В качестве ещё одного показателя выступает субъективная оценка размера заработка. Согласно данным недавнего обследования Росстата, только четверть работающих россиян удовлетворены оплатой своего труда [Итоги... 2012]. Показатель удовлетворённости зарплатой заёмных работников выглядит более позитивно: 60\% из них удовлетворены (или скорее удовлетворены) своим заработком.

Ещё одним положительным моментом, связанным с оплатой труда заёмных работников, является относительная стабильность заработка. Несмотря на проектный характер занятости, для 80\% опрошенных размер заработка не менялся в течение последнего года или менялся незначительно.

Помимо оплаты труда, в оценке общих условий занятости большое значение имеют интенсивность труда и условия, в которых трудятся заёмные работники. При неопределённости контракта повышенная интенсивность труда может провоцировать у работников нервное напряжение и стрессы. Действительно, примерно треть участников опроса указали на высокую степень загрузки, а 5\% - на чрезмерную («очень загружен, работаю на пределе своих сил»). Конечно, этот показатель весьма субъективен, тем не менее основная часть заёмных работников считают свою загруженность нормальной (см. рис. 9).

Судя по ответам, наиболее интенсивно трудятся руководители, а наименее - рабочие. Но средняя продолжительность рабочей недели у рабочих выше - 44 часа. Основной вопрос, который возникает в связи с этим: оплачивается ли сверхурочная работа? Отвечая на этот вопрос, подавляющее большинство рабочих (81\%), занятых сверхурочно, указали на наличие положенных компенсаций.

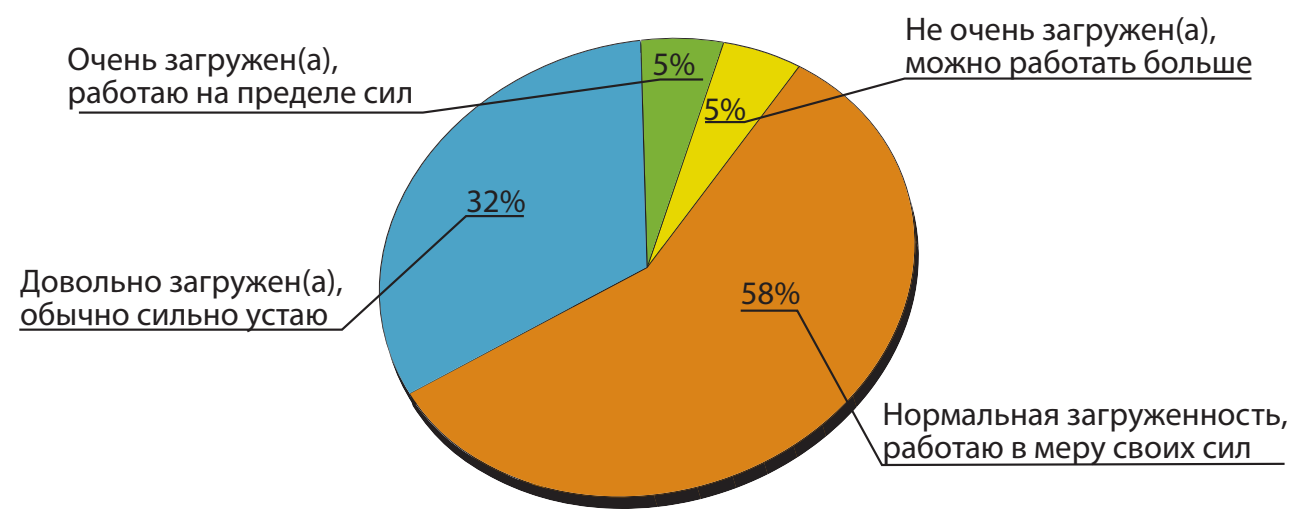

Рис. 9. Оценка загруженности на работе

11 Сравнение заработков постоянных и лизинговых работников не представляется возможным, в том числе и по причине отсутствия на исследованных предприятиях аналогичных штатных рабочих мест.

12 Среднее число отработанных дней в месяц у заёмных работников составляет 17,7. 
Проблема компенсаций возникает и при рассмотрении условий труда. Большинство заёмных работников считают условия труда нормальными (см. рис. 10). Из числа тех, кто оценил свои условия труда как неблагоприятные (вредные), 86\% указали, что получают за это компенсацию.

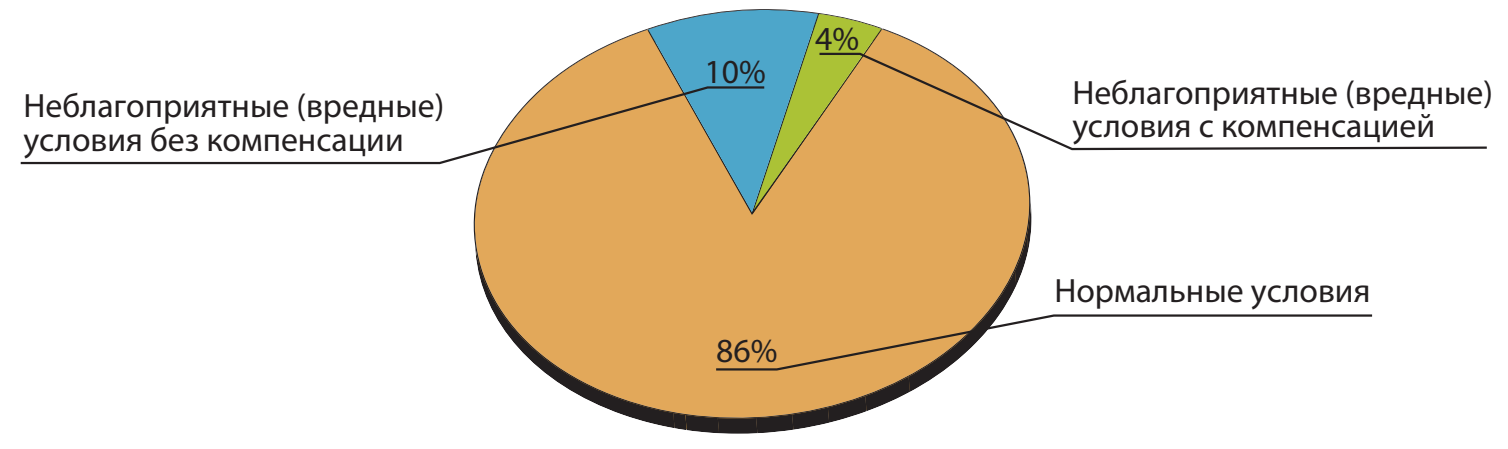

Рис. 10. Оценка условий труда

Общий уровень удовлетворённости работой довольно высокий: 79\% агентских работников устраивает их работа (сумма ответов «полностью устраивает» и «скорее устраивает»). Об отсутствии особых претензий к своей занятости свидетельствует и тот факт, что большинство работников (88\%) собираются продолжить сотрудничество с агентством в ближайшем будущем. Более того, четверть из них готовы к переезду в другой регион, если этого потребует работа на временных проектах.

Тем не менее агентская занятость для подавляющего числа работников носит характер временного жизненного проекта. В долгосрочной перспективе практически все (95\%) рассчитывают получить постоянную работу. Пока сложно судить о том, насколько оправданны эти ожидания, и будет ли заёмный труд связующим звеном между временной и постоянной занятостью. Средний стаж работы на условиях заёмного труда, по данным опроса, составляет 3,3 года; около 40\% участников опроса находятся в этом статусе более 3 лет, а у 5\% респондентов совокупный стаж работы в разных агентствах составляет уже более 10 лет.

\section{Регулирование заёмного труда: «запретить нельзя разрешить»}

Итак, нельзя сказать, что большинство заёмных работников стремились именно к такой занятости, но востребованность лизингового труда определённой частью трудоспособного населения, хотя и в качестве временного решения проблем на рынке труда, не подлежит сомнению. Обзор мнений заёмных работников об условиях их работы рисует картину не идеальную, но вряд ли более негативную, чем на российском рынке труда в целом. Отметим, что высокая доля позитивных оценок связана в том числе с преимущественно молодёжным составом участников опроса, для которых в большей степени, чем для представителей старших возрастных групп работников, свойственен оптимизм. Разумеется, нужно учитывать и то, что состав заёмной рабочей силы не ограничивается работниками, нанятыми крупными агентствами, принявшими участие в исследовании. Нельзя исключать существование недобросовестных практик со стороны других участников рынка. Но в таком случае необходимость регулирования новых форм трудовых отношений очевидна, иначе лизинг персонала будет продвигаться в тень, что приведёт только к ухудшению положения работников этого сектора.

Стабильность или изменчивость состава рабочих мест имеет решающее значение в качестве факторов, формирующих институты социально-трудовых отношений. Для поведения основных акторов этих отношений (государство, бизнес и профсоюзы) и содержания вырабатываемых ими правил важно, является ли рабочее место стабильным или нет, а также каковы масштабы нестабильной занятости. 
Динамику развития агентской занятости связывают с состоянием экономики: её рост наблюдается в неблагоприятной экономической ситуации, когда работодатели сокращают издержки на рабочую силу, a работники ищут средства к существованию [Golden, Appelbaum 1992]. Но для российского бизнеса на сегодняшний день основной причиной использования заёмного труда остаётся экономия издержек, а не адаптация к колебаниям спроса или прочие резоны [Смирных 2010: 24]. Без разумного регулирования риски превращения относительно гарантированных рабочих мест в негарантированные и незащищённые остаются поэтому высокими.

Современные работники получили связанные с работой права и льготы благодаря рабочему движению и трудовым отношениям, которые сложились в течение прошлого века. Соответственно введение норм, обеспечивающих институциональное разнообразие форм занятости, требует от социальных партнёров выработки симметричных мер компенсирования безопасности работников, занятых в этом секторе. Меры по предотвращению дискриминации и сокращению рисков заёмных работников должны быть приняты по двум основным направлениям. Во-первых, признание и введение государственного регулирования сферы заёмного труда. Международная практика демонстрирует множество примеров повышения гарантий заёмным работникам путём установления соответствующих норм в рамках национального законодательства: лицензирование и сертификация деятельности агентств, ограничение использования заёмного труда по определённым секторам или группам профессий, установление максимально допустимого времени использования заёмного труда и проч. [Смирных 2005; Садовая 2009]. Во-вторых, регулирование масштабов распространения заёмного труда через механизмы социального партнёрства на всех его уровнях. Этот путь, несомненно, более сложный, но потенциально более продуктивный, поскольку позволяет через переговорный процесс сохранять баланс между эффективностью бизнеса и защищённостью работников с учётом реального положения дел на предприятии или в отрасли. Сложность такой формы регулирования в современных условиях определяется как низким уровнем развития реального социального диалога между сторонами трудовых отношений, так и позицией профсоюзов, для которых вопрос стабильности рабочих мест является ключевым: «нестандартные» работники не входят в союз и не создают союзы, сокращая тем самым социальную базу профсоюзного движения. К представлению интересов разных типов работников, к действиям на новых рабочих местах и к функционированию в новых формах организации институт профсоюзов пока не приспособлен, поэтому законодательный запрет заёмного труда является для профсоюзов предпочтительным и наиболее простым способом решения проблемы. Но, учитывая многообразие и специфику запросов различных категорий занятых, такой запрет может противоречить потребностям тех самых работников, чьи интересы профсоюз призван представлять. Как говорил герой известного фильма ${ }^{13}$ : «Поверьте историку: осчастливить против воли нельзя». Остаётся искать компромиссы между интересами разных групп.

\section{Литература}

Гермерсхаузен М. 2010. Почему нельзя запрещзать кадровый аутсорсинг. URL: http://www.forbes.ru/ svoi-biznes-column/biznes-i-vlast/60350-pochemu-nelzya-zapreshchat-kadrovyi-autsorsing

Гимпельсон В., Капелюшников Р. 2005. Нестандартная занятость и российский рынок труда. Препринт WP3/2005/05. М.: Изд. дом Высшей школы экономики.

Горохова Е. 2012. Kelly Services: Заёмный труд. URL: http://www.rb.ru/inform/150307.html

Занятость и безработица в РФ. 2012. Федеральная служба государственной статистики. URL: http:// www.gks.ru/bgd/free/b04_03/IssWWW.exe/Stg/d04/180.htm

13 «Покровские ворота» (1982). 
Итоги Комплексного наблюдения условий жизни населения. 2012. Федеральная служба государственной статистики. URL: http://www.gks.ru/free_doc/new_site/population/urov/kn-ujn/tabl2.html

Капелюшников Р. 2011. Как оценивать жёсткость законодательной защиты занятости для России: комментарий. Препринт WP3/2011/02. М.: Изд. дом Высшей школы экономики.

Кастель Р. 2009. Метаморфозы сочиального вопроса. Хроника наёмного труда. СПб.: Алетейя.

О состоянии рынка труда в 2008-2010 гг. 2012. Федеральная служба государственной статистики. URL: http://2020strategy.ru/data

Обследование населения по проблемам занятости. 2011. Федеральная служба государственной статистики. URL: http://www.gks.ru/bgd/regl/b10_30/Main.htm

Обследование населения по проблемам занятости. 2012. Федеральная служба государственной статистики. URL: http://www.gks.ru/bgd/regl/b12_30/Main.htm

Пеннел Д. 2012. Вклад частных агентств занятости в развитие рынка труда. URL: http://2020strategy. $\mathrm{ru} / \mathrm{g} 7 /$ documents/32583189.html

Садовая Е. 2009. Некоторые тенденции изменения характера сочиильно-трудовых отношений в современных условиях. Социально-трудовые исследования. Вып. ХХІІ. М.: ИМЭМО РАН; 28-42.

Смирных Л. 2005. Заёмный труд: экономическая теория, опыт стран ЕС и России. М.: РЕЦЭП.

Смирных Л. 2010. Нестандартные трудовые договора: опыт использования предприятиями. Препринт WP15/2010/03. М.: Изд. дом Высшей школы экономики.

Труд и занятость в России. 2011. Статистический сборник. URL: http://www.gks.ru/wps/wcm/connect/ rosstat/rosstatsite/main/publishing/catalog/statisticCollections/doc_1139916801766

Щербакова Е. 2008. Занятость женщин Европь растёт, но пока остаётся заметно ниже, чем у мужчин. URL: http://demoscope.ru/weekly/2008/0349/barom04.php

Aletraris L. 2010. How Satisfied are They and Why? A Study of Job Satisfaction, Job Rewards, Gender and Temporary Agency Workers in Australia. Human Relations. 63 (8): 1129-1155.

Bell D. 1976. The Coming of Post-Industrial Society: A Venture in Social Forecasting. Harmondsworth: Penguim; Peregrine.

Bourdieu P. 2003. Counterfire: Against the Tyranny of the Market. New York: Verso.

Bujold C., Fournier G. 2008. Occupational Representations of Workers in Nonstandard and Precarious Work. Journal of Career Assessment. 16 (3): 339-359.

Castells M. 2010. The Information Age: Economy, Society and Culture. The Rise of the Network Society. Oxford: Blackwell. 
Golden L, Appelbuam E. 1992. What was Driving the 1982-1988 Boom in Temporary Employment? Preference of Workers or Decisions and Power of Employers. American Journal of Economics and Sociology. 51 (4): 473-493.

Hall R. 2006. Temporary Agency Work and HRM in Australia: «Cooperation, Specialization and Satisfaction for the Good of All?» Personnel Review. 35 (2): 158-174.

Morris M., Vekker A. 2001. An Alternative Look at Temporary Workers, Their Choices, and the Growth in Temporary Employment. Journal of Labor Research, Transaction Publishers. 22 (2): 373-390.

Segal L., Sullivan D. 1997. The Growth of Temporary Services Work. Journal of Economic Perspectives. 11: 117-136.

The Agency Work Industry Around the World. 2011. CIETT. URL: http://www.ciett.org 


\title{
НОВЫЕ ПЕРЕВОДЫ
}

\author{
Ф. Доббин
}

\section{Формирование промышленной политики: Соединённые Штаты, Великобритания и Франция в период становления железнодорожной отрасли ${ }^{1}$}

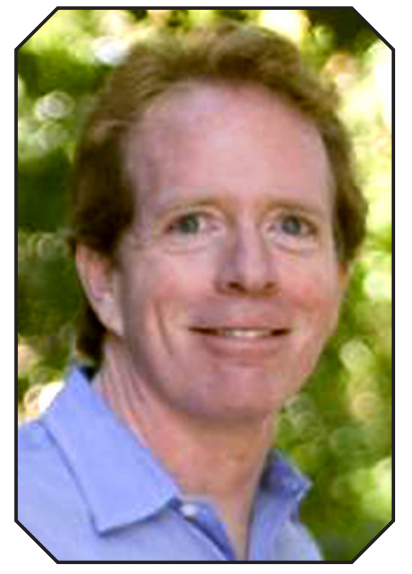

ДОББИН Фрэнк (Dobbin, Frank R.) профрессор фракультета социологии

Гарвардского

университета (Кембридж, США).

Email: frank_dobbin@ harvard.edu

Перевод с англ.

Екатерины

Головляницыной.
В США, во Франциии и в Великобритании проводится различная промышленная политика для достижения экономического роста. В книге Ф. Доббина представлено объяснение происхождения наблюдаемых различий на примере анализа эволючии государственного регулирования одного из передовых экономических секторов - железнодорожной отрасли. Автор бросает вызов традиционным взглядам, господствующим в экономической теории, политической науке и сочиологии, утверждая, что культурные смыслы играют важную роль в развитии рационализированных политических систем, служащих иелям экономического роста.

Журнал публикует первую главу книги Ф. Доббина — «Political Culture and Industrial Rationality» («Политическая культура и промьиленная рациональность»). В ней представлены теоретические рассуждения автора о причинах межстрановых различий в политике.

Ключевые слова: политическая культура; промышленная политика; институты; практики и смысл; политико-культурный подход; современное государство; железнодорожная отрасль.

\section{Политическая культура и промышленная рациональность}

\section{Введение}

B XIX веке каждое западное национальное государство выработало отчётливую стратегию управления промышленностью. Ведущие теории принятия политических решений не уделяют должного внимания происхождению этих стратегий, что в конечном счёте не позволяет им объяснить, почему стратегии управления промышленностью остаются неизменными, несмотря на революции, смену правящих режимов, войны и депрессии. Экономисты и сторонники функционального подхода, предполагающие, что выбор политики определяется законами экономической эффективности, не в си-

1 Доббин Ф. 2012 (готовится к изданию). Формирование промышленной политики: Соединённые Штаты, Великобритания и Франция в период становления железнодорожной отрасли. М.: Изд. дом ВШЭ (серия «Социальная теория»). Источник: Dobbin F. 1994. Forging Industrial Policy: The United States, Britain, and France in the Railway Age. Cambridge [England], NY: Cambridge University Press. - Здесь и далее примеч. ред. и перев. 
лах раскрыть причины того, почему стратегии разных наций не становятся похожими, приближаясь к некоей наиболее эффективной модели. Исследователи в области политической теории, считающие, что выбор политики отражает предпочтения властей предержащих, тоже не в состоянии объяснить, почему национальные стратегии промышленной политики остаются относительно неизменными даже при смене радикально различающихся идеологически режимов.

Исследователи истолковывают происхождение государственных стратегий политики в таких терминах как «традиция» и «наследие», однако большинство теоретиков предпочитают работать с поддающимися обобщению политическими и экономическими параметрами и не учитывают влияние национальных традиций. В результате в сравнительных исследованиях политики возникает прискорбный разрыв между теорией и эмпирическими результатами: теория подчёркивает роль универсальных политических и экономических сил, а эмпирические исследования, как правило, акцентируют внимание на влиянии традиций. Во многих работах поэтому теоретически значимые факторы помогают понять лишь крошечную часть различий между странами, а огромный неподдающийся объяснению остаток трактуется как эффект культуры и традиции. Я полагаю, что причину нежелания теоретического осмысления традиций следует искать в одном из постулатов современного мировоззрения, согласно которому уникальные традиции суть реликты прежней эпохи, обречённые на исчезновение под натиском логики и рассудка. Уверенность в том, что в наши дни выбор политики определяется универсальными законами интереса и рациональности, заложена в самую основу современного мировоззрения и не позволяет рассматривать что-либо связанное с культурой как двигатель политического выбора.

В этой книге я изучаю происхождение государственных стратегий промышленной политики, прослеживая эволюцию политики в железнодорожной сфере в США, во Франции и в Великобритании в 1825-1900 гг. Моя цель — дать теоретическое объяснение традициям, определяющим национальный характер политики. Обратиться к этой задаче меня побудили два обстоятельства теоретического характера. Во-первых, хотя различия между современными странами в организации хозяйства и экономической политики очень велики, и не похоже, будто они сокращаются, большинство исследователей готовы изучать что угодно, но только не процессы, в ходе которых возникают и воспроизводятся эти различия. Во-вторых, те немногочисленные теории, которые всё же берутся за истолкование межстрановых различий, обладают множеством недостатков. Объяснения, указывающие на несходство «национальных характеров», являются частным случаем редукционизма, так как сводят причины несходства в институтах разных стран к коллективным психологическим особенностям неясного происхождения. Неоинституционалистские (стейтистские) концепции политики подчёркивают роль структурной инерции, используя множество терминов со сходным смыслом, однако не могут установить причины инерционности институтов. Утверждение «институты продолжают существовать, потому что они институционализированы» не является объяснением - это лишь констатация. Я полагаю, что влияние традиций той или иной страны на принятие политических решений обусловлено их вкладом в коллективные представления о социальном порядке и инструментальной рациональности. В разных странах исторически сложились неоднородные представления о порядке и рациональности, и современные стратегии промышленной политики формируются вокруг этих представлений.

Мои рассуждения основаны на двух несложных эмпирических наблюдениях. Во-первых, на протяжении XIX века суверенные государства создавали институты для организации хозяйственной жизни по подобию институтов, организующих политическую жизнь. В политике США суверенитетом наделялись независимые местные правительства, подчиняющиеся относительно слабой федеральной власти (представленной преимущественно судебной системой). В промышленной политике хозяйственная независимость в первую очередь предоставлялась правительствам местных сообществ, которые активно содействовали экономическому развитию, и во вторую - системе федерального арбитража, что позволяло правительству выступать в роли рефери на свободном рынке. Во Франции политическим суверенитетом наделялось централизованное государство (central state) как единственная сила, спо- 
собная поддерживать порядок и обеспечивать единство нации. Следуя той же логике, промышленная политика Франции давала государству возможность хозяйственной независимости: считалось, что только управление из центра может создать хозяйственный порядок и обеспечить достижение экономических целей нации. В Великобритании политический суверенитет получал каждый представитель высшего класса, которому гарантировалась юридическая защита от других представителей его класса, от королевской власти и от государственной бюрократии. Промышленная политика обеспечила независимость отдельным фирмам - вначале через либеральную политику laissez faire, а впоследствии активно защищая фирмы от вмешательства как рыночных, так и политических сил.

Наличие параллелизма между политической и промышленной культурами принимается большинством исследователей как некая данность, однако я считаю, что именно в этих параллелях содержится ключ к разгадке причин межстрановых различий в политике. Мой тезис состоит в следующем: расхождения в концепциях экономической эффективности проистекают из различий в традициях политической жизни. Иначе говоря, в процессе создания современной промышленной политики существующие принципы социального и политического порядка переносились в сферу хозяйства.

Ещё одно эмпирическое наблюдение заключается в том, что существующие национальные промышленные стратегии воспроизводятся при столкновении с новыми задачами. Когда появляется проблема, прежде перед нацией не стоявшая и требующая политического выбора, новые институты создаются по образцу тех, что уже использовались ранее. Например, если в прошлом в данной стране для повышения эффективности производства поощряли ценовую конкуренцию, то в будущем ту же стратегию повышения эффективности будут применять и в новых отраслях. Я покажу, что стратегии промышленной политики воспроизводятся не только благодаря тому, что повторять уже существующее проще в организационном плане, а потому, что именно государственные институты воплощают те представления о причинно-следственных связях, на основе которых политики принимаются за решение новых проблем. Обратившись к примеру воспроизводства и эволюции политики в железнодорожной отрасли в первые 75 лет её существования, я также покажу роль таких представлений о причинных связях в сохранении и изменении стратегий промышленной политики.

Прежде чем перейти к теоретической части, кратко опишу стратегии государственной промышленной политики конца XIX века. Что представляли собой различные стратегии, и как они развивались в дальнейшем? Промышленная политика США на пороге XX столетия, ориентированная на защиту экономических свобод, стремилась предотвратить любые ограничения свободы торговли и насаждала ценовую конкуренцию. Федеральная антимонопольная политика была нацелена на борьбу с попытками ценовых сговоров и на предотвращение объединений, ведущих к монополизации отрасли. Цель отраслевых регулирующих агентств состояла в том, чтобы не допускать образование картелей и поддерживать ценовую конкуренцию. В основе этой стратегии лежало представление о том, что залогом роста является естественный отбор фирм на нерегулируемых рынках. В XX веке антимонопольное законодательство расширялось и ужесточалось; теперь оно применяется для регулирования самых разных отраслей - от нефтяной промышленности до телекоммуникаций и компьютеров. Регулирующие агентства контролируют установление цен и уровень конкуренции в таких отраслях, как производство электроэнергии, добыча природного газа, радио, телевещание и авиаперевозки. Стратегии промышленной политики в США поддерживают рынок и тем самым укрепляют уверенность чиновников в том, что неограниченная конкуренция способна обеспечить процветание практически любой отрасли.

Во Франции всё было по-другому. Система управления промышленностью, сложившаяся к концу XIX века, опиралась на политику государственной координации, впоследствии ставшую известной как государственный дирижизм (public concertation) в хозяйственной жизни. Цель промышленной политики состояла в управлении развитием ключевых производственных и инфраструктурных секторов, поскольку считалось, что только государство в силах защитить прогресс от действий предпринимате- 
лей, эгоистично преследующих собственные интересы, и иррациональных рыночных сил. В начале XX века французские технократы пытались создавать смешанные государственно-частные компании и проводить национализацию предприятий. С появлением в 1950-х гг. промышленного планирования технократы получили контроль над всеми секторами экономики. Манипулируя целевыми показателями пятилетних планов, государство теперь могло управлять промышленностью, создавая новые и отказываясь от устаревающих отраслей. В основе французской политики лежало представление о том, что класс экспертов-технократов справится с управлением хозяйством лучше, чем кучка эгоистичных капиталистов или «невидимая и неразумная рука» рынка.

Если в конце XIX века политика США передавала власть над хозяйственной жизнью рынкам, а политика Франции - технократам, то политика Великобритании наделяла властью предпринимательские фирмы. Под лозунгом невмешательства в хозяйственную жизнь Великобритания поощряла создание картелей и защищала мелкие фирмы, препятствуя враждебным поглощениям. Мысль о том, что предпринимательский дух мелкой фирмы является основным источником экономического роста, продолжала задавать контуры политики и в XX веке. Чтобы уберечь небольшие предприятия от банкротств во время кризисов 1920-1930-х гг, британское правительство поощряло создание картелей. Когда после Второй мировой войны правительство лейбористов по идеологическим соображениям национализировало часть промышленных предприятий, их руководство сохранило за собой право на самостоятельные решения, не зависящие от колебаний политического курса. Более поздняя попытка Великобритании повторить французский опыт промышленного планирования провалилась, поскольку под предлогом развития перспективных отраслей государство занималось спасением убыточных предприятий. В 1980-х гг. правительство Маргарет Тэтчер вернулось к политике, открыто наделяющей хозяйственной властью фирму. Таким образом, в XX веке промышленная политика защищала частную инициативу от вмешательства рынка и государства и содействовала ориентированному на прибыль предпринимательству, которое считалось залогом экономического роста.

Как США, Франция и Великобритания пришли к упомянутым стратегиям? Большинство политологических, экономических и институциональных подходов не могут ответить на этот вопрос, потому что принимают как данность все те аксиомы современного мировоззрения, которые им следовало бы сделать объектом исследования, выявив их социально сконструированный характер. Не подвергается проблематизации распространённое мнение о том, что действия совершаются ради максимизации экономической полезности и политической борьбы за коллективные материальные интересы. Экономическая рациональность принимается как нечто самоочевидное, и институты рассматриваются как нечто существующее независимо от поддерживающих их социальных практик. По сути, эти подходы позволяют лишь перевести на теоретический язык обыденные представления, характерные для современной картины мира, а затем использовать теории как инструмент изучения той же современности. В результате политологи, экономисты и институционалисты остаются в пределах современного мировоззрения и не интересуются механизмами возникновения и развития новых социальных институтов и соответствующих им концепций реальности, а ведь именно интерес к проблемам такого уровня обусловил развитие социальных наук в XIX веке. Политологи выясняют, почему та или иная группа интересов побеждает в конкретном политическом споре, вместо того чтобы задаться вопросом о том, как вообще получилось, что в современном мире именно корпоративные группы (нации, классы, расы или группы интересов) стали теми осями, по которым строятся идентичность и действие (исключение представляют следующие работы: [Lipset, Rokkan 1967; Anderson 1983; Thomas, Meyer 1984; Ruggie 1993]). Экономисты пытаются разгадать универсальные принципы экономической эффективности, вместо того чтобы выяснять, отчего именно идея прогресса стала основой развития современного общества, и каким образом возникает та или иная концепция прогресса и эффективности (ответы на этот вопрос можно найти в ряде работ экономсоциологов, см.: [Granovetter 1985; DiMaggio, Powell 1991; Zelizer 1993]). Институционалисты стремятся выяснить, какая из институционализированных практик больше подходит для проведения той или иной политики, вместо того что- 
бы попытаться понять, как эти практики становятся институтами, т. е. наделяются коллективным смыслом и благодаря этому продолжают существовать (исключениями являются следующие работы: [Berger, Luckmann 1966; Meyer, Boli, Thomas 1987; Jepperson 1991; Scott 1992]). Далее я буду называть эти три подхода реалистическими, чтобы отличать их от социально-конструктивистских подходов к тем же сюжетам. Полагаю, что экономические, политологические и институционалистские версии реалистического подхода затемняют природу современной рациональности, так как принимают слишком многое в социальном мире за чистую монету, вместо того чтобы спросить, каким образом мир стал таким, каков он есть.

\section{Политический реализм}

Идея демократического правления предполагает, что политический выбор отражает соотношение власти между различными общественными интересами. Эта идея является ключевой для политологических концепций, объясняющих политические решения через оценку влияния соперничающих групп. Многие представители плюралистического подхода и неомарксисты изображают процесс принятия решений как конфликт между конкурирующими группами интересов; принципиальная разница между либералами и радикалистски настроенными авторами сводится к тому, признают ли они справедливость правил политического соревнования. Концепция борьбы интересов в плюралистическом подходе восходит к «Хозяйству и обществу» М. Вебера, который изучал возникновение разнообразных политических группировок. Истоки реализма неомарксистов кроются в работе К. Маркса «18 брюмера Луи Бонапарта», где описывается борьба группировок в высшем классе за контроль над государством в период правления короля Луи-Филиппа. В основе этих теорий лежит обыденное по своей сути представление о том, что политические решения отражают относительную власть конкурирующих групп. Данная идея настолько укоренилась в политической науке, что её принимают как данность даже признанные новаторы, чьи работы совершили переворот в этом направлении исследований. Теория рационального выбора дополнительно предполагает, что интересы могут быть объективно оценены с помощью математического моделирования; подходы, изучающие коалиции, утверждают, что, поскольку группы интересов меняются со временем, в разное время складываются разные фракции.

Такой подход позволяет понять, чем определяется выбор одной из имеющихся в отдельном государстве политических альтернатив, но не работает в сравнительных исследованиях. Во-первых, он не объясняет происхождение существующи политических альтернатив (исключением являются следующие работы: [Bachrach, Baratz 1963; Lukes 1974]). В разных странах наборы политических альтернатив почти всегда различаются, а в большинстве случаев и взаимно исключают друг друга, поэтому решающее значение приобретает ответ на вопрос о том, как сложился тот или иной набор вариантов. Возьмём как пример планирование размещения железнодорожных линий. В Великобритании даже не обсуждали возможность государственного планирования, а во Франции не помышляли о частном планировании. Выяснив, по каким причинам тот или иной вариант не рассматривался в политических дискуссиях, мы поняли бы, почему в Великобритании планированием занимались частные фирмы, а во Франции государство, однако теория групп интересов обычно оставляет без внимания вопрос происхождения альтернатив, которые рассматриваются на этапе выбора политики. Во-вторых, теория групп интересов не может объяснить, вследствие чего в одной стране слабая группа добивается более выгодной для себя политики, чем более сильная группа в другой стране. Теория групп интересов бездоказательно допускает, что сильнейшая группа всегда выигрывает; поэтому, когда в политической борьбе побеждает более слабая группа, сторонники этой теории предаются пространным рассуждениям о том, что данная группа либо не была слабой, либо не победила. По сути, сила группы определяется исходя из её способности побеждать. В-третьих (и, возможно, это самое важное обстоятельство), концепция политического реализма не проливает свет на то, в силу чего группы со сходными интересами в разных странах имеют разные представления о выгодной им политике. Представители железных дорог, даже находясь в сходном положении, в каждой из рассматриваемых трёх стран боролись за свой вариант 
промышленной политики. Полагаю, что теории политического реализма не способны объяснить межстрановые различия в политике потому, что не ставят перед собой вопрос о том, откуда берутся группы интересов, как возникают политические проблемы, требующие решения, и каким образом складывается набор альтернативных политических мер.

\section{Экономический реализм}

Согласно идее экономического детерминизма и в повседневном дискурсе, и в академических теориях социальные системы подчиняются экономическим законам, которые задают структуру институтов. Политические институты следуют экономическим законам на макроуровне, где в процессе отбора воспроизводится адаптивная политика, и на микроуровне, где из совокупности индивидуальных действий по максимизации полезности возникают институты, построенные на началах коллективной рациональности. На обоих уровнях экзогенные и универсальные экономические законы управляют миром и производят социальные практики. Современная экономическая теория представляет собой научное предприятие по поиску и детальному изучению этих законов. Её основной постулат: экономическая реальность единообразна, и везде действуют одни и те же внешние законы. Как следствие, институциональная среда не рассматривается в качестве фактора, влияющего на хозяйственную жизнь и законы, что утверждают экономсоциологи [White 1988; Zelizer 1988]. Напротив, среда рассматривается как набор переменных, воздействие каждой из которых предусмотрено в общей теории экономического мира. Разобравшись в общей теории, мы получаем полное понимание хозяйственного поведения и институтов.

В макроэкономических подходах предполагается, что экономические институты, включая политику регулирования, развиваются в направлении всё более эффективных решений и наилучшим образом приспосабливаются к новым факторам среды. Согласно одним подходам отбор более эффективных политических инструментов осуществляют политики и заинтересованные стороны, согласно другим политический выбор зависит от функциональных возможностей. В недавней литературе по вопросам развития вновь набирает популярность идея о логике индустриализации, предполагающая, что каждой стадии экономического развития соответствует особая совокупность политик и сопутствующих им хозяйственных институтов. Из концепции Александра Гершенкрона о догоняющей модернизации [Gerschenkron 1962] следует, что в ответ на отставание от соседей государство принимает активные меры по стимулированию экономического роста. Сторонники неоклассической теории принимают как данность, что раз в США наблюдается экономический рост, то проводимая там политика свободного рынка соответствует универсальным законам экономики, и нередко предсказывают конвергенцию политики других стран с моделью, используемой в США. Версия политической экономии современного капитализма, предложенная А. Шонфилдом [Shonfield 1965], выдвигает в качестве идеальной институциональной модели французскую систему промышленного планирования, которая должна вскоре превзойти и вытеснить политику невмешательства в экономику. Эти макроподходы основываются на том, что самыми эффективными политическими институтами являются те, которые были отобраны либо рационально действующими агентами государства, либо «невидимой рукой» международного рынка.

Новая институциональная экономическая теория и теория рационального выбора начинают объяснение социальных институтов с микроуровня. Институционализм в экономической теории связывает глобальные экономические институты, такие как промышленная политика, с деятельностью движимых личными интересами акторов, максимизирующих полезность. Как полагает Д. Норт, эффективная политика возникает благодаря тому, что политические деятели, стремящиеся максимально увеличить доходы государства, создают институты, максимизирующие доходы индивидов [North 1981]. С точки зрения теории игр и теории трансакционных издержек институты макроуровня - это видимые проявления микроэкономической деятельности, поэтому внимание следует сосредоточить на изучении микроуровня. Теория рационального выбора предполагает, что совокупность политических решений 
индивидов, преследующих собственные интересы, образует эффективные политические институты, способные обеспечить утилитарный компромисс и тем самым максимизировать коллективное благо.

С течением времени всё меньше находится эмпирических подтверждений тезису о том, что универсальные экономические законы задают структуру социальных институтов. Когда США повторили успех Великобритании, став мировым лидером по темпам экономического роста, причину этого ещё имело смысл видеть в том, что экономическая политика двух стран (внешне выглядящая как невмешательство государства в экономику) следует универсальным законам экономики. Однако этот тезис теряет доказательную силу в период, когда высокие темпы роста показывают страны с совершенно иными моделями развития, такие как Швеция, Франция и Япония. Если существенно отличающиеся друг от друга хозяйственные системы обеспечивают сопоставимые темпы роста, то это значит, что универсальные экономические законы должны предполагать не один, а много путей развития; должны допускать множество вариантов, а не исключать все, кроме единственно верного. И если рост может обеспечить также политика, стимулирующая образование картелей, или политика избирательной государственной поддержки отдельных отраслей промышленности, то прежнее понимание законов экономики оказывается во многом некорректным. В современных обществах очень много внимания уделяется исследованию абстрактных экономических законов, побуждающих людей действовать определённым образом; причём существование таких законов не подвергается сомнению. Однако в действительности хозяйственная логика и образцы деятельности значительно различаются в зависимости от контекста. На это обратили внимание ещё теоретики ранней институциональной экономики. Так, Т. Веблен считал, что экономическая теория должна изучать эволюцию хозяйственного поведения, поскольку способы хозяйственной деятельности изменяются в зависимости от исторических условий, а не направляются некими внешними силами [Veblen 1904]. Но если экономические законы обусловлены контекстом, а не универсальны, и разные совокупности этих законов выполняют роль функционально действенных альтернатив, то возникает вопрос: каковы же причины различий хозяйственных систем?

\section{Институциональный реализм}

Новый институциональный (стейтистский) подход в политической науке возник в ответ на неспособность политологической и экономической парадигм объяснить причину исторической устойчивости национальных стратегий промышленной политики, поэтому был предложен такой ответ: стратегии политики воспроизводятся вследствие инерционности государственных структур управления. В этой версии реалистического подхода социальный институт (то есть обычай) получает тот же онтологический статус, что и, к примеру, здание небоскрёба. Предполагается, что социальные структуры существуют независимо от людей, действующих в их рамках. Без внимания остаётся важнейший вопрос: как миллионы людей достигают общего понимания реальности, достаточного для того, чтобы мотивировать их заниматься всем тем, что они делают каждый день (встают утром, скрепляют бумаги, откручивают винты, изготовляют гамбургеры, ходят на почту) и благодаря чему продолжают существовать социальные институты. (Cp.: [Sewell 1992].) Институты современного государства во всей их полноте воспроизводятся в деятельности множества людей, чьи общие когнитивные схемы наделяют смыслом как коллективный проект современности, так и повседневную деятельность. Вместо того чтобы объяснить происхождение общих концепций реальности, лежащих в основе обычаев, эта теория овеществляет обычай, используя термины типа «институциональное равновесие», «ветвление», «зависимость от пройденного пути», «политическое обучение», «инерция», и в результате нередко скатываются в тавтологию, утверждая, что институциональные практики воспроизводятся потому, что они инерционны, то есть продолжают воспроизводиться. Направление в институциональном подходе, сторонники которого всё же обращаются к вопросу о причинах устойчивости институтов, представляется более плодотворным (см., например: [Meyer, Boli, Thomas 1987; DiMaggio, Powell 1991; Jepperson 1991]). 
В данном подходе центральное место отводится организационным ресурсам государства. Существующие ресурсы облегчают принятие тех стратегий политики, которые изоморфны уже имеющимся мерам и не позволяют реализовать принципиально новую политику. Например, ограниченность организационных ресурсов федеральной администрации США в XIX веке обусловила распространение таких стратегий управления, которые не требовали значительного вмешательства государства во многие институциональные сферы [Skowronek 1982]. Аргументация институционалистов не сводится к тому, что одни страны располагают большими организационными ресурсами, чем другие. Они утверждают, что способность государства проводить ту или иную политику ограничена возможностями управления, и причиной провала определённых мер становится недостаток у государства организационных ресурсов для их реализации [Skocpol, Finegold 1982]. Исторические исследования государственной политики подтверждают, что правительства склонны решать новые проблемы с помощью привычных стратегий [Krasner 1978; Zysman 1983; Ikenberry 1988], и сторонники институционального подхода считают это обстоятельство доказательством онтологической объективности институтов.

Институциональный (стейтистский) реализм объясняет преемственность политики организационными характеристиками данного государства. Но это толкование не учитывает, что за последние 150 лет национальные государства настолько выросли, что уже не похожи на себя прежних [Tilly 1975]. Американское государство образца середины XIX века, содержавшее весьма немногочисленный штат служащих (не считая военных и работников почтовой связи), вскоре превратилось в организациюлевиафана, дающую работу миллионам людей. Однако национальные стратегии промышленной политики оставались при этом поразительно неизменными на протяжении всего периода возникновения и бурного роста современных государств. Далее я покажу, что причина воспроизводства политики заключается не в организационных ресурсах государства, а в особенностях социально сконструированной логики хозяйственной деятельности. В действительности, государства часто создают новые инструменты политики, требующие организационных ресурсов, которыми они не располагают, тем не менее эти политики строятся по тому же принципу, что и уже существующие.

\section{Культура и смысл в современных государствах}

Существующие подходы к публичной политике в силу того, что они разрабатывались для объяснения выбора внутренней политики, редко позволяют объяснить значительные различия между национальными стилями этой политики. Иными словами, большинство теоретиков обычно начинают с вопроса: «Почему США в 1953 г. приняли одну поправку к антимонопольному закону, а в 1962 г. — совсем другую?». И предлагаемые ответы на этот вопрос едва ли помогают понять, почему, например, США во всех случаях прибегают к антимонопольному законодательству для управления промышленностью, а Франция всегда опирается на активное государственное регулирование. Проблема заключается не в том, что национальные политические стратегии трудно предсказать, но в том, что существующие теории не позволяют выявить условия, необходимые для формулирования такого рода предсказаний: «Какой тип политики выберут США для управления новой отраслью? - Делайте ставку на политику, усиливающую ценовую конкуренцию»; «Какова вероятность того, что США назовут какую-либо отрасль национальным чемпионом (как это порой делает Франция) и используют государственные средства для того, чтобы превратить её в монополию? - Можете биться об заклад, что этого не случится».

Для такого рода общих предсказаний вовсе не обязательно разбираться в деятельности групп интересов, микроэкономических моделях и организационных ресурсах данного государства. Необходимо лишь понять логику, лежащую в основе проводимой политики, и это позволит предсказать будущую политику, ибо политика разных стран подчиняется совершенно разной логике и может опираться на закономерности естественного отбора (natural selection), как в США, государственного дирижизма, как во Франции, или какие-либо другие. Эта логика вполне осязаема и устойчива. Понимая её, мы тут 
же распознаём типично французскую манеру планирования железнодорожной политики или типично британское нежелание государства экспроприировать частные земли в пользу железных дорог.

Исследователи национальной политики государства не выдвигали теорий по поводу её логики, поскольку идея о том, что национальные хозяйства следуют разным культурным моделям, не стыкуется с существующим ныне мировоззрением, согласно которому экономические явления (подобно физическим) подчиняются единому набору законов в рамках одной общей теории. Промышленная политика и прочие макроэкономические институты подпадают под эту теорию. Представители социальных наук в значительной степени разделяют точку зрения, что социальная реальность едина, и пытаются выявлять универсальные социальные аксиомы. Исключение составляют этнографы, которые ориентированы на обнаружение принципиально иных, не вписывающихся в универсальные экономические законы принципов поведения в досовременных обществах, и ожидают столкнуться с практиками и смыслами, локальными по своему происхождению. Приступая к анализу социальных систем, они обладают преимуществом, которого лишены исследователи современности, ибо знают наверняка, что смыслы, представленные в досовременных институтах, суть продукт локального воображения (local fictions). Напротив, когда те, кто живёт в современную эпоху, принимаются анализировать свой мир, они исходят из того, что социальные институты отражают внешние экономические законы, и в результате не считают, например, неоклассическую экономическую теорию - этот культурный артефакт - институционализированной смысловой системой (institutionalized meaning system), формирующей политические решения и индивидуальное поведение. Наоборот, они полагают неоклассическую теорию истиной в противовес этнографам, не считающим истинными теории аборигенов о связи между благоволением духов и урожаем. В последние годы успехи хозяйств, построенных не на неоклассических экономических принципах [Hamilton, Biggart 1988], легко могли бы показать экономистам, что экономическая теория тоже является системой верований: ведь эти успехи побуждают отказаться от мысли об универсальности экономических принципов. Вместо этого экономисты-неоклассики защищают свои теории, утверждая, что хозяйства, организованные не на основе рыночных принципов, подвергались противоестественным политическим манипуляциям, которые всё равно дадут о себе знать в долгосрочной перспективе. Словом, с тех пор как социальные науки принялись изучать современность, они начинают с выявления социальных законов, единых для всего земного шара.

\section{Институционализированные смысловые системы}

Я утверждаю, что, следуя примеру этнографов и рассматривая институционализированные смыслы современного общества как продукт локальных социальных процессов, мы сумеем лучше ориентироваться в вопросах публичной политики. Для этого надо перейти от постановки вопроса в духе реализма («Каким универсальным рациональным законам подчиняется социальная реальность?») к конструктивизму («Каким образом конкретные рационализированные социальные институты складываются в конкретном социальном контексте?»). Я также полагаю, что различия между рационализированными смысловыми системами (rationalized meaning systems) объясняют значительные различия в политике разных стран и что рациональность в основе своей обусловлена культурой.

Существует несколько крупных типов институционализированных смысловых систем. Социальные науки возникли как результат попыток осмысления перехода от досовременных религиозных смысловых систем к современным секуляризованным рациональным смысловым системам. Все религиозные смысловые системы ориентируют институты на служение высшим силам, обещая воздаяние в загробной жизни. Однако эти системы представляют высшие силы и религиозную этику отлично друг от друга, так что социальные практики, настроенные на спасение души, принимают заметно различающиеся формы. Аналогично все рациональные смысловые системы ориентируют институты на науку и эффективность, обещая накопление благ посредством покорения природы. При этом такие системы представляют природу рациональности и инструменты накопления неодинаково, так что социальные прак- 
тики, ведущие к прогрессу, тоже принимают заметно различающиеся формы. В результате, несмотря на то что мы ожидаем найти весьма несходные решения коллективных проблем в рамках радикально различающихся культурных систем (например, в мусульманском фундаментализме, британской секуляризованной рациональности или бразильском шаманизме), мы также обнаруживаем весьма непохожие решения и в рамках рационализированных культурных систем, которые кажутся нам схожими.

\section{Практики и смысл}

В религиозных, рационализированных, мистических и тотемных обществах действия закрепляются в обычаях тогда, когда наполняются смыслом. Иными словами, действия становятся привычными только тогда, когда у акторов формируется коллективное понимание их целей. Поскольку осуществление всех социальных практик требует их понимания на интерсубъективном уровне, все практики несут в себе тот или иной смысл. Зачастую он заключается в обыденной, принимаемой как само собой разумеющееся, связи между целями и средствами по принципу «так устроена жизнь». В результате акторы часто не замечают смысла как такового, воспринимая коллективные целесообразные связи целей и средств как непосредственное отражение реальности. А. Хиршман вслед за К. Поланьи называет этот смысловой уровень скрытым измерением (tacit dimension), то есть «предположениями и мнениями, которые разделяет группа, и настолько очевидными, что они никогда не выражаются полностью или систематически» [Hirschman 1977: 69]. В современных обществах мы, как правило, отрицаем культурную составляющую явно инструментальных связей.

Будучи интегрированными, цельными смысловыми системами, все культуры претендуют на точное отображение реальности и отрицают существование альтернативы. Может быть только один Бог (или один пантеон богов), только одна общая теория физики, только один набор экономических законов. Неудачные попытки обществоведов показать смысловую нагрузку рационализированных институтов являются результатом этой особенности смысловых систем. Проблема коренится в неспособности к самонаблюдению. Изнутри весьма непросто видеть любые культурные рамки как таковые. Западные миссионеры легко замечали чужие смысловые системы, рассматривая их как очевидные суеверия, и продолжали верить, что их собственная религиозная система воплощает суть реальности. Аналогично исследователи современности без труда замечают, что чужие социальные институты обусловлены верованиями, социальными по своему происхождению («Опять эти ненормальные французские социальные инженеры...»), однако продолжают верить, что их собственные, инструментально рациональные социальные институты суть воплощение «подлинной» сущности реальности.

Чтобы объяснить очевидные различия между современными социальными системами, аналитики отделили инструментально рациональные институты от сферы культуры и приписали все несходства последней. Таким образом, термин «культура» предназначают для институтов, которые в современном мире считаются скорее символическими, нежели инструментальными: искусство, религия, мода и образование [Eisenstadt, Abitol, Chazan 1987]. Инструментальные социальные институты (такие, как правительство, рынки, фирмы и наука) в социальных науках обычно воспринимаются как не связанные с культурой (acultural). Это разъединение для социальных наук формализовал Толкотт Парсонс. На уровне индивида поведение также разделяется на культурное и инструментальное, и действия, за которыми не очевиден эгоистичный расчёт, принято объяснять культурой и нормами [Elster 1989]. Эта общая тенденция вывела инструментально рациональные институты за рамки культурного анализа и тем самым выхолостила исследования культуры. Каким образом антимонопольная политика символизирует рациональный мир? Такой вопрос просто невозможен, какие бы цели он ни преследовал. Следовательно, основной парадокс современности заключается в широком разнообразии культурных форм, которые можно встретить в инструментальных институтах разных наций, хотя все эти институты, как предполагается, ориентированы на единый набор экономических законов. Пытаясь разрешить эту дилемму, вместо того чтобы признать все институты и типы поведения обусловленными культурой 
и тем самым подвергнуть рациональность проблематизации, социальная наука выделила несколько культурных институтов, обусловливающих различия в национальных моделях институтов и поведения. И всё же инструментальные институты, отражая принятые в этом мире цели и средства, тем самым неизбежно оказываются обусловленными культурой.

Передо мной вовсе не стоит цель опровергнуть современные взгляды на мир или предложить метод социальных наук, настолько радикально рефлексивный, что он отрицает способность современности исследовать самое себя. Просто я предполагаю, что для постижения различий между инструментально рациональными культурными системами необходимо увидеть их как социальный феномен. В той мере, в какой современные институты выражают попытки представить мир в рациональных научных терминах, институты будут различаться в силу того, что общества опираются на разные репрезентации такого рода.

Вообще-то социальные конструктивисты уже высказывали подобные мысли в отношении некоторых других рационализированных сфер [Berger, Luckmann 1966]. Исследователи национального государства утверждают, что тот или иной конкретный исторический социальный конструкт есть неотъемлемая часть развития рациональности, однако социальная форма современного государства ни в коем случае не являлась исторически неизбежной [Anderson 1983; Thomas, Meyer 1984; Sewell 1985; Ashcraft 1986; Krasner 1993]. Институциональные экономисты [Veblen 1904; Commons 1934] и экономсоциологи [Granovetter 1985; White 1988; Zelizer 1988] утверждают, что модели рационального экономического поведения возникают в силу идентифицируемых исторических причин, а затем социально конструируются в качестве эффективных моделей. Новый институционализм в теории организаций рассматривает рациональную организационную политику как социальный конструкт во многом подобно моему анализу политики государства [Meyer, Rowan 1977; Zucker 1977; DiMaggio, Powell 1983; Scott 1987]. А конструктивистски ориентированные социологи науки [Bloor 1976; Wuthnow 1987; Latour 1992] рассматривают рационализированные научные принципы как обусловленные историей социальные конструкты. У моего подхода много общего с макроконструктивистскими подходами к рационализированным институтам: в обоих случаях интерпретация субъективного смысла является ключевым элементом для понимания рациональности.

\section{Verstehen}

Большинство аналитиков полагают, что интерпретация не имеет никакого значения для анализа инструментальных институтов, поскольку их цели и средства и так очевидны. Предположение о том, что инструментальные практики что-то символизируют, кажется нелепым, поскольку их задача состоит лишь в том, чтобы выполнить свою миссию, и всё. Однако, как писал Вебер, сама суть социологии заключается в «интерпретативном понимании социального действия», а действие существует лишь тогда, «когда действующий индивид придаёт своему поведению субъективный смысл». У всякого действия есть субъективный смысл, и нет такого типа действия, которое соответствует объективной реальности, не порождая при этом аналитических проблем: «Вообще не идёт речь о каком-либо объективно “правильном” или метафизически постигнутом “истинном” смысле» [Weber 1978: 4]2. Иными словами, никакой отдельно взятый тип действия нельзя постичь сам по себе. Действия открываются пониманию обществоведа, только когда удаётся уловить их субъективную цель, а также причинно-следственные отношения, которые, в понимании актора, связывают действие с целью. Этот процесс интерпретации Вебер обозначает термином «понимание» (verstehen). Я же стремлюсь понять, каким образом различные рационализированные социальные системы выстроили совершенно непохожие связи между социальными процессами и экономическим ростом.

2 Цит. по: Вебер М. 1990. Основные социологические понятия. В сб.: Вебер М. Избранные произведения. Пер. с нем. Ю. Н. Давыдова. М.: Прогресс; 603. 
Вебер ещё более усложнил наше понимание природы инструментальной рациональности, анализируя рациональные практики относительно их идеального типа, что предполагает их организованность вокруг некоего универсального набора причинно-следственных связей. Веберовский анализ рациональности резко противоречит его исследованиям религиозных социальных систем, в которых религии представлены во всей их сложности и неоднородности. В сущности, большинство аналитиков раннего периода социологии, как и Вебер, рассматривали современность как единую реальность.

\section{Рационализированные смысловые системы}

С этих культурологических позиций рациональность и наука являются духом (Geist), наполняющим и мотивирующим социальное действие в современную эпоху. Рациональный мир подчиняется не всеобъемлющим духовным или мистическим силам, а определённому набору универсальных, подвергнутых «разволшебствованию» (disenchanted) физических и социальных законов. Задача современных социальных систем - раскрыть эти законы и с их помощью овладеть миром. Успешность данного предприятия (которое, если верить экономистам, подчинено врождённому желанию накопления богатства) расценивается как прогресс и измеряется совокупным накоплением благ (aggregate accumulation of goods). По мере того как культурным средоточием коллективного действия становились ориентированные на прогресс рациональность и наука, на смену Церкви и монархии приходили бюрократия и рынок. Подобно религиозным, рационализированные смысловые системы объясняли происхождение социального порядка внешними общими социальными законами. Там, где религиозные социальные системы ссылаются на высшее преобразующее сознание как инкарнацию преобразующей способности индивидуального сознания, рациональные системы отсылают к высшим физическим и социальным законам, которые предсказуемым образом правят миром.

Следовательно, культурные системы современных обществ нацелены на поиск неизменных физических и социальных законов, позволяющих человечеству изменять мир во имя прогресса. Социальные науки - неотъемлемая часть этого процесса, поскольку они стремятся понять функции сложных социальных обычаев и обнаружить цель даже тех институтов, у которых нет явной ориентации на накопление. Например, с точки зрения теории рационального выбора подходы к изучению социальных норм стремятся показать, что, несмотря на возможное отсутствие очевидной цели на уровне индивида, эти нормы служат некоей высшей рациональности (high-order rationality) [Elster 1989]. Теория функционализма Парсонса была нацелена на то, чтобы показать: существующие символические (и очевидно бесполезные) институты современного общества на самом деле могут выполнять жизненно важные функции осуществления социальной интеграции и поддержания социального порядка [Parsons 1951; 1971]. Таким образом, любая черта социальной жизни рассматривается современным мышлением как часть единого проекта по развитию накопительной миссии человечества. Современное мировоззрение и социальные науки признают, что у прогресса есть и нематериальные измерения, в том числе затрагивающие проблемы справедливости и демократии, однако зачастую они относят и эти измерения к функции накопления, утверждая, например, что экономические свободы - залог экономического роста [Bowles, Gintis 1986].

Словом, современность существенно отличается от предшествующих эпох, однако это не имеет принципиального значения, поскольку социальные и экономические законы, которые, как мы считаем, «открываются» нам на основании опыта, на самом деле являются продуктами социальной жизни. Подобно тому как в религиозных социальных системах божества наделяются характеристиками социальных систем, которыми они управляют, рационализированные законы социальной реальности перенимают характеристики подчинённых им социальных систем. 


\section{Эпистемология рационализированных систем}

В своём стремлении к прогрессу рационализированные общества используют научную эпистемологию, чтобы выявить единые законы физического и социального мира. Во всех рационализированных сферах — в науке, управлении, хозяйстве и публичной политике - знание подчинено этой эпистемологии. Оно представляет собой обобщённые суждения о мире, основанные на эмпирических данных и организованные в виде причинно-следственных связей. Эти обобщения должны быть демистифицированы, прозрачны и логически соотносимы с уже существующим знанием. А эмпирические подтверждения должны следовать установленным процедурам.

В отличие от религиозных смысловых систем, претендующих на точное содержательное знание о реальности, рациональные смысловые системы находятся в поиске метода, который поможет понять реальность, поэтому их субстантивные законы постоянно корректируются и изменяются. В результате фальсификация существующих причинно-следственных связей посредством новых свидетельств не представляет никакой угрозы для рационализированных смысловых систем. Напротив, опровержения, скорее, доказывают применимость метода, и эпистемологические правила выстроены так, чтобы стимулировать фальсификации. Рациональность представляет построение знания как кумулятивный и итеративный процесс, и даже когда смена парадигмы сметает всё устоявшееся в той или иной сфере знание, на эту только что отжившую парадигму смотрят с ностальгическим умилением, воспринимая её как необходимый шаг на общем пути к просвещению. Например, мы признаём, что только ортодоксальная макроэкономическая теория могла породить неортодоксальное кейнсианство; а человечество вынуждено было верить в то, что земля плоская, чтобы впоследствии доказать, что это не так. Добавим, что религиозные системы не выдерживают разоблачений с такой лёгкостью.

Эпистемологические принципы схожи во всех рационализированных сферах, правила же получения подтверждений, к которым они прибегают, различны. Естественные науки отличаются высокой степенью формализации и используют чёткие, кодифицированные, эмпирически проверяемые правила. Экономическая теория тоже весьма формальна, но она, как и математика, при доказательстве теорий допускает использование одной только логики, и правила отдают приоритет логике перед эмпирическими данными. Экономическая теория постоянно подвергается проверкам со стороны реального мира, так что господствующие теории могут быть опровергнуты таким опытом, как депрессии [Hall 1989]. Все виды теорий могут разрабатываться и распространяться как практиками, так и профессиональными теоретиками, однако зачастую (особенно это касается теорий менеджмента) они подтверждаются одним-единственным «убедительным» примером (кейсом). Поскольку считается, что теории менеджмента доступны для понимания любому человеку, выхваченные из их контекста причинноследственные связи нередко «вдруг открываются» практикам и распространяются через публикации харизматических лидеров или популярную прессу. В естественных же науках доморощенные теории, как правило, продвигаются не дальше бульварных газет. Отчасти потому, что в этом случае приняты более точные правила доказательств, и отчасти потому, что природа не считается столь гибкой, чтобы её можно было объяснять различными, не связанными между собой теориями. Теория промышленной политики эпистемологически ближе к теории менеджмента, нежели к научной теории, поскольку её общие принципы представляются вполне доступными для понимания, и непрофессионал вполне способен понять, например, логику антитрастовой или прокартельной политики и предложить свои возможные варианты политики просто на основе здравого смысла.

Теория как рационализированный смысл во всех этих сферах феноменологична, предполагая интерсубъективные трактовки причины и следствия. Как правило, акторы улавливают смысл на основе опыта, будь то смысл силы тяготения (сфера науки), рыночной конкуренции (экономическая теория), иерархической цепочки (менеджмент) или антимонопольного судебного процесса (политика). Понимание того, что сила тяготения универсальна, неодушевлённа и не связана ни с какой мистикой, прихо- 
дит не из школьного курса физики, а из непосредственного опыта: для всех вокруг она обладает этими же характеристиками. Аналогично американцы узнают о том, что антимонопольная судебная практика укрепляет механизмы естественного отбора, ведущие к макроэкономической эффективности, не из школьного курса обществоведения, а в результате повседневного опыта: все вокруг воспринимают антимонопольную политику именно так. Значительная часть современных представлений возникла в результате подобного пассивного социального конструирования, в ходе которого законы природы, экономики и т. д. находят отражение в предписаниях к действию, а затем интернализируются в индивидуальных когнитивных структурах. Сказать, что эти законы суть социальные конструкты, значит просто утверждать, что они являются репрезентацией реальности, но не самой реальностью. Закон тяготения - в отличие от самой силы тяготения — представляет собой обусловленную культурой схему, репрезентирующую и объясняющую данное явление.

\section{Термины, используемые в социокультурном подходе к анализу политики}

Подход к анализу политики, сконцентрированный на культуре, которая воплощена в институционализированных причинно-следственных связях, требует применения особых терминов.

\section{Индустриальные культуры}

Индустриальные культуры (industrial cultures) — это институционализированные принципы промышленной организации и хозяйственного поведения, принятые в той или иной стране [Dyson 1983]. Принадлежа к сфере культуры, они состоят из практик смыслов, с ними связанных. Смысловую сторону культуры обозначают понятиями «троп», «фрейм», «идеология», «мировоззрение», «типология», «коллективное бессознательное», «габитус», «коллективные репрезентации», «набор инструментов» (toolkit) и «эпистема». Я считаю, что смыслы неотделимы от практик, по поводу которых они сконструированы, и поэтому использую словосочетание «индустриальная культура» для обозначения одновременно смысла и практики. В силу своей рационализированности индустриальные культуры обладают всеми характеристиками других рационализированных систем, пронизывают различные уровни действия, связывая их между собой. Они выстроены вокруг распознаваемых логик, отличающихся прагматичным здравым смыслом, зачастую сравниваются с природными феноменами (как, например, в предложенных М. Дуглас общих рассуждениях по поводу рационализированных институтов [Douglas 1986]), и если считается, что естественный отбор способствует рациональности, то делается умозаключение, что обычаи на уровне индивида, организации и публичной политики ориентированы на процессы отбора.

\section{Парадигмы промышленной политики}

Парадигмы промышленной политики (industrial policy paradigms) - это институциализированные принципы политического действия, усиливающие индустриальную культуру. Как отметил Питер Холл, парадигма политики подобна гештальту и структурирует то, как сами политики видят мир и свою роль в нём [Hall 1992]]. Парадигмы политики включают как практики (в форме стратегий), так и парные связи целей и средств (в форме принципов правительственных действий), укрепляют индустриальную культуру, создавая и поддерживая определённые модели поведения хозяйственных акторов и представляя эти модели как эффективные. Например, американская антимонопольная политика поощряет ценовую конкуренцию между фирмами и считает рыночную конкуренцию залогом макроэкономической эффективности. 


\section{Аргументация}

В эпоху модерна центральная задача политического порядка смещается от завоевания и подчинения территорий и населяющих их народов к исследованию и подчинению природы в целях обеспечения экономического роста. Политические структуры, чья функция изначально состояла в обеспечении военной мощи государства и поддержании социального порядка путём монополизации функции насилия [Hintze 1975], начинают трактоваться как инструменты экономической экспансии. Все национальные государства периода модерна, независимо от их политического устройства (республики, монархии или теологические государства), единодушно признавали ценность прогресса, определённого именно таким образом. Вскоре аргументация выживания или падения империй и правительств стала зависеть от темпов роста валового внутреннего продукта.

В процессе модернизации институты обеспечения политического порядка были пересмотрены в телеологическом ключе и представлены как способы обеспечения экономического роста и прогресса. Это происходило повсеместно, но с особой отчётливостью - в Великобритании, где Адам Смит преподнёс британские политические традиции как источник хозяйственного превосходства Великобритании. Вместе с тем, чем бы ни были те исторические закономерности и случайности, сочетание которых создало британскую политическую систему, они точно не были усилиями по максимизации валового национального продукта. Каждый раз, когда нации удавалось добиться успеха в хозяйственной деятельности, причину этого видели в особенностях политического устройства.

Современные промышленные стратегии наследуют характер политических институтов не только потому, что существующий государственный строй рассматривается как причина и основание для экономического роста, но и потому, что хозяйственные институты создаются на основе общих представлений о целях и средствах, заложенных в политической культуре. Политическая культура определяет характер новых промышленных и хозяйственных стратегий, в первую очередь за счёт того, что задаёт спектр хозяйственных и промышленных проблем, актуальных для данной нации, и ограничивает набор допустимых решений.

Во-первых, политическая культура задаёт восприятие проблемы, то есть определяет, какие события и практики нации будут считать проблемными. Цель любой политической культуры заключается в поддержании одних практик как конституирующих социальный порядок и в препятствовании другим как подрывающим социальные устои. Например, в США политические институты поддерживали местные сообщества, а в Великобритании - независимых индивидов; деструктивными в обеих странах считали концентрацию политической власти в руках централизованного государства. Когда стала складываться сфера промышленного производства, в США сочли, что неотъемлемой частью экономического порядка является независимость местного сообщества, а концентрация экономической власти в руках государства представляет угрозу этому порядку. В Великобритании конституирующим элементом экономического порядка полагали сохранение свободы индивидуальных экономических решений, а боролись против концентрации хозяйственной власти в руках частных предприятий. Во Франции концентрация государственной власти считалась единственным способом обеспечить политический порядок, а концентрация власти в сфере хозяйства рассматривалась как способ достичь экономического порядка, поэтому поощрялось создание крупных региональных железнодорожных монополий, действовавших под жёстким контролем государства.

Отправной точкой для принятия политического решения является то, как ставится коллективная проблема, требующая государственного вмешательства. Рассматриваемые страны совершенно по-разному определили, что является проблемой для развивающейся железнодорожной отрасли. В Великобритании таковой считали любую концентрацию промышленности, во Франции - неадекватную концентрацию и координацию. Направление, в котором предстояло развиваться промышленной политике, зависело 
от представления чиновников о том, что составляет угрозу хозяйственному порядку, которое, в свою очередь, было связано с осмыслением факторов, опасных для политической системы. От политической культуры зависела также оценка результатов проводимой политики и то, будет ли она продолжена или подвергнется пересмотру. Например, в США установление однородных цен рассматривалось как признак провала политики по защите конкуренции, тогда как в Великобритании это свидетельствовало об успехе политики по стабилизации отрасли. В США целью политики было устранение однородных цен, а в Великобритании на это предпочитали не обращать внимание.

Во-вторых, встроенные в политическую культуру представления о причинно-следственных связях задают допустимые решения, то есть определяют набор политических стратегий, позволяющих решать политическую проблему. Например, во Франции политический порядок обеспечивался военным абсолютизмом и централизованным контролем. В Великобритании для достижения той же цели оберегали автономию местных элит, чья деятельность обеспечивала достижение общего блага, хотя они и преследовали собственные интересы. В результате, столкнувшись с какой-либо проблемой в поддержании промышленного порядка, французы в первую очередь думали о таких решениях, которые предполагали усиление государственного контроля. Когда с новой проблемой сталкивались в Великобритании, там рассматривались только решения, предполагавшие достижение общего блага через установление связи между интересами хозяйственных акторов и интересами общества. В этих странах меры по обеспечению порядка и роста в сфере хозяйства строились на основе тех же представлений о причинноследственных связях, что в символическом виде закрепились как источник политического порядка.

По мере того как уже апробированные решения индустриальных проблем применялись к новым проблемам, они социально конструировались как эффективные. Например, в штатах Новой Англии были созданы арбитражные регулирующие агентства, призванные контролировать деятельность фирм в жизненно важных для государства отраслях. Вскоре это решение переняли другие штаты, а затем и федеральное правительство учредило Комиссию по торговле между штатами ${ }^{3}$, организованную по образцу этих агентств. В Великобритании во второй четверти XIX века возникли инспекции по регулированию дюжины отраслей промышленности, в том числе железнодорожного строительства. Этот процесс воспроизводства содействовал артикуляции ключевых принципов промышленного порядка и рациональности: в каждой стране стремились обобщить принципы, лежащие в основе существующих политик, с тем чтобы использовать их при разработке решений для возникающих новых проблем.

Как показывает история, причиной пересмотра промышленной политики могло стать либо отсутствие ожидаемого результата (например, расхищение государственных средств, направляемых на развитие железных дорог в США), либо то, что заложенные причинно-следственные связи не подтверждались на практике (например, в Великобритании потерпела неудачу попытка повысить уровень безопасности, предавая огласке информацию о чрезвычайных происшествиях). В обоих случаях создавалась новая политическая стратегия. Однако после того, как та или иная политика и предполагаемые ею причинно-следственные связи институционализировались, они сами начинали влиять на выбор политики в дальнейшем. В Великобритании инспекции как средство управления развитием промышленности не сразу вышли на первый план, а впоследствии и вовсе уступили место более активному вмешательству государства в экономику, но на пике своей популярности инспекции были созданы почти в каждой отрасли промышленности. США экспериментировали с политикой активного содействия экономическому росту на уровне штата и муниципалитета прежде, чем отдать предпочтение политике федерального контроля над сохранением ценовой конкуренции; но в дальнейшем эта стратегия применялась в регулировании всех секторов промышленности.

3 То же, что Комитет по межштатному транспорту и торговле (Interstate Commerce Commission, ICC) - федеральное агентство, созданное в силу закона «О торговле между штатами» 1887 г.; предназначено для регулирования размера тарифов и качества услуг при транспортировке товаров между штатами. 
В целом я утверждаю, что именно культура определяет восприятие проблем и их решения; в частности, от характеристик политической культуры зависит, какими будут возникающие стратегии промышленной политики. Этот процесс сложен, а его результаты не предопределены — каждая нация могла выбрать иной путь. Тем не менее воздействие политической культуры можно обнаружить на всех этапах развития политики в сфере железных дорог. Подробнее ход событий в отдельных странах будет рассмотрен в следующих главах, но общая схема возникновения парадигм промышленной политики может быть приведена и в данной главе. При этом стоит отметить, что стратегии промышленной политики развивались тем же курсом в ряде других отраслей. Я изучаю именно железные дороги, потому что эта отрасль возникла раньше, нежели сформировались современные парадигмы промышленной политики, и в железнодорожной отрасли политика складывалась в то же самое время, когда возникали общие парадигмы политики (в 1825-1900 гг.), а также потому, что история регулирования столь важной отрасли и столетие спустя предоставляет исследователю достаточно материала для работы.

\section{Политическая культура}

Моя аргументация начинается с анализа политической культуры. К 1825 г. во всех рассматриваемых странах сложилась собственная политическая культура, объединяющая практики и приписываемые им смыслы. Идеологические постулаты в защиту той или иной политической практики (первоначально возникшей вследствие определённого стечения обстоятельств) наделяли её собственным смыслом, и в результате параметры существующего государственного устройства социально конструировались как необходимые для поддержания политического порядка. В каждой из стран особенности существующего государственного устройства преподносились как конкретный инструмент поддержания политического порядка; со временем закреплялось представление о том, что именно этот способ и есть единственно возможный. И в каждой стране государственные структуры по-разному определяли факторы, угрожающие политическому порядку. В США принцип местного самоуправления (сложившийся в условиях необходимости управлять разбросанными по огромной территории поселениями колонистов) был возведён в ранг теории демократического управления и формально закреплён в Конституции. Источником политического порядка был суверенитет местного сообщества. Во Франции и монархисты, и сторонники республики превозносили централизованные институты государства как способ сохранить политический порядок и выработали политическую философию, в рамках которой централизация выступала неотъемлемой частью как монархического, так и демократического способа правления. С точки зрения французов, демократия невозможна без сильного центра, способного предотвратить появление властных группировок, препятствующих реализации политических прав граждан республики. Источником политического порядка, таким образом, считалось суверенное государство. В ходе Английской революции XVII века поддержку получила система управления «корольв-парламенте» (King-in-Parliament), при которой каждый представитель высшей аристократии имел свою сферу влияния. За этой системой - за трудами британских политических философов, сформулировавших теорию минималистского государства, - был закреплён статус опоры политического порядка и свободы, источник которых видели в сохранении независимости индивида.

Так ключевая логика политического порядка оказалась встроена в институты государства. В следующих главах я покажу, что в каждой из рассматриваемых мною стран можно выявить единый принцип, задающий такие разнородные параметры государственного устройства, как локус государственной власти, степень концентрации власти, организация правовой системы, работа государственного аппарата и независимых экспертов, а также фискальные возможности государства.

\section{Возникновение промышленной культуры}

Национальные промышленные стратегии в области железнодорожного строительства стали результатом попыток государства решить воспринимаемые проблемы отрасли в четырёх функциональных 
сферах: планирование, финансирование, техническая и управленческая координация, а также ценообразование и конкуренция. В каждой стране новые промышленные политики воспроизводили в сфере промышленности те процессы и практики, что были социально сконструированы как конституирующие по отношению к политическому порядку. И в каждой стране промышленные политики стремились изжить те процессы и практики, которые были сконструированы как подрывающие политический порядок. Разрабатывая политику стимулирования экономического роста, эти страны создали культурно обусловленные конструкты промышленной рациональности, изоморфные подобным конструктам в сфере политического порядка. Политики формировали институты промышленности, руководствуясь привычными представлениями о принципах социальной организации.

\section{США}

В Соединённых Штатах местное самоуправление считалось необходимым условием политического порядка; централизованная же политическая власть рассматривалось как угроза. На начальном этапе существования отрасли политика по регулированию железных дорог предполагала её активную поддержку со стороны правительств штатов и местной власти, которые напрямую влияли на планирование маршрутов, стремясь содействовать строительству дороги на своей территории, чтобы обеспечить рост экономики региона. Правительства поощряли строительство железных дорог, предлагая частным агентам земли и капитал. Финансирование строительства также осуществляли в первую очередь правительства штата и муниципалитета, что позволяло создавать финансовые стимулы к участию в строительстве. Федеральное правительство даже некоторое время финансировало строительство трансконтинентальных железных дорог, но распространение взяточничества вскоре положило конец активному участию правительств всех уровней в развитии данной отрасли. В США и Европе владельцы железных дорог самостоятельно обеспечивали техническую и управленческую координацию в таких вопросах, как выбор ширины рельсовой колеи, определение временны́х зон, установление правил техники безопасности и составление расписания движения поездов. Американское правительство изначально постановило не вмешиваться в работу железных дорог, и решение всех этих вопросов было оставлено на усмотрение частных собственников. Наконец, в сфере ценообразования и конкуренции правительства американских штатов и местные власти сначала предоставили владельцев железных дорог самим себе, однако когда концентрация власти в отрасли начала расти, правительства озаботились защитой экономических свобод американцев от её угроз и начали насаждать ценовую конкуренцию. Чтобы поддерживать свободный рынок, правительства штатов и местные органы власти законодательно запретили дискриминационные расценки, установление твёрдых цен, создание картелей и все многочисленные приёмы, которые владельцы крупных железных дорог использовали, чтобы ограничить конкуренцию. К концу XIX века целью промышленной политики государства стало поддержание рыночных механизмов; чтобы гарантировать экономические свободы и обеспечить экономический рост, все прочие формы вмешательства государства в хозяйственную жизнь исключались.

\section{Франция}

Конституирующим фактором политического порядка во Франции считалось централизованное государство, управляющее обществом; избыточное влияние частных собственников расценивалось как деструктивное. Многие французы ожидали, что правительство национализирует железные дороги, однако этого не произошло из-за финансовых ограничений. Тем не менее государство нацелилось на установление жёсткого контроля над отраслью. Как только во Франции осознали всю важность железных дорог, право планировать размещение железнодорожной сети перешло к центральному бюрократическому аппарату государства. Всем попыткам местных властей и частных владельцев повлиять на планирование маршрутов стойко противостояли государственные инженеры, поскольку такое вмешательство рассматривалось как потенциальная угроза рационально организованной схеме железных дорог. Финансирование железных дорог также зависело от централизованного государства: оно обе- 
спечивало выделение всех участков под строительство и значительную часть капиталовложений, а также гарантировало выплату дивидендов с частного капитала, привлечение строительных фондов и в тяжёлые времена непосредственно осуществляло организацию и финансирование строительства, чтобы не прерывать развитие железнодорожной сети. Государственный аппарат полностью контролировал разработку строительных и эксплуатационных норм: государственные специалисты устанавливали тарифы, определяли процедуры управления, проектировали мосты и тоннели, разрабатывали технические условия на производство строительных работ и подвижной состав. Ситуация, сложившаяся во Франции в сфере ценообразования и конкурентной политики, уникальна: здесь государство принудило владельцев независимых железных дорог к слияниям, создав в конечном счёте шесть региональных железнодорожных монополий, возникновение которых и исключительное право на установление цен позволили устранить конкуренцию между участниками отрасли. В целом политика государства была нацелена на централизованное управление отраслью и предотвращение вмешательства частных инвесторов, чьи интересы могли нарушить территориальную связанность и эффективность национальной железнодорожной сети.

\section{Великобритания}

Конституирующим фактором политического порядка в Великобритании считалась политическая автономия индивида; господство же государства или частных лиц над отдельным человеком (суверенным гражданином) полагали деструктивным. Британская политика принципиально отличалась от политики других европейских стран. Планированием занимались только частные инвесторы. Местная власть и центральный государственный аппарат не имели права вмешиваться в планирование маршрутов частных железных дорог, за исключением случаев, когда необходимо было защитить местных землевладельцев от чрезмерно масштабного отчуждения участков. Финансирование железнодорожного строительства также было полностью частным. В парламенте ни разу не поднимался вопрос о государственной финансовой поддержке британских железных дорог. Технологические нормативы и стандарты строительных работ в целом тоже устанавливали сами владельцы железных дорог; вмешательство государства ограничивалось лишь контролем над обеспечением безопасности перевозок и установлением тарифов на проезд пассажиров в вагонах третьего класса во имя защиты суверенных граждан Великобритании от произвола концентрированного капитала. Британская политика в отношении цен и конкуренции защищала фирмы от концентрированной политической власти (необоснованного вмешательства государства) и от концентрированной экономической власти (хищнически настроенных владельцев крупных железных дорог). Цель конкурентной политики состояла в том, чтобы препятствовать слияниям, защищая тем самым автономию мелких фирм, и поощрять картели, укреплявшие положение мелких фирм. В этом отношении британская политика значительно отличалась от политики США. Решением парламента контроль над отраслью был передан её участникам, а защита фирм осуществлялась путём ослабления рыночных механизмов, то есть Великобритания защищала фирмы, а не конкуренцию на рынке.

Таким образом, в каждой стране промышленная политика создавалась для того, чтобы стимулировать в промышленности именно те процессы, которые рассматривались как необходимые для поддержания порядка. В этой главе я ставил перед собой довольно скромную задачу и надеюсь, что мне удалось показать существование изоморфизма между сферами политики и промышленности, наличие которого, во-первых, поразительно само по себе (учитывая всё разнообразие созданных людьми институциональных систем) и, во-вторых, не находит объяснения ни в одной из основных теоретических парадигм.

Чтобы сделать понятным отличие моей позиции от других подходов, в этой главе я высказывался весьма полемично. Однако я вовсе не хочу сказать, что политика, экономика и институты суть лишь эпифеномены современного мира, но хочу привлечь внимание читателя к тому, что эти сферы далеко не 
столь очевидны, как это обычно предполагается в реалистических подходах. Экономической теории принадлежит полезное наблюдение о существовании границ рационального поведения, однако эмпирические свидетельства опровергают базовое теоретическое допущение экономической теории о существовании набора универсальных правил, которым подчиняется каждая система хозяйства. Экономисты, занимающиеся такими непростыми темами, как происхождение логик хозяйственных систем и причины различий между ними, могут предложить много интересных идей. Политологи заслуживают одобрения за систематическое изучение борьбы групп интересов, но они склонны принимать как данность наличие конкретных групп, а также представления этих групп о своих интересах. Политологи, исследующие возникновение групп и то, как у их представителей складывается понимание своих интересов, могут дать ответы и на другие фундаментальные вопросы. Сторонники институционального (стейтистского) подхода очень правильно обращают внимание на проблему воспроизводства институтов, но они же с досадным упорством выносят за скобки трудный вопрос о том, как возникают институционализированные конструкты реальности и как они воздействуют на принятие политических решений. В рамках одной книги невозможно исследовать роль институционализированных культурных смыслов в этих трёх сферах. Однако я надеюсь, что мне удастся показать недостаточное освещение роли смысла институтов в исследованиях политики.

\section{Заключение}

Говоря в целом, именно представления американских, французских и британских политиков о причинно-следственных связях определили, какими будут современные стратегии промышленной политики в США, во Франции и в Великобритании. Это происходило потому, что нации наделяли смыслом существующие государственные институты, рассматривая их как инструменты для претворения в жизнь модернистского проекта прогресса, а также в силу того, что акторы подходили к решению новых проблем, опираясь на привычную логику, заложенную в уже имеющихся институтах. В данном обзоре описано состояние политических культур трёх стран на пороге индустриальной эры и показано, что в каждой стране промышленная культура развивалась по образцу политической культуры. Эти параллели ни в коем случае не случайны. Во всех странах развитие национальных парадигм промышленной политики было постепенным и эволюционным процессом, в котором допускаются фальстарты, инновации, ошибки и смены парадигмы. Эволюция парадигм политики продолжается и сейчас, а сами парадигмы по-прежнему зависят от того, каких концепций эффективности придерживаются нации и международные организации. Конечно, политическая культура прошлого вовсе не предопределяет то, какой будет сегодняшняя парадигма политики, однако в каждой из рассмотренных нами стран формирование парадигмы политики было эволюционным процессом и зависело от национальных представлений о порядке и эффективности. В следующих главах я постараюсь показать, что основные принципы экономической эффективности и рациональности, то есть ключевые идеи о том, как функционируют капитализм и современность в целом, являются не результатом следования неким внесоциальным экономическим заповедям, а продуктами социальных и исторических сил, вполне поддающихся изучению.

\section{Лumepamypa}

Anderson B. 1983. Imagined Communities: Reflections on the Origin and Spread of Nationalism. London: Verso.

Ashcraft R. 1986. Revolutionary Politics and Locke's Two Treatises of Government. Princeton: Princeton University Press.

Bachrach P., Baratz M. S. 1963. Decisions and Nondecisions: An Analytic Framework. American Political Science Review. 57: 632-642. 
Berger P., Luckmann Th. 1966. The Social Construction of Reality: A Treatise on the Sociology of Knowledge. Garden City: Doubleday; см. также рус. пер.: Бергер П., Лукман Т. 1995. Социальное конструирование реальности. М.: Медиум.

Bloor D. 1976. Knowledge and Social Imagery. London: Routledge.

Bowles S., Gintis H. 1986. Democracy and Capitalism: Property, Community, and the Contradictions of Modern Social Thought. New York: Basic.

Commons J. R. 1934. Institutional Economics: Its Place in Political Economy. New York: Macmillan.

DiMaggio P. J., Powell W. 1983. The Iron Cage Revisited: Institutional Isomorphism and Collective Rationality in Organizational Fields. American Sociological Review. 48: 147-60; см. также рус. пер.: Димаджио П. Дж., Пауэлл У. В. 2010. Новый взгляд на «железную клетку»: институциональный изоморфизм и коллективная рациональность в организационных полях. Экономическая социология. 11 (1): 34-56. URL: http://ecsoc.hse.ru/issues/2010-11-1/index.html

DiMaggio P. J., Powell W. W. 1991. Introduction. In: Powell W. W., DiMaggio P. J. (eds). The New Institutionalism in Organizational Analysis. Chicago: University of Chicago Press; 1-40.

Douglas M. 1986. How Institutions Think. Syracuse, NY: Syracuse University Press.

Dyson K. 1983. The Cutural, Ideological and Structural Context. In: Dyson K., Wilks S. (eds). Industrial Crisis: A Comparative Study of the State and Industry. Oxford: Martin Robinson; 26-66.

Eisenstadt S. N., Abitbol M., Chazan N. 1987. Cultural Premises, Political Structures and Dynamics. International Political Science Review. 8: 291-306.

Elster J. 1989. The Cement of Society: A Study of Social Order. New York: Cambridge University Press.

Gerschenkron A. 1962. Economic Backwardness in Historical Perspective. Cambridge: Harvard University Press.

Granovetter M. 1985. Economic Action and Social Structure: The Problem of Embeddedness. American Journal of Sociology. 91: 481-510; см. также рус. пер.: Грановеттер М. 2002. Экономическое действие и социальная структура: проблема укоренённости. Экономическая сочиология. 3 (3): 44-58. URL: http://ecsoc.hse.ru/issues/2002-3-3/index.html

Hall P. A. 1989. The Political Power of Economic Ideas: Keynesianism Across Nations. Princeton, NJ: Princeton University Press.

Hall P. A. 1992. The Movement from Keynesianism to Monetarism: Institutional Analysis and British Economic Policy in the 1970s. In: Steinmo S., Thelen K., Longstreth F. Historical Institutionalism in Comparative Politics: State, Society, and Economy. New York: Cambridge University Press; 90-113.

Hamilton G. G., Biggart N. W. 1988. Market, Culture, and Authority: A Comparative Analysis of Management and Organization in the Far East. American Journal of Sociology. 94: S52-S94.

Hintze O. 1975 (reprints). The Historical Essays of Otto Hintze / Felix Gilbert (ed.). New York: Oxford University Press. 
Hirschman A. O. 1977. The Passions and the Interests: Political Arguments for Capitalism before its Triumph. Princeton: Princeton University Press.

Ikenberry G. J. 1988. Reasons of State: Oil Politics and the Capacities of American Government. Ithaca: Cornell University Press.

Jepperson R. 1991. Institutions, Institutional Effects, and Institutionalism. In: Powell W., DiMaggio P. (eds). The New Institutionalism in Organizational Analysis. Chicago: University of Chicago Press; 143-163.

Krasner St. D. 1978. Defending the National Interest: Raw Materials Investments and U.S. Foreign Policy. Princeton: Princeton University Press.

Krasner St. D. (ed.). 1983. International Regimes. Ithaca: Cornell University Press.

Krasner St. D. 1993. Westphalia and All That. In: Goldstein J., Keohane R. O. (eds). Ideas and Foreign Policy: Beliefs, Institutions, and Political Change. New York: Cornell University Press; 235-264.

Latour B. 1992. One More Turn After the Social Turn. Mimeo. Paris: CSI-Ecole des Mines.

Lipset S. M., Rokkan St. (eds). 1967. Party Systems and Voter Alignments: Cross-National Perspectives. New York: Free Press.

Lukes St. 1974. Power: A Radical View. London: Oxford University Press.

Meyer J. W., Boli J., Thomas G. M. 1987. Ontology and Rationalization in the Western Cultural Account. In: Thomas G. M. et al. (eds). Institutional Structure: Constituting State, Society, and the Individual. Beverly Hills: Sage; 12-37.

Meyer J. W., Rowan B. 1977. Institutionalized Organizations: Formal Structure as Myth and Ceremony. American Journal of Sociology. 83: 340-363; см. также рус. пер.: Мейер Дж., Роуэн Б. 2011. Институционализированные организации: формальная структура как миф и церемониал. Экономическая соииология. 12 (1): 43-67. URL: http://ecsoc.hse.ru/issues/2011-12-1/index.html

North D. 1981. Structure and Change in Economic History. New York: Norton.

Parsons T. 1951. The Social System. Glencoe, I11.: Free Press; см. также рус. пер.: Парсонс Т. 2002. O coциальных системах. М.: Академический проект.

Parsons T. 1971. The System of Modern Societies. Englewood Cliffs, NJ: Prentice Hall; см. также рус. пер.: Парсонс Т. 1997. Система современных обществ. М.: Аспект-Пресс.

Ruggie J. G. 1993. Territoriality and Beyond: Problematizing Modernity in International Relations. International Organization. 47 (1): 139-174.

Scott W. R. 1987. The Adolescence of Institutional Theory. Administrative Science Quarterly. 32: 493-511.

Scott W. R. 1992. Institutions and Organizations: Toward a Theoretical Synthesis. Mimeo. Stanford: Stanford University; Department of Sociology. 
Sewell W. H., Jr. 1985. Ideologies and Social Revolutions: Reflections on the French Case. Journal of Modern History. 57: 57-85.

Sewell W. H., Jr. 1992. A Theory of Structure: Duality, Agency, and Transformation. American Journal of Sociology. 98: 1-29.

Shonfield A. 1965. Modern Capitalism. London: Oxford University Press.

Skocpol Th., Finegold K. 1982. State Capacity and Economic Intervention in the Early New Deal. Political Science Quarterly. 97: 255-278.

Skowronek St. 1982. Building a New American State: The Expansion of National Administrative Capacities: 1877-1920. New York: Cambridge University Press.

Thomas G. M., Meyer J. W. 1984. The Expansion of the State. Annual Review of Sociology.10: 461-482.

Tilly Ch. (ed.). 1975. The Formation of National States in Western Europe. Princeton: Princeton University Press.

Veblen Th. 1904. The Theory of Business Enterprise. New York: Scribner's; см. также рус. пер.: Веблен Т. 2007. Теория делового предприятия. М.: Дело.

Villedeuil L. de. 1903. Bibliographic des Chemins de Fer. Paris: Villedeuil.

Weber M. 1978. Economy and Society: 2 Vol. / Roth G., Wittich C. (eds). Berkeley: University of California Press.

White H. C. 1988. Varieties of Markets. In: Wellman B., Berkowitz St. D. (eds). Social Structures: A Network Approach. New York: Cambridge University Press; 226-260.

Wuthnow R. 1987. Meaning and Moral Order: Explorations in Cultural Analysis. Berkeley: University of California Press.

Zelizer V. A. 1988. Beyond the Polemics of the Market: Establishing a Theoretical and Empirical Agenda. Sociological Forum. 4: 614-634.

Zelizer V. 1993. Making Multiple Monies. In: Swedberg R. (ed.). Explorations in Economic Sociology. New York: Russell Sage Foundation; 193-212.

Zucker L. G. 1977. The Role of Institutionalization in Cultural Persistence. American Sociological Review. 42: 726-743.

Zysman J. 1983. Governments, Markets, and Growth: Financial Systems and the Politics of Industrial Change. Ithaca, Cornell University Press. 


\title{
РАСШИРЕНИЕ ГРАНИЦ
}

\author{
Дж. Мокир, Г.-И. Фотх
}

\section{Экономический рост в Европе в 1700-1870 гг.: теория и фактические свидетельства}

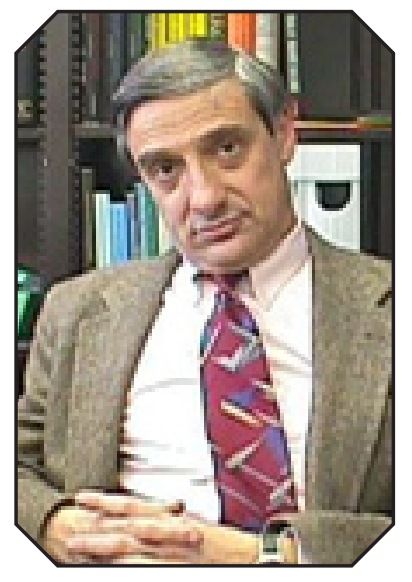

\section{МОКИР Джоэль}

(Mokyr, Joel) просрессор экономической истории факультета экономики Северо-Западного университета (Эванстон, США).

Email: j-mokyr@ northwestern.edu
В отличие от большинства работ по экономической истории Нового и Новейтего времени, в которых рассматривается развитие отдельных стран, в «Кембриджской экономической истории Европы Нового и Новейшего времени» период, охватывающий 1700-1870 г2., переосмысливается как единое панъевропейское явление, при этом материал организован по нескольким крупным темам, а не по отдельным государствам. В томе I рассматривается переход к современному экономическому росту, начавшийся в Англии и приблизительно к 1870 г. распространившийся на другие части Западной Европьл. Каждая глава написана международной командой авторов, проанализировавших развитие трёх важнейших регионов - Северной Европь, Южной Европь и Центральной и Восточной Европьл. В иентре внимания авторов первого тома находятся важнейшие темы экономической истории Нового и Новейшего времени, в том числе торговля, урбанизация, совокупный экономический рост, важнейшие сферы экономики (сельское хозяйство, промышленность и услуги), а также повышение уровня жизни населения и распределение доходов.

Журнал публикует работу Джсоля Мокира и Ганса-Иоахима Фотха «Экономический рост в Европе в 1700-1870 г2.: теория и фактические свидетельства» из первого тома «Кембриджской экономической истории Европь Нового и Новейшего времени». В ней представлены обобщённые результаты современных исследований, посвящённых объяснению экономического роста.

Ключевые слова: экономический рост; экономическая история; институты; человеческий капитал; культура.

\section{Часть первая}

\section{Агрегированный рост и экономические циклы}

\section{Глава 1}

Экономический рост в Европе в 1700-1870 г2.: теория и фрактические свидетельства

Сегодня обычные жители экономически развитых стран получают доходы, превосходящие те, которыми на протяжении большей части истории человечества располагали богатейшие представители элит. В 1930 г. Джон Мейнард Кейнс несколько скептично заметил, что экономические проблемы 


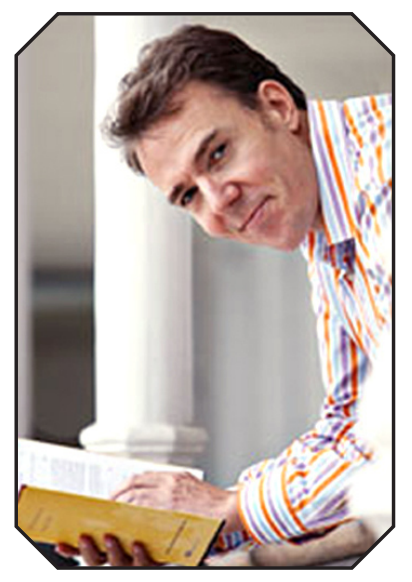

ФОТХ Ганс-Иоахим

(Voth, Hans-Joachim) профессор и научный сотрудник фракультета экономики Университета Помпеу Фабра (Барселона, Испания).

Email: jvoth@crei.cat

Перевод с англ. Юрия Каптуревского.

Источник: Мокир Дж., Фотх Г.-И. 2012.

Экономический рост в Европе в 1700-1870 гг:: теория и фактические свидетельства.

В сб.: Бродберри Ст., О'Рурк К. (ред.).

Кембриджская

экономическая история

Европы Нового и Новейшего времени. Том 1: 1700-1870 г2. М.: Изд-во Института Гайдара. человечества уже решены, по крайней мере в Европе и Северной Америке [Keynes 1930]. Исчезла угроза голода. Чистая одежда, крыша над головой и тепло перестали быть роскошью и воспринимались как предметы первой необходимости. К 1870 г. процесс развития, благодаря которому в конечном счёте было создано всеобщее богатство, уже набрал полный ход. В предлагаемой главе обобщаются результаты недавних экономических исследований в области теории роста, позволяющие ответить на вопрос, как человечеству удалось спастись от «неприятной, жестокой и короткой», по словам Томаса Гоббса, жизни. Предлагаемые интерпретации сопоставляются с известными историческими свидетельствами и последними научными результатами экономических историков. Самое пристальное внимание уделяется четырём областям - демографии, институтам, человеческому капиталу и технологии. В заключение мы высказываем предположения, которым ещё предстоит пройти проверку будущими исследованиями.

\section{Теоретические подходы}

В конце 1980-х — начале 1990-х гг. фокус внимания специалистов по макроэкономике начинает перемещаться с экономических циклов к детерминантам долгосрочного экономического роста. Авторы научных публикаций об эндогенном росте предлагали различные объяснения того факта, что в некоторых странах мира экономическое развитие происходило гораздо быстрее, чем в других. В большинстве своём предлагаемые модели применялись к периоду, наступившему после окончания Второй мировой войны. В результате произошло возвращение к классическому аргументу, выдвинутому Саймоном Кузнецом: в случае обратной экстраполяции текущих темпов роста мы придём к выводу, что в начале Нового времени и в предшествовавший ему период доходы находились на абсурдно низком уровне [Kuznets 1955; 1974]. Следовательно, началу роста современного типа должен был предшествовать продолжительный период стагнации. Возникает вопрос: что обусловило фазовый переход от мира очень низких или нулевых темпов роста к новому миру быстрого и устойчивого роста?

Начиная с 1990-х гг. учёные пытаются создать всеобъемлющую теорию, позволяющую охватить как медленный рост, так и переход к быстро увеличивающимся среднедушевым доходам, то есть выработать унифицированную модель роста (unified growth model). И сегодня эта научная область пользуется повышенным вниманием исследователей. К важнейшим её темам относятся демография, влияние институтов, человеческий капитал и культуpa, а также роль технологии. Прежде всего, мы предложим обзор некоторых наиболее значительных достижений в данной области, представленных в научной литературе. В основной части главы проводится сравнение теоретических предсказаний и главных открытых специалистами по экономической истории фактических свидетельств. В заключение выдвигается ряд предположений относительно возможного продвижения дальнейших исследований в рассматриваемой нами области.

В ранних моделях в рамках унифицированной теории роста (например, [Kremer 1993]) переход от стагнации к росту был представлен как процесс длительного постепенного ускорения темпов роста. Как и в некоторых дру- 
гих публикациях, посвящённых эндогенному росту, в модели Кремера предполагается, что увеличение численности населения ведёт к ускорению технологических изменений, так как вероятность выдвижения неким индивидом той или иной блестящей идеи является относительно постоянной величиной. Поскольку эти идеи никак не соперничают, происходит ускорение роста. Кремер показал, что некоторые базисные предсказания, сделанные на основе этой — достаточно простой — модели роста, подтверждаются как при анализе временных рядов, так и при кросс-секционном анализе. Располагая данными о текущей численности населения, мы можем предсказать темпы его роста за миллион лет до н. э. Кроме того, географически отделённые друг от друга экономические единицы, занимающие значительные территории, продуцируют большее по численности население и более высокую его плотность. Поскольку рост численности населения и технологическое развитие происходят одновременно, в модели Кремера отсутствует состояние равновесия. Для того чтобы избежать взрывного роста всех переменных, необходим демографический переход, когда при достижении некоего порогового уровня увеличение доходов ведёт к снижению рождаемости.

Напротив, в моделях экзогенного роста технология «просто случается», а решения об её принятии не являются эксплицитными. Размер сам по себе не оказывает влияния ни на технологию, ни на изменение производительности. Один из примеров приложения концепции экзогенного роста к изучению перехода к самоподдерживающемуся устойчивому росту — модель перехода «от Мальтуса к Солоу» Г. Хансена и Э. Прескотта [Hansen, Prescott 2002]. Она основывается на допущении об экзогенной данности и постоянстве технологических изменений как в способе производства с использованием земли (при убывающей отдаче), так и в способе производства, не предполагающем оного. Первоначально применяется только мальтузианская технология. В рассматриваемой модели в каждом поколении, продолжительность жизни которого составляет 35 лет, производительность в «мальтузианском секторе» (то есть в сельском хозяйстве, в условиях убывающей предельной отдачи труда) увеличивается на $3,2 \%$, в то время как в «секторе Солоу» (где все факторы производства являются воспроизводимыми) - на $52 \%$. В конечном счёте, поскольку производительность неиспользуемой технологии экспоненциально возрастает, технология Солоу становится конкурентоспособной и принимается. В этих условиях промышленная революция является неизбежной, а её наступление зависит только от используемых при градуировке различных темпов роста производительности.

Ко второму классу моделей, для которых размер имеет значение, также относятся те из них, где технологические изменения рассматриваются как экзогенные. Но в этом случае внимание исследователей сосредоточено на условиях, позволяющих применить новые технологии. Авторы первоначальных моделей, следуя традиции, заложенной К. Мёрфи, А. Шлейфером и Р. Вишну [Murphy, Shleifer, Vishny 1989], опирались на воздействие спроса и соответственно размеров экономик для обоснования периода, когда мог произойти «большой скачок». Приверженцы этой концепции, следуя П. Розенштейну-Родану, понимают под «большим скачком» одновременный переход на новые технологии сразу во многих секторах экономики. Для того чтобы покрыть постоянные издержки, ассоциирующиеся с внедрением новых технологий производства, уровень спроса должен быть достаточно высок. Зачастую это возможно только в случае, если индустриализация охватывает целый ряд отраслей. По мере увеличения совокупного выпуска вероятность такого развития событий возрастает. Один из выводов применения рассматриваемых моделей состоит в том, что индустриализация могла бы начаться задолго до того, как она развернулась в полную силу: если бы все приняли решение о более раннем инвестировании в технологии, связанные со значительными постоянными издержками, то прибыли были бы достаточно высокими, чтобы оправдать расходы. Новые технологические знания сами по себе не обязательно ведут к повышению производительности. Таким образом, отсутствие координации может подорвать переход к современной технологии. 
В моделях, где принятие решения зависит от диверсификации рисков, ключевую роль играют также высокие постоянные издержки и неделимость. Д. Асемоглу и Ф. Зилиботти представили модель, основанную на противоречии между требованиями производства и инвестициями домашних хозяйств [Acemoglu, Zilibotti 1997]. Производственные проекты, предусматривающие использование новых технологий, требуют высоких расходов на создание нового предприятия. В то же время домашние хозяйства стремятся к диверсификации своих инвестиций с целью минимизации рисков. В силу этого первоначально инвестиции в новые продуктивные технологии находятся на очень низком уровне, равно как и производительность. Ситуация изменяется по мере того, как домашние хозяйства становятся богаче: объем сбережений относительно требований, предъявляемых новыми технологиями к капиталу, в достаточной степени увеличивается, что позволяет домохозяйствам не «складывать все яйца в одну корзину». По мере того как индустриализация набирает ход, она начинает генерировать средства, обеспечивающие её собственное развитие. Возникает своеобразная лотерея. В зависимости от того, насколько им повезло в первом раунде, две первоначально идентичные экономики могут встать на принципиально отличные друг от друга пути развития. В модели Асемоглу и Зилиботти подчёркивается, что домашние хозяйства не принимают во внимание воздействие своих инвестиционных решений на совокупную производительность. Существование возможности индустриализации не означает, что эта возможность будет использована. Модель включает стохастический компонент: в определённой степени индустриализация может быть результатом удачного стечения обстоятельств. Одно из следствий присутствия этого элемента заключается в том, что не каждый компонент реальной индустриализации наполнен смыслом, и возможно, что стране, которая опередила остальных, просто повезло ${ }^{1}$.

Во многих унифицированных моделях роста накопление человеческого капитала связывается с технологией и расширением возможностей продуцирования новых идей благодаря росту численности населения. В работах такого рода обосновывается положение, согласно которому переход к современному типу роста сопровождается увеличивающимся значением человеческого капитала [Becker, Barro 1988; Becker, Murphy, Tamura 1990; Lucas 2002]. По мнению О. Галора и Д. Вейла, связь между человеческим капиталом и технологическими изменениями является краеугольным камнем перехода к быстромy росту [Galor, Weil 2000]. Эти исследователи утверждают, что выход из стагнации осуществляется в два шага: сначала происходит переход от мальтузианского к постмальтузианскому состоянию и лишь затем - к режиму современного роста. В соответствии с ключевым допущением Галора и Вейла, по мере ускорения технологических изменений возрастает ценность человеческого капитала, что позволяет людям приспособиться к переменам, происходящим на рабочих местах. Технологические изменения ускоряются, поскольку больше людей продуцируют большее количество идей в течение продолжительного мальтузианского периода. Поскольку доходы увеличиваются быстрее, чем численность населения, среднедушевой доход пусть и очень медленно, но возрастает. В конце концов инвестиции родителей в человеческий капитал своих отпрысков повышаются, что, в свою очередь, обусловливает ускоренное расширение круга доступных знаний. Бо́льшие доходы позволяют иметь и бо́льшее количество детей в семьях. В то же самое время возрастающая ценность человеческого капитала продуцирует стимулы к повышению «качества» детей и сокращению их количества. На первоначальном этапе роста современного типа доминирует эффект дохода, что ведёт к увеличению рождаемости; впоследствии на первый план выходит эффект замещения, и показатели рождаемости снижаются.

М. Червеллати и У. Сунде [Cervellati, Sunde 2005], а также Д. Делакруа [De la Croix 2008] оценивают ситуацию несколько иначе, утверждая, что вместе с ростом производительности быстро увеличивается ожидаемая продолжительность жизни. В результате, по мере того как горизонт окупаемости отодвигается все дальше, усиливаются стимулы к инвестициям в человеческий капитал. Даже если технологические изменения лишь в малой степени зависят от уровня квалификации работников, запускается самоподдерживающийся процесс улучшения технологий, увеличения ожидаемой продолжительности

1 Впервые высказанная Н. Крафтсом [Crafts 1977], эта идея была предметом плодотворных дебатов историков экономики. 
жизни и повышения объёма инвестиций в человеческий капитал. Р. Боукеккине, Д. Делакруа и Д. Петерс показывают, что увеличивающаяся плотность населения может способствовать распространению грамотности, поскольку происходит удешевление предоставляемых школой услуг [Boucekkine, De la Croix, Peeters 2007]. Ч. Джонс предпринял попытку объединить механизм «население - идеи» и режим прав собственности, позволяющий инноваторам присваивать часть объёма производства [Jones 2001]. Основываясь на своей собственной «градуировке», Джонс приходит к выводу, что единственным важнейшим фактором «взлёта» экономики по окончании XIX века стало более эффективное принуждение к соблюдению прав интеллектуальной собственности, и это создало необходимые стимулы для сферы продуцирования идей.

\section{Некоторые замечания с точки зрения экономической истории}

Во многих унифицированных моделях роста ключевую роль играет положение о связующем характере отношения «население - идеи». Согласуется ли это положение с историческими свидетельствами? Как подчёркивал Крафтс, выводы кросс-секционного межстранового анализа экономического роста в Европе и во всём мире не подтверждаются имеющимися фактами: более крупные страны растут отнюдь не быстрее, чем другие [Crafts 1995]². Это заключение исследователя подкрепляется современными данными: размер той или иной страны мира либо отрицательно связан с показателем ВВП в расчёте на душу населения, либо связь такого рода отсутствует. Этот отрицательный научный результат представляется весьма правдоподобным, поскольку с увеличением размеров страны значение одного из самых устойчивых коррелятов экономического роста - верховенства закона — снижается [Hansson, Olsson 2006]. Даже если мы заменим «население» более релевантными показателями, такими как размер рынка, определяющий уровень спроса на новые товары, данные об экономическом росте Англии и Франции, значительно отличающиеся друг от друга, едва ли будут соответствовать моделям эндогенного роста, в которых делается акцент на размерах ${ }^{3}$. Более того, положению о ключевой роли отношения «население - идеи» противоречит тот факт, что к 1750 г., в преддверии Промышленной революции, Англия в течение вот уже половины столетия находилась в состоянии демографической стагнации. Если бы численность населения действительно играла решающую роль, то как быть с Китаем начального периода Нового времени? Население этой страны увеличилось со 130 млн человек в 1650 г. до 420 млн человек в 1850 г., однако никакой промышленной революции не произошло. Интересный аргумент приводит Дж. Лин [Lin 1995]. Исследователь убеждён, что отношение между размерами населения и технологическими изменениями зависит от источника инноваций. В мире, где новые технологии целиком и полностью основываются на обучении в процессе труда, бо́льшая численность населения предполагает и большее количество инноваций (при условии в равной степени эффективного распространения в большей по численности населения стране). Как только условием прогресса становятся эксперименты и теоретические разработки, преимущество в размере исчезает. По мнению Лина, успехи Китая в период правления династии Сун (960-1279), резко контрастирующие со стагнацией в XVII веке и позже, отражают изменение в источнике инноваций.

2 Поразительно, но до выдвижения на лидирующие экономические позиции Англии наиболее успешными экономиками Европы были города-государства [Hicks 1969: 42], где высокая плотность относительно небольшого по численности населения обусловливала преимущество в решении проблемы создания эффективных коммерческих и финансовых институтов. Размеры рынка не являлись серьезной проблемой в определённой степени потому, что постоянные издержки учреждения институтов были сравнительно небольшими, а городская экономика чаще всего носила открытый характер. Главным источником экономии, обусловленной масштабами производства, была не экономика, но армия. Военная же власть зависела от совокупного дохода и численности населения.

3 Решение этой проблемы попытались предложить авторы других, более поздних моделей в духе Кремера, такие как Ч. Джонс [Jones 2001], который исходит из допущений о возрастающей отдаче в производстве товаров, а также о том, что ряд новых идей является функцией уже существующего их запаса. 
Даже если «размер имеет значение» с точки зрения данных, остаётся вопрос о способах влияния. Большее по численности население (в отсутствие коллапса в среднедушевых доходах) может ассоциироваться с положительными экстерналиями различных типов. Независимо от того, имеет ли размер значение с точки зрения генерирования или принятия новых технологий, в моделях эндогенного роста предполагается, что большие размеры по крайней мере способствуют углублению разделения труда, что само по себе могло содействовать ускорению роста выпуска. В созданной М. Келли «смитианской модели» роста фактором торговой интеграции является усовершенствование транспортной инфраструктуры, благоприятствующей ускорению роста. Автор применяет эту модель к периоду правления династии Сун в Китае. Аналогично в Европе более высокая плотность населения могла генерировать целый ряд положительных экстерналий, отчасти посредством усовершенствований дорог и каналов, отчасти посредством междугородней и международной торговли [Bogart 2005a;, 2005b; Daudin 2007]. В этом смысле нам становится проще объяснить успехи в XVII-XVIII веках средней по размерам, но плотно населённой и интегрированной в международную торговлю Республики Соединённых провинций Нидерландов.

Авторы моделей, следующих традиции «большого скачка», сталкиваются с проблемами, во многом схожими с теми, которые присущи моделям эндогенного роста на основе численности населения. Весь опыт развития Европы после 1700 г. отнюдь не предполагает, что абсолютный размер экономики является хорошим прогнозирующим параметром для времени индустриализации. Бо́льшая часть промышленных проектов никак не впечатляла своими размерами, и создание даже самых крупных текстильных фабрик, если бы оно финансировалось одним человеком, не влекло за собой высокую концентрацию риска. До конца XIX века объём постоянных издержек в промышленности был ограничен. Более того, во время Промышленной революции имела место значительная диверсификация уже существовавщей производственной структуры Англии ${ }^{4}$. В тех случаях, когда речь идёт о производственных технологиях, внедрение которых ассоциируется с высокими постоянными издержками, принятые после 1870 г. решения, возможно, объяснимы в теоретической структуре «большого скачка». Но на тот момент международная торговля уже сделала очень многое для того, чтобы разорвать связь между размером внутренней экономики и возможностью применения технологий. До 1870 г. наиболее крупные постоянные издержки были связаны с созданием инфраструктуры, а не промышленного производства. Об Англии никак нельзя сказать, что инфраструктурные инвестиции - строительство дорог, каналов, портов - страдали от недостатка капиталов. И это несмотря на многочисленные изъяны британской финансовой системы (Закон о дутых компаниях (Bubble Act) ${ }^{5}$ и законы, направленные против ростовщичества, ограничивавшие частное кредитование, а также беспрестанные государственные заимствования на протяжении большей части XVIII века) [Temin, Voth 2008]. В целом финансирование инфраструктурных проектов не вызывало особых трудностей и осуществлялось главным образом представителями местной аристократии.

И наконец, при попытке оценить унифицированные модели роста, в которых основное внимание уделяется различиям в производительности между сельскохозяйственным («традиционным») и промышленным («современным») секторами экономики, такие как модель Хансена и Прескотта [Hansen,

4 Р. Пирсон и Д. Ричардсон показывают, что в период Промышленной революции деятельность типичного предпринимателя носила в высокой степени диверсифицированный характер [Pearson, Richardson 2001]. Авторы уделяют основное внимание не описанию целеустремлённого, всю свою жизнь занятого одним делом владельца-менеджера, а тому, насколько сильно предприниматели того времени были вовлечены в различные побочные предприятия. Например, хозяева фабрик по переработке хлопка и другие владельцы текстильных предприятий из Манчестера, Лидса и Ливерпуля могли одновременно занимать посты директоров страховых, строительных (каналы и дороги) или газовых компаний, банков, а также предприятий других отраслей.

5 Специальный указ Георга I (1719 г.), запрещавший публичную продажу акций компаний, не имевших королевской лицензии. - Примеч. ред. 
Prescott 2002], мы вновь сталкиваемся с эмпирическими трудностями. Когда совокупные темпы роста начали ускоряться, как в сельскохозяйственном, так и в промышленном секторе производительность возрастала, и, по некоторым оценкам, это происходило приблизительно одинаковыми темпами [Crafts 1985]. Заметим, что модель Хансена и Прескотта едва ли пригодна для установления того, какая страна первой начала индустриализацию и почему, поскольку в ней в качестве объекта наблюдения выступает весь мир.

Не следует воспринимать высказанные нами наблюдения как окончательный — положительный или отрицательный - вердикт по отношению к унифицированным моделям роста. Мы лишь попытались объяснить, почему теоретикам, экономистам-прикладникам и экономическим историкам необходимо «копать» ещё глубже - прежде всего в направлении взаимодействий между рождаемостью, человеческим капиталом, институтами и технологиями. Рассмотрению этих взаимосвязей и посвящены следующие разделы главы.

\section{«Исчезновение» Мальтуса}

В начальный период Нового времени в большинстве регионов Европы происходил рост численности населения. Кое-где численность населения превысила уровни, существовавшие до пандемии чумы «Чёрной смерти». В конце XVIII века во многих европейских странах произошло довольно значительное ускорение демографического роста. Однако нельзя не отметить и существование немалых вариаций, поскольку лидировали в данном случае Англия и Ирландия, в то время как Франция в целом избежала резкого скачка. В 1500-1870 гг. экономическое воздействие демографического фактора претерпело заметные изменения. Если первоначально в большинстве частей Европы численность населения была важнейшей детерминантой среднедушевых доходов, то по мере ускорения технологических изменений, после 1800 г., важность этого фактора постепенно снижалась. Нередко теоретики роста называют период до 1750 г. мальтузианской эпохой. В этом разделе мы сначала опишем мальтузианскую модель и произошедшие после 1800 г. изменения во взаимодействиях демографических и экономических факторов, а затем рассмотрим соответствующие фактические свидетельства и суммируем, что мы знаем о том, как давление численности населения перестало быть одной из ключевых экономических переменных.

Мальтузианская модель основывается на двух главных допущениях. Первое из них состоит в том, что рост населения положительно реагирует на рост среднедушевого дохода. В тех случаях, когда заработная плата или доход в расчёте на душу населения сокращаются, происходит снижение рождаемости («превентивная мера»), а показатели смертности возрастают («естественное препятствие»), что на рисунке 1 показано восходящим наклонным графиком рождаемости $B B$ и нисходящим наклонным графиком смертности $D D$. В соответствии со вторым допущением между среднедушевым доходом и численностью населения есть отрицательная связь, обусловленная убывающей отдачей от труда, что показано на рисунке 1 нисходящей кривой предельного продукта труда $M P_{L}$, положение которой inter alia $^{6}$ отображает технологический уровень экономики. Один из наиболее известных примеров, иллюстрирующих выбор между доходами и численностью населения, — пандемия бубонной чумы, известная как «Чёрная смерть». В силу того что население большинства европейских стран сократилось в результате этой эпидемии от одной трети до половины от предкризисных уровней, заработная плата повсеместно выросла. В XIV веке традиционно измеряемый уровень жизни в Англии повысился настолько, что впоследствии аналогичный показатель был достигнут лишь в XIX столетии.

6 Среди других (лат.). - Примеч. ред. 


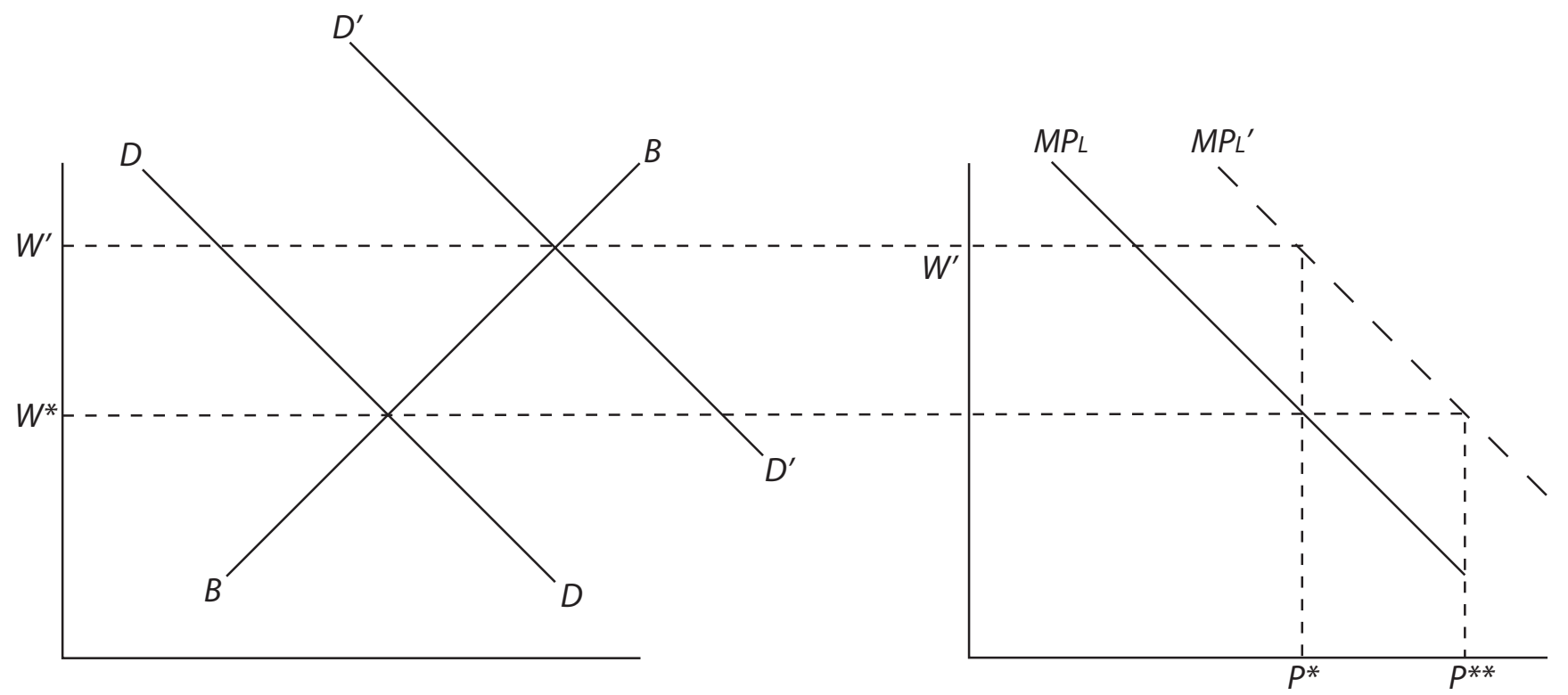

Условные обозначения:

$P$ (Population) - население; $W$ (Wage) - заработная плата; $M P$ (Marginal Product of Labor) — предельный продукт труда; $B B$ (Fertility Schedule) — рождаемость; $D D$ (Mortality Schedule) — смертность.

Рис. 1. Мальтузианская модель роста

Основные допущения мальтузианской модели совместно приводят к выводу, что любые положительные изменения доходов с неизбежностью сходят на нет благодаря увеличению количества появляющихся на свет младенцев. На рисунке 1 графики рождаемости и смертности пересекаются на уровне заработной платы $W^{*}$. Исходя из графика технологий, представленного в правой части рисунка, в этом случае наиболее приемлемая численность населения составляет $P^{*}$. Если в случае временного технологического шока кривая $M P_{L}$ сдвигается вправо — до $M P_{L}{ }^{\prime}$, что обусловливает повышение заработной платы до $W^{\prime}$, показатели смертности снижаются и начинается рост численности населения. В конечном счёте в силу уменьшающейся предельной отдачи заработная плата сокращается до предшествующего уровня (численность населения находится на уровне $P^{* *}$ ). Как однажды заметил Герберт Уэльс, человечество «в бессмысленном и хаотическом воспроизведении обычной убогой жизни транжирило великие дары науки с такой же быстротой, с какой их получало» ${ }^{7}$ [Wells 2009] ${ }^{8}$. Г. Кларк идёт ещё дальше [Clark 2007a]. По его мнению, в 1800 г. типичный житель Англии был ничем не лучше, чем его прародители, жившие на африканских равнинах миллионы лет назад.

Более высокие показатели смертности (отображаются сдвигом графика смертности вправо от $D D$ до $D$ ' $D$ ') подразумевают и более высокий уровень жизни населения. Например, плохие гигиенические условия и ухудшение микробиологической ситуации приведут к повышению доходов в силу увеличения детской смертности. Аналогичное воздействие оказывают и более низкие показатели рождаемости. Общее благосостояние, возможно, не изменится, но доходы живущих возрастут. Европейцы в период раннего Нового времени добивались снижения давления численности населения путём увеличения доли никогда не рожавших женщин. Одновременное повышение возраста вступления в брак привело к дальнейшему сокращению показателей рождаемости. Данная традиция является уникальной для

7 Цит. по: Уэльс Г. 1929. Люди как боги. Л.: Земля и фабрика. URL: http://az.lib.ru/u/uells_g_d/text_1923_men_like_gods. shtml (перевод Л. М. Карнауховой). - Примеч. ред.

8 В соответствии с предположением Галора и Вейла, между изменением уровня доходов и рождаемостью существует определенный временной лаг [Galor, Weil 2000]. Таким образом, ускорение технологических изменений в одном из периодов времени способно генерировать более высокие доходы в следующем периоде. Последовательность положительных шоков приводит к устойчивому росту. Принятие данной гипотезы позволяет нам найти техническое решение проблемы. Однако остаётся открытым вопрос о том, почему на протяжении многих сотен лет реакция рождаемости так и не привела к постепенному уменьшению выгод, связанных с ростом реальной заработной платы. 
Европы. Она охватывала территорию, расположенную к западу от воображаемой линии, проведённой между Петербургом и Триестом [Hajnal 1965]. В других частях мира, в частности в Китае, для того чтобы добиться той же самой цели, практиковалось убийство новорождённых. Но этот метод оказался не слишком эффективным.

Известны два варианта мальтузианской модели. Корни её наиболее сильной формы уходят в классический «железный закон заработной платы» ${ }^{9}$ В отсутствие сдвигов в графиках смертности и рождаемости модель позволяет предсказать стагнацию реальной заработной платы. Без технологических изменений или других шоков на стороне предложения численность населения будет оставаться относительно постоянной. В более слабом варианте мальтузианской модели основой акцент делается на механизмах равновесия, а не на результатах. На демографический рост оказывают влияние идентифицированные Т. Мальтусом естественные и превентивные меры. Этот слабый вариант приводит в пределе к возвращению заработной платы на уровень прожиточного минимума только в том случае, когда демографический отклик является достаточно сильным, и только в отсутствие дальнейших возмущений в системе.

Очевидно, что сильный вариант (стагнирующая на уровне прожиточного минимума заработная плата) не способен «заручиться» значительной эмпирической поддержкой. Такие переменные запасов, как численность населения, относятся к числу медленно изменяющихся. Сдвиги графиков смертности (возможно, в результате урбанизации) могли бы привести к возникновению нового равновесия, но наши возможности наблюдать за ними будут зависеть от относительных величин краткосрочных и продолжительных изменений. Для Англии показатели реальной заработной платы, исчисленные Кларком [Clark 2005: 1311], пришли на смену показателям, рассчитывавшимся Г. Фелпсом-Брауном и Ш. Хопкинс на основе широкой совокупности однородных товаров и всеобъемлющего набора номинальных заработных плат. И расчёты Кларка, и расчёты Фелпса-Брауна демонстрируют резкое снижение заработной платы в Англии при Тюдорах, в 1495-1575 гг., вызывающее немалое удивление. Оно выглядит загадочно, поскольку численность населения сначала оставалась стабильной, а затем начала расти, при этом показатели ожидаемой продолжительности жизни были необычно высокими. Выполненные Алленом [Allen 2001] и другими исследователями расчёты показывают, что в долгосрочном периоде в Европе заработная плата находилась на расходящихся траекториях. На европейском Северо-Западе рыночная цена труда возрастала, во многих случаях одновременно с ростом численности населения. Если бы и Север, и Юг Европы были подвержены воздействию мальтузианских сил ${ }^{10}$, это противоречило бы сильному варианту модели. Более того, в некоторых дебатах относительно исхода мальтузианских процессов реальная зарплата смешивается с реальным уровнем среднедушевого ВВП или доходом, что создаёт проблему, поскольку уровень занятости и количество отработанных часов могут трансформироваться, приводя и к значительным изменениям душевого или семейного дохода даже при более или менее постоянной величине заработной платы. Конечно, повышение уровня занятости могло бы, при прочих равных условиях, привести и к тому, что реальная заработная плата и реальный среднедушевой доход будут двигаться в противоположных направлениях. Одним из примеров является рост кустарной промышленности в сельской местности после 1650 г., получивший известность

9 «Согласно теории “железного закона”, зарплата колеблется вокруг физически необходимого минимума средств существования под влиянием естественного движения рабочего населения: с ростом рождаемости в рабочей среде предложение труда начинает превышать спрос на него, что ведёт к падению зарплаты вплоть до физически необходимого минимума и ниже его; уменьшение в результате этого числа рабочих приводит к сокращению предложения труда, а тем самым - к росту зарплаты» (см.: Большая советская энциклопедия. URL: http://www.bse.info-spravka.ru/). — Примеч. ред.

10 Реальная зарплата может не отражать изменения в благосостоянии, потому что некоторые предлагавшиеся в городах надбавки к зарплате всего лишь компенсировали более высокий риск смертности. К тому же мы не знаем, в какой степени варьировалась с течением времени доля натуральных платежей и действительно ли более высокие выплаты наличными деньгами компенсировали снижение выплат, выраженных в зерне, и т. д. 
как феномен протоиндустриализации. У нас есть все основания полагать, что в течение всего предшествовавшего Промышленной революции столетия происходил рост трудозатрат [Vries 1994; 2008; Voth 1998; 2001a; 2001b).

Сопоставление с предсказаниями слабой модели, в которой акцент делается на механизмах равновесия, не слишком информативно. Мы имеем возможность наблюдать поток таких переменных, как частые рождения и смерти, и соотносить их с ценами на продукты питания и реальные заработные платы. На коротких отрезках времени до 1750 г. движение в численности населения в некоторой степени подтверждает мальтузианский отклик ${ }^{11}$. Показатели смертности и брачности способны изменяться даже в краткосрочном периоде. Частые голод, войны и эпидемии имели далеко не столь значительные долгосрочные последствия, как об этом нередко думают, и обычно вслед за резким снижением численности населения следовал рост заработной платы. В течение нескольких лет непривычно высокая рождаемость и низкая смертность компенсировали первоначальное снижение численности населения [Watkins, Menken 1985; Watkins, Walle 1985]. В оригинальной работе Р. Ли, основывавшейся на использовании данных Ригли-Шофилда о численности населения, демонстрируется быстрое изменение брачности (слабое и с лагом во времени, что снижает достоверность) в ответ на вариации заработной платы, в то время как ожидаемая продолжительность жизни остаётся в значительной степени независимой от этой динамики.

При проверке как сильного, так и слабого варианта мальтузианской модели основную проблему представляет эндогенность. Заработная плата оказывает влияние на численность населения, и наоборот [Lee, Anderson 2002]. Одно из потенциально возможных направлений продвижения вперёд - использование экзогенного источника идентификации. М. Келли в недавней работе высказывает предположение, что одним из полезных инструментов исследования вопросов, связанных с заработной платой, является погода, и обусловленную ею часть вариаций заработной платы никак нельзя объяснить обратной зависимостью от численности населения [Kelly 2005]. Соответствующие исчисления позволяют сделать вывод о наличии сильных доказательств действия мальтузианских ограничений в Англии до 1650 г., когда изменения в заработной плате вызывали сильную (и положительную) реакцию нормы брачности и сильный (и отрицательный) отклик нормы смертности. Полученные Келли результаты позволяют предположить, что происходившие флуктуации реальной заработной платы оказывали большее воздействие на брачность, чем на смертность. Следовательно, в краткосрочном периоде предупредительные меры были сильнее, чем реальные препятствия, но и те и другие играли важные роли.

Альтернативным методом являются векторные авторегрессии. Э. Николини [Nicolini 2007], а также Крафтс и Миллс [Crafts, Mills 2009] используют их в целях моделирования динамической обратной связи между рождаемостью, смертностью и реальной заработной платой в Англии. С её помощью исследователи изучали силу предупредительных мер и реальных препятствий. Авторы обеих работ пришли к выводу о наличии более сильных доказательств в пользу мальтузианской системы сдержек и противовесов балансов в период до середины XVII века, чем для последующих десятилетий. Особенно действенным является канал связи с рождаемостью, в то время как канал связи со смертностью проявил себя значительно слабее. После 1650 г. сила первого из каналов ослабевает. Николини приходит к выводу о том, что, «возможно, до Мальтуса мир был не таким уж мальтузианским» [Nicolini 2007]. Как и в случае со всеми отрицательными результатами, всегда остаётся вопрос: связаны ли они с недостатками применявшихся статистических процедур, ограниченностью идентифицируемой вариации в данных или с истинным отсутствием причинно-следственной связи? В целом использовавшаяся Келли IV-процедура представляется более перспективным способом установления причинно-следственной зависимости и силы взаимодействий.

11 Например, в работе Галора представлены графики, показывающие, что численность населения и реальные заработные платы в доиндустриальной Англии двигались в противоположных направлениях (по грубым оценкам), а между «черновыми» нормами рождаемости и смертности имела место отрицательная корреляция [Galor 2005: 183-184]. 
Таким образом, прослеживается определённый прогресс в исследованиях краткосрочных откликов. Однако вопрос о точной оценке вклада демографических факторов в расхождение показателей подушевого дохода в начале европейского Нового времени пока остаётся без удовлетворительного ответа. В Золотой век в Голландии выплачивалась исключительно высокая по сравнению с остальной Европой заработная плата, в то время как численность населения там была относительно стабильной. Мы не знаем, какие иные, помимо высоких уровней урбанизации, особенности поведения, связанного с рождаемостью, или графиков смертности (если они вообще имеют значение), определяли рассматриваемый феномен. Пример Голландии позволяет предположить, что в то время как в краткосрочном периоде могли функционировать мальтузианские механизмы приспособления, многие интересные изменения были вызваны другими факторами. Начиная с позднего Средневековья по всей Европе было множество регионов и городов, жители которых получали доходы, превышавшие традиционно определявшийся прожиточный минимум, в отсутствие сопутствующего роста численности населения. Некоторые универсальные модели роста предполагают - сдержанно - повышение подушевых доходов накануне Промышленной революции [Jones 2001; Galor 2005]. В целом эта гипотеза подтверждается: в некоторых частях Европы уровень жизни постепенно повышался вплоть до начала XIX века. Предлагаемое обоснование - отложенный во времени отклик на технологические достижения - представляется не слишком убедительным: и до наступления Нового времени во многих человеческих популяциях (особенно в европейских) совокупные нормы рождаемости были значительно ниже, чем их биологический максимум. После каждого периода голода нормы рождаемости значительно возрастали. Это позволяет допустить, что они могли увеличиться и в ответ на повышение уровня жизни. Однако возникает один очень важный вопрос: почему европейцы ограничивали рождаемость, причём довольно необычным способом, когда некоторые женщины вступали в отсроченные браки, а другие были обречены на безбрачие? Какие социальные институты ответственны за «европейскую брачную матрицу»? В соответствии с одной из интересных гипотез, возникновение ограничений на рождаемость связывается с высокой ценой труда после окончания пандемии бубонной чумы («Чёрной смерти») [Zanden, Moor 2010], что обусловило повышение ценности женщин как работниц. Тем самым их длительное пребывание в составе рабочей силы было весьма выгодным, что заставляло женщин переносить материнство на более поздний срок. Однако почему этот механизм работал в Нидерландах, но не работал, например, в Италии, Китае или Индии? Тем более что во всех этих странах имели место вспышки эпидемии чумы.

Один из способов установления связи высокой заработной платы со специфическими для Европы особенностями требует рассмотрения графиков городской смертности. Европейские города были поистине смертельными ловушками (показатели смертности в них были гораздо выше, чем в сельской местности). Напротив, в Китае и Японии показатели городской и сельской смертности не слишком отличались друг от друга [Woods 2003]. Важную роль в данном контексте могли играть различные культурные практики, такие как регулярный вывоз экскрементов в городах Дальнего Востока и использование их в качестве удобрений в сельской местности. Европейские города были гораздо более нездоровыми местами, не обеспечивали нормальных условий для жизни (в силу перенаселённости и плохих санитарных условий), сильнее страдали от эпидемий инфекционных болезней и военных действий, в частности осад и грабежей со стороны противника. Следовательно, линия $D D$ на нашем графике, отображающая сельское и городское демографическое поведение, в силу эффекта сложения могла бы переместиться выше в некотором пространстве $W-D$. Тем самым возникает множественное равновесие: общества могли переходить от одного состояния (многочисленное население, низкая заработная плата, маленькие города и низкая агрегированная норма смертности) к другому, характеризующемуся меньшей численностью населения, но более высокой заработной платой, более крупными городами и высокой смертностью. Переход экономики от одного равновесного состояния к другому мог инициироваться сильными шоковыми воздействиями, такими как пандемия «Чёрной смерти». 
Впрочем, значение европейских городов определялось не только очень высокими показателями смертности. Города были местами, в которых велась международная торговля, где создавались институты частной собственности, поддерживавшие функционирование рынков товаров, капитала и труда, и одновременно - центрами изобретательской деятельности. Сама городская жизнедеятельность способствовала повышению вероятности создания новых технических приёмов, имевших большое экономическое значение: возможно, что усовершенствование технологий самих по себе было результатом урбанизации [Clark, Hamilton 2006; Voigtländer, Voth 2006]. Правомерно допустить, что рост городов шёл рука об руку с медленным, постепенным сдвигом технологического графика, что способствовало приведению в соответствие более высокой заработной платы и более высокой численности населения. Это означает, что чем большим будет городской сектор при любом уровне численности населения, тем выше будет и доход. Таким образом, мы ещё немного приблизились к объяснению голландской «аномалии». Урбанизация является отнюдь не только индикатором производительности. Она способна сыграть роль движущей силы, стимулирующей рост производительности в расчёте на душу населения. В этом случае в краткосрочном периоде продолжают доминировать мальтузианские силы, но ключевое объясняемое уже никак не следует из базисных принципов Мальтуса.

В какой-то момент в большинстве европейских стран произошло ускорение роста численности населения, имевшее очень важное значение. Довольно часто рост рождаемости и (или) снижение смертности становится сигналом об окончании предшествовавшего режима. В конечном счёте следовавшие за понижательной тенденцией смертности нормы рождаемости привели к завершению «демографического перехода» ${ }^{12}$. Последняя «сверка» оценок населения Англии Ригли-Шофилда [Wrigley et al. 1997] показывает, что увеличение рождаемости было доминирующей причиной более быстрого роста; определённую роль сыграла и смертность, но её вклад в ускорение не превышал одной трети ${ }^{13}$. Представляется, что к 1750 г. прежний демографический режим окончательно сошёл со сцены. Патрик Галловей обнаруживает, что в середине XVIII века в Англии в краткосрочном периоде показатели естественного движения населения уже не реагировали на изменения цен [Galloway 1988].

Хотя взрывной рост численности населения в Европе после 1800 г. был во многом связан с повышением рождаемости, в конечном счёте снижение смертности сыграло более важную роль. Рождаемость следовала понижательной тенденции, во многих случаях с задержками, измерявшимися десятилетиями [Coale, Watkins 1986; Lee 2003]. Основное снижение рождаемости происходило в течение нескольких десятков лет. Оно началось в 1870 г. и ускорилось после 1890 г. В ряде стран (Великобритания, Германия, Швеция, Нидерланды, Финляндия, Бельгия) показатели рождаемости носили устойчивый характер, и в некоторых случаях спаду рождаемости предшествовало некоторое её увеличение. Например, в Нидерландах в 1850-1880 гг. среднее количество детей в расчёте на одну женщину увеличилось с 4,5 до 5,5. Но к 1890 г. показатель рождаемости вернулся к предшествовавшему уровню. В большинстве европейских стран первые значительные сокращения рождаемости произошли после 1880-х гг., гораздо позднее начала охватившей континент индустриализации. В некоторых странах снижение рождаемости последовало после существенного сокращения младенческой смертности (Швеция, Бельгия, Дания); в других странах происходило одновременное снижение обоих показателей (Франция, Германия, Нидерланды) [Chesnais 1992].

12 Интересный обзор представлен в работе: [Chesnais 1992]. Предложенная концепция возвращает нас к опубликованной в 1920-х гг. работе Уоррена Томпсона.

13 Э. Ригли показывал, что в отсутствие в XVIII веке снижения смертности рост ускорился бы на $1,25 \%$, а в отсутствие изменений в рождаемости - на $0,5 \%$ [Wrigley 1983]. Это означает, что ускорение более чем на $70 \%$ было обусловлено изменениями в рождаемости. В другой работе, выполненной в соавторстве, Ригли уточняет прежние выводы: снижение смертности происходило более высокими темпами, однако соотношение факторов, скорее всего, изменилось не слишком значительно [Wrigley et al. 1997]. 
Установление экономических причин снижения рождаемости представляет собой не самую простую задачу. Пока специалисты так и не пришли к согласию относительно важнейших определивших это явление факторов [Alter 1992]. Правильную интерпретацию затрудняют как временные вариации этого показателя, так и различия между европейскими странами. Участники крупнейшего сравнительного исследования по изучению европейской рождаемости (European Fertility Project, EFP), осуществлённого под эгидой Принстонского университета, пришли к выводу об отсутствии чётко выраженных связей между социально-экономическими факторами и изменениями показателей рождаемости. Вместо этого доминирующие роли в данном случае играли этнические, религиозные, лингвистические и культурные факторы [Coale, Watkins 1986]. Аналогичный вывод относительно Англии сделал Р. Вудс, приписывающий викторианское снижение рождаемости изменениям в сфере идеологии и прежде всего, «возникшим в начале 1860-х гг. желанию или готовности к ограничению размера семьи» [Woods 2000: 150]. Исследователь высказывает довольно провокационное предположение, согласно которому «для большинства викторианцев внове был сам вопрос о том, “сколько детей они хотели бы иметь” " [Woods 2000: 169]. Изменения в рождаемости объясняет модель диффузии, согласно которой знания о технике предохранения распространялись изустно. Основная причина, почему учёные приняли научные результаты EFP, заключается в примечательном совпадении во времени демографического перехода и его распространения посредством неформальных разговоров ${ }^{14}$.

Исследователи, рассматривающие не только широкие агрегированные показатели, но и региональные данные, нередко приходят к иным, чем большинство специалистов, заключениям. Например, в Баварии важную роль сыграли альтернативные издержки, связанные с имевшимся у женщин временем, а также религия и политические предпочтения [Brown, Guinnane 2002]. Более того, возможно, что статистические данные, на которых основывались выводы участников EFP, являются менее надёжными, чем ранее считалось. Произошедший до 1914 г. по всей Европе одновременный спад показателей воспроизводства означает, что, объясняя снижение рождаемости, мы должны принимать во внимание не только экономику. Вероятно, столь существенное падение европейской рождаемости было обусловлено доминирующей ролью экзогенных, неэкономических факторов. Впрочем, данное обстоятельство представляет собой дополнительную трудность отнюдь не для всех моделей. Однако для наиболее амбициозного класса структурных моделей, разработанных в традиции универсальных моделей роста, очевидная невозможность объяснить изменение рождаемости действием экономических факторов представляет проблему.

Во многих моделях долгосрочного роста переход в показателях рождаемости играет решающую роль, а временная динамика её снижения занимает центральное место во многих теориях перехода к самоподдерживающемуся росту. Обычно спад моделируется как реакция на изменяющиеся экономические стимулы. В наиболее известных интерпретациях, предложенных Г. Беккером и Р. Барро [Becker, Barro 1988], а также Р. Лукасом [Lucas 2002], основное внимание уделяется количественнокачественному выбору, перед которым оказываются родители в контексте более быстрых технологических изменений и более высокой отдачи на человеческий капитал. Набор стандартных аргументов включает следующее: (а) повышение премии за квалификацию, зачастую обусловленное изменениями в технологии; (b) ограничиваемая родителями рождаемость как реакция на изменение в выборе между количеством и качеством детей. Впрочем, и в этом случае существуют определённые проблемы. Вероятнее всего что до 1870 г. традиционно измеряемая отдача на человеческий капитал если и увеличилась, то незначительно. Авторы моделей, основывающихся на привязке динамики населения к технологическому прогрессу самому по себе (таких, как модель Галора и Вейла [Galor, Weil 2000]), в случае их применения к Англии сталкиваются с временны́ми проблемами, так как произошедшее здесь в середине XVIII века ускорение демографического роста предшествовало сколько-нибудь серьёзному

14 Дж. Клеланд и К. Уилсон убеждены, что одновременный быстрый переход европейских стран ставит под сомнение возможность обнаружения любой достаточно мощной экономической силы, которая могла бы рассматриваться как разумное его объяснение [Cleland, Wilson 1987]. 
воздействию технологических изменений на объём выпуска в расчёте на душу населения. Более того, поскольку с точки зрения занятости рабочего класса экономические выгоды формального образования были, по всей вероятности, минимальными, любая модель родительского выбора относительно рождаемости, основывающаяся на решении проблемы количества-качества, в лучшем случае объясняет демографическое поведение относительно небольшой группы населения.

Ответы на вопрос о количественно-качественном выборе не подкрепляются достоверными фактическими свидетельствами. Более вероятным представляется довод, согласно которому во второй половине XIX столетия произошло увеличение чистых затрат, связанных с количеством детей в семье. В альтернативной интерпретации основное внимание уделяется важности государственного вмешательства, выразившегося в принятии законов об обязательном школьном образовании и регулировании детского труда. М. Депке приводит аргументы, согласно которым последнее имело решающее значение, и обосновывает положение, что другие меры в рамках политики государства не могли оказать столь же сильного влияния на рождаемость (например, предоставление субсидий на образование) [Doepke 2004]. Если мы соглашаемся с положением о важности государственного вмешательства, то решающее значение приобретает изучение экономического и других факторов, обусловивших принятие законов о детском труде или о реформах в сфере образования [Doepke, Zilibotti 2005]. Галор и Моав подчёркивают важное значение закона Бальфура (Balfour's Act) ${ }^{15}$, в соответствии с которым в Англии было введено обязательное школьное образование [Galor, Moav 2006]. По мнению исследователей, решающее значение для успеха реформы имела её поддержка со стороны капиталистов, нуждавшихся в более квалифицированной рабочей силе ${ }^{16}$.

У нас нет оснований для решительного заявления о том, что вмешательство государства сыграло решающую роль в том, что английские дети оставили фабричные цеха и заполнили школьные классы. В США государственные законы о школьном образовании оказали незначительное влияние на детский труд [Moehling 1999]. В то же время проблемы, связанные с достоверностью данных, ведут к смещению оценок эффективности этих мер и сводят на нет все усилия. В Великобритании, как считают К. Нардинелли и П. Кирби, принятие законов о детском труде происходило одновременно с технологическими изменениями, которые привели к значительному снижению полезности детской занятости [Nardinelli 1980; Kirby 1999]. Таким образом, налицо противоречие между воззрениями экономистовтеоретиков, уделяющих основное внимание технологическим изменениям, обусловившим повышение квалификации работников, или последствиям государственного вмешательства, и оценками экономических историков, в основном отвергающих первое положение, в то время как фактические свидетельства в пользу второго рассматриваются как ограниченные.

Некоторые ограничения, связанные с имеющимися данными, представляются нам едва ли преодолимыми. Мы испытываем очевидный недостаток информации о факторах, определявших нормы рождаемости, инвестиции в образование, возраст вступления в брак и т. п. в промышленных городах Европы. Никто не проводил исследований фертильного поведения в различных возрастных когортах на микроуровне, которые могли бы однозначно идентифицировать воздействие прерывистых изменений в законах о школьном образовании и т. п. Знаменитая книга «Population History of England...» («История населения Англии...») $)^{17}$ Ригли и Шофилда основывалась на попытке воссоздания истории британских семей, а фокус внимания её авторов был сосредоточен на сельских приходах. Использовавшиеся

15 Артур Джеймс Бальфур (Arthur James Balfour; 1848-1930) — британский государственный деятель; в 1902-1905 гг. премьер-министр Великобритании. Речь идёт о законе об образовании 1902 г. (Education Act 1902), по которому в стране была создана система бесплатных школ грамоты (grammar schools). — Примеч. ред.

16 Тем самым неудачные попытки повышения квалификационной премии (более подробно см. ниже) могут объясняться этим резким сдвигом предложения.

17 См.: Wrigley E. A., Schofield R. S. 1981. The Population History of England 1541-1871. A Reconstruction. London: Edward Arbold Ltd. - Примеч. ред. 
ими данные были ограничены 1837 г. Повсюду в Европе реконструкция истории отдельных семей в XIX веке сложнее, чем в предыдущие периоды из-за усилившейся мобильности населения. Будущие исследования должны быть направлены на углубление понимания фертильного поведения и релевантных издержек воспитания детей. Более подробный анализ фертильного выбора рабочего класса, дополненный информацией о показателях посещаемости школы, экономике обучения и т. п. до и после принятия законов об обязательном школьном образовании, будет способствовать углублению понимания демографического перехода.

\section{Институты, хорошие и плохие}

В центре внимания немалой части современных дебатов, посвящённых экономическому росту, находится вопрос об относительной важности институтов в сравнении с человеческим капиталом [Glaeser et al. 2004; Rodrik, Subramanian, Trebbi 2004; Acemoglu, Johnson 2005]. Согласно результатам межстранового кросс-секционного анализа, в конце XX века ограничения на исполнительную власть демонстрируют тенденцию к положительной корреляции с более высоким объёмом выпуска в расчёте на душу населения. С учётом потенциальной возможности обратной причинности - более высокий подушевой доход способствует повышению институционального качества — работа с современными данными принципиально сосредоточена на поиске экзогенного фактора, воздействующего на институты, но не на экономические результаты (следовательно, он мог бы использоваться для координации их деятельности). Один из таких факторов, который с успехом используется, - это смертность европейских колонистов. В серии прорывных публикаций Д. Асемоглу, С. Джонсон и Дж. Робинсон показывают, что страны, благоприятные для жизни переселенцев из Европы, со временем приходили к более желательным институциональным соглашениям (см., например: [Acemoglu, Johnson, Robinson 2001]). По уровню богатства сегодня такие страны заметно превосходят другие государства. Следовательно, повышается вероятность того, что связь между институтами и эффективностью действительно является причинно-следственной.

В какой степени институциональные интерпретации способны помочь нам в достижении понимания происходившего в Европе до 1870 г. роста? Какую роль играют институциональные изменения в переходе к самоподдерживающемуся росту? Если мы анализируем институты в определённых исторических обстоятельствах, то не имеем права довольствоваться ролью государства и ограничений, налагаемых на исполнительную власть. В то же время мы не располагаем информацией, достаточной для вынесения суждения о функционировании европейских институтов в 1500-1870 гг. и их совокупном вкладе в экономический рост. Более всего мы нуждаемся в расширении круга знаний о юридических процессах, о роли «строительства государства» и о реальной значимости неформальных институциональных соглашений.

Возможно, единственное самое известное заявление в традициях институционализма было сформулировано Д. Нортом и Б. Вайнгастом [North, Weingast 1989]. Исследователи пришли к выводу, что роль Славной революции (Glorious Revolution, 1688-1689) и Билля о правах (1689) не ограничивалась подведением твёрдой основы под государственные финансы Англии. Повышение роли парламента и расширение влияния судов общего права означали сокращение властных полномочий английского монарха. Принято считать, что решающую роль в этом сыграли так называемые достоверные обязательства, то есть обязательства, которым доверяют. Тем самым был положен конец бесцеремонным, своевольным разрывам контрактов и захватам чужой собственности ${ }^{18}$. Норт и Вайнгаст обосновывают положение, согласно которому твёрдое установление прав собственности и ограничений на исполни-

18 В прошлом такая возможность существовала как в рамках правовой системы (например, при обращении в «Звёздную палату», то есть тайный Верховный суд, рассматривавший дела о наиболее тяжких преступлениях), так и с помощью грубой силы (использовавшейся, например, при захвате лондонского Тауэра и присвоении принадлежавших мастерамювелирам запасов золота и других благородных металлов). 
тельную власть обусловливает снижение премии за риск. В результате происходит ускорение процесса накопления капитала и повышается прибыльность инвестирования в новые идеи. В конечном счёте это и привело к «взлёту» темпов роста Англии.

Схожим образом большинство институциональных интерпретаций начального периода Нового времени сосредоточены на избавлении от капризного деспотического режима правления. Б. Де Лонг и А. Шлейфер возвращаются к знаменитому аргументу Ш.-Л. Монтескьё о более высоких темпах роста в республиканских государствах, в меньшей степени страдающих от произвольных вмешательств властей [DeLong, Shleifer 1993 $]^{19}$. Авторы убеждены, что пагубность абсолютистского правления определяется тремя причинами: государства, которыми управляют амбициозные властные государи, участвуют в большем количестве войн; их население вынуждено нести более тяжёлое налоговое бремя, а права собственности не пользуются должным уважением со стороны власти. К тому же так уж случилось, что самодержавные государства находились в среднем дальше от новых торговых маршрутов в Америку и Азию. Заметим, что лишь одна из перечисленных выше причин непосредственно ассоциируется с институциональной интерпретацией в её узком определении, а Де Лонгу со Шлейфером не удалось убедительно обосновать их важность.

В более поздней работе Д. Асемоглу, Д. Кантони, С. Джонсон и Дж. Робинсон попытались продемонстрировать, что особым образом взаимодействующие причины, установленные Де Лонгом и Шлейфером, способствуют усилению институтов [Acemoglu et al. 2008]. В странах, перед которыми открылись возможности атлантической торговли, происходило постепенное укрепление буржуазных общественных сил. Таким образом, в соответствии с расчётами исследователей в Англии и Соединённых провинциях Нидерландов усиливались «налагаемые на исполнительную власть ограничения». Асемоглу и его коллеги демонстрируют, что это повышение качества институтов имело значение с точки зрения роста: нормы урбанизации увеличились везде, где была географически обусловленная высокая «предрасположенность» к атлантической торговле.

Институциональные интерпретации Промышленной революции и её последствий означали возрастание роли политической экономии. Рассматривая сложившуюся в Англии в XIX веке ситуацию, Асемоглу и его соавторы обосновывают положение, согласно которому политическая власть имеет значение во многом потому, что она способна осуществлять перераспределение дохода [Acemoglu, Johnson, Robinson 2005; Acemoglu, Robinson 2006]. Учёные различают власть de јиге, то есть имеющую формальное право принимать законы и заключать соглашения, и власть de facto, то есть имеющую материальную возможность свергнуть режим правления, если её носителю пришлась не по нраву та или иная политика. Уже к 1720 г. английский парламент сосредоточил в своих руках огромную власть de jure, возвысив себя до статуса метаинститута. Но парламентарии обязаны были учитывать, что власть de facto находилась в руках представителей среднего класса, аккумулировавших постоянно возраставшее экономическое богатство. В то же время до проведения реформ 1832 и 1867 гг. этот средний класс был в значительной степени ущемлён в гражданских правах. Асемоглу и его коллеги убеждены, что Великая французская революция стала своего рода экзогенным шоком для политических систем соседних государств [Acemoglu, Robinson 2006]. Поражения, которые потерпели в наполеоновских войнах Пруссия и Австрия, подтолкнули правителей этих государств к реформам. В других завоёванных французской армией странах старые политические институты были полностью сметены. Авторы уверены, что усовершенствование институтов в окружавших Францию странах привело к ускорению их роста в начале XIX века, что в сочетании с поднявшейся после 1850 г. волной технологических изменений позволило этим странам развиваться в правильном направлении.

19 «Так как в этих последних [республиканских] государствах собственность более ограждена, то [торговцы] отваживаются на всевозможные предприятия... Будучи уверенными в неприкосновенности того, что ими приобретено, они не опасаются пускать свои приобретения в оборот, чтобы приобрести ещё больше». 
В современной литературе, посвящённой проблемам роста, институтам уделяется очень большое внимание [Rodrik, Subramanian, Trebbi 2004; North 2005]. И всё же специалисты, интерпретирующие данные о европейском экономическом росте главным образом на основе институтов, должны будут преодолеть целый ряд трудностей. Для начала упомянем об отсутствии единого мнения о том, что представляют собой институты и каким образом этот концепт должен применяться при изучении прошлого. Норт определяет институты как комплекс правил, соответствующих процедур, а также моральных и этических норм поведения, разработанных для того, чтобы ограничить поведение отдельных людей в интересах максимизации богатства или полезности принципалов [North 1981] (курсив наш. - Aвmopbl). А. Грейф включает в это определение и другие способы поведения, способные создавать исторические закономерности [Greif 2006]. В предлагаемой этим учёным модели убеждения и идеология действуют как глубинные параметры, определяющие степень эффективности, с которой общества устанавливают правила, открывающие возможность обмена и инвестирования. Конечно, существует несколько теорий, позволяющих подробно объяснить процесс изменения институтов, а также причины того, что некоторые экономики демонстрируют «более лучшие» результаты, чем другие. Все рассматриваемые в научной литературе стандартные показатели, такие как риск (воспринимаемый) экспроприации, эффективность правительства и ограничения на исполнительную власть, позволяют отобразить выбор, который делает то или иное государство, и могут быть быстро изменены. Однако это весьма проблематично для любой модели, основывающейся на допущении, согласно которому лучшие институты способны «творить чудеса» с точки зрения накопления капитала или технологического прогресса. Э. Глейзер и его коллеги показывают, что во многих случаях одни-единственные выборы приводят к изменению всех трёх стандартных показателей качества институтов [Glaeser et al. 2004]. По-видимому, в том случае, если единственной защитой прав собственности является прихоть правителя, их значение резко снижается. Волатильность, демонстрируемая этими показателями во времени, обусловливает меньшую вероятность того, что с их помощью будут идентифицированы те или иные структурные параметры политической системы. Другие, в большей степени очевидные переменные, такие как независимая судебная система, пропорциональное представительство и конституционный контроль, варьируются в значительно меньшей степени и, скорее всего, способны служить заменителями тех структурных ограничений на деятельность правительства, которые имел в виду Норт. Тем не менее, если мы имеем дело с современными данными, эти переменные оказывают довольно слабое, несущественное воздействие. Для того чтобы окончательно ответить на вопрос, необходимо обратиться к такому глубинному параметру, как политическое устройство государства, где изменение параметра происходит относительно медленно и не является простым отражением текущих экономических и политических условий.

Для 1500-1800 гг. переменная «ограничения на исполнительную власть», как следует из исследований, проведённых Асемоглу и его коллегами, позволяет успешно предсказать нормы урбанизации. То же можно сказать и об индикаторе абсолютизма Де Лонга и Шлейфера. Тем не менее, если речь идёт о начальном периоде Нового времени, применение обоих концептов связано с трудностями. Проблемы с данными, столь характерные для многих европейских государств, если речь идёт о периоде до 1800 г., и необходимость кодирования переменных, основывающихся на комплексных институциональных соглашениях, могут быть восприняты не самыми отважными исследователями как непреодолимые препятствия. В Испании времён Габсбургов, кодируемой Асемоглу и его коллегами как совершенно абсолютистское государство, короли нередко не могли добиться согласия кастильских кортесов на уплату налогов или получить иные уступки. В других королевствах при Габсбургах, в частности, в Арагоне, власть монарха ограничивалась разнообразными средневековыми «свободами» и ассамблеями. Весьма принципиальные вопросы задаются даже в отношении живого воплощения абсолютистского правления - Людовика XIV (Асемоглу и его коллеги кодируют этот режим как «1», то есть ничем не ограниченный). Большинство историков отвергли идею о том, что правление «короля-солнце» можно считать реализацией успешной, перспективной абсолютистской повестки дня. Целое поколение исследователей следует новому консенсусу, вдохновляемому inter alia работами Ролана Мунье [Mousnier 1970]. 
Эти исследователи утверждают, что, даже будучи на вершине абсолютистской пирамиды, французские короли большую часть времени должны были править страной, ища социальный компромисс и консенсус, поддерживая стабильность традиционного общества и влияние старых элит. Мы не уверены, что используемые в настоящее время классификации включают достаточное количество данных, peлевантных аргументу, согласно которому до начала XIX века причиной экономического роста были институты и ограничения на исполнительную власть ${ }^{20}$.

Безусловно, свобода действий правителей ограничивалась и в государствах, в которых функционировали комплексные системы сдержек и противовесов (Венецианская Республика, Священная Римская империя, Польша). Однако государства отнюдь не принадлежат к числу «парников», в которых пробивались бы ростки экономической динамики. Возможно, это было связано с тем, что до наступления Нового времени и образования государств с чётко определёнными стабильными границами, налагаемые на правителей рамки не играли ни однозначно положительной, ни бесспорно отрицательной экономической роли. С. Эпштейн подчёркивал преимущества мощного государства, способного обуздать погоню за рентой на местах и решать проблемы координации [Epstein 2000]. Большая часть «ограничений на исполнительную власть» принимала форму заинтересованных в получении ренты групп, стремившихся обеспечить себе постоянную долю в общем «пироге». Неудивительно, что огромные части европейской истории раннего Нового времени читаются как одна затянувшаяся повесть о ведущем в тупик пути, когда перераспределение продукции то и дело вызывает пререкания преследующих самые разные интересы групп - от местных феодалов и купеческих лобби до Церкви и цеховых корпораций ремесленников. Один из наиболее показательных примеров неэффективности французского сельскохозяйственного производства приводится в работе Ж.-Л. Розенталя [Rosenthal 1992]. Ни одна из групп, сопротивлявшихся централизации власти правителей во Франции, в Испании, России, Швеции или где бы то ни было ещё, не была заинтересована в росте. Если же им случалось одерживать верх, то ни о каком переходе к здравой долгосрочной политике не было и речи. Чаще всего дело ограничивалось заменой произвольного налогообложения (в прошлом назначавшегося правителем) произвольным же взысканием платежей местными монополиями ${ }^{21}$.

В начале Нового времени многие государства, в которых функционировали хорошие с современной точки зрения институты, не относились к числу сильных. Присущая международной политике жестокость подрывала жизнеспособность искусного государственного руководства. Участие в войне Камбрейской лиги (1508-1516) привело к ослаблению венецианской мощи и обусловило окончание периода экономического процветания. Современные ограничения, накладываемые на исполнительную власть, идут рука об руку с существенно более низкой вероятностью военных конфликтов между демократиями (которые к тому же чаще выигрывают в вооружённых столкновениях с недемократическими странами). В начале Нового времени эта корреляция, вероятно, имела обратный знак. Политические образования с эффективно ограниченной исполнительной властью, чьи правители действовали без оглядки на внутренних оппонентов, быстро становились жертвами внешних врагов. Таким образом, в раннем Новом времени менее развитые, но крупные и обладавшие сильными армиями политические единицы, такие как молодые национальные государства, во главе которых стояли Филипп II, Густав II Адольф и Людовик XIV, непосредственно угрожали более богатым, но небольшим городам-государствам в Италии, Германии, а также Нижним землям (Исторические Нидерланды). Экономически успешные, но компактные государственные образования часто становились добычей для превосходящих военных

20 Сp. с недавней критикой ревизионистских доводов в работе: [Beik 2005].

21 Показательным в рассматриваемом контексте является пример Венеции. С точки зрения институционального устройства это была едва ли не самая близкая к современному идеалу политическая конструкция. Права собственности были хорошо защищены. Политическая и судебная власть контролировалась высшей буржуазией. Теоретически глава государства (дож) избирался пожизненно, но в действительности всё зависело от результатов его правления. Уже в XV веке в республике функционировала патентная система. Однако, несмотря на рано полученное богатство и успех в качестве одной из морских держав, впоследствии Венеции пришлось пережить военный и экономический спады. 
сил или вынуждены были нести очень высокие и несоразмерные имевшейся налоговой базе военные расходы $^{22}$. Этой незавидной судьбы избежали лишь две европейские области, обладавшие редкими географическими преимуществами, препятствовавшими вторжениям иностранных армий, — Англия и северные Нидерланды. Но даже эти экономики вынуждены были нести бремя высоких налогов: издержки выживания в меркантилистском мире основывались на идее о том, что экономическая игра между государствами является антагонистической (с нулевой суммой), а торговля с зарубежными странами служит политическим и династическим интересам.

Возникает ситуация фундаментального выбора: мощное центральное правительство было более эффективным с точки зрения защиты экономики от иностранных мародёров, но в то же самое время оно оставалось практически безучастным к системе внутренних сдержек и противовесов. Если мы возьмём крайний польский случай, то строгие ограничения на исполнительную власть отнюдь не способствовали экономическому развитию, не в последнюю очередь потому, что они могли внести определённый вклад в исчезновение самого государства вследствие череды ужасных военных поражений. Наиболее важной институциональной чертой общества было не столько сильное или слабое правительство, сколько способность к быстрой институциональной перестройке, к адаптации институтов в соответствии с меняющимися обстоятельствами, с минимальными противоречиями и потерями.

Пришёл черёд поделиться двумя нашими наблюдениями относительно значения институтов в трансформации Европы после 1750 г. Во-первых, на западе континента поднимается волна протеста, направленная на ориентированные на поиск собственной выгоды институты, ассоциировавшиеся с меркантилистским старым порядком (ancien régime) [Mokyr 2006]. Это движение основывалось отчасти на изменяющейся политической роли экономических элит, отчасти на усиливающемся влиянии более либеральной идеологии. Во-вторых, во многих случаях условием осуществления изменений становилось применение силы (например, в США и во Франции). Важным исключением является Англия, где существование такого метаинститута, как парламент, открыло возможность адаптации к изменявшимся убеждениям и обстоятельствам, а также дало шанс осуществления реформы системы без скольконибудь значительных беспорядков [Mokyr, Nye 2007]. Но даже в этом случае последовавшее после Славной революции переустройство было бы невозможно без предшествовавшего ему кровопролития во время Гражданской войны 1642-1660 гг.

В научной литературе, посвящённой развитию европейских институтов в 1500-1870 гг., рассматриваются главным образом государственные и формальные институты. Неправительственным институтам (как формальным, так и неформальным) уделяется гораздо меньше внимания (хотя и не всегда; см.: [Mokyr 2008]). Такой подход вызывает немалое удивление, так как в работах, посвящённых Средневековью, неправительственные соглашения признаются наиболее важными [Greif 2006]. Если, как это доказывается в фундаментальной институциональной литературе, уважение к правам собственности и обращение за помощью к правовому процессу являются ключевыми с точки зрения экономического развития, нам необходимо предложить переменные, позволяющие более полно «ухватить» эти параметры $^{23}$. Для того чтобы количественно оценить эффективные правовые или основывающиеся на традициях ограничения на действия исполнительной власти или местных властных групп - нечто затрудняющее признание правоты без обращения к закону, - необходим более сложный и исторически интерпретируемый набор индикаторов. Помимо прочего, оппортунистическое поведение, ведущее к равновесию по Парето, может быть преодолено совокупностью механизмов (помимо стандартного принуждения со стороны третьей силы), обеспечивающих членам избранных групп возможность под-

22 Современные данные свидетельствуют об устойчивой отрицательной корреляции между военными конфликтами и политической нестабильностью, с одной стороны, и ростом — с другой [Alesina et al. 1996].

23 Асемоглу и Джонсон утверждают, что институциональная защита собственности имеет решающее значение, в то время как заключающие контракты институты оказывают влияние лишь на тип финансового посредничества, участниками которого они являются [Acemoglu, Johnson 2005]. 
твердить свою кредитоспособность рядом связанных с высокими затратами сигналов [Greif 2006], и в состоянии сыграть в кооперативном стиле. Современная институциональная научная литература показала, что такого рода договорённости могут сохранять значительную часть своей объясняющей силы до наших дней [Ellickson 1991; Posner 2000]. Исследователям необходимо изучить периоды времени, не охваченные Грейфом, а также оценить значение договорённостей относительно уже рассматривавшихся формальных институтов, таких как парламент.

Показательный пример представляет собой Англия XVIII века. В одной из наших работ утверждается, что неформальные соглашения и культурные изменения оказывали на функционирование рынка воздействие, сходное с влиянием государственных институтов [Mokyr 2008]. Возникающее в больших группах людей устойчивое равновесие позволяет сигнализировать о кредитоспособности. Представители среднего класса перенимали черты, обычно ассоциировавшиеся с поведением джентльменов, а поскольку, как предполагалось, джентльменам не свойственна жадность, возникали основания для ожиданий кооперации в одноразовых играх типа «дилеммы заключённого» [Clark 2000]. Более того, в XVIII столетии в Англии происходил быстрый рост формальных и неформальных социальных сетей. К 1800 г. количество членов различных дружеских обществ, масонских лож и клубов, в которых можно было пообедать, достигло 600 тыс. человек. Следствием этого роста стало повышение эффективности репутационных механизмов и более быстрое распространение сообщений о некооперативном поведении. В результате в XVIII веке в Англии, возможно, уменьшилось количество случаев «безбилетничества» в сфере предоставления общественных благ; не были исключением в этом отношении местное администрирование, проекты, связанные с сокращением административно-хозяйственных затрат, образование и здравоохранение. Можно утверждать, что такого рода неформальные институты благоприятствовали не только функционированию рынков, но и выходу Англии на ведущие позиции в технологической сфере, так как успех этих институтов обеспечил значительное повышение эффективности системы обучения различным профессиям [Humphries 2003]. Контракты на профессиональное обучение были особенно уязвимы перед лицом оппортунистического поведения, тем более что цеховая система (в рамках которой осуществлялось это обучение) в Англии (по сравнению с другими странами) была относительно слабой. Тем не менее система профессионального обучения функционировала и в Англии. В результате страна могла рассчитывать на большое количество высококвалифицированных ремесленников и механиков, которые, возможно, сыграли решающую роль в развёртывании Промышленной революции.

Асемоглу и Робинсон подчёркивают, что после 1830 г. бесперебойное функционирование английских институтов в какой-то мере обеспечивалось соглашениями о разделении власти между аристократией и богатейшей буржуазией. Рабочие, возможно, и не обладали властью de jure, но подразумеваемая способность к бунту наделяла их властью de facto. В анализе, основывающемся на обстоятельствах реальной политики, не учитывается возраставшее влияние идеологии Просвещения на политические институты; анализ, основанный на изучении распределения власти de facto, остаётся неполным. Английская армия эффективно подавила народные бунты в 1790-х гг., а также выступления луддитов. Чартистское движение носило в основном ненасильственный характер, а несколько наиболее опасных вспышек были быстро подавлены. Вероятно, в данном случае имело место проявление значительного совпадения друг с другом власти de jure и de facto. Возможно, это обстоятельство было ключевым с точки зрения английской политической модели. Тем не менее поразительно, что носители политической власти того времени использовали её для перераспределения доходов в свою пользу (один из самых показательных примеров - изменение Хлебных законов (Corn Laws) в 1815 г.). Однако на протяжении всего XIX века стремление к получению такого рода выгод постепенно ослабевало, и к 1860 г. уровень поиска рентных возможностей достиг исторического минимума. 


\section{Человеческий капитал и культура}

Во многих моделях долгосрочного роста переход к самоподдерживающемуся его типу рассматривается едва ли не как синоним возрастающей отдачи от образования и значительного ускорения процесса подготовки квалифицированных кадров. Г. Беккер, К. Мёрфи и Р. Тамура предложили модель экономики, в которой отсутствует постоянный капитал как фактор производства [Becker, Murphy, Tamura 1990]. Развитие человеческого капитала непосредственно ведёт к увеличению объёма выпуска. Авторы исходят из того, что производство человеческого капитала основывается на родительских инвестициях в детей в форме уделяемого им времени. Родители максимизируют собственную полезность, которая выводится из уровня их потребления, количества детей в семье и их качества. Когда родители начинают массово инвестировать в образование своего потомства, темпы экономического роста повышаются. Если доходы достаточно велики, то показатели рождаемости снижаются, что обусловливает увеличение инвестиций в качество детей. Авторы этой модели рассматривают человеческий капитал и рост едва ли не как идентичные категории. Р. Лукас расширяет предложенный Беккером и его коллегами подход, добавляя к модели сферу использования земли с убывающей отдачей, а также сферу современного производства, в которую человеческий капитал входит линейно [Lucas 2002]. Аналогичного направления придерживались и авторы многих других универсальных моделей роста, добавляя взаимодействия с темпами технологических изменений.

Однако происходившие в период Промышленной революции в Англии события в значительной степени отличаются от этих предсказаний. До настоящего времени большая часть фактических свидетельств основывается на способности отдельных людей написать собственное имя, что, возможно, подтверждает данные о низком уровне грамотности [Schofield 1973]. В период Промышленной революции грамотность населения Англии была относительно низкой и, в общем, её уровень оставался стабильным. Это тем более верно, если мы примем во внимание относительно высокий уровень богатства Англии перед Промышленной революцией и повышение спроса на грамотность по мере роста доходов [Mitch 1999]. Да и в течение самой Промышленной революции способность или желание британцев дать образование подрастающему поколению не слишком изменились. До 1870-х гг. показатели регистрации новых учеников в школах оставались примерно на одном и том же уровне [Flora, Kraus, Pfenning 1983].

Во многих случаях разработанные в традициях Лукаса модели предсказывают, что в период перехода к самоподдерживающемуся росту спрос на человеческий капитал возрастает. К тому же технологические изменения должны в значительной степени зависеть от уровня квалификации. С исторической точки зрения это довольно проблематично. Мы располагаем недостаточными знаниями об изменении во времени премии за квалификацию, так как соответствующие оценки были сделаны на основе лишь нескольких профессий и не являются репрезентативными. Более того, надбавка за квалификацию представляет собой редуцированный показатель, и его изменения могут отражать любое сочетание изменяющихся факторов спроса и (или) предложения. Количество достоверных свидетельств об увеличении отдачи от образования в XVIII или XIX столетиях совсем невелико. По утверждению Дж. Уильямсона, в 1750-1850 гг. в Англии премия за квалификацию повышалась, но впоследствии начала снижаться [Williamson 1985]. Однако большинство специалистов по экономической истории не разделяют предложенную Уильямсоном интерпретацию. Как убедительно показал Ч. Фейнштейн, мы вообще не располагаем сколько-нибудь убедительными свидетельствами об изменении с течением времени надбавки за квалификацию [Feinstein 1988]24.

Весьма сомнительно, что основные события в производстве во время Промышленной революции и даже после неё зависели от увеличения человеческого капитала. Возможно, более важную роль игра-

24 См. также: [Zanden 2009]. 
ли некоторые административные задачи. Отмеченное Г. Бутом повышение заработной платы хорошо образованных работников [Boot 1999] позволяет предположить существование небольших сегментов экономики, в которых формальное образование могло приносить довольно высокую отдачу. В то же время технологические изменения сами по себе, вероятно, не зависели от квалификации работников. Более того, движение луддитов, сосредоточивших усилия на разрушении использовавшихся в производстве машин, лишний раз привлекает внимание к тому, что Первая промышленная революция сопровождалась деквалификацией рабочих ${ }^{25}$. Таким образом, перед доминирующими экономическими моделями долгосрочного развития возникает трудная проблема. В текстильной промышленности внедрение мюль-машин для прядения хлопка, прядильных станков периодического действия и прядильных машин Аркрайта позволило заместить квалифицированный труд сочетанием капитала и неквалифицированного труда. Фактические свидетельства о положении в более традиционных сферах носят в большей степени противоречивый характер. Изучению соотношения заработной платы ремесленников и рабочих в Англии в 1700-1850 гг. была посвящена работа Кларка (Clark 2007a). Согласно имеющимся у него данным, в рассматриваемом периоде премия за квалификацию снизилась с 65 до $50 \%$. Конечно, технологические изменения в строительной отрасли носили ограниченный характер. Тем не менее, если мы можем рассматривать некую сферу как показательную с точки зрения более общих экономических тенденций, у нас есть все основания говорить о происходившей в течение полутора столетий, предшествовавших 1850 г., умеренной деквалификации рабочей силы. Возможно, сосредоточение внимания на среднем уровне развития человеческого капитала в индустриальных обществах менее полезно, чем изучение изменений в его распределении. Происходившие в XIX веке технологические изменения создавали спрос на высококвалифицированных механиков и инженеров в верхнем хвосте распределения и, вероятно, обусловливали снижение потребности в квалификации среди тех, кто был занят ручным трудом. За стагнацией традиционно измеряемой надбавки за квалификацию, возможно, скрывается растущая степень поляризации рабочей силы, поскольку индустриализация ведёт к повышению отдачи навыков линейного управления и контроля, а также знаний в области механики и к сокращению оплаты стандартных умений (в кузнечном деле, плотницких работах, ткачестве).

В настоящее время у нас нет достаточных свидетельств, позволяющих судить, должны ли мы рассматривать начавшееся в XIX веке и продолжающееся в наши дни увеличение инвестиций в человеческий капитал в качестве эндогенного отклика на изменения в ценах на факторы производства и других экономических стимулах как результат повышения реальных доходов (образование детей превратилось в обычное потребительское благо) или имели место экзогенные сдвиги в предложении образования (значительно задержавшийся во времени эффект Просвещения), характерные для XIX столетия национализм и формирование национальных государств или попытки усиления общественного контроля над низшими классами ${ }^{26}$.

Если мы идентифицируем человеческий капитал исключительно с формальным образованием и разрывом с доиндустриальным периодом, произошедшим в Англии после 1750 г., у нас остаётся лишь ограниченное количество фактических свидетельств в поддержку универсальных моделей роста. Представляется, что основной вывод заключается в следующем: в то время как базирующиеся на человеческом капитале подходы показывают интересные результаты для периода после 1850 г., лишь некоторые модели роста способны сообщить нам нечто действительно ценное о первых попытках избавления от оков низкого роста. В настоящее время разработаны первые модели, позволяющие эндогенизировать,

25 Адам Фергюсон, современник Адама Смита, писал в 1767 г., что многие ремесла не требуют никаких способностей; невежество - мать не только суеверий, но и промышленности, поэтому более всего процветают те промышленники, которые менее всего обращаются к разуму. К. О’Рурком, А. Рахманом и А. Тейлором разработана современная концепция, в которой большое внимание уделяется роли деквалификации [O’Rourke, Rahman, Taylor 2008].

26 Последний эффект в духе работы Асемоглу и Робинсона, где расширение круга избирателей рассматривается как реакция на угрозы революции [Acemoglu, Robinson 2000]. Аналогичным образом может быть обосновано и введение обязательного школьного образования. 
или сделать внутренним по отношению к системе, переход от замещающих квалификацию к использующим квалификацию технологическим изменениям [O’Rourke, Rahman, Taylor 2008]. Однако в случае расширения фокуса наш вердикт претерпевает изменения. Если мы перейдём от рассмотрения частного случая Англии к европейским тенденциям в целом, подвергая анализу более длительный период (1500-1870 гг.), а также используем более общие определения человеческого капитала, включив в них такие факторы, как способность к количественному мышлению и дисциплина, равно как и неформальное образование (обучение ремеслу), то степень соответствия теории и истории заметно повышается.

Нет ни малейших сомнений в том, что в Европе некоторые формы человеческого капитала (знание основ грамоты и счета) находились на подъёме задолго до Промышленной революции. В какой-то степени этому способствовала Реформация, в какой-то - медленный рост доходов. Не следует забывать и о растущем спросе на грамотность в сфере услуг в эпоху быстрого роста коммерции и финансов. Последовательные и сопоставимые оценки показателей грамотности едва ли проясняют ситуацию, тем более что ранние источники данных (до 1800 г.) практически недоступны. В современной литературе приводятся данные о способности людей, живших на рубеже XVIII-XIX веков и позже, расписываться в документах. В Англии в это время доля мужчин, умевших написать собственное имя, составляла около $60 \%$, а женщин - 40\%, что примерно так же, как в Бельгии, чуть лучше, чем во Франции, но хуже, чем в Нидерландах и Германии [Reis 2005: 202]. Изучавшие книгопечатание в Европе в начале Нового времени Й. Батен и Я. ван Занден обнаружили, что после изобретения типографского набора произошёл настоящий взрыв выпуска продукции в расчёте на душу населения, производство увеличилось в 10-100 раз [Baten, Zanden 2008]. Нидерланды и Великобритания как самые богатые регионы, где приобреталось и самое большое количество книг, значительно опережали все остальные страны ${ }^{27}$.

Одним из дополнительных показателей развития человеческого капитала является способность к количественному мышлению. Способность правильно понимать смысл чисел и запоминать их, а также осуществлять основные их преобразования является важнейшим навыком для лиц, участвующих в различных коммерческих сделках. Измерение показателей способности к количественному мышлению в определённых исторических условиях может быть осуществлено очень простым способом. Мы высказывали предположение о возможности использования возрастного распределения в качестве индикатоpa количественного мышления [Mokyr 1985]. Во многих исторических источниках заметна тенденция к указанию возрастов кратных пяти, в то время как истинное распределение должно быть существенно более гладким. В процессе одного из исследований Б. Ахирн, Й. Батен и Д. Крайен создали комплексную базу данных, охватывающую два тысячелетия нашей истории [A’Hearn, Baten, Crayen 2009]. Учёные обнаружили фактические данные, свидетельствующие о тенденции к повышению в Европе способности населения к количественному мышлению начиная с XVI века и до настоящего времени. В то же время английский опыт говорит о стагнации уровня грамотности после 1800 г., несмотря на происходившие в экономике стремительные изменения. Чем больше будет фактических данных, полученных из областей, находящихся вне пределов Европы, и чем теснее их удастся связать с данными о различиях в доходах, определяемых более развитой способностью к количественному мышлению, тем более эффективным будет тестирование моделей, разработанных в традиции Беккера и Лукаса.

Условием дальнейшего прогресса нам видится расширение историками и экономистами концепции навыков, квалификации работников. Как правило, квалификация приобреталась отнюдь не в школе или в других формальных институтах. Скорее и главным образом, она передавалась в личных контрактах. Ученичество было основной формой передачи знаний. Подмастерья осваивали профессию под началом мастера. Согласно соответствующему контракту подручный должен был работать в течение всего периода обучения, а мастер обязан был передавать навыки своему подопечному. В некоторых случаях предполагалась, что обучение оплачивается родителями [Humphries 2003]. Новые технологические ре-

27 Й. Батен и Я. ван Занден уверены, что предложенный ими показатель накопления человеческого капитала является хорошим инструментом прогнозирования последующего роста [Baten, Zanden 2008]. 
шения внедрялись, отлаживались и поддерживались небольшой армией высококвалифицированных специалистов своего дела, в которую входили часовщики и инструментальщики, плотники, изготовители игрушек, стекольных и других дел мастера, способные точно изготавливать необходимые детали, используя правильные измерения и материалы, умеющие читать чертежи и рассчитывать скорость, прекрасно знающие допустимые отклонения, законы сопротивления и трения, а также взаимозависимости механических частей. Эти неизвестные, но талантливые труженики служили опорой для изобретателей и инженеров, составляя, вероятно, 5-10\% общей численности рабочей силы. Благодаря их труду модели и проекты превращались в действующие машины и агрегаты, которыми необходимо было управлять и которые время от времени требовали ремонта. Усилиями этих работников набирала силу относительно небольшая, постепенно прирастающая волна ничем не заменимых и накапливающихся микроизобретений, без которых Англия никогда не превратилась бы в «мастерскую мира» (Workshop of the World).

Большая часть навыков, привнесённых рабочей элитой из числа наиболее умелых мастеров на фабрики, была своего рода наивысшей точкой развития, результатом многовекового процесса накопления экспертных знаний в традиционных ремёслах. Если появление и распространение новых технологий, а также высокая степень взаимодополняемости квалификации и более продуктивного оборудования способствовали повышению ценности человеческого капитала специалистов, это должно было найти отражение в изменениях надбавки к заработной плате представителей рассматриваемой нами группы. Резкое сокращение заработной платы ткачей, занятых на ручных станках, могло компенсироваться растущим спросом на труд высококвалифицированных ремесленников, участвовавших в оснащении прядильного и ткацкого производств новым оборудованием в Ланкашире. Фактические свидетельства носят отрывочный характер, однако имеются некоторые указания на то, что в XVIII веке английские работодатели не жалели усилий на поиск квалифицированных стеклодувов, слесарей или хороших механиков [Musson, Robinson 1960]. Известно, что один из самых концептуально привлекательных тестов, применявшихся в отношении моделей развития в период Промышленной революции человеческого капитала, основывался на изучении изменений в ставках оплаты труда рабочей аристократии по сравнению с основной массой рабочей силы, а также порождённым этими различиями откликом на стороне предложения.

Возможно, нам следовало бы ещё более расширить определение релевантного человеческого капитала. Развитие фабричной системы требовало общих навыков, которые далеко не всегда могли быть приобретены в рамках формального школьного обучения (таких, как дисциплина, пунктуальность и уважение, дополнявших грамотность и способность к количественному мышлению). В одной из недавних работ, посвящённых экономике труда, рассматривались роль и значение некогнитивных навыков [Heckman, Rubinstein 2001]. Использовавшиеся рабочими оборудование и материалы принадлежали капиталисту и были очень дорогими. Владельцам фабрик необходимо было прививать рабочим культуру лояльности и уравновешенности, а также развивать готовность к выполнению инструкций и сотрудничеству с другими работниками. Ещё в процессе обучения ремеслу мастера прилагали немалые усилия для того, чтобы приучить своих подопечных к дисциплине, привычке к которой способствовала работа на дорогостоящем фабричном оборудовании ${ }^{28}$. Помимо этого, более сложные технологии и более глубокое разделение труда создавали между рабочими взаимозависимости, требовавшие такого уровня координации, который едва ли был бы возможен в отсутствие соответствующей готовности и сотрудничества. Надбавка к зарплате за дисциплинированный труд на фабриках была выше, чем премии в других, в большей степени самостоятельных формах занятости, и прибыльность фабричной системы в решающей степени зависела от интенсивности труда [Pollard 1965; Clark 1994]. Вдобавок принятая

28 Не следует приписывать этот научный результат исключительно современной теории. К. Маркс в одном из своих получивших широкую известность пассажей цитирует экономиста Нассау Сениора (1790-1864), рассказывавшего о своём разговоре с одним из промышленников: «Когда земледелец бросает свой заступ, он делает бесполезным на это время капитал в 18 пенсов. Когда один из наших людей оставляет фабрику, он делает бесполезным капитал, который стоил 100 тыс. фунтов стерлингов» [Marx 1967 (1): 405-406]. 
в текстильной промышленности тарифная система, предусматривавшая увеличение заработной платы в зависимости от опыта, предлагала более высокую отдачу для тех, кто был способен культивировать привычку к фабричному труду. На начальной стадии работы, когда неквалифицированные рабочие (такие как кирпичники) могли получать более высокий доход, квалифицированные рабочие эффективно инвестировали в свой собственный человеческий капитал; к 35 годам они могли рассчитывать на то, что их заработная плата в 2,3 раза превысит заработок кирпичника и будет больше, чем у шахтёров [Boot 1995].

Во многом схожие причины определяли важность такой задачи, как наблюдение за рабочими. Если с точки зрения Первой промышленной революции дисциплинарный капитал имел гораздо большее значение, чем традиционно измеряемый уровень образования, то экономические историки должны предложить более полные показатели заработной платы, способные захватывать денежное вознаграждение рабочих, успешно использовавших в своих интересах предъявлявшийся в начале века машин спрос. Кроме того, если дисциплинированные рабочие получали более высокую отдачу, мы должны были бы установить размеры более высоких и растущих надбавок к оплате труда для рабочих, выполнявших помимо основных ещё и руководящие обязанности, а также других членов эволюционирующих иерархий, обеспечивавших в XIX веке бесперебойное функционирование фабрик и заводов. Наиболее очевидный и проверяемый результат развития этой идеи заключается в том, что в начальный период Промышленной революции владельцы фабрик должны были предоставлять преференции в занятости сравнительно более сговорчивым работникам, даже в тех случаях, когда они не обладали высокой квалификацией, в том числе женщинам и детям. Данная практика была весьма распространена на начальной стадии появления новых текстильных фабрик. Аналогично мы могли бы предложить тестирование подхода, основанного на человеческом капитале. Было бы целесообразно сосредоточить внимание на высококвалифицированных рабочих (таких как работники в текстильном производстве), труду которых были посвящены исследования Г. Бута и Т. Леюнига [Boot 1995; Leunig 2001], чтобы выяснить, действительно ли они получали более высокое вознаграждение в результате инвестирования в повышение квалификации (соглашаясь на годы малооплачиваемого обучения на рабочем месте), чем, скажем, ученики ремесленников в традиционных сферах экономики.

Эти наблюдения позволяют предположить, что с точки зрения объяснения европейского перехода к самоподдерживающемуся росту некогнитивные навыки и умения, а также неформальное образование имели большее значение, чем формальное школьное образование и традиционные навыки и умения чтения и письма. В этом смысле различие между образованием и человеческим капиталом, с одной стороны, и культурой - с другой, приобретает все более искусственный характер. Со времени выхода в свет работы о духе капитализма Макса Вебера культура входит в число «обычных подозреваемых», которые могут определять богатство и производительность, с чем согласны и современные учёные (см., например: [Temin 1997; Jones 2006: 126-132]). Сегодня приходит понимание того, что культурное воздействие может быть продемонстрировано и на основе современных данных. В связи с этим допустимо предположение о том, что специалисты по экономической истории, возможно, захотят вновь вернуться к рассмотрению интересующего нас вопроса. В частности, Л. Гуисо, П. Сапиенца и Л. Зингалес продемонстрировали экзогенное воздействие культуры на доход [Guiso, Sapienza, Zingales 2006]. К тому же отличительной чертой культуры является постоянство (см. также: [Tabellini 2006]). В этих исследованиях культура определяется прежде всего с точки зрения ценностей и убеждений отдельных людей. Контролируя эндогенность, насколько это возможно, авторы показывают, что условиями экономического прогресса являются доверие людей друг к другу, убеждённость людей в том, что упорный труд позволит улучшить их положение, а также их вера в то, что формальные государственные институты не несут никакой угрозы. Конечно, мы не имеем возможности привести в подтверждение этого тезиса данные опросов живших в далёком прошлом людей, поэтому новое подкрепление полученных научных результатов потребует немалых усилий. В то же время поразительно, сколь важную роль во 
многих европейских обществах играли в начале Нового времени институты частного права. Обычно они включали культурные убеждения относительно того, что люди должны выполнять данные ими обещания и достойно вести себя. Только такое поведение (а никак не оппортунистическое) было основой для установления повторяющихся, устойчивых взаимодействий между людьми. Репутации были активом, требовавшим в высшей степени осмотрительного управления. В этой интерпретации средние классы коммерческих обществ сделали выбор в пользу в большей степени кооперативного способа поведения, направленного на улучшения по Парето. Возможно, центральный момент этого равновесия заключался в том, что представители среднего класса понимают под «джентльменским поведением». Следование последнему означало, что индивид не заинтересован в получении денег; его более, чем личная выгода, заботит честь. Это вело к ограничению риска обмана [Mokyr 2008]. Вполне вероятно, что подобные социальные нормы имели гораздо более важное значение, чем принятое на европейских рынках принуждение к исполнению законов и контрактов третьей стороной, особенно на рынках кредита и труда.

Однако где находится источник ценностей среднего класса? В своей новаторской работе М. Депке и Ф. Зилиботти сосредоточили внимание на выявлении поведенческих различий между аристократией и средним классом [Doepke, Zilibotti 2008]. Исследователи предложили модель формирования класса, основанную на эндогенных, наследуемых предпочтениях. По мнению Депке и Зилиботти, рост буржуазной элиты в период индустриализации Англии должен рассматриваться как своего рода сюрприз. До начала трансформации все возможные преимущества были на аристократической стороне - денежные средства, политические связи, доступность образования. Но после 1750 г. лишь очень небольшое количество членов старой политической элиты смогли преумножить своё богатство благодаря участию в промышленном производстве. Как полагают Депке и Зилиботти, это было связано с тем, что основной запас «обусловленного терпением капитала» был сосредоточен в «головах и сердцах» другой группы общества - среднего класса. Благодаря множеству культурных практик и норм его представители научились на некоторое время откладывать удовлетворение. Для того чтобы овладеть неким ремеслом, человеку необходимо пройти длительное обучение и приобрести опыт практической деятельности. И только после этого он становился настоящим мастером. В то же время дети старой аристократии на опыте родителей обучались тому, как проводить время в праздности, наслаждаясь ею. Сама аристократическая культура отрицала и упорный труд, и инвестиции. Представители среднего класса, напротив, в течение веков делали сбережения и не жалели усилий для того, чтобы дать образование подрастающим поколениям. Тем самым и был создан финансовый капитал, и взращены ценные культурные свойства. В период Промышленной революции распространение новых технологий привело к значительному увеличению отдачи от умения проявлять терпение. Лучше всего распорядиться ими смогли не представители элиты, а те, кто обладал необходимым умением ждать, настойчиво идти к цели. Депке и Зилиботти убеждены, что культура этого типа сыграла решающую роль в последующем развитии капиталистической индустриализации. С точки зрения этих исследователей, ключевое значение в данном случае имело отсутствие исправно функционировавших финансовых рынков, к которым имел бы доступ средний класс, поскольку наличие сегментированных финансовых рынков является основным условием различий в отдаче за терпение между группами населения.

Концепция обусловленного терпением капитала обещает нам заманчивые перспективы. Возможно, совсем не случайно, что первыми начали осуществлять индустриализацию англичане, которых Адам Смит называл нацией лавочников. В стране сформировалась среда, в которой расцвели буржуазные ценности и практики, рассматривавшиеся как относительно важные. В предшествовавшее Промышленной революции время распространение буржуазных ценностей в Европе сопровождалось повышением интенсивности труда и продолжительности рабочего дня для низших классов, а также усиливающейся ориентацией на саморегулирующийся рынок. Я. де Врис охарактеризовал происходившие в то время изменения как «трудолюбивую революцию» [Vries 1994]. За отмену праздничных дней вы- 
ступили в XVIII веке даже католические иерархи, озаботившиеся необходимостью повышения трудового вклада в церковную экономику [Vries 2008]. Кларку удалось обнаружить фактические данные, свидетельствующие о том, что отличительной чертой наиболее развитых в экономическом отношении частей Европы была более высокая, чем где-либо ещё, интенсивность труда [Clark 1987]. Согласно приведённым Фотхом данным, уже в 1750 г. английский рабочий год был достаточно продолжительным и дальнейшее его увеличение происходило исключительно за счёт уменьшения количества светских и религиозных праздничных дней и традиции невыхода на работу в Святой Понедельник. Эти изменения полностью согласуются с моделью, предложенной Депке и Зилиботти, согласно которой те, у кого относительно ограничены «навыки праздности», в конечном счёте становятся доминирующими классами [Doepke, Zilibotti 2008].

Последние годы отмечены растущим интересом к использованию модели естественного отбора Ч. Дарвина при объяснении культурных изменений. О. Галор и О. Моав разработали модель, в которой в качестве решающей переменной состояния, претерпевшей изменение в доиндустриальный период, используется не численность населения, но «человеческое качество» (генетически заложенное или поведенческое) [Galor, Moav 2002]. Домохозяйства, члены которых наделены в большей степени желательными человеческими характеристиками (образование, правильные гены, экономически выгодные установки), продуцируют более приспособленное к выживанию потомство и постепенно, но неизбежно изменяют состав популяции. Таким образом, в предшествовавший Промышленной революции период качество человеческой популяции постепенно повышалось. Не так давно предложенный Галором и Моавом подход получил ограниченную эмпирическую поддержку. Кларк и Гамильтон обнаружили, что в начале Нового времени дети более богатых и образованных англичан демонстрировали лучшую выживаемость по сравнению со сверстниками [Clark, Hamilton 2006]. Полученные результаты позволяют высказать предположение, согласно которому вместо того, чтобы, рассуждая о восходящем дрейфе, апеллировать к неизмеряемому, безымянному показателю человеческого качества, необходимо всего лишь рассмотреть увеличение доли в популяции людей, научившихся сберегать (и инвестировать), а также тех, кто передал эти ценности своему потомству. С учётом того, что в начальный период Нового времени уровень жизни значительно превысил прожиточный минимум, сформировались все условия для повышения рождаемости. Ограничения на фертильное поведение носили преимущественно социальный и культурный характер (воздействие через нормы брачности). Возможно, эти изменения в составе популяции внесли определённый вклад в снижение в Англии (по сравнению с временами Средневековья) процентных ставок [Clark 1988]. Они уменьшились с 10-11\% в XIII веке до 4\% в XVIII веке. Постепенный рост сбережений, обусловленный структурными эффектами, вызванными увеличением относительного количества более терпеливых людей, является альтернативой теориям, объясняющим рост сбережений особенностями «кальвинистской этики». Кроме того, структурные изменения позволяют нам глубже понять эволюционировавшее демографическое поведение. Как было обнаружено и историками, и экономистами, довольно часто в разных подгруппах наблюдаются различные нормы рождаемости и показатели возраста вступления в первый брак ${ }^{29}$.

Впрочем, не следует воспринимать как установленный факт положение, в соответствии с которым естественный отбор привёл в некоем определимом измерении к улучшению качества популяции в странах, сбросивших с себя «путы» мальтузианской модели ещё до наступления XVIII века. Разделение изменений, обусловленных «врождёнными качествами», и откликов на новые стимулы — в высшей степени трудная проблема. Исходя из того, что в нормальных условиях репродуцирование человеческих особей начинается в возрасте примерно 20 лет (немного раньше или немного позже), любой процесс, в основе которого лежит естественный отбор, требует длительного временного интервала, или уровни рож-

29 В дополнение к исследованию Кларка и Гамильтона [Clark, Hamilton 2006] отметим работы Д. Герлихи, а также Галора и Моава [Herlihy 1997: 56-57; Galor, Moav 2002]. 
даемости должны очень сильно различаться ${ }^{30}$. Нам очень мало известно об относительных различиях в репродуктивном поведении (проявляющихся, например, в различном возрасте вступления в брак) и, экономических успехах различных европейских стран в начальный период Нового времени. Возможно, структурные изменения и играют некую роль, но в настоящее время мы не можем утверждать ничего определённого. Громкие заявления о том, что «выживают только самые богатые», о распространённости этого феномена в Европе и о его отсутствии на Дальнем Востоке [Clark 2007a] опираются на ещё более шаткие основания. Нам необходимо расширить круг фактических свидетельств, подобных тем, которые были собраны Кларком и Гамильтоном, документально подтверждающих различия в показателях рождаемости и выживания на протяжении длительных периодов времени и в разных частях мира.

Специалисты в области эволюции культуры, в том числе Р. Бойд и П. Ричерсон, подчёркивают тот факт, что культурные изменения лишь в малой части являются следствием структурных эффектов естественного отбора [Boyd, Richerson 1985; 2005]. Основными же источниками культурных изменений, по мнению исследователей, выступают обучение и имитация. Безусловно, некая часть культуры передаётся от родителей с генами или в процессе воспитания, однако на всём протяжении своей жизни люди испытывают другие влияния, которые, возможно, и обусловливают их отличия от родителей. Такого рода изменчивость может принимать различные формы, но самой интересной из них является та, которая получила известность как «модельное отклонение», когда индивиды наблюдают за другими людьми, чьи атрибуты рассматриваются как желаемые (например, социальный статус или богатство), тем самым избирая их в качестве собственной ролевой модели. В высокой степени стратифицированном, но мобильном обществе (таком, как британское) действовали сильные стимулы к имитации поведения других людей, занимавших более высокое место в иерархии. Эти стимулы обусловливали повторение наиболее успешными рабочими и ремесленниками поведения представителей буржуазии, уподобление им. Таким образом, рост среднего класса мог происходить быстрее, чем это могло быть предсказано на основании различий в воспроизводстве.

\section{Технологии}

Технологические изменения остаются «становым хребтом» современного экономического роста просто потому, что все другие потенциальные источники повышения продуктивности имеют тенденцию к убывающей отдаче. Накопление капитала, улучшенное распределение ресурсов, выгоды от торговли, более совершенные институты и экономия, обусловленная расширением масштаба производства, все эти факторы будут способствовать увеличению производительности. В то же время отдача от каждого из них постепенно убывает. Условием создания исторически точной картины современного роста является понимание взаимосвязи между наукой и технологией в период Промышленной революции и в дальнейшем. Специализирующиеся на изучении этих проблем учёные-историки разделились: по мнению относительно небольшой группы, наука и научная культура имели решающее значение для успеха Промышленной революции [Musson, Robinson 1969; Rostow 1975; Jacob 1997; Lipsey, Carlaw, Bekar 2005]; большинство же рассматривают роль науки как вторичную и маргинальную [Landes 1969; Hall 1974; Mathias 1979; Gillispie 1980]. Конечно, мы могли бы привести множество примеров важнейшей роли науки и, в частности, математики для некоторых изобретений, сделанных во время Промышленной революции. Но не вызывает сомнений и тот факт, что многие из наиболее известных прорывов в промышленности, особенно те из них, что имели отношение к машинной обработке текстиля, были осуществлены на основе научной базы, значительная часть которой была создана ещё во времена

30 Так как самые ранние доступные нам данные относятся к XVI веку, мы можем быть твёрдо уверены, что воздействие естественного отбора могло распространяться на пять, в лучшем случае на шесть поколений. Учитывая незначительное репродуктивное преимущество, этот период никак нельзя назвать длительным. В то же время результаты недавних генетических исследований позволяют предположить, что «эволюционные изменения в геноме способны объяснить культурные особенности, передававшиеся от поколения к поколению по мере того, как общества адаптировались к различным видам давления» (см.: New York Times. 2006. March 7, 12). 
Архимеда. В других областях (таких, как применение энергии пара, гончарное дело и производство керамических изделий, животноводство) прогресс достигался методом проб и ошибок, а отнюдь не глубоким пониманием физических и биологических процессов.

Дебаты между теми, кто убеждён в том, что наука сыграла ведущую роль в Промышленной революции, и их оппонентами - это больше чем диспут о том, является стакан наполовину пустым или наполовину полным. Изначально «воды» в стакане было на донышке, но начиная с 1750 г., на протяжении более чем полутора столетий, её уровень медленно повышался. Учёные и наука (что не всегда одно и то же) добились впечатляющих успехов в разработке новых производственных технических приёмов (хлорсодержащие отбеливатели, изготовление углекислого натрия, изобретения таких естествоиспытателей, как Б. Франклин, Дж. Пристли, Э. Дэви и Б. Румфорд). Промышленная революция в её классической форме была никак не связана (за некоторыми исключениями) со значительным прогрессом в науке. В то же время едва ли кто-то возьмётся утверждать, что она переросла бы в охвативший всю Европу процесс непрерывного роста в отсутствие расширяющегося корпуса продуцируемых изобретателями и техническими специалистами полезных знаний. Никто не знает, когда точно началось это «сотрудничество». В некоторых областях оно существовало уже в середине XVIII столетия. После 1820-х гг. научные знания становятся важнейшей основой так называемых новых технологических областей, значение которых непрерывно возрастает. К самым замечательным разработкам последних десятилетий классической Промышленной революции относятся электрический телеграф, а также прорыв в химии жирных кислот (использовались в производстве мыла и свечей). Метод проб и ошибок, а также чистая интуиция никогда не уходили со сцены. Однако всё более углублявшиеся знания о том, как и почему функционируют машины и механизмы, значительно облегчили и ускорили процессы усовершенствования новой техники и устранения ошибок, допущенных при её создании. Иначе использование в новых сферах производства и внедрение различных конструктивных изменений едва ли были бы возможны. После 1750 г. в химии и металлургии, в энергетике и пищевой промышленности, в энергомашиностроении, сельском хозяйстве и кораблестроении всё теснее и ближе становились связи между формально образованными людьми, чьи усилия были направлены на изучение и достижение понимания природных явлений и наблюдаемых закономерностей, и людьми, достаток которых зависел от способности с пользой и выгодой использовать полученные учёными результаты. Эти связи продолжают углубляться и развиваться и в наши дни [Mokyr 2002].

Институты, функционирование которых сделало возможным это сотрудничество, со временем становившееся всё более тесным, были подвергнуты детальному исследованию. В данном контексте права на интеллектуальную собственность действительно имели определённое значение, но обращение исключительно к этому аспекту не позволяет объяснить процесс в целом. До настоящего времени единственной публикацией, в которой описывается попытка непосредственного моделирования изменяющихся со временем институциональных параметров, является работа Ч. Джонса [Jones 2001]. Используемые в модели параметры играют важную роль с точки зрения ответа на вопрос о неизбежности Промышленной революции ${ }^{31}$. Введённый Джонсом параметр $\pi \mathrm{t}$, отображающий долю совокупного потребления, назначаемую людям, занятым в сфере генерирования идей, рассчитывается в соответствии с имеющимися фактическими данными. Вообще говоря, модель корректно «отражает рост исследований и разработок, основанных на интенсивном использовании ресурсов. При более высокой частотности ряды демонстрируют весьма странную историю [Jones 2001: 24]; на протяжении XVII века параметр снижается с 0,44 до 0\%; в XVIII веке резко возрастает, а в XIX веке снижается более чем наполовину от достигнутого значения, после чего в ХХ столетии происходит огромный скачок - увеличение в 12 раз, до 5\%. Впрочем, модель Джонса не способна объяснить сложную мотивацию, направлявшую действия представителей сферы идей в прошлом, когда многие естествоиспытатели и изобретатели были за-

31 Предложенный Джонсом параметр $\pi$ определяет долю совокупного дохода, получаемого занятыми в сфере идей; в состоянии равновесия эта доля равна той части труда, которая направляется в экономике на продуцирование новых идей. 
интересованы не только в финансовых выгодах, но и в подаче «сигналов», подобно разработчикам современного свободного программного обеспечения [Lerner, Tirole 2004]. В моделях, предназначенных для объяснения технологического роста в эпоху Промышленной революции, необходимо учитывать использовавшиеся в двух отдельных секторах сферы идей различные способы приобретения прав собственности. В то время как предписывающие знания, то есть различные технические приёмы, могли быть защищены патентами, и их собственники получали определённые права на изобретения, в области утвердительных знаний (знания в виде высказываний, суждений) их «владелец» не приобретал никаких исключительных прав, кроме известности первооткрывателя той или иной теории. Поэтому одним из условий достижения понимания факторов технологического роста в период Промышленной революции является эксплицитное признание обратной связи между названными выше двумя формами знаний [Mokyr 2002 ] (см. также: [Dasgupta, David 1994]). До 1850 г. учёные в редких случаях проявляли интерес к материальным выгодам, которые могли принести им научные открытия. Они стремились не столько к прибыли, сколько к славе. «Джентльмены-философы» не желали «зарабатывать на пропитание» своими открытиями и настороженно относились к любому из тех коллег, кто поступал иначе [Bowler, Morus 2005: 320-321].

Следует отметить, что, согласно произведённым не так давно оценкам, доля доходов от изобретений, достающаяся в современной Америке самим изобретателям, составляет всего лишь около $2,2 \%$ [Nordhaus 2004]. Маловероятно, что во времена Промышленной революции этот показатель был выше. Патентная система является центральным сюжетом, однако по вопросу о её воздействии на процесс технологического прогресса во время Промышленной революции по-прежнему ведётся множество споров. Функционирование патентной системы означает, что изобретатели получают монополию на свои изобретения. В то же время разного рода нарушения и другие системные неудачи означают, что преимущества первопроходца и «старомодное» правительство, а также награды со стороны частного сектора играли не менее важную роль, чем рента, которую получали изобретатели ${ }^{32}$. Английскую патентную систему никак нельзя было назвать дружественной по отношению к пользователю: заявка на получение патента стоила довольно дорого; к тому же нередко возникали проблемы с защитой патентов от нарушителей прав изобретателей [Dutton 1984; Khan, Sokoloff 1998]. Патентное законодательство подвергалось всеобщему порицанию как неэффективное с точки зрения защиты подавляющего большинства изобретателей, а также критиковалось за высокую цену охраны прав [MacLeod, Nuvolari 2007]. Значительная часть изобретений (даже самые успешные из них) не была защищена патентами [Moser 2005]. Однако то обстоятельство, что английская система в меньшей степени, чем соответствующая американская, поощряла потенциальных изобретателей к действию, по всей видимости, не оказало отрицательного воздействия на технологическое лидерство Великобритании до 1850 г. Всегда называвший вещи своими именами Чарльз Бэббидж охарактеризовал патентное право как мошенническую лотерею, в которой гении не получают ничего, а все призы достаются жуликам [Babbage 1830: 333, 321]. Возможно, что не менее эффективными с точки зрения побуждения к генерированию новых идей, чем защита со стороны патентной системы, были денежные вознаграждения за изобретения (назначавшиеся, например, английским парламентом) [Brunt, Lerner, Nicholas 2008]. Было ли в патентной системе хоть что-то хорошее? Да: ожидаемая (ex ante) вера в то, что успешное изобретение способно принести отдачу нескольким счастливчикам (то есть она сыграла положительную стимулирующую роль).

Впрочем, в рассматриваемом нами контексте гораздо более глубокую и всеохватывающую роль сыграл другой социальный феномен. Имеются в виду непрерывно растущие информационные потоки и улучшающиеся взаимодействия между теми, кто изготавливал различные вещи (предприниматели и инженеры), и теми, кто в них разбирался (естествоиспытатели). Это означало не только расширение

32 Функционированию патентной системы в Англии посвящена обширная литература; для первого знакомства мы рекомендуем следующие работы: [Dutton 1984; MacLeod 1988; MacLeod, Nuvolari 2007]. 
возможности доступа к знаниям для тех, кто мог бы найти им наиболее полезное применение; научная повестка дня во всё большей степени формировалась в соответствии с практическими потребностями экономики. Мосты, наводившиеся между учёными и фабрикантами, принимали самые разные формы - от письменных технических руководств и учебников до академий и научных обществ, где представители сторон общались друг с другом и обменивались идеями. Уже в последние десятилетия XVIII века самым обычным явлением стали консультации, за которыми обращались к учёным промышленники и фермеры, нуждавшиеся в усовершенствованных отбеливателях, более мощных двигателях или эффективных удобрениях.

К 1815 г. потребность в таком сотрудничестве получила всеобщее признание, и европейские экономики уже конкурировали друг с другом в стремлении побудить учёных и производственников к взаимодействию. Примерами того, что частные институты способны решить эту задачу даже в стране, где люди более всего доверяют индивидуальным инициативам, стали в Англии учреждённое в 1754 г. Королевское общество искусств (Society of Arts) и основанный в 1799 г. Королевский институт (Royal Institution), а также механические институты (Mechanics Institutes) (первый из них был создан в 1804 г. Джорджем Биркбеком). Одновременно в стране функционировали множество менее формальных институтов. Самым известным среди них является Лунное общество Бирмингема (Lunar Society of Birmingham), объединявшее лучших учёных Англии и наиболее известных предпринимателей и инженеров. Не менее важную роль сыграли не столь известное Спиталфилдское математическое общество (Spitalfields Mathematical Society), основанное в 1717 г., и лондонская Чептерская кофейня (London Chapter Coffee House), которая в 1780-х гг. была любимым местом встреч членов Королевского общества (Royal Society). Собиравшиеся в кофейне учёные мужи вели продолжительные дискуссии, обсуждая практические вопросы использования пара и различных химических веществ [Levere, Turner 2002]. Во Франции, в Германии и Нижних землях (Исторические Нидерланды) государство играло более активную роль в организации сотрудничества учёных и промышленников (см., например: [Lenoir 1998]). Впрочем, далеко не все эти усилия позволили добиться безоговорочного успеха. Например, в исследованиях, направленных на получение практических результатов, выпускники парижской Политехнической школы (École Polytechnique) зачастую демонстрировали лишь способность к абстракциям и склонность к формальному подходу. Система немецких университетов в целом оказалась значительно более консервативной, чем того ожидало правительство, и тамошние преподаватели никак не желали участвовать в поиске способов практического применения научных знаний. По инициативе государства были созданы новые и более эффективные институты, а старые университеты были в конце концов реформированы ${ }^{33}$. Прошедшие после 1815 г. несколько десятилетий стали окончательным триумфом последователей философии Ф. Бэкона, послужившей идеологической основой создания в 1660 г. Лондонского королевского общества по развитию знаний о природе (The Royal Society of London for the Improvement of Natural Knowledge). Условием этого торжества были осуществлённые в Европе институциональные изменения в сфере накопления и распространения практически полезных знаний, хотя для них подмостками (scaffolds) (термин Норта) служила идеология Просвещения, основывавшаяся на неколебимой вере в торжество разума, а также на защите конкретных программ, направленных на обеспечение этого прогресса.

Моделирование производства новых идей представляет собой главную трудность с точки зрения создания моделей роста; в свою очередь, эндогенные модели роста с неизбежностью упрощают богатство исторической картины. Неудивительно, что исследователи не справляются с анализом рискованного процесса изобретательства, представляя сферу производства идей, скорее, как лотерею, нежели как об-

33 Немецкие университеты были вынуждены участвовать во всё более обострявшейся конкуренции с техническими колледжами (technische Hochschule), первый из которых был учрежден в 1825 г. в Карлсруэ. Во Франции с целью придания образованию более прикладного характера были образованы новые высшие учебные заведения - школы, такие как Национальная высшая школа искусств и ремесел (Ecole Nationale Supérieure d'Arts et Métiers). 
ласть деятельности ${ }^{34}$. Авторы некоторых моделей явным образом ссылаются на «количество произведённых идей», однако эта концепция рассматривается нами как в высшей степени проблематичная. И не только потому, что идеи не подчиняются правилам арифметики, но и в силу того, что очень многие из них были мёртворождёнными, ошибочными или просто плодом фантазии. В то же время большая часть новых технологий была результатом незначительных, но накапливавшихся усовершенствований, осуществлявшихся благодаря опыту и обучению в действии (learning-by-doing) квалифицированных мастеров, а не разного рода когнитивным озарениям. Конечно, технологические изменения в период Промышленной революции происходили не только благодаря этим «ремесленным» достижениям, но историки совершенно справедливо подчёркивают их важное значение [Berg 2007].

\section{Заключение: недопонимание как источник прогресса}

Нередко экономисты-теоретики и историки экономики, изучающие переход к самоподдерживающемуся росту, ведут себя как представители двух кланов, не имеющих между собой ничего общего, кроме предмета исследования. Это разделение препятствует дальнейшему прогрессу в достижении понимания того, как именно произошло переключение «от Мальтуса к Солоу». Мы рассмотрим несколько отдельных источников недопонимания между учёными и представим предложения относительно будущих исследований, призванные урегулировать отношения между «кланами» и увеличить интеллектуальные выгоды от обмена мнениями представителей разных «племён».

Специалисты по экономической теории, труды которых посвящены исследованиям долгосрочного экономического роста, во многих случаях применяют свои модели к временам индустриализации Англии, рассматривая и индустриализацию в Англии, и саму Англию как классический, первый пример Промышленной революции. В результате они вынуждены игнорировать или принижать значение других, «неудобных» фактов экономической истории, свидетельствующих о том, «как всё было на самом деле» («wie es wirklich gewesen ist»). Например, согласно предлагаемой Джонсом модели, во время перехода продолжительность рабочего дня снижается [Jones 2001], в то время как в действительности она, вероятно, возросла. В моделях, созданных в традиции Лукаса и Беккера, делается акцент на повышении спроса и отдачи на человеческий капитал, несмотря на ограниченное количество соответствующих фактических свидетельств. Асемоглу, Джонсон и Робинсон подчёркивают важность ограничений на исполнительную власть в начале Нового времени в Европе, несмотря на отсутствие данных о том, что действия сдерживающих её групп способствовали экономическому росту. Этот перечень может быть расширен, однако его главное предназначение - наглядность.

Специалисты по экономической истории не преминули указать на наиболее очевидные противоречия, подчёркивая, что «в большинстве моделей роста Промышленная революция имеет лишь отдалённое сходство с происходившими в XVIII веке в Англии экономическими событиями» [Voth 2003]. Мы убеждены, что дискуссия должна быть продолжена. Многие теоретики роста стремятся применять свои модели к классической английской Промышленной революции [Hansen, Prescott 2002; Lucas 2002; Galor 2005]. Но логика, которой следует большинство универсальных моделей роста, не позволяет использовать их в качестве объясняющего инструментария. Эти модели гораздо лучше соответствуют начальному периоду Нового времени. В то же время критика моделей экономическими историками во многом обусловлена исповедуемым ими чрезмерно узким подходом. Если мы расширим временны́е границы периода, в котором анализируются демографические изменения, и будем изучать накопление человеческого капитала в течение длительного времени, рассматривая в качестве релевантного набора

34 Вне всяких сомнений, было бы лучше, если бы этот аспект технологического прогресса был подвергнут анализу специалистами по поведенческой экономике и теории принятия решений, работающими с моделями, в которых люди систематически переоценивают свои шансы на достижение успеха. Это понимал ещё Адам Смит, писавший: «Их абсурдная вера в собственную счастливую судьбу... носит еще более всеобщий характер [по сравнению с завышенной оценкой людьми своих способностей]... каждый человек в большей или меньшей степени переоценивает свои шансы на получение прибыли и... недооценивает шансы понести убытки» [Smith 1966: 120]. 
навыков не только грамотность (ей традиционно уделяется повышенное внимание), но и другие умения, многие очевидные сегодня противоречия смягчатся. Временем постепенного схождения на нет мальтузианского режима стали 1500-1800 гг, и многие релевантные изменения в человеческом капитале начались, вероятно, после Реформации. Рассуждая в том же ключе, заметим, что если специалисты по экономической истории и экономисты-теоретики будут уделять большее внимание некогнитивным навыкам и таким культурным особенностям личности, как терпение, рассудительность и дисциплина, то перед теоретиками откроется возможность построения новых моделей, в большей степени соответствующих историческим данным. Универсальные теории роста обладают значительной объясняющей силой, особенно те из них, в которых рассматривается включающий две фазы переход к современному росту (как в работе: [Galor, Moav 2002]), когда сначала происходит ослабление мальтузианских ограничений, а впоследствии большую важность приобретает человеческий капитал.

Длительность рассматриваемого периода времени - отнюдь не единственный важный источник недопонимания между учёными. Как подчёркивали немецкие философы Г. Риккерт и В. Виндельбанд, история идеографична, то есть она стремится объяснить уникальное. Теоретики же в силу необходимости номотетичны, то есть заняты поиском всеобщих законов. В применении к дискуссии об английской Промышленной революции это означает, например, что Хансен и Прескотт рассматривают её как иллюстрацию модели, которая может быть применена к Европе в целом (и, конечно, ко всему миру) [Hansen, Prescott 2002], а историки очень часто концентрируют внимание на эмпирически точном описании отдельных случаев. В равной степени проблематичной является тенденция к изучению логики исторических трудов с точки зрения кросс-секционного анализа. Немногие историки сумели устоять перед искушением и не потребовать демонстрации предсказательных возможностей для нашей собственной периодизации экономического развития от моделей, предназначенных исключительно для ответа на решающий вопрос о том, почему первой «пришла» Англия, а не Франция или Китай [Crafts 1995; Broadberry 2007]. Модели, рассматриваемые в работах Кремера, а также Галора и Вейла [Kremer 1993; Galor, Weil 2000], применимы к миру в целом. Тем не менее специалисты по экономической истории критикуют эндогенные модели роста за то, что они не способны предложить убедительных объяснений расхождения в доходах между странами. Очевидно, что в данном случае идёт охота на носорога с помощью предварительно заострённых плодов киви.

Впрочем, и экономисты-теоретики, со своей стороны, не уделяют должного внимания важнейшим применениям кросс-секционного анализа для установления периодизации моментов, когда темпы экономического роста неожиданно возрастали ${ }^{35}$. Например, Р. Холл и Ч. Джонс привели в своей работе документальные свидетельства о значительных различиях в объёмах выпуска продукции в расчёте на душу населения между богатыми и бедными странами [Hall, Jones 1999]. Исследователи приходят к заключению, что эти различия не могут быть объяснены ни различиями в капитале, ни различиями в человеческом капитале; ответственность за них должны нести совокупная факторная производительность и «социальная мощность». Базисные модели наполняются смыслом только тогда, когда мы исходим из допущения, что экономики достигли устойчивого состояния, или они располагают возможностями для быстрого перехода в него. В большинстве работ, посвящённых росту и использующих набор данных А. Саммерса и Р. Хестона, разделяется это допущение. Однако когда мы заглядываем за исторический горизонт, то приходим к выводу, что одним из самых поразительных феноменов является то, что для «побега» из мальтузианского мира потребовался очень короткий отрезок времени. Например, если мы возьмём последние 200 лет, то увидим, что в разных странах «взлёт» в направлении самоподдерживающегося роста (мы не принимаем во внимание такие досадные возвраты к прошлому, как в Аргентине) происходил в различное время. Оказалось, что объяснить это очень трудно. Со временем более позднее начало экономического роста приведёт к появлению модели различий в производительности, принимающей вид, обратный U-форме. Смягчение допущения о том, что экономики на-

35 Исключениями из общего ряда являются работы Н. Фойхтлендера и Г. Фотха, которые предлагают модели, призванные частично объяснить «Первое великое расхождение» между Европой и Китаем [Voigtländer, Voth 2006; 2008]. 
ходятся в состоянии равновесия, и сосредоточение внимания на том, что позволяет им вступить в фазу быстрого, самоподдерживающегося роста, позволяет найти ответы на некоторые ключевые загадки, содержащиеся в текущей литературе на тему роста [Ngai 2004]. Относительно небольшие недостатки, несообразности в том случае, если они задерживают переход к современному росту, способны привести к весьма значительным различиям в показателях объёма выпуска продукции в расчёте на душу населения. Следовательно, нам необходим целый комплекс теорий, моделирующих экономическую динамику: что стоит за такими феноменами, как распределение во времени, задержки во времени и значительный по историческим меркам разрыв между предшествовавшими историческими изменениями и началом современного роста? Это означает, что экономисты-теоретики могут, как и прежде, черпать вдохновение для своих моделей в выводах кросс-секционного анализа о расходящихся траекториях роста, однако экономическая история предлагает нечто гораздо большее. Более тесное сотрудничество между теми, кто пытается распознать всеобщие законы, и теми, кто пристально изучает исторические данные, способно принести очень высокую отдачу. Только когда мы поймём, какие недостатки и определяющие отставание во времени влияния продуцируют временну́ю матрицу экономического взлёта, наблюдаемого нами на протяжении последних двух столетий, у нас появятся основания для того, чтобы заявить о достижении того полного понимания, которое предполагает использование термина «универсальная теория роста».

\section{Лumepamypa}

A'Hearn B., Baten J., Crayen D. 2009. Quantifying Quantitative Literacy: Age Heaping and the History of Human Capital. Journal of Economic History. 69: 783-808.

Acemoglu D., Cantoni D., Johnson S., Robinson J. A. 2008. The Consequences of Radical Reform: The Economic Consequences of the French Revolution. Mimeo.

Acemoglu D. et al. 2008. The Consequences of Radical Reform: The Economic Consequences of the French Revolution. Mimeo.

Acemoglu D., Johnson S. 2005. Unbundling Institutions. Journal of Political Economy. 113: 949-995.

Acemoglu D., Johnson S., Robinson J. A. 2001. The Colonial Origins of Comparative Development: An Empirical Investigation. American Economic Review. 91: 1369-1401.

Acemoglu D., Johnson S., Robinson J. A. 2005. The Rise of Europe: Atlantic Trade, Institutional Change and Economic Growth. American Economic Review. 95: 546-579.

Acemoglu D., Robinson J. A. 2000. Why Did the West Extend the Franchise? Quarterly Journal of Economics. 115: 1167-1199.

Acemoglu D., Robinson J. A. 2005. Economic Origins of Dictatorship and Democracy. Cambridge, MA: Cambridge University Press.

Acemoglu D., Robinson J. A. 2006. Persistence of Power Elites and Institutions. American Economic Review. 98: 267-93.

Acemoglu D., Zilibotti F. 1997. Was Prometheus Unbound by Chance? Risk, Diversification, and Growth. Journal of Political Economy. 105: 709-751. 
Allen R. C. 2001. The Great Divergence in European Wages and Prices from the Middle Ages to the First World War. Explorations in Economic History. 38: 411-447.

Alesina A. S. et al. 1996. Political Instability and Economic Growth. Journal of Economic Growth. 2: 189213.

Alter G. 1992. Theories of Fertility Decline: A Nonspecialist's Guide to the Current Debate. In: Gillis J. R., Tilly L. A., Levine D. (eds). The European Experience of Declining Fertility, 1850-1970. Cambridge, MA: Blackwell.

Baten J., Zanden J. L. van. 2008. Book Production and the Onset of Modern Economic Growth. Journal of Economic Growth. 13: 217-235.

Babbage C. 1830. Reflexions on the Decline of Science in Britain and on Some of Its Causes. Quarterly Review. 43: 307-342.

Becker G. S., Barro R. J. 1988. A Reformulation of the Economic Theory of Fertility. Quarterly Journal of Economics. 103: 1-25.

Becker G. S., Murphy K., Tamura R. 1990. Human Capital, Fertility, and Economic Growth. Journal of Political Economy. 98: S12-S37.

Beik W. 2005. Review Article: The Absolutism of Louis XIV as Social Collaboration. Past and Present. 188: 195-224.

Berg M. 2007. The Genesis of Useful Knowledge. History of Science. 45: 123-134.

Bogart D. 2005a. Did Turnpike Trusts Increase Transportation Investment in Eighteenth-Century England? Journal of Economic History. 65: 439-468.

Bogart D. 2005b. Turnpike Trusts and the Transportation Revolution in Eighteenth-Century England. Explorations in Economic History. 42: 479-508.

Boot H. M. 1995. How Skilled Were Lancashire Cotton Factory Workers in 1833? Economic History Review. 48: 283-303.

Boot H. M. 1999. Real Incomes of the British Middle Class, 1760-1850. Economic History Review. 52: 638-668.

Boucekkine R., De la Croix D., Peeters D. 2007. Early Literacy Achievements, Population Density and the Transition to Modern Growth. Journal of the European Economic Association. 5: 183-226.

Bowler P. J., Morus I. R. 2005. Making Modern Science. Chicago: University of Chicago Press.

Boyd R., Richerson P. J. 1985. Culture and the Evolutionary Process. Chicago: University of Chicago Press.

Boyd R., Richerson P. J. 2005. Not by Genes Alone: How Culture Transformed Human Evolution. Chicago: University of Chicago Press. 
Broadberry S. N. 2007. Recent Developments in the Theory of Very Long Run Growth: A Historical Appraisal, Warwick Economics Research Paper. 818. URL: http//www2.warwick.ac.uk/fac/soc/economics/research/ workingpapers/publications/twerp_818.pdf

Brown J. C., Guinnane T. W. 2002. Fertility Transition in a Rural Catholic Population: Bavaria 1880-1910. Population Studies. 56: 35-50.

Brunt L., Lerner J., Nicholas T. 2008. Inducement Prizes and Innovation. Mimeo. Cambridge, MA: Harvard Business School.

Cervellati M., Sunde U. 2005. Human Capital Formation, Life Expectancy, and the Process of Economic Development. American Economic Review. 95: 153-167.

Chesnais J.-C. 1992. The Demographic Transition. Oxford: Oxford University Press.

Clark G. 1987. Productivity Growth without Technical Change in European Agriculture before 1850. Journal of Economic History. 47: 419-432.

Clark G. 1988. The Cost of Capital and Medieval Agricultural Technique. Explorations in Economic History. 25: $265-294$.

Clark G. 1994. Factory Discipline. Journal of Economic History. 54: 128-163.

Clark P. 2000. British Clubs and Societies, 1580-1800: The Origins of an Associational World. Oxford: Clarendon Press.

Clark G. 2005. The Condition of the Working Class in England, 1209-2004. Journal of Political Economy. 113: $1307-1340$.

Clark G. 2007a. A Farewell to Alms. Princeton: Princeton University Press.

Clark G. 2007b. The Long March of History: Farm Wages, Population, and Economic Growth, England 12091869. Economic History Review. 60: 97-135.

Clark G., Hamilton G. 2006. Survival of the Richest: The Malthusian Mechanism in Pre-Industrial England. Journal of Economic History. 66: 707-736.

Cleland J., Wilson C. 1987. Demand Theories of the Fertility Transition: An Iconoclastic View. Population Studies. 41: 5-30.

Coale A., Watkins S. C. (eds). 1986. The Decline of Fertility in Europe. Princeton: Princeton University Press.

Crafts N. F. R. 1977. The Industrial Revolution in England and France: Some Thoughts on the Question, Why Was England First? Economic History Review. 30: 429-441.

Crafts N. F. R. 1985. British Economic Growth During the Industrial Revolution. Oxford: Oxford University Press. 
Crafts N. F. R. 1995. Exogenous or Endogenous Growth? The Industrial Revolution Reconsidered. Journal of Economic History. 55: 745-772.

Crafts N. F. R., Mills T. 2009. From Malthus to Solow: How the Malthusian. Economy Really Evolved. Journal of Macroeconomics. 31: 68-93.

Dam K. W. 2005. The Law-Growth Nexus: The Rule of Law and Economic Development. Washington: Brookings Institution Press.

Dasgupta P., David P. A. 1994. Toward a New Economics of Science. Research Policy. 23: 487-521.

Daudin G. 2007. Traders, Intercontinental Trade, and Growth before the Industrial Revolution. Mimeo.

DeLong J. B., Shleifer A. 1993. Princes and Merchants: European City Growth before the Industrial Revolution. Journal of Law and Economics. 36: 671-702.

De la Croix D. 2008. Adult Longevity and Economic Take-off: From Malthus to Ben-Porath. Mimeo.

Doepke M. 2004. Accounting for Fertility Decline during the Transition to Growth. Journal of Economic Growth. 9: 347-383.

Doepke M., Zilibotti F. 2005. The Macroeconomics of Child Labor Regulation. American Economic Review. 95: $1492-1524$.

Doepke M., Zilibotti F. 2008. Occupational Choice and the Spirit of Capitalism. Quarterly Journal of Economics. 123: 747-793.

Drelichman M., Voth H.-J. 2008. Debt Sustainability in Historical Perspective: The Role of Fiscal Repression. Journal of the European Economic Association. 6: 657-667.

Dutton H. 1984. The Patent System and Inventive Activity during the Industrial Revolution 1750-1852. Manchester: Manchester University Press.

Ellickson R. C. 1991. Order without Law: How Neighbors Settle Disputes. Cambridge, MA: Harvard University Press.

Epstein S. R. 2000. Freedom and Growth: Markets and States in Pre-modern Europe. New York: Routledge.

Feinstein C. H. 1972. National Income, Expenditure and Output of the United Kingdom, 1855-1965. Cambridge, MA: Cambridge University Press.

Feinstein C. H. 1978. Capital Formation in Great Britain. In: Mathias P., Postan M. M. (eds). The Cambridge Economic History of Europe. 8 (1). The Industrial Economies: Capital Labour and Enterprise. Cambridge, MA: Cambridge University Press.

Feinstein C. H. 1988. Review: The Rise and Fall of the Williamson Curve. Journal of Economic History. 48: 699-729.

Flora P., Kraus F., Pfenning W. 1983. State, Economy and Society in Western Europe 1815-1975. 1. Chicago: St. James Press. 
Galloway P. R. 1988. Basic Patterns in Annual Variations in Fertility, Nuptiality, Mortality, and Prices in Preindustrial Europe. Population Studies. 42: 275-302.

Galor O. 2005. From Stagnation to Growth: Unified Growth Theory. In: Aghion P., Durlauf S. N. (eds). Handbook of Economic Growth. 1A. Amsterdam: North Holland Press.

Galor O., Moav O.. 2002. Natural Selection and the Origins of Economic Growth. Quarterly Journal of Economics. 117: 1133-1191.

Galor O., Weil D.N. 2000. Population, Technology, and Growth: From Malthusian Stagnation to the Demographic Transition and Beyond. American Economic Review. 90: 806-828.

Gillispie C. C. 1980. Science and Polity in France at the End of the Old Regime. Princeton: Princeton University Press.

Glaeser E. et al. 2004. Do Institutions Cause Growth? Journal of Economic Growth. 9: 271-303.

Greif A. 2005. Commitment, Coercion, and Markets: The Nature and Dynamics of Institutions Supporting Exchange. In: Menard C., Shirley M. M. (eds). Handbook for New Institutional Economics. Norwell, MA: Kluwer Academic.

Greif A. 2006. Institutions and the Path to the Modern Economy: Lessons from Medieval Trade. Cambridge, MA: Cambridge University Press.

Guiso L., Sapienza P., Zingales L. 2006. Does Culture affect Economic Outcomes? NBER Working Paper. 11999.

Hajnal J. 1965. European Marriage Pattern in Historical Perspective. In: Glass D. V., Eversley D. E. C. (eds). Population in History. London: Arnold.

Hall R. A. 1974. What Did the Industrial Revolution in Britain Owe to Science? In: McKendrick N. (ed.). Historical Perspectives: Studies in English Thought and Society. London: Europa Publications.

Hall R. E., Jones C. I. 1999. Why Do Some Countries Produce So Much More Output per Worker than Others? Quarterly Journal of Economics. 114: 83-116.

Hansen G. D., Prescott E. C. 2002. Malthus to Solow. American Economic Review. 92: 1205-1217.

Hansson G., Olsson O. 2006. Country Size and the Rule of Law: Resuscitating Montesquieu. Mimeo. Göteborg: Göteborg University.

Heckman J. J., Rubinstein Y. 2001. The Importance of Noncognitive Skills: Lessons from the GED Testing Program. American Economic Review. 91: 145-149.

Herlihy D. 1997. The Black Death and the Transformation of the West. Cambridge, MA: Harvard University Press.

Hicks J. 1969. A Theory of Economic History. Oxford: Clarendon. 
Humphries J. 2003. English Apprenticeships: A Neglected Factor in the First Industrial Revolution. In: David P. A., Thomas M. (eds). The Economic Future in Historical Perspective. Oxford: Oxford University Press.

Humphries J. 2007. «Because They Are too Menny...» Children, Mothers and Fertility Decline — The Evidence from Working-Class Autobiographies of the Eighteenth and Nineteenth Centuries. In: Janssens A. (ed.) Gendering the Fertility Decline in the Western World. Bern; New York: Peter Lang.

Jacob M. C. 1997. Scientific Culture and the Making of the Industrial Wes., 2nd ed. New York: Oxford University Press.

Jones C. I. 2001. Was the Industrial Revolution Inevitable? Economic Growth over the Very Long Run. Advances in Macroeconomics. 1: 1-42.

Jones E. L. 1981. The European Miracle. Cambridge, MA: Cambridge University Press.

Jones E. L. 2006. Cultures Merging. Princeton: Princeton University Press.

Kelley M. 1976. The Wealth of Nations. Chicago: University of Chicago Press.

Kelly M. 1997. The Dynamics of Smithian Growth. Quarterly Journal of Economics. 112: 939-964.

Kelly M. 2005. Climate and Pre-Industrial Growth. Mimeo. Dublin: University College Dublin.

Keynes J. M. 1930. Economic Possibilities for Our Grandchildren. The Nation and Atheneum. 9: 329.

Khan B. Z., Sokoloff K. L. 1998. Patent Institutions, Industrial Organization, and Early Technological Change: Britain and the United States, 1790-1850. In: Berg M., Bruland K. (eds). Technological Revolutions in Europe. Cheltenham: Edward Elgar.

Kirby P. 1999. The Historic Viability of Child Labor and the Mines Act of 1842. In: Lavalette M. (ed.) A Thing of the Past? Child Labour in Britain in the Nineteenth and Twentieth Centuries. Liverpool: Liverpool University Press.

Kremer M. 1993. Population Growth and Technological Change: One Million B.C. to 1990. Quarterly Journal of Economics. 108: 681-716.

Kuznets S. 1955. Economic Growth and Income Inequality. American Economic Review. 45: 1-28.

Kuznets S. 1974. Population, Capital and Economic Growth: Selected Essays. London: Heinemann; 165-84.

Landes D. 1969. The Unbound Prometheus: Technological Change and Industrial Development in Western Europe from 1750 to the Present. Cambridge, MA: Cambridge University Press.

Lee R. D. 1981. Short-Term Variation: Vital Rates, Prices, and Weather. In: Wrigley E. A., Schofield R. S. (eds). The Population History of England, 1541-1871: A Reconstruction. London: Edward Arnold.

Lee R. D. 1987. Population Dynamics of Humans and Other Animals. Demography. 24: 443-465. 
Lee R. D. 2003. The Demographic Transition. Three Centuries of Fundamental Change. Journal of Economic Perspectives. 17: 167-90.

Lee R. D., Anderson M. 2002. Malthus in State Space: Macroeconomic-Demographic Relations in English History, 1540 to 1870. Journal of Population Economics. 15: 195-220.

Lenoir T. 1998. Revolution from Above: The Role of the State in Creating the German Research System, 1810-1910. American Economic Review. 88: 22-27.

Lerner J., Tirole J. 2004. The Economics of Technology Sharing: Open Source and Beyond. NBER Working Paper. 10956.

Leunig T. 2001. Piece Rates and Learning: Understanding Work and Production in the New England Textile Industry a Century Ago. Mimeo. London: London School of Economics.

Leunig T. 2006. Time is Money: A Reassessment of the Passenger Social Savings from Victorian British Railways. Journal of Economic History. 66: 635-673.

Levere T. H., Turner G. L'E. 2002. Discussing Chemistry and Steam: The Minutes of a Coffee House Philosophical Society 1780-1787. Oxford: Oxford University Press.

Lin J. Y. 1995. The Needham Puzzle: Why the Industrial Revolution Did Not Originate in China. Economic Development and Cultural Change. 43: 269-292.

Lipsey R. G., Carlaw K. I., Bekar C. T. 2005. Economic Transformations: General Purpose Technologies and Long-Term Economic Growth. Oxford: Oxford University Press.

Lucas R. E. 2002. The Industrial Revolution: Past and Future. In: Lucas R. E. Lectures on Economic Growth. Cambridge, MA: Harvard University Press.

MacLeod C. 1988. Inventing the Industrial Revolution: The English Patent System, 1660-1800. Cambridge, MA: Cambridge University Press.

MacLeod C., Nuvolari A. 2007. Inventive Activities, Patents, and Early Industrialization: A Synthesis of Research Issues. Mimeo.

Marx K. 1967 (1867). Das Kapital. English Trans. Capital. By S. Moore; E. Aveling. 2 Vols. New York: International Publishers.

Mathias P. 1979. The Transformation of England. New York: Columbia University Press.

Michie R. C. 1999. The London Stock Exchange: A History. Oxford: Oxford University Press.

Michie R. C. 2000. The Development of London as a Financial Centre. London: Tauris.

Mitch D. F. 1984. Underinvestment in Literacy: The Potential Contribution of Government Involvement in Elementary Education to Economic Growth in 19th-Century England. Journal of Economic History. 44: $557-566$. 
Mitch D. F. 1991. The Rise of Popular Literacy in Victorian England: The Influence of Private Choice and Public Policy. Philadelphia: University of Pennsylvania Press.

Mitch D. F. 1993. The Role of Human Capital in the First Industrial Revolution. In: Mokyr J. (ed.) The British Industrial Revolution: An Economic Perspective. Boulder: Westview.

Mitch D. F. 1999. The Role of Education and Skill in the First Industrial Revolution. In: Mokyr J. (ed.) The British Industrial Revolution: An Economic Perspective. Boulder: Westview; 241-279.

Moehling C. M. 1999. State Child Labor Laws and the Decline of Child Labor. Explorations in Economic History. 36: 72-106.

Mokyr J. 1977. Demand vs Supply in the Industrial Revolution. Journal of Economic History. 37: 981-1008.

Mokyr J. 1985. Why Ireland Starved. London: Allen and Unwin.

Mokyr J. 1987. Has the Industrial Revolution Been Crowded Out? Explorations in Economic History. 24: 293-319.

Mokyr J. 1990. The Lever of Riches: Technological Creativity and Economic Progress. New York: Oxford University Press.

Mokyr J. 1993. Editor's Introduction: The New Economic History and the Industrial Revolution. In: Mokyr J. (ed.) The British Industrial Revolution: An Economic Perspective. Boulder: Westview.

Mokyr J. 1994. Technological Change, 1700-1830. In: Floud R., McCloskey D. (eds). The Economic History of Britain Since 1700. Volume 1: 1700-1860. 2nd ed. Cambridge, MA: Cambridge University Press.

Mokyr J. 2002. The Gifts of Athena: Historical Origins of the Knowledge Economy. Princeton: Princeton University Press.

Mokyr J. 2006. The Great Synergy: The European Enlightenment as a Factor in Modern Economic Growth. In: Dolfsma W., Soete L. (eds). Understanding the Dynamics of a Knowledge Economy. Cheltenham: Edward Elgar.

Mokyr J. 2008. The Institutional Origins of the Industrial Revolution. In: Helpman E. (ed.) Institutions and Economic Performance. Cambridge, MA: Harvard University Press.

Mokyr J., Nye J. 2007. Distributional Coalitions, the Industrial Revolution, and the Origins of Economic Growth in Britain. Southern Economic Journal. 74: 50-70.

Moser P. 2005. How Do Patent Laws Influence Innovation? Evidence from Nineteenth-Century World's Fairs. American Economic Review. 95: 1214-1236.

Mousnier R. 1970. French Institutions and Society, 1610-1661. In: Cooper J. P. (ed.) The New Cambridge Modern History. Volume 4: The Decline of Spain and the Thirty Year's War. Cambridge, MA: Cambridge University Press.

Mousnier R. 1974. Les institutions de la France sous la monarchie absolue: 1598-1789. Paris: Presses Universitaires de France. 
Murphy K. M., Shleifer A., Vishny R. 1989. Industrialization and the Big Push. Journal of Political Economy. 97: 1003-1026.

Musson A. E., Robinson E. 1960. The Origins of Engineering in Lancashire. Journal of Economic History. 20: 209-233.

Musson A. E., Robinson E. 1969. Science and Technology in the Industrial Revolution. Manchester: Manchester University Press.

Nardinelli C. 1980. Child Labor and the Factory Acts. Journal of Economic History. 40: 739-755.

Ngai L. R. 2004. Barriers and the Transition to Modern Growth. Journal of Monetary Economics. 51: $1353-$ 1383.

Nicolini E. 2007. Was Malthus Right? A VAR Analysis of Economic and Demographic Interactions in Preindustrial England. European Review of Economic History. 11: 99-121.

Nordhaus W. D. 2004. Schumpeterian Profits in the American Economy: Theory and Measurement. Cowles Foundation Discussion Paper. 1457.

North D. C. 1981. Structure and Change in Economic History. New York: Norton.

North D. C. 2005. Understanding the Process of Economic Change. Princeton: Princeton University Press.

North D. C., Weingast B. 1989. Constitutions and Commitment: The Evolution of Institutions Governing Public Choice in Seventeenth-Century England. Journal of Economic History. 49: 803-832.

O’Rourke K. H., Rahman A., Taylor A. M. 2008. Luddites and the Demographic Transition. Mimeo.

Pearson R., Richardson D. 2001. Business Networking in the Industrial Revolution. Economic History Review. 54: 657-679.

Pollard S. 1964. Fixed Capital in the Industrial Revolution in Britain. Journal of Economic History. 24: 299 314.

Pollard S. 1965. The Genesis of Modern Management. London: Penguin.

Pollard S. 1981. Peaceful Conquest: The Industrialization of Europe, 1760-1970. New York: Oxford University Press.

Posner E. A. 2000. Law and Social Norms. Cambridge, MA: Harvard University Press.

Reis J. 2005. Economic Growth, Human Capital Formation and Consumption in Western Europe before 1800. In: Allen R. C., Bengtsson T., Dribe M. (eds). Living Standards in the Past: New Perspectives on Wellbeing in Asia and Europe. Oxford: Oxford University Press.

Rodrik D., Subramanian A., Trebbi F. 2004. Institutions Rule: The Primacy of Institutions over Geography and Integration in Economic Development. Journal of Economic Growth. 9: 131-165. 
Rosenthal J.-L. 1992. The Fruits of Revolution, Property Rights, Litigation and French Agriculture (17001860). New York: Cambridge University Press.

Rostow W. W. 1975. How It All Began: Origins of the Modern Economy. New York: McGraw-Hill.

Schofield R. 1973. Dimensions of Illiteracy, 1750-1850. Explorations in Economic History. 10: 437-454.

Smith A. 1966 (1776). The Wealth of Nations. New York: Augustus.

Tabellini G. 2006. Culture and Institutions: Economic Development in the Regions of Europe. Mimeo. Bocconi.

Temin P. 1997. Is it Kosher to Talk about Culture? Journal of Economic History. 57: 267-287.

Voigtländer N., Voth H.-J. 2006. Why England? Demographic Factors, Structural Change and Physical Capital Accumulation during the Industrial Revolution. Journal of Economic Growth. 11: 319-361.

Voigtländer N., Voth H.-J. 2008. The Horsemen of Growth: Plague, War and Urbanization in Early Modern Europe. Mimeo. Pompeu Fabra.

Voth H.-J. 1998. Time and Work in Eighteenth-Century London. Journal of Economic History. 58: $29-58$.

Voth H.-J. 2001a. The Longest Years: New Estimates of Labor Input in England, 1760-1830. Journal of Economic History. 61: 1065-1082.

Voth H.-J. 2001b. Time and Work in England 1750-1830. Oxford: Oxford University Press.

Voth H.-J. 2003. Living Standards during the Industrial Revolution: An Economist's Guide. American Economic Review. 93: 221-226.

Voth H.-J. 2004. Living Standards and the Urban Environment. In: Floud R., Johnson P. (eds). The Cambridge Economic History of Modern Britain. Volume 1: Industrialisation, 1700-1860. Cambridge, MA: Cambridge University Press.

Vries J. de. 1978. Barges and Capitalism: Passenger Transportation in the Dutch Economy 1632-1839. Wageningen: A. A. G. Bijdragen.

Vries J. de. 1981. Barges and Capitalism: Passenger Transportation in the Dutch Economy, 1632-1839, 2nd ed. Utrecht: HES.

Vries J. de. 1984. European Urbanization 1500-1800. Cambridge, MA: Harvard University Press.

Vries J. de. 1990. Problems in the Measurement, Description, and Analysis of Historical Urbanization. In: Woude A. van der, Hayami A., Vries J. de (eds). Urbanization in History. A Process of Dynamic Interactions. Oxford: Clarendon Press.

Vries J. de. 1994. The Industrial Revolution and the Industrious Revolution. Journal of Economic History. 54: 249-270. 
Vries J. de. 2001. Economic Growth before and after the Industrial Revolution: A Modest Proposal. In: Prak M. (ed.) Early Modern Capitalism: Economic and Social Change in Europe, 1400-1800. London: Routledge.

Vries J. de. 2003. Connecting Europe and Asia: A Quantitative Analysis of the Cape-Route Trade, 1497-1795. In: Flynn D. O., Giráldez A., Glahn R. von (eds). Global Connections and Monetary History, 1470-1800. Aldershot: Ashgate.

Vries J. de. 2008. The Industrious Revolution. Cambridge, MA: Cambridge University Press.

Vries J. de, Woude A. van der. 1997. The First Modern Economy: Success, Failure, and Perseverance of the Dutch Economy, 1500-1815. Cambridge, MA: Cambridge University Press.

Watkins S., Walle E. van de. 1985. Nutrition, Mortality, and Population Size: Malthus' Court of Last Resort. In: Rotberg R. I., Rabb T. K. (eds). Hunger and History. Cambridge, MA: Cambridge University Press.

Watkins S., Menken J. 1985. Famines in Historical Perspective. Population and Development Review. 11: 647-675.

Wells H. G. 2009 (1923). Men Like Gods. New York: Wildside Press.

Williamson J. G. 1982. The Structure of Pay in Britain, 1710-1911. Research in Economic History. 7: 1-45.

Williamson J. G. 1985. Did British Capitalism Breed Inequality? London: Allen and Unwin.

Woods R. 1989. Population Growth and Economic Change in the Eighteenth and Nineteenth Centuries. In: Mathias P., Davis J. A. (eds). The First Industrial Revolutions. Oxford: Blackwell.

Woods R. 2000. The Demography of Victorian England and Wales. New York: Cambridge University Press.

Woods R. 2003. Urban-Rural Mortality Differentials: An Unresolved Debate. Population and Development Review. 29: 29-46.

Wrigley E. A. 1983. The Growth of Population in Eighteenth-Century Britain: A Conundrum Resolved. Past and Present. 98: 121-150.

Wrigley E. A. et al. 1997. English Population History from Family Reconstitution, 1580-1837. Cambridge, MA: Cambridge University Press.

Zanden J. L. van. 1995. Tracing the Beginning of the Kuznets Curve: Western Europe during the Early Modern Period. Economic History Review. 48: 643-664.

Zanden J. L. van. 2001. Early Modern Economic Growth: A Survey of the European Economy, 1500-1800. In: Prak M. (ed.) Early Modern Capitalism Economic and Social Change in Europe, 1400-1800. London: Routledge.

Zanden J. L. van. 2005a. Cobb-Douglas in Pre-modern Europe: Simulating Early Modern Growth. IISH Working Paper. May. 
Zanden J. L. van. 2005b. Una estimacion del crecimiento económico en la edad moderna. Investigaciones de Historia Economica. 1: 9-38.

Zanden J. L. van. 2009. The Road to the Industrial Revolution: Institutions and Human Capital Formation in Europe in Global Perspective, 1000-1800. Leiden: Brill.

Zanden J. L. van, Moor T. de. 2010. Girl Power: The European Marriage Pattern and Labour Markets in the North Sea Region in the Late Medieval and Early Modern Period. Economic History Review. 63: 1-33. 


\section{М. А. Неуважаева}

\section{Институциональные условия формирования негосударственных вузов в России ${ }^{1}$}

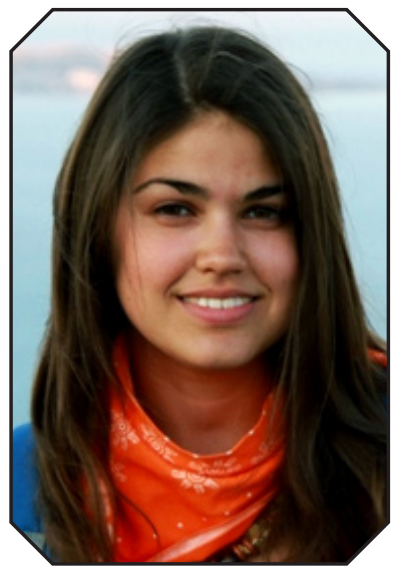

НЕУВАЖАЕВА Мария Андреевна студентка

магистратуры

«Прикладные методы социального анализа рынков» факультета социологии НИУ ВШЭ (Москва, Россия).

\section{Email:}

m.neuvazhaeva@ gmail.com
В статье представлен критический анализ прочесса формирования и развития негосударственного сектора высшего образования в России с позиции нового институционального подхода в экономической сочиологии. Выделяются условия бурного распространения негосударственных вузов в других странах, в которых их деятельность успешно дополняет (а иногда и замещает) деятельность государственных вузов. Исследования, существующие по этой теме, показывают, что негосударственный сектор привносит организачионное разнообразие, и это особенно характерно в условиях приватизачии и становления либеральной экономики. Однако на основании проведённой работы выдвинут тезис, что случай России идёт вразрез с опьтом других стран: здесь государственные и негосударственные вузы с самого начала очень тесно переплетены между собой. Это задаёт абсолютно другое видение природы российских негосударственных вузов. Данный тезис сформулирован по результатам анализа глубинных интервью с основателями и преподавателями московских негосударственных вузов, а также анкетного опроса студентов. В статье была предпринята попытка проследить структурачию поля негосударственных вузов и благодаря этому показать и объяснить институцииональный изоморфизм, который присущ негосударственному сектору высшего образования в России.

Ключевые слова: негосударственные вузы; университет; новый институциональный подход; изоморфизм; высшее образование.

«Mьл обреченьл на типичность...» Из интервью с проректором одного из негосударственных университетов

\section{Введение}

По мере перехода к рыночным отношениям доля негосударственного сектора и частного капитала возрастает и охватывает не только рынки продовольствия, материальных товаров, но и сферу услуг, куда входит и профессиональное образование. По заключению ЮНЕСКО, доля негосударственного сектора в образовании в странах с переходной экономикой тем выше, чем больше показатели экономического развития страны [Bjarnason et al. 2009]. Например, в Индонезии количество частных университетов в 100 раз превышает количество государственных.

\footnotetext{
Статья написана на основе бакалаврского диплома «Формальная структура и организационная идентичность негосударственных университетов на рынке образовательных услуг», выполненного на факультете социологии НИУ ВШЭ в 2012 г. Научный руководитель - И. В. Павлюткин, к. с. н., старший преподаватель кафедры экономической социологии.
} 
Если обратиться к мировому опыту в формировании частного сектора, то можно отметить, что он укрепился в статусе достаточно динамичного и стабильно растущего сектора третичного образования. В 1985 г. доля зачисленных студентов в учреждения частного высшего образования во всём мире составляла 18\%, тогда как на 2010 г. эта цифра выросла до 31,3\% [Levy 2010]. Однако возникновение и распространение частного высшего образования опосредовано экономическим и социальнокультурным контекстом определённой страны, что влияет и на темп, и на динамику, и на взаимоотношения частного сектора с другими институтами.

Если обратиться к опыту новой России, то первые негосударственные вузы стали появляться в 1992 г. Преобладающей тенденцией после распада Советского Союза стала идея свободы. В ситуации резкой нехватки бюджетных средств либеральные законы «Об образовании» (№ 3266-1 от 10 июля 1992 г.) и «О высшем и послевузовском профессиональном образовании» (№ 125-Ф3 от 22 августа 1996 г.) дали ректорам свободу в действиях; наметилось заметное расслоение вузов, деятельность которых прежде полностью контролировалась и финансировалась государством. Например, согласно ст. 42 закона «Об образовании» государство финансирует обучение только того количества студентов, которое соответствует контрольным цифрам, однако при этом университеты имеют право «использовать внебюджетные средства на оплату труда преподавателей» [Об образовании 1992: ст. 42]; ст. 45 и 47 разрешают оказывать платные образовательные услуги и вести предпринимательскую деятельность. Как результат, вносимая студентами, обучающимися на коммерческой основе, плата и сдача площадей в аренду составили 84\% внебюджетных ресурсов финансирования высшего образования в 1997 г. Что касается участия государственной казны в общем финансировании, то её доля составила всего 57\% [Адриан et al. 2000]. Кроме того, следует отметить и другой важный фактор общемировых изменений — тенденцию к глобализации, а значит, и усиление взаимозависимости России и других стран в разных сферах, в том числе в образовании [Schofer, Meyer 2005]. В связи с этим менялась и структура высших учебных заведений, происходило внедрение двухступенчатой модели образования, активизировалось международное сотрудничество, развивались информационные технологии и проч.

Вузы начала 1990-х гг. в России можно условно разделить на три группы. Первая группа государственных вузов предпочитала сдавать свои площади, в том числе и общежития, в аренду. Относящиеся к этой группе учреждения стали открывать приносящие прибыли экономические, управленческие, юридические специальности и, почувствовав свободу, решали подзаработать, используя государственные ресурсы. Эта тенденция прослеживалась даже в технических и естественнонаучных вузах. Вторая группа действовала по инерции. Такие вузы продолжали жить так же, как и в советское время, ничего не распродавая, ничего не приобретая. Отсутствие финансирования и амортизационных отчислений привело к плачевным последствиям для состояния материально-технической базы; доля невыплаченных долгов по коммунальным платажем в общем финансировании вузов на 1997 г. составила 13\% [Адриан et al. 2000]. Однако руководители таких вузов ничего не предпринимали, продолжая надеяться на государство. Третья группа воспользовалась свободой с пользой для себя, двинулась вперёд в своём развитии. Такие вузы начали активно искать и привлекать работодателей, сотрудничать с зарубежными университетами, открывать новые направления и формы обучения. Им было тесно в прежних рамках, они хотели стать «вузом завтрашнего дня», и их развитие напрямую зависело от личности, амбиций и влияния ректора в разных кругах.

К третьей группе вузов можно отнести и вновь появившиеся негосударственные университеты, чья история становления в 1990-е гг. во многом напоминала развитие негосударственного сектора высшего образования в дореволюционной России 2 . Их действия контролировались Министерством образования РСФСР, но инициатива создания исходила снизу; первыми студентами были преимущественно взрослые люди; открывавшиеся направления обучения отличались от приоритетных отраслевых. Кроме того, эти вузы стали активно использовать новые формы обучения - электронную и дистанцион-

2 См. подробнее: [Ильинский 2004]. 
ную, которая сделала большой шаг вперёд в своём развитии (в законодательстве эти формы обучения были прописаны лишь в феврале 2012 г. [Об образовании 2012: ст. 15]).

По данным Росстата, в 2009-2010 гг. доля негосударственных учреждений составляла 41\% общего числа вузов в стране, а обучающихся в них студентов - $17 \%$ всех студентов в России. Основываясь на данных «Мониторинга экономики образования» (МЭО) ${ }^{3}$, можно рассчитать, что плата за обучение во многих государственных университетах не сильно отличается от стоимости обучения в негосударственном вузе 4 . По результатам анализа данных МЭО за 2010 г., государственные и негосударственные вузы в большинстве своём различаются только по параметрам «источники финансирования», «отраслевая специализация», «количество учащихся» и «изменение динамики приёма учащихся за последний год».

При этом динамика изменений демографической ситуации, обострение конкуренции как внутри частного сектора, так и на рынке образовательных услуг, отсутствие финансовой поддержки со стороны государства и изменения в законодательстве, введение новых правил делают негосударственный сектор высшего образования в России крайне нестабильным и подверженным институциональным изменениям, а также общественной критике. Сейчас большинство негосударственных вузов ждёт от государства распределения бюджетных мест и финансовой поддержки. Заметим, что доходы вузов почти полностью составляет плата за обучение от студентов; по данным МЭО за 2010 г., мало кто привлекает финансы со стороны. В то же время университеты хотят операционной автономности, возможностей оказывать влияние на государственную образовательную политику и привлекать больше студентов. Но перед тем как давать негосударственным вузам свободу действий или вовсе их делегитимировать, нужно понять, зачем они создавались и что этому способствовало.

В литературе о высшем образовании выделяют три основных условия появления негосударственного сектора: (1) спрос на образование превышает предложение; (2) появляется спрос на специализированные высшие учебные заведения; (3) часть потребителей хочет получить образование более высокого качества (здесь большую роль играет статус семьи студента и элитарность вуза) [Geiger 1986; Levy 1986].

Что касается первого условия, то в ситуации, когда государственный сектор не справляется с резким ростом спроса на образование, появляется массовый частный сектор (mass private sector). Подобные вузы массового образования свойственны, скорее, развивающимся странам, где государство не успевает (из-за нехватки финансовых ресурсов, инфраструктуры) за разрастающимся средним классом, предъявляющим спрос на высшее профессиональное образование. Избыточный спрос может случиться на определённые узкие специальности, например, в сфере услуг. Такой ход развития частного сектора можно проследить на примере Бразилии и Японии.

Второе условие связано с предоставлением частными вузами самых разных видов образования, что довольно непросто сделать в государственном секторе, который нельзя назвать клиентоориентированным. Нередко различные конфессиональные и культурно-этнические группы, профессиональные со-

3 «Мониторинг экономики образования» (МЭО) проводится с 2002 г. НИУ ВШЭ с целью информационной поддержки образовательной политики, обеспечения органов управления образованием России актуальной информацией об экономическом положении системы образования, формирования информационной базы, необходимой для анализа и прогноза развития сферы образования; подробнее о проекте см.: URL: http://memo.hse.ru/

4 Средняя минимальная стоимость обучения в государственном вузе на очном отделении (бакалавриат, специалист) не отличается от средней минимальной в негосударственном: соответственно 44368 руб. за семестр против 42107 руб. за семестр. Однако средние максимальные показатели статистически различны: 70925 руб. в государственном вузе против 55744 руб. в негосударственном. Данная информация основана на расчетах по базе данных МЭО (опрос руководителей) за 2010 г. 
общества, продвигая свои интересы и идеологию, создают собственные специализированные высшие учебные заведения. Примеры Бельгии и Нидерландов доказывают, что влиятельные религиозные общины способны самостоятельно основать вуз, образование в котором для определённого контингента населения будет более приемлемым, чем в любом государственном вузе. Кроме того, эти общины сумели добиться относительно равноценного финансирования со стороны государства: стипендий, субсидий, грантов и проч.

Третья немаловажная предпосылка появления негосударственных университетов - это спрос на более качественное образование в более благоприятных условиях (порой «лучшее для лучших»). Как это возможно? Одной из причин, вероятно, стала идея получения академической степени для личного блага, в котором заинтересован непосредственно сам индивид, чтобы позже извлекать выгоду для самого себя, а не в интересах общества [Altbach 1999]. Высокообеспеченные родители предпочитают для своих детей частные вузы, которые могут обеспечить высокое качество образования, индивидуальный подход, особую организационную культуру (что обычно называется «дух университета»), лучших преподавателей, оригинальную программу курсов, безопасность и проч. Кроме того, немаловажным является состав студентов с точки зрения их социального происхождения. Подобные университеты готовят выпускников для высоких карьерных позиций. Но возможен и другой вариант, когда способные и умные абитуриенты просто не проходят по конкурсу в престижный государственный университет (примеры Франции, Японии).

Относительно российской действительности нельзя сказать однозначно, что вышеперечисленные условия повлияли на возникновение негосударственного сектора. Вообще, в западной литературе к негосударственным университетам применяют термин private, то есть «частный», связанный с личной собственностью, отдельным хозяйствованием, принадлежащий отдельному лицу, но не государству. Чаще всего такой университет старается реализовать собственную модель поведения на рынке, внутреннюю организационную структуру. Учреждения такого типа состоят в соответствующих общественноэкономических отношениях с государством и другими организациями. К российской действительности больше подходит понятие не «частный» вуз, а «негосударственный» (non-state, non-government). Tакие вузы хотя и не финансируются центральным правительством, но значительно полагаются на поддержку и ресурсы от других государственных организаций и учреждений. Часто их связь с органами государственной власти и государственными университетами гораздо ближе, чем может показаться.

В России два сектора высшего образования не являются комплементарными, как в опыте других стран; они также и не сосуществуют параллельно. Государственные и негосударственные вузы находятся в очень тесном переплетении. Именно поддержка государственных вузов и наличие других институциональных условий (о которых будет сказано ниже) подтолкнули многих предприимчивых людей открыть негосударственные учреждения, развивать их по одному и тому же принципу, а не в разных направлениях (тем самым делая высшее образование более разнообразным), что обычно свойственно частным университетам в результате разгосударствления и технически рациональной конкуренции [Levy 1999; 2004].

Цель данной статьи - выявить особенности структурации поля негосударственных университетов и на этой основе показать и объяснить институциональный изоморфизм, который свойствен негосударственному сектору высшего образования в России и по сей день. Мы также сделаем попытку разобраться в природе изоморфизма и разнообразия учебных учреждений и представим методологию проведённого исследования с описанием трудностей, с которыми пришлось столкнуться в ходе составления выборки. Кроме того, нам предстоит ответить на ряд вопросов, в том числе на следующие: чем вызвано появление негосударственных вузов в России в начале 1990-х гг.? Какие цели преследовали основатели вузов и первые сотрудники? Что за механизмы оказали (и продолжают оказывать) столь 
сильное влияние на переплетение деятельности государственного сектора с негосударственным? Почему студенты идут учиться в негосударственные вузы?

\section{Отправная точка - новый институциональный подход}

В этой работе негосударственные вузы рассматриваются с точки зрения нового институционализма в социологии организаций [Meyer, Rowan 1977; DiMaggio, Powell 1983; Scott, Meyer 1983; Meyer, Rowan 2006], в рамках которого высшее образование представляется открытой системой, где существование организации зависит от состояния окружающей среды [Scott 1998]. Вероятно, кто-то сочтёт, что современное высшее образование - это, скорее, рынок. Мы вполне согласны с этим утверждением, так как в последние десятилетия благодаря экономической социологии произошли изменения в интерпретации рынка в качестве места, где взаимодействуют индивиды или группы индивидов (фирмы, организации) для обмена, основывающегося на купле-продаже товара; теперь рынок осмыслен как социально укоренённая форма хозяйства и встроен во множество социокультурных, политических, исторических, сетевых контекстов (см. работы Н. Флигстина, М. Аболафия, М. Грановеттера, В. Зелизер, К. Поланьи и др.). Выстраивание и дальнейшее развитие рынка в России сопряжено с политикой государства, появлением новых институтов, а также с влиянием тех многообразных, противоречивых логик «строителей», то есть организаций и отдельных индивидов, имеющих свои представления о том, как должен функционировать рынок. Находясь в одном организационном поле, университеты, студенты, абитуриенты, Министерство образования и науки РФ взаимодействуют между собой, определяя поведение друг друга, поддерживая выработанные концепции контроля и паттерны сотрудничества.

Филипп Селзник предположил, что любая организация на пути формирования института проходит через социализацию, с течением времени обретая свои ценности, нормы, отличительные характеристики, практики поведения [Selznick 1957]. При этом Селзник особое внимание уделяет конкурирующим ценностям, а также властным позициям. Однако позже мысль Селзника получила развитие, и было высказано предположение о том, что на формирование организации также оказывает влияние её институциональное окружение, институциональная среда [DiMaggio, Powell 1983]. Именно среда вынуждает организацию меняться, если та хочет получить и когнитивную, и социополитическую легитимацию. Новый институциональный подход как раз и интересует процесс изменения организации для соответствия своей институциональной среде.

Что касается образовательных учреждений, то они в наибольшей степени ориентируются не на эффективность, не на содержательный результат, а на соответствие институциональной среде [Scott 1991; Павлюткин 2010]. Теория нового институционализма концентрирует своё внимание на гомогенности (однородности) в процедурах, методах, структурах, которые проявляются со временем у организаций, находящихся в одном поле деятельности. Именно это и является результатом их институционального поведения: следуя институциональным правилам в своих действиях, организации всё больше становятся похожими друг на друга. Димаджио и Пауэлл выделяют три механизма институциональных изоморфных изменений в зависимости от внешнего давления: (1) принудительный изоморфизм (coercive isomorphism) проявляется при давлении со стороны государства или же более крупных международных договорных обязательств; (2) подражательный изоморфизм (mimetic isomorphism) можно наблюдать при неопределённости и неоднозначности в постановке целей организации; (3) нормативный изорфизм (normative isomorphism) вызван требованиями к сотрудникам в профессиональной области, а также образуемыми ими деловыми связями [DiMaggio, Powell 1983].

Для того чтобы лучше понимать процессы, происходящие в российских университетах, в частности среди негосударственных вузов, попробуем рассмотреть эти механизмы с позиции гомогенизации непосредственно в среде высшего образования в целом. 
Первый из них — принудительный изоморфизм - отражает влияние и формальных, и неформальных предписаний государства, а также включённость государства (или отдельных университетов) в международное профессиональное сообщество. Что касается включённости, то национальные образовательные системы в самых разных точках мира имеют очень много общего, потому что они всё больше зависят от мировых стандартов. Болонский процесс, международные рейтинги университетов, международные ассоциации и конференции, ориентация на университеты мирового класса и многое другое превращают университет в глобальный институт [Meyer et al. 2007] с устоявшимися образцами, традициями и подходами. Такому развитию событий предшествовала история изоморфизма университетов. Например, было проведено исследование в семи западных странах, которое показало распространение одинаковых практик в системе образования [Windolf 1997]. Кроме того, захват и освоение многих территорий при колонизации в XIX-XX веках способствовали распространению западной системы образования в Индии, Африке и др. [Schofer, Meyer 2005]. Таким образом, происходит институционализация, рационализация и стандартизация системы высшего образования для достижения коллективных целей [Meyer, Boli, Thomas 1994]. Университеты также стараются соответствовать институциональной среде, стремятся к получению высших баллов в рейтингах, привлекают специалистов из Всемирного банка, ЮНЕСКО, Организации экономического сотрудничества и развития (ОЭСР) и др. для создания лучшего университета, для приглашения на работу лучших преподавателей и исследователей, для отбора лучших абитуриентов.

Если говорить о необходимости соответствовать правилам, устанавленным государством, то наиболее значимые рычаги регулирования деятельности вузов - это аккредитация, лицензирование, количество выделяемых бюджетных мест. Университеты, чтобы иметь право на существование, стараются соответствовать единым нормам, организуют свои учебные планы, читаемые курсы, научную деятельность по единым стандартам. В данном случае государство как третья сторона и меньшее из зол в сравнении с самими государственными и негосударственными вузами может устанавливать механизмы контроля, права собственности и структуру управления для всех образовательных учреждений, обеспечивая стабильные и надёжные условия существования образовательной системы.

Отдельно отметим, что политика государственного контроля задаёт характер взаимоотношений между государственными и негосударственными вузами. Существует несколько типов контроля, которые разительно отличаются друг от друга в зависимости от страны [Altbach 1999]. Например, в Южной Корее доля негосударственного сектора доходит до 80\% на рынке образовательных услуг, но при этом государство применяет очень строгий контроль над его действиями. В странах же Западной Европы традиционно преобладает доля государственных университетов, и немногочисленные негосударственные вузы либо имеют (как было отмечено выше) религиозную направленность, либо предоставляют специальное бизнес-образование. Что касается стран Восточной Европы (стран бывшего соцлагеря) и России, то мгновенный рост частных вузов здесь связан с формированием рыночной экономики, но при этом нельзя утверждать, что они вытесняют государственные учреждения высшего образования.

Однако выстраиваемые государством правила игры, как замечает Флигстин, не могут удовлетворять интересы всех участников, и при любом раскладе они будут действовать в пользу определённых игроков - университетов [Флигстин 2003]. Гейгер рассматривал различные возможные конфигурации частных и государственных учреждений в одной образовательной системе в зависимости от институциональных условий, формируемых государством. Автор отмечает, что количество и типы государственных вузов напрямую влияют на положение негосударственных университетов в каждой отдельно взятой стране. Ему удалось выделить следующие три конфигурации [Geiger 1986]:

1. Частный массовый сектор с ограниченным государственным сектором. Такая конфигурация свойственна странам, где существует всего несколько небольших государственных учреждений с высоким качеством образования (например, в Японии). Проблему избыточного спроса на 
высшее образование в таком случае решают множество частных университетов. Они в основном обучают большинство населения (преимущественно из низких социально-экономических слоёв), не столь избирательны при наборе, у них невысокая плата за обучение, а также эти университеты не отличаются именитыми преподавателями или высокими местами в национальных рейтингах. Деятельность (развитие инфраструктуры, научная деятельность, материальная база и т. п.) частных вузов во многом зависит от платы за обучение. Государство почти не оказывает никакой материальной или финансовой помощи в развитии частного сектора. Кроме того, чтобы избежать проблемы слишком некачественного образования, государство вводит стандарты, контролирующие и регулирующие образовательные программы, а также определённые условия для аккредитации и получения государственной лицензии.

2. Параллельно сосуществующие государственный и частный секторы. Гейгер выделяет три условия для такой конфигурации: (1) наличие определённых групп людей, чьи интересы лоббируют в правительстве; (2) единый высокий стандарт для национальных государственных университетов; (3) большой объём государственных субсидий на поддержку частного сектора. Таким образом, достигается равный доступ к образованию для групп людей (например, для протестантских групп) с разными социальными характеристиками, при этом все могут получить хорошее по качеству образование. Разумеется, для частного сектора есть вероятность некоторой потери автономии, свободы развития, самобытности. Тем не менее в Бельгии и Чили частные вузы являются полноценными конкурентами государственных вузов.

3. Почти монолитная система государственного высшего образования с частным сектором на периферии. Система государственной поддержки высшего образования направлена только на государственные вузы, вследствие чего вузы частного сектора могут рассчитывать лишь на самих себя. Негосударственные вузы Великобритании, Швеции, Франции, как правило, сосредоточены на определённой нише студентов (многие из которых являются важными спонсорами), что делает их особенно чувствительными к изменениям в потребностях таких студентов.

В результате можно наблюдать, как в зависимости от логики контроля государства и его правил игры выстраиваются отношения между участниками образовательного рынка. Помимо возможных конфигураций частного и государственного образования немаловажной остаётся проблема политики правительства в отношении частных вузов. В разных странах поддержка студентов, выплата налогов (по льготной схеме), включённость руководства вуза в обсуждение и решение проблем в высшем образовании на государственном уровне, лоббирование интересов частного сектора и др. происходят неодинаково. Однако все эти институциональные условия влияют на размер частного сектора, степень его развитости, а также на стабильность.

Уильям Зумета в своих исследованиях выделил три возможных типа государственной политики по отношению к негосударственным вузам [Zumeta 1992].

Первый тип - невмешательство (laissez-faire) - подразумевает игнорирование государством развития частного сектора, который не получает ни льгот, ни стипендии для студентов, ни любой другой финансовой поддержки. Процесс регулирования частных вузов ограничивается лишь их лицензированием, при этом они не могут участвовать в формировании государственной образовательной политики. Как результат, частный сектор представлен небольшим количеством учебных заведений и предлагает невысокое качество образования, узкопрофильные курсы, недостаточную оснащённость материальнотехнической базы.

Второй тип - централизованное планирование (central-planning), при котором и государственные, и негосударственные вузы представляют интерес для правительства и финансово поддерживаются в 
равной степени из одной казны. Частные вузы ввиду этого менее склонны разнообразить подходы в образовании, менее гибки и не столь быстро реагируют на изменения на рынке образовательных услуг, обучают, по словам Зумета, не более 10-20\% общего числа студентов. Тем не менее благодаря своим собственным источникам дохода и государственной поддержке, частные вузы успешно конкурируют с государственными. Они могут тратить больше денег на собственное развитие, на развитие отдельных вузовских направлений.

При третьем типе - рынок конкуренции (market-competitive) - государство создаёт все условия для открытой рыночной конкуренции между самыми разнообразными образовательными учреждениями, стимулирует у них дух соперничества, собирая сравнительную характеристику и данные об эффективности вузов (вероятно, составляет рейтинги). О наибольшей успешности вуза свидетельствует наибольшее количество студентов. Кроме того, и государственный, и частный вузы довольно автономны в вопросах академического развития. Как результат, государственный вуз, как и частный, порой тоже оказывается в ситуации зависимости от внешних обстоятельств, от нестабильности на рынке, а потому должен быть гибким, динамичным и активным, чтобы привлекать умных студентов, высокопрофессиональный педагогический состав и проч.

Представленные типы не всегда совпадают с жизненными реалиями. В данном эмпирическом исследовании ниже будет представлена другая модель как государственного регулирования, так и взаимоотношений государственного и негосударственного секторов высшего образования в России, опосредованных институциональной средой.

Рассмотрим второй механизм институциональных изоморфных изменений - процесс подражательного изоморфизма [DiMaggio, Powell 1983]. Когда на устоявшемся рынке чётко определены сильные и слабые, а также крупные и мелкие участники, успешно подстраиваемые под институциональные условия и не совсем, то те, кто находится в менее выигрышном положении, пытаются перенимать практики более успешных организаций в этой среде. Кроме того, подражание присуще и тем, кто находится в ситуации неопределённости. Издержки минимизируются, если университет выберет уже зарекомендовавшую себя модель развития, а не будет выстраивать нечто новое, с бо́льшими рисками. Примером могут служить планы развития некоторых университетов в России (преимущественно федеральных - Дальневосточный, Уральский, Сибирский), в чьих официальных текстах заложена одна и та же стратегия на ближайшее десятилетие. Именно она уже успешно реализуется в нескольких ведущих университетах. У нас есть предположение, что в России частный сектор с каждым годом всё больше начинает походить на государственный, используя его инструменты, так как считает государственные университеты более успешными на рынке образовательных услуг.

Третий механизм - нормативное давление - основывается на профессионализации работников. Во-первых, важную роль играет состав персонала: от претендентов на схожие позиции в разных университетах ждут одного и того же набора знаний, компетенций. Во-вторых, в сфере образования постоянно создаются различные ассоциации, проводятся конференции, встречи, семинары, которые являются площадкой для взаимодействия сотрудников, обмена опытом и, конечно, развития профессиональных сетей. Что касается самих университетов, то их «организационный престиж и ресурсы - ключевые факторы привлечения профессионалов» [Димаджио, Пауэлл 2010: 45], а значит, они пытаются создать те же условия для работы преподавателей и исследователей, что и их конкуренты. Эти предположения легли в основу одной из гипотез нашего исследования, задача которого - рассмотреть специфику преподавательского и административного состава в негосударственном университете, а также рекрутирования. Почему люди в начале 1990-х гг. приходили работать в организацию нового типа — в негосударственный вуз? Вероятно, ни организационный престиж, ни ресурсы не могли играть в этом случае решающую роль. 


\section{Иная точка зрения на организационное разнообразие}

В академическом сообществе можно встретить иную точку зрения на природу негосударственных университетов. Американский исследователь Даниэль Леви, автор многочисленных исследований, говорит о том, что изоморфизм больше свойствен государственному сектору, нежели частному [Levy 1999; 2004]. В отличие от Димаджио и Пауэлла, Леви критикует принципы нового институционализма, показывая ограниченность изоморфных сил при объяснении небывалого роста частного высшего образования, и связывает рост частного сектора с изменениями в политической экономии, которые с течением времени ослабляют влияние государства и других институтов на развитие частных университетов [Levy 2004]. Таким образом, изменения дают университетам возможность взять на себя ответственность и принять риски, чтобы трансформировать имеющееся устройство вуза, начать активно реагировать на внешние и внутренние институциональные условия. Леви считает, что рост частного сектора привносит межорганизационное разнообразие, которое требует объяснения и тесно связано с «технически рациональной конкуренцией» (technically rational competitive forces) [Levy 2004: 18], доминирующей над организационной рациональностью [DiMaggio, Powell 1983].

Леви и его коллеги провели много исследований в разных странах (Китай, Венгрия, Аргентина, Чили, Новая Зеландия, Доминиканская Республика, Грузия, Индия, Турция и др. $)^{5}$, сравнивая данные о частных высших учебных заведениях с принципами нового институционализма. Одно из положений, например, касается интернационализации со стороны международных организаций и ассоциаций. Их цель состоит не только в сравнении и ранжировании университетов или же в выдвижении требований странам, которым они оказывают поддержку; они также стимулируют институциональную конкуренцию, финансовую диверсификацию в организациях [Levy 2004]. Однако если присмотреться, то акторы высшего образования живут и мыслят в рамках образовательной системы своей страны, а не в рамках международной системы.

Что касается гипотезы Димаджио и Пауэлла о зависимости организаций от одних и тех же ресурсов, то в исследованиях Леви и его коллег приводятся примеры того, как используются конституционные запреты (или же ограничения) против государственного субсидирования частных учреждений. Таким образом, частные университеты специально ограничивают свою зависимость от государства, привлекая общественные организации, негосударственные фонды, частные компании. Например, в Китае можно отметить значительные пожертвования университетам от китайцев, переехавших за рубеж, или же от членов деловых кругов [Peterson et al. 2001].

Государство порой косвенным способом может влиять на разнообразие в сфере высшего образования, утверждает Леви, имея при этом в виду падение статуса государственных университетов в национальной системе образования, когда государство не повышает их легитимность в обществе, не занимается их продвижением и развитием [Levy 2004], тогда как частные университеты активизируются и начинают выстраивать свою социополитическую легитимацию за счёт связей с бизнесом, политическими и церковными структурами. В качестве примера можно привести университеты, описанные в книге Бёртона Кларка «Создание предпринимательских университетов»: Стратклайд (Шотландия), Чалмерс (Швеция) [Кларк 2011b].

В литературе встречаются и другие примеры исследований, подтверждающих тезис о том, что институциональные условия не всегда приводят к изоморфному поведению организаций; встречается и обратное, о чем свидетельствуют некоторые эмпирические работы. Например, при исследовании частных колледжей в США в 1971-1986 гг. предполагалось, что под действием внешних институциональных изменений произойдут перемены в учебных планах, в результате чего они во многом станут похожи

5 См. подробнее: Working Papers of PROPHE (The Program of Research in Private Higher Education). URL: http://www. albany.edu/dept/eaps/prophe/working_papers.html 
друг на друга [Kraatz, Zajac 1996]. Однако на протяжении 15 лет ничего не изменилось. Ещё одно исследование изучало эффекты от нововведений правительства в отношении образовательных учреждений (планирование, ориентированное на достижение результатов (result-oriented planning), было новой системой управления, введённой правительством Норвегии для всех типов учреждений, в том числе и образовательных). Это исследование показало, что не нововведения повлияли на изменения в университетах, а отдельные авторитетные акторы и их интересы [Larsen, Gornitzka 1995].

Таким образом, нами был представлен критический обзор литературы в сфере высшего образования, где были проанализированы факторы, характеризующие отношения между институциональной средой и университетом (в частности, негосударственным), среди которых интернационализация высшего образования, механизмы изоморфного поведения, конфигурации государственных и негосударственных университетов в зависимости от политики государства, а также примеры организационного разнообразия. Университеты относятся к такому типу организаций, которые особенно чувствительны к внешним институциональным изменениям. Их цели, стратегии находятся под влиянием поведения внешних акторов, в роли которых могут выступать профессиональные сообщества, государство, другие университеты, рынок труда, мировое сообщество. Порождает ли это влияние схожие по многим параметрам негосударственные вузы или же привносит организационное разнообразие? Для российской действительности этот вопрос остаётся открытым. Задачей данной статьи является не только установить, что присуще негосударственному сектору — изоморфизм или разнообразие, но и проанализировать и понять, почему, как и в каких условиях произошло тесное переплетение негосударственного сектора высшего образования с государственным.

\section{Закрытость негосударственного сектора: проблема отказов 6}

В любом социологическом исследовании при обсуждении методологии камнем преткновения становится вопрос валидности и репрезентативности. В России почти не проводились качественные исследования негосударственных вузов. Большая часть информации, которой мы располагаем, имеет количественный характер.

Тем не менее за основу был взят качественный опрос, так как он позволяет проанализировать труднодоступные взаимодействия, влияние институциональных условий и даёт возможность почувствовать жизнь внутри самого университета, не просто пронаблюдать действия руководителей и преподавателей, а понять, какой смысл они вкладывают в свои каждодневные практики, как интерпретируют происходящее с университетом. Это особенно важно в исследовании негосударственных вузов России, потому что здесь в основном проводятся количественные исследования с целью реформирования системы высшего образования, определения «хороших» и «плохих» вузов, выделения каких-либо субсидий, контроля качества и проч. [Заборова 2002; Довейко 2011; Алайба 2004]. Однако что кроется за цифрами, рейтингами, стратегическими планами развитий? Порой мы довольно ограничены в своих знаниях о системе негосударственного высшего образования, примеряя на него трафарет государственного и отбрасывая всё, что не вписывается в эти рамки. Однако при этом мы упускаем из виду все те мелочи, которые в итоге приводят к изменениям всей системы. Как заметил Бёртон Кларк, один из ведущих исследователей высшего образования, перефразируя известное изречение и используя его по отношению к качественным методам (в частности, к кейс-стади), «истина — в мелочах» [Кларк 2011а: 19].

Тем не менее искомая мелочь находится под семью замками. По ходу составления выборки и достижения договорённостей с рядом университетов мы столкнулись с проблемой, которая отчасти определила набор кейсов, - отказы от участия в опросе. Следует заметить, что университеты более охотно соглашались на серию интервью, узнав, что исследование социологическое, а не журналистское, независимое, не носит коммерческий или иной другой заказной характер.

6 Эмпирический материал был собран автором. 
Однако количество отказов всё же было очень большим. Некоторые вузы отказывались прямо по телефону (иногда не в очень вежливой форме). Другие просили прислать на имя ректора письмо с примерным списком вопросов интервью, но потом долго не давали положительного ответа, и в результате связь с этими вузами обрывалась. О таком поведении (неразглашение каких-либо данных) говорилось и в предыдущих исследованиях негосударственного сектора ${ }^{7}$. Таким образом, приходилось использовать личные связи для установления контактов, ссылаться на Высшую школу экономики.

Каковы же причины отказов? О первой причине, опираясь на проведённые интервью и общение с представителями вузов по телефону, можно сказать, что учредители или ректорат либо президент не готовы раскрывать информацию финансового характера, какие-либо результаты внутреннего мониторинга (хотя, как показали интервью, они их и не проводят). Негосударственный вуз так или иначе представляет собой коммерческое предприятие. Как и любое другое предприятие, негосударственный университет не видит для себя пользы в том, чтобы делиться своей информацией с другими. Однако исследование не подразумевало выявления количественных показателей, нам интереснее было узнать мнения руководителей и (или) учредителей по ряду других вопросов.

Вторая причина - боязнь «чёрного пиара» ${ }^{8}$, как объяснили руководители вузов. Полевой этап исследования пришёлся на конец марта — начало апреля, то есть время активной рекламной кампании многих университетов, проведения Дней открытых дверей и проч. В течение многих лет СМИ печатают статьи, занижающие позиции негосударственных вузов или отдельных университетов. Как выяснилось в ходе опроса, негосударственные вузы независимо от размера очень чувствительны к любой оценке их деятельности со стороны. Соответственно, опасаясь негативной информации, вузы предпочитают ни с кем не идти на контакт.

Третья причина отказов - занятость ректоров и других руководителей. Порой нужно было получать разрешения об опросе других руководителей вуза у ректора, который долгое время был в отъезде, а все решения о подобных мероприятиях проходили только через него.

Один из вузов согласился на участие, но при этом «тщательно подготовился» к приходу интервьюера. Во-первых, интервьюера встретил специально обученный человек, который сразу определил формат беседы: без диктофона, все другие звукозаписывающие устройства отключить. Во-вторых, ректором был определён список людей, у которых можно было взять интервью. Когда интервьюер просил связать его с преподавателями с большим стажем работы, то ему косвенно давали понять, что это невозможно. Кроме того, сами респонденты были явно подготовлены к встрече и к вопросам (примерные вопросы высылались заранее). На некоторые вопросы сразу отвечать отказывались, так как «политика руководства этого не позволяет».

\section{Эмпирическая база исследования}

И всё же нам удалось добиться согласия на участие в исследовании от трёх московских университетов ${ }^{9}$, которые являются довольно типичными вузами, открывшимися в начале 1990-х гг., с факультетами экономико-менеджериальной направленности, с сопоставимыми ценами на образовательные

7 При проведении исследования «Качество платного приёма в вузы РФ - 2011» (НИУ ВШЭ совместно с Общественной палатой и РИА Новости) лишь 10\% всей выборки руководителей негосударственных вузов согласились заполнить анкету. Проблема отказов также была зафиксирована в проекте «Мониторинг экономики образования» НИУ ВШЭ.

8 Буквально накануне отбора вузов, 12 февраля 2012 г., на телеканале «Россия 1», в программе «Вести недели», прошел репортаж «Тьма знаний», где далеко не в лучшем свете были представлены Московский финансово-промышленный университет «Синергия» и некоторые другие вузы.

9 Для участия в исследовании рассматривались только московские вузы, так как, по официальным данным, Москва территория с наибольшим количеством негосударственных высших учебных заведений в России, к тому же многие из них имеют широкую сеть филиалов по всей стране [Павлюткин, Андрущак, Новиков 2010]. 
услуги, имеющими очную форму обучения. В целях сохранения конфиденциальности при описании результатов исследования названия вузов кодировались (вуз № 1, вуз № 2, вуз № 3).

В качестве методов опроса были выбраны глубинное интервью, а также анкетный опрос студентов. В каждом вузе были проведены четыре-пять интервью с руководителями (ректорами, проректорами), а также с преподавателями, которые работают в университете с момента образования. Всего были взяты 14 интервью. Практически все респонденты до настоящего вуза работали ещё в двух-четырёх негосударственных, а также государственных учреждениях высшего образования. Иногда истории одного вуза предшествовали истории других негосударственных вузов. Можно сказать, что многие одни и те же особенности учебного и административного процессов встречаются в разных негосударственных вузах Москвы. Тем не менее малая представленность вузов в интервью накладывает ограничения на возможности распространения полученных нами результатов.

Кроме качественного опроса, был проведён анкетный опрос студентов в выделенных негосударственных вузах. Анкета была разработана для студентов 1-5-х курсов обучения. Этот количественный инструмент предоставил возможность понять ценности и установки студентов негосударственного вуза, которые, в свою очередь, дополнили материал из интервью ${ }^{10}$. Подобный инструмент лежит в основе Индекса характеристик колледжа (College Characteristic Index), в котором студенты оценивают различные утверждения относительно их жизни в высших учебных заведениях: учебный план, преподавание и аудиторную активность, правила и регламенты, внеучебную активность и проч. [Pace, Robert 1962]. Эта методология открыта для сопоставления данных с другими университетами и воспроизводима в других институциональных условиях.

Всего были опрошены 177 студентов (их социально-демографические характеристики представлены в приложении). Для проведения анкетного опроса была определена квотная выборка 5\% студентов очной формы обучения в каждом вузе. Значимыми критериями выступали: место обучения (г. Москва); курс обучения (1-5-е курсы, то есть 2012-2016 годы окончания обучения); форма обучения (очная) ${ }^{11}$.

\section{Основные результаты исследования}

\section{Негосударственный вуз: создание новой модели или способ адаптации?}

Может показаться, что в начале 1990-х государство не могло справиться с резко возросшим спросом на высшее образование, что и послужило толчком к развитию негосударственного сектора. Однако мы полагаем, что негосударственный сектор в России образовался не из-за спроса, а из-за предложения.

Согласно опросу представителей негосударственного сектора, одним из основных событий, повлиявших на создание негосударственного вуза, было расформирование в начале 1990-х гг. оборонной промышленности, армии, НИИ и конструкторских бюро. Хорошо, если уволенных специалистов перехватывали небольшие частные фирмы, но большинство из них, не успев начать деятельность, разваливались. Таким образом, многие люди оставались без работы, с семьями, которые нужно было содер-

10 В ходе акетирования мы задавали вопросы о ценностях студентов, об их планах на будущее, но в данной статье внимание больше уделено причинам выбора негосударственного вуза студентом, а именно ответу на вопрос: «Чем порождается спрос на высшее образование в негосударственных учреждениях?».

11 Опрос студентов изначально планировалось проводить в университетах с бумажной версией анкеты. Были попытки достичь договорённости с администрацией университетов о санкционировании опроса и об организации проведения. Однако возникала вероятность того, что после проведения опроса руководство сочтёт полученные данные непригодными для анализа в данном исследовании (предпочтёт оставить у себя), поэтому мы выбрали онлайн-опрос студентов без привлечения администрации вузов (персональная рассылка сообщений о предложении принять участие в исследовании в социальных сетях и на электронные почтовые ящики групп). 
жать $^{12}$. Все по-разному пытались приспособиться к новым социально-экономическим реалиям. Однако полученные ранее специальности были невостребованными или же малооплачиваемыми.

Решением проблем стали неформальные экономические практики (см.: [Щербакова 2006; Заславская 1995; Климова 2006]), например челночный бизнес, которым стали заниматься работники и физического труда, и умственного; или же организация частных курсов по профессиональной переподготовке специалистов. Новых «предпринимателей» можно было подразделить на вынужденных (для них бизнес представлял собой способ заработка, выживания в новых условиях) и добровольных (для которых бизнес был самоцелью, возможностью - ранее недоступной - реализовать себя). Первый (вынужденный) тип превалировал (см.: [Щербакова 2006]). Наиболее важными критериями успеха на тот момент считались человеческий капитал и социальный. Их положительное сочетание нередко материализовалось в создание нового типа образовательного учреждения - негосударственного вуза. Для одних это была отличная возможность обеспечить работой и достатком себя и знакомых, для других — шанс заняться собственным делом (особенно если человек прежде работал в сфере образования). И даже спустя 20 лет, говоря о негосударственных вузах, респонденты не только рассматривают их в качестве места для получения высшего образования, но и соглашаются с тем, что вуз — «это бизнес, но бизнес особого характера, так как имеет дело с особым товаром - знаниями» ${ }^{13}$.

Анализ интервью позволяет разделить учредителей в начале 1990-х гг. такого рода бизнеса на две категории: учредитель-владелец и учредитель-ректор. Именно их отношение к новому делу задавало стиль образовательному учреждению.

Первый тип (учредитель-владелец) может и не иметь отношения к образовательной среде, но при этом владеть несколькими небольшими вузами, во главе которых он обязательно ставит или родственников, или давнего(-юю) проверенного(-ую) знакомого(-ую). Кроме того, владельцами могут быть сразу несколько человек. Именно они определяют политику вуза. Общение со студентами, преподавателями происходит через ректора - своего рода менеджера, который сам не может распоряжаться имуществом, ставками заработных плат, но готовит вуз к аккредитации, ведёт бухгалтерские процедуры, по согласованию с учредителем вводит новые формы и программы обучения. Как сказал один из респон-

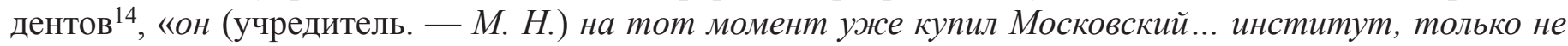
знал, что с ним делать, потому что сам он в высшей школе никогда не работал». Учредитель покупает (продаёт, арендует) площади, закрывает институт или перепродаёт в случае его нерентабельности. Имя учредителя-владельца в речи респондентов не соотносится с происходящим внутри университета.

Второй тип (учредитель-ректор) - люди, работающие в университете, занимающие административные должности, а порой и преподающие. Они не владеют сетью институтов, а концентрируются на

12 «Почти 20 лет работала в оборонке (разные КБ, которые занимались оборонной промышленностью)... Потом оборонка стала как-то разваливаться...Год 1985 ... Предложили очень хорошую фирму образовать. Сказали, что будет фирма, тоже связанная с космосом... Обещали хорошие зарплаты. Но потом эта фирма деньги отмывала» (женщина, ректор, вуз № 1).

«Вообще-то я по образованию технолог... Всю жизнь я проработала в научно-исследовательских институтах, лабораториях ...Но наступили времена застоя, 70-е годы, уже никому ничего не надо. Все разработки “в стол”, потом перестройка. Всё с молотка пошло, хотя у нас оборудование всегда было, мы с выставки привозили... Работы как таковой не было, зарплаты не было, а у меня ребёнок на руках, больная мама, кормить надо было. Сначала переманили в одну южнокорейскую фирму, потом она быстро закрылась, тогда это тоже было типично» (женщина, проректор, вуз № 1).

13 Из интервью с мужчиной, руководителем филиалов, вуз № 2.

14 Из интервью с женщиной, проректором, вуз № 1. 
развитии одного ${ }^{15}$. Важными характеристиками такого руководителя являются место получения образования и прежние места работы, что непосредственно влияет на модель университета, политику управления вузом и подбор привлекаемых преподавателей. Изначально учредители-ректоры набирают себе команду (как администраторов, так и преподавателей), основываясь на предыдущем профессиональном опыте общения и рекомендациях друзей. Их личные и профессиональные связи помогают также в прохождении аккредитации, лоббировании своих интересов (например, в Ассоциации негосударственных вузов), установлении новых контактов с представителями других организаций. Чаще всего они активно вовлечены в деятельность своего университета, напрямую взаимодействуют со студентами и с преподавателями. Как выразился один из респондентов: «Проректор, ректор вуза - как лётчик: если он не будет летать, он перестанет понимать тех, кто летает» ${ }^{16}$. Учредитель-ректор является представителем вуза на всех мероприятиях и защищает его интересы в средствах массовой информации, на политических собраниях. Иначе говоря, изначальное отношение учредителей к своему вузу значительно повлияло на дальнейшую стратегию развития университета.

Как было сказано выше, негосударственный вуз стал ковчегом для многих специалистов в ситуации неопределённости и фактической безработицы. Новая система принуждала расстаться (полностью или частично) с полученной прежде специальностью. Принцип рекрутирования администраторов в негосударственные вузы хорошо это иллюстрирует. В основном административные должности занимали работники, далёкие от учебного процесса, которые находились в поиске какой-либо приемлемой работы. Через знакомых они узнавали о свободных вакансиях и приходили на собеседования. Их тут же сажали или в приёмную комиссию (состоящую из одного-двух человек), или на место проректора по учебной деятельности. Тогда принимали студентов по факту оплаты, поэтому как таковых вступительных экзаменов не было. Люди военных, технических, конструкторских специальностей, программисты самостоятельно изучали законодательство, процедуры заполнения документов, составления учебных планов. От их производительности зависело, останутся они работать в институте или нет.

«А я вообще никогда в этой системе не работала, я не знаю, что это такое... Мне рассказали самые азы и бросили. И вот уже в прочессе мне надо было набираться этого опыта, мало того, плату за обучение тоже на меня повесили» (женщина, проректор, вуз № 1).

Мысли о свободе и новых возможностях в развитии негосударственного сектора высшего образования сосуществовали с соображениями о выживании. Причём о выживании не только специалистов оборонной промышленности или различных НИИ, но также и государственных университетов. По словам респондентов, в государственных вузах на тот момент была сложная ситуация с финансированием, зарплата сотрудников не соответствовала среднему уровню жизни, накапливались долги за неуплату по коммунальным платежам, почти не было средств на поддержание в надлежащем состоянии материально-технической базы. Эти результаты также подтверждают выводы, представленные в исследованиях Дмитрия Суспицына [Suspitsin 2005] и авторов «Белой книги российского образования» [Адриан et al. 2000].

Настоящим спасением от бедственного положения государственных университетов стало создание негосударственных вузов. Именно им сдавались в аренду площади, учебные классы, разрешалось пользоваться библиотеками, столовыми, спортивными сооружениями на взаимовыгодных условиях. Кроме того, преподавателям государственных вузов позволяли работать по совместительству в негосударственных. Такая практика была свойственна не только региональным вузам (что, кстати, спо-

15 «Руководители университета живут университетом. У ректора рабочий день начинается в восемь, заканчивается после девяти... Например, он участвует в различных конференциях, он участвует в собраниях, он участвует в экспертных советах, он участвует в политической жизни... Руководство, проректоры — это те люди, которые всё своё время отдают университету. У нас почти все проректоры ведут занятия» (мужчина, проректор, вуз № 3).

16

Из интервью с мужчиной, проректором, вуз № 3. 
собствовало быстрому развитию филиальной сети негосударственных вузов) или небольшим столичным, но также и ведущим - МГИМО, МГУ им. М. В. Ломоносова, Академии народного хозяйства им. Г. В. Плеханова, РАН ${ }^{17}$. Этот этап формирования негосударственных вузов явился своеобразным фундаментом для обоюдного взаимодействия негосударственного сектора с государственным: одни получали площади и сотрудников, что было необходимо для развития, другие - доход от аренды, к тому же можно было не беспокоиться за судьбы преподавателей (многие из них и до сих пор продолжают совмещать занятость в государственных и негосударственных вузах). При этом для создания негосударственного вуза требовались лишь небольшие денежные затраты.

«Чтобы организовать институт в 90-х годах, нужен был какой-то уставный капитал. Какие-то смешнье деньги вносишь, регистрируешь и создаёшь институт» (женщина, проректор, вуз № 1).

«Откуда у нас был финансовый капитал? Нет. Они (государственные вузы. - М. Н.) давали в своё время и площзади для размещения нас там. В Финансовой академии мы находились какое-то время, и оттуда же брали соответственно и преподавательский коллектив... Ректоры этих вузов нормально относились к работе их в негосударственном секторе» (мужчина, проректор, вуз № 3).

Если говорить о распространённом в то время совместительстве преподавателей, то существовали и второстепенные причины этого явления. Кроме необходимости выживать, следует отметить, что опрошенные руководители и преподаватели стремились к самореализации - к претворению в жизнь собственных проектов, чтению дополнительных курсов (которые и оплачивались дополнительно) помимо обязательных. Преподавателей привлекали перспективы развития, а также потенциал — новые возможности, динамика.

Интервьюер: Вам была интереснее эта работа, чем та (в государственном вузе. - М. Н.)?

Респондент: Конечно, зарплата сыграла роль. Потом сыграло роль то, что ты более свободен, и интересно было... Здесь очень много проектов (женщина, проректор, вуз № 3).

Однако, как признался один из респондентов, за науку как не платили, так и не платят, поэтому в основном все работали и работают как преподаватели. Тем не менее стабильность позиции преподавателя полностью зависела и зависит от него самого: если в государственном вузе человек в случае чего может рассчитывать на отдачу от своего статуса, стажа работы, то в опрошенных негосударственных вузах контракты заключаются на один год, при неудовлетворённости работой преподавателя ему тут же сокращают нагрузку, уменьшают ставку или его увольняют ${ }^{18}$.

Кроме этого, причиной совместительства была и реализация карьерных задач. В любом государственном учреждении существет сложившаяся за десятилетия должностная иерархия, в которой не так просто занять высокую должность, тем более сделать это быстро. В новой же структуре негосударственного вуза многие места руководителей, деканов, проректоров были вакантны, и преподаватель при договорённости с учредителем (а личные связи играли немалую роль) — мог сразу удовлетворить свои амбиции, получив руководящую должность. Однако далеко не все покидали государственные

17 О практике тесного взаимодействия между государственными и негосударственными вузами см. также: [Suspitsin 2005].

18 В одном из обследованных нами университетов существует довольна жёсткая система ежегодной аттестации преподавателей, к которой заранее готовятся, если хотят продления контракта. Информант не стал говорить, какие конкретные критерии входят в оценивание, он лишь отметил особую значимость трудовой дисциплины (без опозданий (задержек), своевременная подача всей необходимой документации). 
университеты, потому что чувствовали, что коммерческий сектор только развивался, а, как выразился один из респондентов, «государственный университет - это было стабильно, это было понятно» (женщина, проректор, вуз № 3). Кроме того, многолетнее чувство привязанности к прежнему месту работу тоже было немаловажным фактором для предпочтения совместительства увольнению из государственного вуза.

Что касается направлений, по которым осуществлялась (и продолжает осуществляться) деятельность негосударственных вузов, то это менеджериальные, экономические, управленческие и юридические специальности. На вопрос: «Почему именно эти специальности?» — все респонденты давали похожий ответ:

«Чтобы попасть в технический вуз, человек должен был иметь техническую базу, лаборатории нужны. А что такое гуманитарный вуз, почему они как грибы вырастали? У тебя есть стол - и всё, больше ничего для этого не нужно. Читают лекиии, никаких лабораторных занятий, ничего нет» (женщина, проректор, вуз № 1).

«Просто в тот момент на рынке самые эффективные были именно гуманитарные специальности, по рентабельности. Затраты минимальные: лекиии и профессорско-преподавательский состав, никаких лабораторий специальных, кроме юридчческих, там криминалистическая лаборатория должна быть, а цена на рынке очень высокая: экономисты, юристы - очень выгодно» (мужчина, проректор, вуз № 3).

Рентабельность и быстрая окупаемость стали главными критериями при открытии направлений обучения в негосударственных вузах. Особенно в условиях, когда государственные вузы сдавали площади в аренду и сами только начинали запуск этих же специальностей. Позже стали появляться курсы по информационным технологиям, туризму, гостиничному сервису, лингвистике, бизнесу. Однако их открытию предшествуют длительные переговоры, расчёты инвестиций.

Таким образом, можно сказать, что специфика создания негосударственного университета заключается не в попытке создания новой формы, а в адаптации к новым правилам и условиям, предоставляемым государственным сектором, в ситуации выживания.

\section{Лицензирование и аккредитация}

Аккредитация - это наиболее значимое событие в жизни любого негосударственного учреждения. Как только вуз утвердили на бумаге, он получает от государства первичную лицензию на оказание образовательных услуг, затем вторичную, и после этого выдаётся документ об аккредитации сроком действия сразу на пять лет, по истечении которых руководство вуза снова должно обратиться в Рособрнадзор за продлением. Вуз без аккредитации, с одной лишь лицензией, не может выдавать дипломы государственного образца, предоставлять отсрочку от армии.

Если вуз нацелен на получение аккредитации, то его программы должны соответствовать государственным стандартам. Этот критерий задаёт очень жёсткую рамку всей системе. Дело в том, что аккредитация учебных заведений не определяет позицию учреждения по отношению к государству: абсолютно все вузы в стране (и государственные, и негосударственные) должны соответствовать нормам, установленным Рособрнадзором. Стереотипное представление о некачественности образования, полученного в негосударственном вузе, в отличие от полученного в государственном, не соответствует истине, если оба типа вуза имеют аккредитацию. Низкое качество может с той же вероятностью встречаться и в государственных высших учебных заведениях. 
Кроме того, следует различать аккредитацию вуза как такового и аккредитацию его учебных программ. При оценке вуза внимание уделяют подбору кадров, условиям для обучения, материально-технической оснащённости зданий, первому выпуску. При оценке образовательных программ эксперты проверяют качество знаний студентов. Вуз может иметь лицензию, аккредитацию, но при этом не иметь аккредитации нескольких направлений.

Таким образом, негосударственный университет может вводить свои авторские курсы, открывать новые направления, но ущерб будут нести студенты этих отделений, чей будущий диплом не будет никем признан. С одной стороны, подобная «уравниловка» по заданному набору критериев позволяет поддерживать определённое качество образования (независимо от правового статуса вуза), не даёт возможности слабым вузам вырабатывать свои стандарты, которые априори будут хуже государственных; но с другой - нивелирует конкурентную борьбу между вузами в отношении реализуемых учебных программ. Соответственно уничтожается и разнообразие учебных моделей, организационных структур, которые теоретически могут встроить негосударственные вузы в национальную образовательную систему.

Ориентация идёт не на студента или абитуриента (какие программы, авторские курсы, дополнительные предметы ему интересны?), а на внимание и оценку Министерства образования и Рособрнадзора, поэтому, например, наём преподавателей с готовыми методическими материалами из государственных вузов значительно снижает издержки негосударственных вузов - стандарты ведь одни и те же. На вопрос, заданный руководителям негосударственных вузов о том, отличаются ли хоть чем-нибудь их курсы и методы преподавания от модели в государственных вузах, ответ был однозначным:

Интервьюер: А образовательные программы?..

Респондент: Всё по стандартам. Ни шага вправо, ни шага влево (женщина, проректор, вуз № 1).

«Нет особых, ярких программ. У нас есть яркие преподаватели, которые читают яркие авторские курсы, и это хоть как-то расивечивает унылое однообразие обязательных для всех программ» (мужчина, проректор, вуз № 3).

Наиболее предприимчивые вузы всё же не замыкаются на государственных стандартах и претворяют в жизнь дополнительные программы, научные семинары, творческие курсы, которые делают их отличными от других вузов. В этом случае инициатива преподавателя и поддержка ректора являются основополагающими, и если человек и (или) вуз хочет реализовываться за пределами государственных стандартов, он будет это делать независимо от того, в каком вузе он работает - государственном или негосударственном.

\section{Студенты негосударственного вуза: критерии выбора и оценка условий}

По словам опрошенных руководителей вузов, первыми студентами негосударственных учреждений были по большей части взрослые люди, которые шли за получением второго высшего образования. Особой популярностью пользовались программы дистанционного и заочного обучения, ввиду чего некоторые вузы осуществляли только такую деятельность. Вузы с очной формой обучения привлекали новых абитуриентов рекламными проспектами и удобным, «близким к дому», месторасположением, что позволило набирать на первый курс молодёжь из соседних районов.

Важно отметить, что негосударственные вузы не испытывали особых проблем с наполняемостью групп. Наоборот, очень много людей были готовы заплатить деньги для получения высшего образования. В 1970-1980-е гг. молодые люди, не поступившие в государственные университеты или неуспеш- 
но сдавшие сессию, шли в техникумы (сейчас переименованные в колледжи). Это была самая низкая ступень профессионального образования. Однако с появлением возможности получения платного высшего образования многие абитуриенты уже не хотели идти в техникум. Таким образом, спрос был: негосударственные вузы нашли свою аудиторию. Но каковы критерии отбора вуза? Выбирают ли абитуриенты между государственным и негосударственным университетами? На основе анкетного опроса были замерены ценностные установки студентов, определены причины выбора вуза, а также удалось их глазами взглянуть на процесс обучения в негосударственном университете ${ }^{19}$.

\section{Причины выбора негосударственного вуза}

Для изучения причин, которые повлияли на выбор студентом вуза, респондентам были предложены 12 факторов, из которых нужно было выбрать не более трёх самых значимых:

1. территориальное расположение;

2. стоимость обучения;

3. профессионализм преподавателей, сильный педагогический состав;

4. рекомендации друзей, знакомых;

5. активная студенческая жизнь;

6. активная научная жизнь;

7. высокий уровень знаний, образования, подготовки, качественное образование;

8. престиж, авторитет, высокий рейтинг, хорошая репутация вуза;

9. хорошие перспективы для личностного роста, развития, возможность самореализации;

10. наличие интересующей специальности;

11. возможность успешного трудоустройства после окончания вуза;

12. низкий проходной балл.

Ответы распределились так, как показано на рисунке 1.

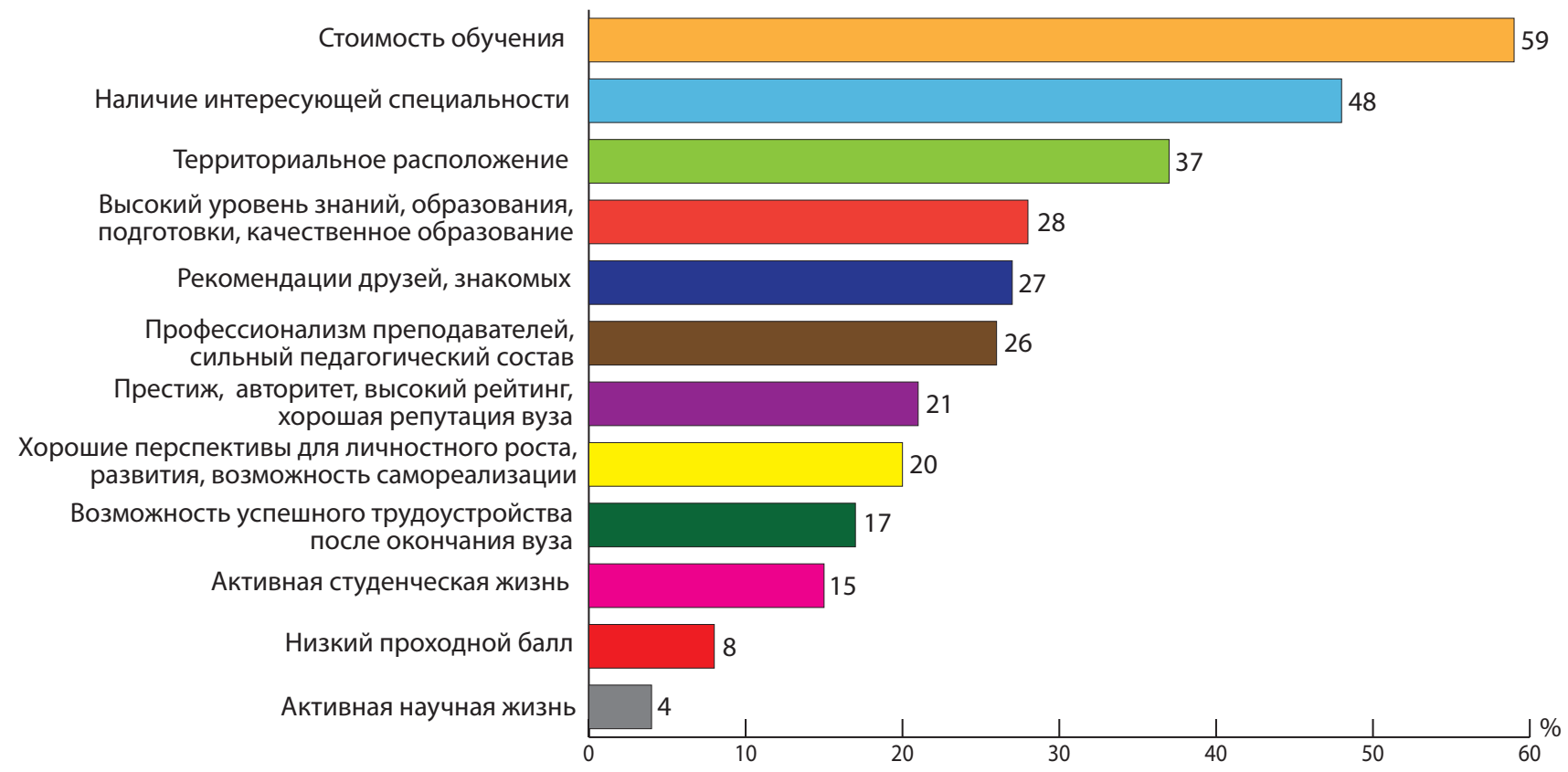

Рис. 1. Распределение ответов студентов негосударственных вузов на вопрос: «Что для Вас было наиболее значимым при выборе вуза, где Вы сейчас учитесь?»

19 Мы осознаём всю ограниченность нашего опроса, наши данные смещены и не являются репрезентативными для всей совокупности студентов негосударственных вузов. Тем не менее, сравнивая полученные данные с данными Мониторинга студенческой жизни НИУ ВШЭ за 2009 г., можно выдвинуть предположение, что заметных различий в ценностях студентов государственных и негосударственных вузов нет. Однако эта гипотеза требует более глубокого анализа. 
На первом месте расположились факторы «стоимость обучения» $(59 \%)$ и «наличие интересующей специальности» (48\%). Важно отметить, что негосударственные вузы не могут обеспечить качественный отбор абитуриентов, так как студент лучше там, где есть набор на бюджетные места. Вступительные экзамены, определяющие уровень знаний абитуриентов, являются неким ситом, которое оставляет лучших и не пропускает слабо подготовленных. Этот инструмент работает во многих государственных вузах, куда стремятся умные ребята, желающие учиться на бюджетной основе. Негосударственный вуз, не имеющий мест, финансируемых государством, берёт к себе тех, кто приходит и готов платить. Мониторинг качества приёма в вузы ${ }^{20}$ в 2011 г. выявил, что средний балл зачисленных по результатам ЕГЭ в государственные вузы составил 63,4 (участвовали 492 учреждения из 524), тогда как средний балл в негосударственные вузы - 54 (участвовали 45 учреждений из 428). Тем не менее следует отметить, что впервые в 2012 г. государство выделило бюджетные места 54 негосударственным вузам по всей России, что составило 10\% всех выделенных бюджетных мест (при этом в конкурсе участвовали 85 негосударственных вузов) $)^{21}$.

Некоторые вузы (те, что могут себе это позволить) устанавливают собственные минимальные баллы ЕГЭ и даже открывают бюджетные места за счёт университета, но многие другие проводят зачисление в студенты по факту оплаты, ориентируясь лишь на минимальные баллы, установленные государством. Таким образом, как сказал один из руководителей вуза, «самыле лучшие пройдут в самые лучшие вузы ... и правильно сделают, потому что нельзя сравнивать научную школу, статус, атмосферу. Конечно, лучше идти в вуз, который имеет длительную традицию и статус. Это нормально» (мужчина, проректор, вуз № 3). Негосударственные вузы по-прежнему берут не самых лучших или тех, кто боится конкуренции при приёме в государственный институт. Вот поэтому основной контингент студентов из опрошенных негосударственных вузов в первую очередь смотрит на наличие интересующей их специальности и на цену обучения. Отметим при этом, что качество обучения является менее важной характеристикой, чем его цена ${ }^{22}$.

Большинство московских семей (90\%), где есть дети, говорят о важности получения высшего образования [Петренко, Галицкая, Шмерлина 2010]. Но тогда у нас возникают вопросы: почему главным критерием отбора вуза является стоимость обучения? Каким образом стоимость определяет спрос на высшее образование? При проведении седьмой волны МЭО (2008-2009 гг.) исследователи задались вопросом о влиянии образовательного статуса семьи на стратегию выпускника школы. Результаты показали, что образовательный уровень семьи очень сильно влияет на будущее ребёнка. Так, например, в высокообразованных семьях $84 \%$ родителей хотят, чтобы их ребёнок учился в университете, тогда как в семьях со средним общим образованием лишь $37 \%$ родителей хотят направить ребёнка в вуз [Петренко, Галицкая, Шмерлина 2010]. Что касается ситуации с выбором вуза по стоимости обучения, то у нас есть следующее предположение: независимым фактором в этом случае является также образование родителей. Если у родителей нет культуры образования, если в своё время они не учились в высших учебных заведениях, то, скорее всего, при выборе вуза для своих детей они будут реагировать на простые стимулы: стоимость, территориальное расположение вуза. Вероятно, негосударственные вузы в России имеют большой спрос среди группы студентов из невысокообразованных семей. В нашем исследовании эта гипотеза не подтвердилась, тем не менее мы думаем, что целесообразно проверить её ещё раз, но на более широкой выборке, которая также будет репрезентировать регионы, поскольку цены на обучение в столице значительно выше.

20 См.: Мониторинг качества приёма в вузы - 2011. Выполнен НИУ ВШЭ и РИА Новости в рамках совместного проекта «Общественный контроль за процедурами приёма в вузы как условие обеспечения равного доступа к образованию» по заказу Общественной палаты России. URL: http://www.hse.ru/ege/second_section2012

21 См. данные на официальном сайте Министерства образования и науки РФ. URL: http://минобрнауки.рф/новости/2298

22 Стоимость обучения в негосударственном вузе меньше по сравнению со стоимостью в государственном на коммерческом отделении; см. подробнее сн. 4. 
Следует добавить, что при выборе вуза практически все студенты рассматривали государственные столичные университеты. Наиболее популярные среди них включены в рисунок 2 (названия часто упоминаемых студентами вузов выделены размером и жирностью шрифта). Распределение ответов, представленное на рисунке 2, ещё раз подтверждает тот факт, что изначально абитуриенты стремятся на бюджетные места в государственный вуз, но, не пройдя по конкурсу, останавливают свой выбор на негосударственном (обращая внимание в первую очередь на стоимость обучения).

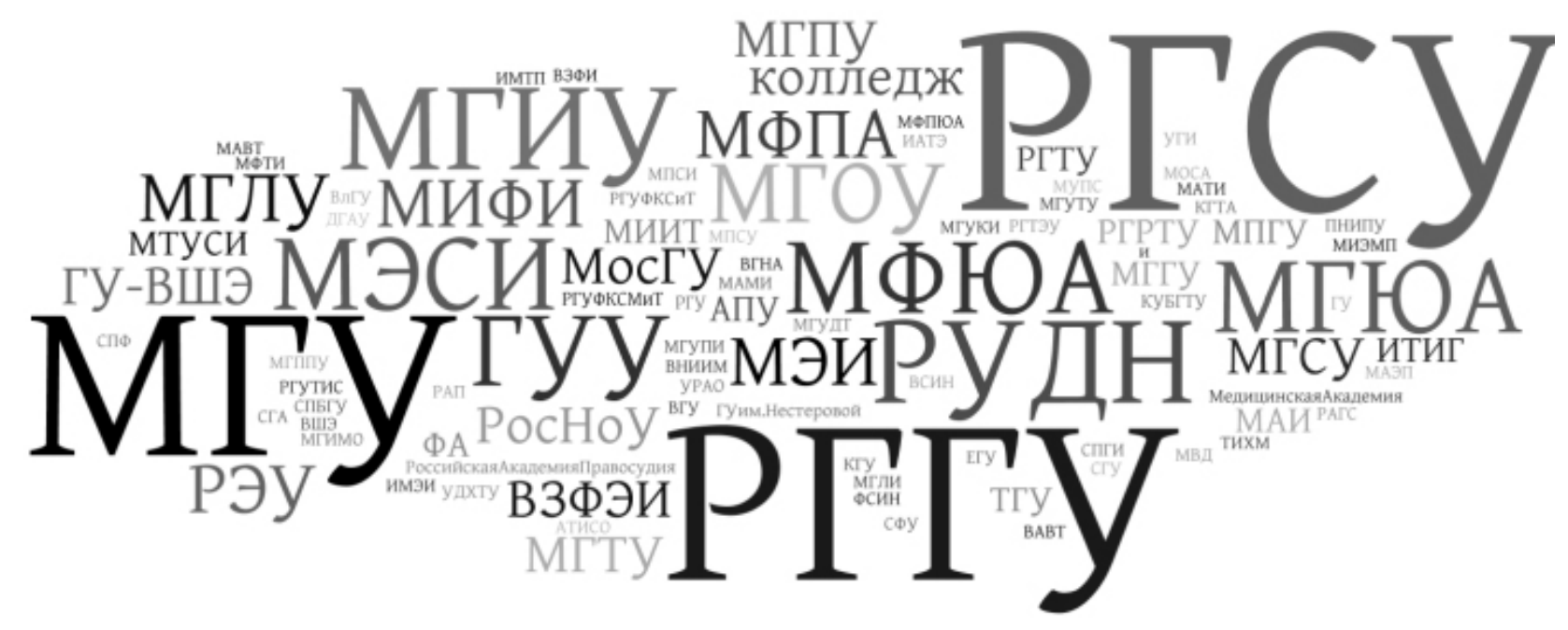

Примечание. Расшифровка названий вузов:

ГУУ - Государственный университет управления;

МГИУ - Московский государственный индустриальный университет;

МГОУ - Московский государственный открытый университет им. В. С. Черномырдина;

МГУ - Московский государственный университет им. М. В. Ломоносова;

МГЮА - Московская государственная юридическая академия;

МИФИ - Национальный исследовательский ядерный университет «МИФИ» (Московский инженерно-физический институт);

МФЮА - Московская финансово-юридическая академия (негосударственный вуз);

МЭСИ - Московский государственный университет экономики, статистики и информатики;

РГГУ — Российский государственный гуманитарный университет;

РГСУ - Российский государственный социальный университет;

РУДН — Российский университет дружбы народов.

Рис. 2. Распределение ответов студентов на вопрос:

«Какие другие вузы Вы рассматривали при поступлении?»

Следующие три места разделили факторы «территориальное расположение» (37\%), «высокий уровень знаний, образования, подготовки» (28\%), а также «рекомендации друзей и знакомых» (27\%) (см. рис. 1). Респонденты не раз говорили о том, что сетевой капитал играет значительную роль в негосударственном вузе. Это касается и студентов, и «миграции» преподавателей. Как отмечают руководители, реклама в СМИ, скидочные купоны, интернет-порталы не дают такого отклика среди абитуриентов, как «сарафанное радио»: советы дают не только друзья друзей, но и сёстры, братья, дети выпускников и сотрудников. Факторы самореализации, успешного трудоустройства, перспектив научной деятельности отходят на второй план при выборе вуза.

\section{Оценка условий обучения студентами}

Студентам предлагалось оценить условия обучения и качество преподавания в их негосударственном вузе. В целом учащиеся положительно оценивают работу преподавателей, считают, что педагоги предъявляют высокие требования к объёму самостоятельной подготовки, при этом стараются разъяснить принципы и правила подготовки качественных докладов, исследований. Преподаватели также заинтересованы в процессе обучения и стараются привлечь как можно больше студентов к работе на семинарских занятиях. Кроме того, по мнению студентов, для преподавателей в целом характерно, что они обсуждают со слушателями специфику выбранной профессии и перспективы трудоустройства. 
Если говорить о профессиональной коммуникации между преподавателем и студентом, то в большинстве случаев студент получает отклик и комментарии по проделанной им работе в ходе освоения курса (68,1\%). Тем не менее больше половины студентов почти никогда не обсуждают с преподавателем во внеаудиторное время свои идеи, мысли, соображения и не задают вопросы по поводу пройденного материала (53,5\%). Вероятно, такая немалая цифра обусловлена тем, что многие ребята параллельно учёбе работают (51\%), а значит, они больше нацелены на получение советов, рекомендаций или же, наоборот, остаются после занятий, чтобы закрыть задолженности, пропуски и проч. Однако этот вопрос требует более детального изучения.

Кроме того, студентам был задан вопрос о том, какие аспекты обучения являются наиболее характерными для их вуза. В качестве главных они выделили приобретение прикладных умений и навыков в процессе обучения, возможность работать во время учёбы, развлекательные мероприятия (концерты, фестивали, конкурсы), неформальное общение и студенческие вечеринки, а также творческое развитие студентов. Наименее важными составляющими в студенческой жизни являются участие в научноисследовательской деятельности вуза (6\%) и обучение в зарубежном вузе $(7 \%)$. Можно сказать, что студенты рассматривают вуз как место для приобретения конкретных практических навыков, знаний, и связей, которые в дальнейшем им помогут в карьере. Отметим, что больше половины опрошенных студентов работают (51\%), а ещё 36\% имеют непостоянный заработок и планируют начать совмещать работу и учёбу. Кроме того, в пожеланиях руководству вузов студенты нередко просили снизить требования, прощать задолженности и т. п., аргументируя это тем, что они работают. Это говорит о том, что у большинства студентов на первом месте всё же стоит работа, на втором — образование.

Таким образом, одним из основных отличий студентов государственного вуза от студентов негосударственного является то, что вторые не проходят какого-либо серьёзного отбора при зачислении, и соответственно этим шансом стремятся воспользоваться те, кто по разным причинам не прошёл на бюджетное место в государственный вуз. В этом случае решающим фактором выбора вуза становится стоимость обучения, а не состав преподавателей или же перспективы личностного роста. Что касается учебного процесса, то, вероятнее всего, образовательные программы в государственных и негосударственных вузах совпадают, при этом отношение преподавателя-совместителя к своей работе вряд ли будет меняться в зависимости от типа университета.

\section{Заключение}

Подводя итоги вышеизложенного, можно сказать, что, несмотря на идею свободы, на возможности экспериментирования и освоения новых образовательных практик, инициативы «снизу» (а не Министерства образования, то есть «сверху») по созданию университетов, негосударственные вузы в начале 1990-х гг. в России в большинстве своём являлись продуктом взаимодействия предприимчивых учредителей и государственных вузов ${ }^{23}$. Это важно понимать при сопоставлении российского опыта развития негосударственного сектора с его развитием за рубежом, в основе которого находятся автономность негосударственных вузов, их стремление быть независимыми, иные принципы кадровой политики и подходы в предоставлении образовательных услуг.

В России иная ситуация: не спрос на частное высшее образование вызвал предложение, а наоборот. Новая социально-экономическая ситуация, нестабильность, неудовлетворённость материальным положением в начале 1990-х гг. в какой-то степени вынудили людей заняться созданием негосударственных университетов, поэтому одной из главных целей основателей было не только привнесение чего-то

23 Разумеется, в каждом случае есть исключения. Например, такие вузы, как Российская экономическая школа (РЭШ), Московская высшая школа социальных и экономических наук (МВШСЭН), Европейский университет в Санкт-Петербурге $(\mathrm{EУ),} \mathrm{и} \mathrm{некоторые} \mathrm{другие} \mathrm{не} \mathrm{вписываются} \mathrm{в} \mathrm{настоящую} \mathrm{логику} \mathrm{изложения.} \mathrm{Их} \mathrm{практики} \mathrm{и} \mathrm{история} \mathrm{становления} \mathrm{требу-}$ ют отдельного изучения. Мы же пока опираемся на данные о трёх изученных, а также о семи-девяти негосударственных вузах, о работе в которых рассказывали респонденты. 
нового в образовательный процесс, но и обеспечение рабочими местами себя и своих знакомых, и, конечно, заработок.

Изначальная тесная связь между государственными и негосударственными вузами сохраняется до сих пор. Анализ данных указал на то, что негосударственным университетам действительно свойственно изоморфное поведение как внутри сектора, так и по отношению к государственным вузам. Таким образом, по результата нашего исследования можно определить основные механизмы, способствующие такому изоморфному поведению: это, во-первых, борьба за одни и те же ресурсы (бюджетные места, субсидии), которые предоставляет государство тем и другим; во-вторых, ограниченное число преподавателей: по ряду причин многие совмещают деятельность в государственных и негосударственных вузах; в-третьих, единое для государственных и негосударственных вузов законодательство, накладывающее ограничения на учебные программы и академическую деятельность; в-четвёртых, общая инфраструктура, так как многие негосударственные вузы, даже имея собственные здания в Москве, продолжают арендовать спортивные комплексы государственных университетов, типографии, общежития.

Кроме того, по результатам количественного опроса студентов и по данным Росстата, можно сказать, что спрос на обучение в негосударственном вузе будет существовать до тех пор, пока первостепенными причинами выбора являются стоимость обучения, наличие специальности и территориальное расположение вуза. Ввиду этого у нас возникают вопросы об идентичности негосударственного сектора высшего образования: есть ли в деятельности негосударственных вузов то, что отличает их и делает исключительными в системе высшего образования? Какие функции они выполняют? Какую ценность в себе несут? Надеемся, эти вопросы тоже не останутся без ответов.

Если обратиться к руководителям негосударственных университетов, то они не особо сопротивляются своей зависимости от государственных вузов. Да, они хотят получить больше свободы в реализуемых программах, формах обучения, но при этом почти не проявляют какой-либо активности, не ищут альтернативных источников дохода, не ставят профессиональных менеджеров в управление вузами. Что касается контрактов на аренду спортивных залов, найма преподавателей с готовыми методическими материалами из государственных вузов, то эти практики значительно снижают издержки негосударственных вузов. Также руководители негосударственных вузов требуют от государства выделения бюджетных мест, что делает их ещё более связанными с государственными университетами в борьбе за один и тот же ресурс, предоставляемый центральной властью.

Организационный изоморфизм в поведении негосударственных университетов стал чем-то наподобие входного билета, выдаваемого государством, который позволяет вписаться в систему высшего образования. Большой наплыв студентов из техникумов, повышенный спрос на дешёвое высшее образование, низкозатратные специальности, готовый на дополнительный заработок штат преподавателей, невысокие барьеры входа на рынок - всё это способствовало быстрому увеличению численности вузов, которые моделировались по одному и тому же типу, а именно по типу уже устоявшихся государственных университетов. В результате негосударственный сектор в России не привнёс какого-либо разнообразия в национальное высшее образование. При этом, когда в связи с негосударственным сектором ведутся разговоры о низком качестве образования, теневом бизнесе, нужно отчётливо понимать, что этот сектор был порождён (и продолжает существовать) под влиянием государственных структур и тех правил игры, которые эти структуры устанавливают.

Будет ошибкой не признать значение нескольких динамично развивающихся негосударственных университетов, которые стараются быть на шаг впереди остальных, не боятся рисковать, делать ошибки, но при этом принимать самостоятельные решения, не ожидая субсидий от государства или внесения поправок в законодательство. Но это уже другая история. 
Социально-демографические характеристики студентов

Приложение трёх негосударственных вузов

Таблииа П1

Распределение ответов студентов на вопрос:

«В каком университете Вы учитесь?»

\begin{tabular}{lcc}
\hline Вуз & $\mathrm{N}$ & $\%$ \\
\hline Вуз № 1 & 23 & 13,0 \\
Вуз № 2 & 67 & 37,9 \\
Вуз № 3 & 87 & 49,1 \\
Всего & 177 & 100,0 \\
\hline
\end{tabular}

Таблийа П2

Распределение ответов студентов на вопрос:

«На каком курсе Вы учитесь?»

\begin{tabular}{|c|c|c|}
\hline Курс обучения & $\mathrm{N}$ & $\%$ \\
\hline 1-й & 24 & 13,6 \\
\hline 2-й & 32 & 18,0 \\
\hline 3-й & 29 & 16,4 \\
\hline 4-й & 45 & 25,4 \\
\hline 5-й & 47 & 26,6 \\
\hline Всего & 177 & 100,0 \\
\hline
\end{tabular}

Таблиияа П3

Распределение ответов студентов на вопрос:

«Где Вы проживаете в настоящий момент?»

\begin{tabular}{lcc}
\hline «Где Вы проживаете в настоящий момент?» & $\mathrm{N}$ & $\%$ \\
\hline В общежитии & 11 & 6,7 \\
С родителями & 117 & 71,3 \\
В своей квартире/частном доме & 30 & 18,3 \\
У друзей, знакомых, родственников & 6 & 3,7 \\
Всего & 164 & 100,0 \\
\hline
\end{tabular}

Таблица П4

Распределение ответов студентов на вопрос: «Ваш пол?»

\begin{tabular}{lll}
\hline Пол & $\mathrm{N}$ & $\%$ \\
\hline Мужской & 54 & 30,5 \\
Женский & 123 & 69,5 \\
Всего & 177 & 100,0 \\
\hline
\end{tabular}




\section{Распределение ответов студентов на вопрос:}

«Скажите, за счёт каких источников дохода Вы в основном живёте?»

\begin{tabular}{lcc}
\hline «Скажите, за счёт каких источников дохода Вы в основном живёте?» & $\mathrm{N}$ & $\%$ \\
\hline Меня полностью содержат родители (родственники) & 45 & 26,8 \\
В основном за счёт родителей (родственников) и ещё подрабатываю & 40 & 23,8 \\
Я работаю и живу в основном на заработанные деньги, но иногда мне помогают & 57 & 33,9 \\
родители (родственники) & & \\
Я работаю и живу только на самостоятельно заработанные деньги & 26 & 15,5 \\
Всего & 168 & 100,0 \\
\hline
\end{tabular}

Образование матери (мачехи)

\begin{tabular}{lcc}
\hline Образование матери (мачехи) & $\mathrm{N}$ & $\%$ \\
\hline Не получила среднего образования & 1 & 0,6 \\
Среднее или неоконченное высшее & 75 & 42,4 \\
Высшее образование & 93 & 52,5 \\
Высшее образование и учёная степень & 6 & 3,4 \\
Затрудняюсь ответить & 2 & 1,1 \\
Всего & 177 & 100,0 \\
\hline
\end{tabular}

Образование отца (отчима)

\begin{tabular}{lcc}
\hline Образование отца (отчима) & $\mathrm{N}$ & $\%$ \\
\hline Среднее или неоконченное высшее & 77 & 45,3 \\
Высшее образование & 73 & 42,9 \\
Высшее образование и учёная степень & 8 & 4,7 \\
Затрудняюсь ответить & 12 & 7,1 \\
Всего & 170 & 100,0 \\
\hline
\end{tabular}

\section{Статистика ответа на вопрос: «Сколько Вам полных лет?»}

\begin{tabular}{lc}
\hline $\mathrm{N}$ & 175 \\
\hline Среднее & 20,66 \\
Минимум & 17,00 \\
Максимум & 27,00 \\
\hline
\end{tabular}




\section{Литература}

Аболафия М. 2003. Рынки как культуры: этнографический подход. Экономическая соииология. 4 (2): 63-72. URL: http://ecsoc.hse.ru/data/388/588/1234/ecsoc_t4_n2.pdf

Адриан Ж. et al. 2000. Белая книга российского образования. М.: ТАСИС.

Алайба T. et al. 2004. Студенты об имидже государственных и негосударственных вузов. Социологические исследования. 2: 93-98.

Заборова Е. 2002. Конкурентные преимущества: сравнительный анализ государственных и негосударственных вузов. Университетское управление. 4 (23). URL: http://ecsocman.hse.ru/text/17379171. html

Димаджио П., Пауэлл У. 2010. Новый взгляд на «железную клетку»: институциональный изоморфизм и коллективная рациональность в организационных полях. Экономическая социология. 11 (1): 34 56. URL: http://ecsoc.hse.ru/issues/2010-11-1/index.html

Заславская Т. И. 1995. Бизнес-слой российского общества: сущность, структура, статус. Социологические исследования. 3: 3-12.

Ильинский И. М. 2004. Негосударственные вузы России: опыт самоидентификаџии. М.: Издательство МосГУ.

Кларк Б. 2011а. Поддержание изменений в университетах. Преемственность кейс-стади и кониепичии. М.: Изд. дом ВШЭ.

Кларк Б. 2011b. Создание предпринимательских университетов: организаџионные направления трансформачии. М.: Изд. дом ВШЭ.

Климова С. Г. 2006. «Челноки»: бегство от нужды или погоня за шансом? Социальная реальность. 2: $26-41$.

Об образовании. 1992. Закон Российской Федерации № 3266-1 от 10 июля 1992 г.

Об образовании. 2012. Закон Российской Федерации в редакции № 68 от 10 июля 2012 г.

Отношение преподавателей высшей школы к негосударственным вузам. Социологические исследования. 10: 126-132.

Павлюткин И. В. 2011. Конструирование университета как организации. Экономическая сочиология. 12 (1): 104-123. URL: http://ecsoc.hse.ru/data/2011/02/02/1234589797/ecsoc_t12_n1.pdf

Павлюткин И. В., Андрущак Г. В., Новиков А. В. 2010. Региональный атлас экономики высшего образования (показатели рынка): атлас. Йошкар-Ола: ООО «Полиграфическое предприятие Центр Принт».

Петренко Е., Галицкая Е., Шмерлина И. 2010. Ценность высшего образования. Вопросы образования. 2: $178-187$. 
Флигстин Н. 2003. Рынки как политика: политико-культурный подход к рыночным институтам. Экономическая соииология. 4 (1): 45-63. URL: http://ecsoc.hse.ru/data/362/588/1234/ecsoc_t4_n1.pdf

Щербакова И. В. 2006. Синяя птица российских челноков. Социальная реальность. 10. URL: http:// socreal.fom.ru/files/sr0610-054-083.pdf

Altbach P. G. 1999. Private HigherEducation: Themes and Variations in Comparative Perspective. PROSPECTS. 29 (3): 310-323.

Bjarnason S. et al. 2009. A New Dynamic: Private Higher Education. Paris: UNESCO; 8-13.

DiMaggio P., Powell W. 1983. The Iron Cage Revisited: Institutional Isomorphism and Collective Rationality in Organizational Fields. American Sociological Review. 48: 147-160

Geiger R. L. 1986. Private Sectors in Higher Education: Structure, Function, and Change in Eight Countries. Ann Arbor, Michigan: University of Michigan Press.

Kraatz M. S., Zajac E. J. 1996. Exploring the Limits of the New Institutionalism: The Causes and Consequences of Illegitimate Organizational Change. American Sociological Review. 61: 812-836.

Larsen I. M., Gornitzka A. 1995. New Management System at Norwegian Universities: The Interface between Reform and Institutional Understanding. European Journal of Education. 30: 347-361.

Levy D. C. 1986. Higher Education and the State in Latin America: Private Challenges to Public Dominance. Chicago: The University of Chicago Press.

Levy D. C. 1999. When Private Higher Education Does Not Bring Organizational Diversity: Argentina, China, Hungary. In: Altbach P. G. (ed.). Private Prometheus: Private Higher Education and Development in the 21st Century. Westport, Conn.: Greenwood; 17-50.

Levy D. C. 2004. The New Institutionalism: Mismatches with Private Higher Education's Global Growth. Program for Research on Private Higher Education. Working Paper. 3. Albany, NY: University at Albany.

Levy D. C. 2010. East Asian Private Education: Reality and Policy. Part of the World Bank Flagship Paper on East Asia. URL: http://siteresources.worldbank.org/INTEASTASIAPACIFIC/Resources/ EastAsianPrivateHigherEducation.pdf

Meyer J. W., Boli J., Thomas G. M. 1994. Ontology and Rationalization in the Western Cultural Account. In: Scott W. R., Meyer J. W. (eds). Institutional Environments and Organizations. Structural Complexity and Individualism. London: Sage; 9-28.

Meyer J. et al. 2007. Higher Education as an Institute. In: Gumport P. J. (ed.). Sociology of Higher Education. Baltimore, MD: Johns Hopkins University Press; 187-221.

Meyer J. W., Rowan B. 1977. Institutional Organizations: Formal Structure as Myth and Ceremony. American Journal of Sociology. 83 (2): 340-363. 
Meyer J. W., Rowan B. 2006. The New Institutionalism in Education. New York: SUNY Press.

Meyer J. W., Scott W. R. 1983. Organizational Environments: Ritual and Rationality. Beverly Hills, CA: Sage.

Pace C. R. 1962. Methods of Describing College Cultures. Teachers College Record. 63 (4): 267-277.

Peterson G. et al. (eds). 2001. Education, Culture and Identity in Twentieth-Century China. Hong Kong: University Press.

Schofer E., Meyer J. W. 2005. The World-Wide Expansion of Higher Education in the Twentieth Century. American Sociological Review. 70: 898-920.

Scott W. R. 1991. Unpacking Institutional Arguments. In: Powell W., DiMaggio P. (eds). The NewInstitutionalism in Organizational Analysis. Chicago: University of Chicago Press: 164-182.

Scott W. R. 1998. Organizations: Rational, Natural and Open Systems. Prentice Hall, NJ: Upper Saddle River.

Selznick P. 1957. Leadership in Administration. A Sociological Interpretation. New York: Harper \& Row.

Suspitsin D. 2005. Russian Private Higher Education: Alliances with State-Run Organizations. In: Altbach P., Levy D. (eds). Private Higher Education: A Global Revolution. Rotterdam: Sense Publications; 211-215.

Windolf P. 1997. Expansion and Structural Change: Higher Education in Germany, the United States, and Japan, 1870-1990. Boulder, CO: Westview Press.

Zumeta W. 1992. State Policies and Private Higher Education: Policies, Correlates, and Linkages. Journal of Higher Education. 63: 363-417. 


\title{
ПРОФЕССИОНАЛЬНЫЕ ОБЗОРЫ
}

\author{
И. С. Чириков
}

\section{Четыре способа определения организационных границ в социологии}

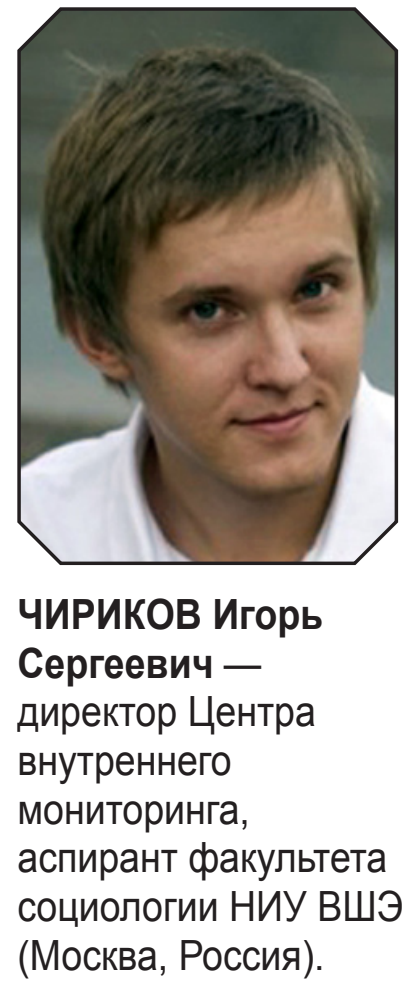

Email: igor.chirikov@ gmail.com
В данной работе сделана попытка кодификации теоретических ресурсов сочииологии организаций, связанных с изучением организаџионных границ. В результате были выделены и проанализированы четыре возможных способа кониептуализачии организаџионных границ в зависимости от базовой метафоры, которую предполагает тот или иной подход: граница как «мембрана» («клапан»); граница как «конвенция»; граница как «интерфейс» и гранииа как «лицо» («передний план»). Помимо этого в работе обсуждаются общие концептуальные ограничения существующих подходов в вопросе рассмотрения организаџионных границ.

Ключевые слова: организационные границы; теория контингентности; теория договорного порядка; теория ресурсной зависимости; новый институционализм в организационном анализе.

\section{Введение}

Формальные организации и бюрократии вот уже долгое время являются неотъемлемой частью социальной жизни. Они не только серьёзно трансформировали (и продолжают трансформировать) хозяйственную активность и все другие виды коллективной деятельности людей, но изменили само жизненное пространство человека. Тезис о том, что современное общество является обществом организаций [Coleman 1974; Perrow 1991; Perrow 2002], в котором корпоративные акторы играют ключевую роль, находит все больше сторонников в социальных науках. В то же время сам мир организаций не стоит на месте, изменяется организационный ландшафт целых отраслей и территорий [Piore, Sabel 1984]. Яркими примерами тому могут служить быстрое распространение так называемых сетевых форм организации в биотехнологической отрасли [Powell 1990] и Силиконовой долине в США [Saxenian 1996], появление новых торговых форматов в российском ритейле [Радаев 2007], формирование крупных университетов на основе слияния нескольких вузов в России, Китае и других странах [Саi 2011]. Фундаментальным процессом, объединяющим указанные примеры и заслуживающим более детального изучения, является трансформация организационных границ: в одних случаях границы перестают быть чётко очерченными и оказываются проблематичными для идентификации, в других - становятся более проницаемыми, расширяются, захватывая новые области деятельности, в третьих - постепенно исчезают, уступая место новым. Внимание к динамическим аспектам границ организаций позволит лучше понять особенности появления новых организационных форм, развитие паттернов кооперации и соперничества между корпоративными акторами, взаимодействие 
организации с внешней средой. В связи с этим задача кодификации основных социологических подходов к анализу организаций в зависимости от имплицитно заложенной перспективы рассмотрения организационных границ представляется весьма актуальной.

Вопрос о границах корпоративных акторов ${ }^{1}-$ один из фундаментальных для социологии организаций как отрасли социологического знания. По сути, это вопрос о том, чем является организация (и, напротив, чем она не является), что составляет её сущность и позволяет отличать её от других организаций и внешней среды. Как возможны границы организации? Какие концептуализации границ корпоративных акторов используются в социологических исследованиях организаций? В данной статье мы предпримем попытку кодификации различных социологических подходов к пониманию сущности организационных границ. Для разработки общей рамки такой кодификации нам представляется важным обратить внимание, что проблематика границ является производной от более общих концептуализаций корпоративных акторов. В то же время в социологии организаций в настоящее время отсутствует конвенциональная классификация, на которую можно было бы опереться для систематизации дискуссий об организационных границах. Существующие классификации зачастую включают в одну категорию перспективы, которые по-разному подходят к концептуализации организационных границ (см., например: [Burrell, Morgan 1979; Scott, Davis 2007]). Именно поэтому для целей данной статьи мы разработали оригинальную классификационную схему; она, с одной стороны, учитывает общую концептуальную близость подходов и, с другой - группирует вместе те из них, которые схожим образом концептуализируют отношение организации и её внешней среды, а, следовательно, в целом одинаково рассматривают проблематику организационных границ ${ }^{2}$. Мы выделяем четыре группы таких подходов ${ }^{3}$. Первая группа фокусируется на рассмотрении организации как социальной системы, поддерживающей свои границы и являющейся частью более общей системы, задающей её целевую ориентацию. Теоретико-методологическими основаниями данных подходов являются структурный функционализм, теория систем и эволюционная перспектива в социологии. Перспективы в рамках второй группы основываются на интерпретативной традиции в социологии и представляют организацию как некоторую коллективность, которая не существует вне постоянного взаимодействия и вырабатываемых символических конструктов. В рамках третьей группы подходов организация рассматривается в качестве плотной сети социальных обменов между акторами. И, наконец, четвёртая группа подходов опирается на ресурсы социологии знания и теорию социальной идентичности, а организация предстаёт в качестве социальной группы, структурированной особым образом в виде различных групп и ролей и соотносящей себя с другими организациями и институциональными структурами.

Теоретические подходы, о которых мы будем говорить далее, складываются преимущественно в 1970 1980-е гг. — время, когда социология организаций оформляется как самостоятельная дисциплинарная область. Именно тогда появляются такие направления, как теория контингентности (contingency theory $)^{4}$, популяционная экология, теория договорного порядка, теория ресурсной зависимости, сете-

1 Стоит сделать оговорку о том, что в рамках данной статьи мы рассматриваем термины «корпоративный актор», «формальная организация», «организация» как синонимичные, признавая возможность содержательных различий между ними в других контекстах и в рамках определённых теоретических перспектив.

2 Мы признаём, что организации являются внутренне структурированными сущностями, однако в рамках данной работы нас будут интересовать изучение не внутренних структурных границ, но границ между организацией и её внешним окружением.

3 Необходимо заметить, что рассматриваемые нами концептуализации не являются взаимоисключающими, они акцентируют внимание на разных аспектах изучения границ и, вероятно, могут дополнять друг друга. В то же время, безусловно, возможны и другие способы рассмотрения организационных границ, однако они пока не получили серьёзного распространения в социологии организаций.

4 В русскоязычной литературе встречаются и другие переводы данного термина, например «ситуационная теория» [Щербина 2000: 167-168]. Мы предпочли использовать перевод термина «contingency» как «контингентность», чтобы сохранить единство его употребления в социологических работах, восходящих к Т. Парсонсу. Автор благодарит анонимного рецензента и Г. Б. Юдина за указание на возможные варианты перевода. 
вые подходы, новый институционализм в организационном анализе. Мы фокусируемся в основном на указанных концепциях по следующим причинам. Во-первых, потому что именно они по-прежнему составляют концептуальное «ядро» социологии организаций. Несмотря на обширный эмпирический материал, собранный в рамках организационной теории в последние десятилетия, в теоретическом плане серьёзного продвижения сделано не было [Davis 2010; Интервью с Уолтером Пауэллом... 2012]. Во-вторых, потому что новые разработки, которые появляются в последнее время (например, приложения акторно-сетевой теории к исследованиям организаций), ещё не оформились в плане теоретического языка и логики, и осмысление их перспективы рассмотрения организационных границ является задачей будущего.

\section{1. Граница организации как «мембрана» («клапан»)}

Представление об организации как о системе долгое время было (а по мнению некоторых исследователей, остаётся и по сей день) одним из наиболее влиятельных в социологии организаций (см.: [Burrell, Morgan 1979: 121]). Системный подход в социологии отличается довольно высоким уровнем концептуального разнообразия. Само понятие «социальная система» продуктивно использовалось и разрабатывалось в работах Г. Спенсера, Э. Дюркгейма, В. Парето, Т. Парсонса, Н. Лумана и целого ряда других авторов. Кроме того, наработки общей теории систем, произведённые в рамках различных дисциплин (кибернетика, физика, биология), нашли своё отражение и в социальных науках.

Важный шаг в концептуальном развитии вопроса о границах социальных систем был сделан Т. Парсонсом, который представил теорию социальных систем в качестве одной из центральных тем социологии [Parsons 1951; Parsons, Shils, Olds 1951; Парсонс 1993]. Отталкиваясь от общей теории систем, Парсонс выделяет наиболее важные особенности эмпирически наблюдаемых систем, которые являются релевантными для анализа личностной и социальной подсистем действия [Parsons, Shils, Olds 1951: 107-109]. Во-первых, это взаимозависимость частей системы, заключающаяся в существовании установленных отношений между частями системы и определённого порядка, который является самоподдерживающимся (self-maintenance). Процесс поддержания порядка внутренними силами системы описывается при помощи понятия «равновесие». В свою очередь, равновесие необязательно рассматривается как статический, или стабильный, феномен; к нему также относятся процессы упорядоченного изменения, происходящего, например, в случае роста системы (динамическое равновесие). Во-вторых, эмпирически наблюдаемые системы характеризуются в определённом состоянии равновесия значительной степенью детерминированности отношений между их частями. И, наконец, в-третьих, Парсонс обращает внимание на то, что любая система существует и поддерживает равновесное состояние в определённых границах, установленных относительно окружения. Эти границы «не навязываются извне, они поддерживаются особыми качествами, которые присущи элементам системы в ходе её функционирования» [Parsons, Shils, Olds 1951: 108]. В своих рассуждениях Парсонс опирается на концепцию гомеостаза в биологии и физиологии, поэтому наиболее явной аналогией вновь выступает живой организм, который не перенимает физико-химические условия внешней среды, а поддерживает собственный, отличающийся набор этих условий, взаимодействуя с окружением. К примеру, температура тела млекопитающих остаётся относительно стабильной при самых разных температурах окружающей среды. Установленная граница, таким образом, позволяет (в известных пределах) поддерживать равновесие и целостность системы по отношению к колебаниям внешней среды.

Парсоновское представление об организации как о социальной системе оказалось крайне влиятельным в социологии организаций. Особого внимания заслуживают две концептуально различные перспективы рассмотрения организаций, которые были «вдохновлены» идеями Парсонса: концепция, предложенная Дж. Томпсоном и ставшая основой для формирования так называемой теории контингентности, и эволюционная перспектива изучения организаций. 
Одной из наиболее оригинальных попыток последовательного выстраивания концептуального аппарата для анализа организаций, основанного на концепциях Парсонса о социальных системах, являются работы Джеймса Томпсона [Thompson 1962; Thompson 1967]. Он предлагает рассматривать несколько уровней, или подсистем, деятельности организации - технический, управленческий и институциональный [Thompson 1967: 10-12] (см. также: [Parsons 1960: 60-65]). Деятельность на техническом уровне сосредоточена на проблемах эффективного выполнения технической функции, направленной на достижение (с учётом имеющихся для этого ресурсов) основной цели организации. В случае организации, создающей и реализующей определённый продукт, это будет непосредственно производственная деятельность, в случае школы - обучение учеников и т. п. Управленческий уровень предполагает деятельность по проектированию и контролю производственного процесса; на этом уровне устанавливаются рабочие принципы для достижения целей, а также происходит упорядочивание отношений, связанных с реализацией конечного продукта, определяются масштаб и характер деятельности, параметры найма, маркетинговая политика и проч. Деятельность, осуществляемая на институциональном уровне, обеспечивает связь организации с более общей системой, создаёт условия её легитимации. Примерами могут служить PR-службы, юридические департаменты, наблюдательные и попечительские советы.

Ключевая идея Томпсона заключается в том, что организации стремятся максимально обезопасить (seal off) технический уровень деятельности, где предсказуемость особенно важна для рационального осуществления, от непредсказуемых воздействий внешней среды [Thompson 1967: 24]. Полная изоляция от влияния внешней среды невозможна, поэтому организация стремится создать на своих границах некую буферную зону. Граница предстаёт в качестве выделенной зоны деятельности организации и предполагает специальные задачи, характеристики занятости и проч. Для взаимодействия с элементами окружения и «защиты» технического уровня деятельности от влияния неопределённости внешней среды, организации создают специальные структурные единицы на своих границах (boundaryspanning units) [Thompson 1967: 70-73]. Приведённое понятие выражает сущность понимания границ через категорию деятельности.

Параметры и свойства подобных подразделений, находящихся на границах, во многом зависят от гетерогенности (многообразия) и изменчивости целевого окружения. Томпсон делает ряд предположений относительно связи между целевым окружением и подразделениями на границах. Чем более гетерогенным и динамичным является целевое окружение, тем больше ограничений и непредвиденных обстоятельств содержится в нём для организации. В этом случае организация стремится установить как можно больше узкоспециализированных подразделений на границах, которые будут иметь дело с ограниченным набором элементов целевого окружения [Thompson 1967: 73]. Если подразделения на границах и технический уровень организации относительно изолированы друг от друга (за исключением их синхронизации в рабочем графике), то организации будут отличаться централизацией, интегрирующей набор некоторых функциональных подразделений. И, напротив, когда подразделения на границах и технический уровень характеризуются реципрокной взаимозависимостью, они образуют самодостаточные кластеры, децентрализованные относительно друг друга [Thompson 1967: 75-76]. Характер деятельности в рамках подразделений на границах также различается в зависимости от степени гетерогенности целевого окружения: когда оно относительно гомогенно и стабильно, то это, как правило, рутинизированная, стандартизированная деятельность, а в случае динамичного и неоднородного окружения работа носит творческий, непредсказуемый характер и сложна для оценивания в терминах эффективности. Организации тогда становятся крайне зависимыми от деятельности, осуществляемой на границах, и стремятся уменьшить эту зависимость [Thompson 1967: 110-112].

Ещё одним подходом, представители которого концептуально близки к системному взгляду на границы, является эволюционная перспектива изучения организаций. Необходимо оговориться, что мы рассматриваем лишь один из подходов в рамках эволюционной перспективы анализа организаций, 
который развивается Х. Олдричем и рядом его коллег [Aldrich 1971; Aldrich 1979; Aldrich, Ruef 2006]. Для этого подхода характерны некоторые отличия от популяционной экологии организаций [Hannan, Freeman 1977; Hannan, Freeman 1989; Hannan, Polos, Carroll 2007], более узкого направления, сфокусированного на проблематике отбора и признающего крайне слабую роль процесса организационной адаптации в силу структурной инерции (см. подробнее: [Aldrich, Ruef 2006: 35-38]). Для Олдрича понятие «границы» выступает ключевым элементом определения организаций, которые рассматриваются как «целеориентированные, системы деятельности, поддерживающие свои границы (boundarymaintaining)» [Aldrich 1979: 4]. В этом случае также прослеживается связь с парсоновским пониманием организации и организационных границ: деятельность участников организации ориентирована на достижение определённых целей, а поддержание границ позволяет выстраивать взаимодействие с внешней средой. Возможность устанавливать границы является критичной для достижения определённой автономии по отношению к внешней среде. Если границы становятся проницаемыми и нечёткими, это означает изменение позиции конкретной организации в рамках её популяции. Процесс поддержания границ особенно заметен, когда происходят попытки извне нарушить установленные границы и принципы участия [Aldrich 1979: 5].

Важнейшим для эволюционной перспективы изучения организации является понятие «организационная форма» - «специфическая конфигурация целей, границ и способов деятельности» [Aldrich 1979: 28]. Именно организационная форма выступает ключевой единицей эволюционного процесса: организационные изменения осуществляются либо за счёт того, что старые организационные формы замещаются новыми, либо вследствие модификации существующих организационных форм ${ }^{5}$. Базовые типы организационных форм в зависимости от способа поддержания границ формируются на пересечении различных вариантов ответов на следующие вопросы: (1) может ли актор самостоятельно принимать решение об участии или неучастии в организации; (2) может ли организация контролировать условия входа; (3) может ли организация контролировать условия выхода? Чем меньше организация контролирует условия участия и принципы установления границ, тем больше она подвержена влиянию факторов окружающей среды и, в конечном счёте, эволюционным изменениям.

Подытожим основные идеи данного раздела. Базовой метафорой, которая характеризует общую перспективу рассмотрения организационных границ данной группой подходов, является физиологическая метафора ${ }^{6}$ «мембраны», или «клапана». Организация понимается как интегрированная социальная система, поддерживающая свои границы и представляющая собой часть более общей системы, легитимирующей её целевую ориентацию и принципы деятельности. Границы организации рассматриваются как ресурс адаптации системы к внешнему окружению, формирующий внутреннюю согласованность организации по сравнению с её внешней средой.

\section{2. Граница организации как «конвенция»}

Кардинально отличающийся «словарь» для концептуализациии организационных границ был предложен в рамках интерпретативной, или феноменологической, традиции в социологии, представители которой фокусируются на идентификации субъективного смысла действия. Во многом этот словарь создавался в полемике с представителями системного подхода и структурного функционализма.

5 И в этом случае можно вновь зафиксировать контрастность подхода Олдрича популяционной экологии Хэннана и Фримена, которые утверждают, что изменение существующих организационных форм, видоизменяющихся под влиянием факторов внешней среды, — явление маловероятное в силу структурной инерции. Олдрич придерживается точки зрения, что отдельные элементы организационных форм могут изменяться под влиянием эволюционного процесса [Aldrich, Ruef 2006: 35-38].

6 Здесь и далее мы будем обобщать итоги раздела, указывая некоторую метафору, отсылающую к ключевым характеристикам группы подходов в отношении организационных границ. При этом мы допускаем возможность некоторой многозначности в трактовке каждой метафоры, однако считаем, что это удобный способ обозначения или маркирования рассматриваемых нами групп подходов. 
Взгляд на организацию как социальную систему, поддерживающую свои границы по отношению к изменчивому внешнему окружению, подвергается серьёзному пересмотру. Организации с точки зрения интерпретативной перспективы не являются такими уж осязаемыми и упорядоченными сущностями, как их описывают представители системного подхода: они не существуют вне действий и интерпретаций участников, создаются и воспроизводятся в ходе постоянного взаимодействия и коммуникации [Burrell, Morgan 1979: 273-274]. Теоретико-методологические основания интерпретативной теории деятельности задаются корпусом работ Г. Зиммеля, Дж. Г. Мида, А. Щюца, Х. Гарфинкеля и др. [Девятко 2003: 98].

Среди классиков социологии одним из первых к проблематике границ социальных групп обращается Г. Зиммель [Simmel 1898; Simmel 1950; Simmel 1992; Simmel 2007]. В работе «Устойчивость социальных групп» [Simmel 1898] он задаётся вопросом о том, каким образом социальная группа продолжает оставаться той же самой, несмотря на то что её участники постоянно меняются. Каким образом возможно говорить о том же самом государстве, о той же самой общине или армии, несмотря на то что уже не осталось ни единого члена изначально образованных групп [Simmel 1898: 668]? Зиммель выделяет два измерения, в которых реализуется непрерывность группового единства, - пространственное и временное. Участок пространства, места, территории, где «живёт» социальная группа, является базовым основанием и отправной точкой для её непрерывности. При этом отмечается, что локальность не единственный элемент, который конституирует групповую протяжённость: существуют множество групп, которые не обладают общностью места [Simmel 1898: 669]. Более важным для сохранения непрерывности социальной группы является связь «поколений», выраженная во временном измерении. Зиммель обращает внимание на то, что наличие границ, по сути, делает возможным существование социальной группы, поскольку проясняет и актуализирует общие основания, нормы и ценности. Предельное выражение зиммелевских взглядов на важность изучения границ для понимания социальной жизни представлено в работе чикагского социолога Э. Эббота [Abbott 1995], чей главный тезис состоит в следующем: мы привыкли размышлять о границах «в подчинённой форме», как будто бы они проводятся между заранее существующими социальными образованиями (группами, организациями, профессиями и т. п.). Эббот предлагает пересмотреть онтологический статус границ, утверждая, что соотношение между ними и социальными сущностями обратное: сущности образуются только тогда, когда акторы определённым образом устанавливают социальные границы [Abbott 1995: 860]. Другими словами, необходимо в первую очередь обращать внимание на то, каким образом посредством соединения и перемещения границ люди формируют различные социальные сущности.

Однако важно обратиться к такому вопросу: что представляют собой границы коллективностей и социальных групп, понятые «с точки зрения действующего»? Очевидно, что они имеют символическую природу, являясь символическими категоризациями, которые задействуются акторами для различения объектов, практик и коллективностей. Ламон и Молнар, проводя различение между символическими и социальными границами, отмечают, что символические границы являются «средствами, при помощи которых индивиды и группы соперничают и достигают соглашений относительно определения реальности» [Lamont, Molnar 2002: 168]. Границы, таким образом, упорядочивают, структурируют поток взаимодействий, придавая ему осмысленность и паттернированность.

Далее мы обратимся к одному из наиболее известных подходов к анализу организаций в рамках интерпретативной перспективы - рассмотрению организации как «договорного порядка» ${ }^{7}$. Теория договорного порядка (negotiated order theory) в исследовании организаций подчёркивает прежде всего процессуальный, развёртывающийся характер организационных феноменов, которые возникают, воспроизводятся и трансформируются сознательными усилиями членов организации. Эти усилия конституируют социальный порядок организации: «Порядок есть то, над чем должны постоянно работать

7 При описании характеристик теории договорного порядка заимствованы отдельные фрагменты из опубликованной нами ранее статьи, посвящённой рассмотрению объяснительных возможностей данной перспективы [Чириков 2010]. 
члены любого общества и любой организации. Обоюдные соглашения, юридические договоры, которые конституируют основания для ожидаемой, предсказуемой и общепризнанной упорядоченности, не существовали вечно. Соглашения, договоры, правила всегда имеют временное измерение... Основания для согласованного действия (социальный порядок) должны постоянно (вос)производиться, или, другими словами, быть выработанными» [Strauss et al. 1963: 148]. Организационные границы, таким образом, предстают как временный продукт взаимодействия между людьми, который в любой момент может быть подвергнут доработке и пересмотру.

На концептуальном уровне теория договорного порядка тесно связана с символическим интеракционизмом, откуда её представители почерпнули процессуальное и ситуативное понимание социального действия. Для исследований социальной организации в русле теории договорного порядка особенно важными являются понятия «переговоры», «конвенции», «коллективные действия». Организация динамична и может изменяться, однако взаимодействия в рамках организаций не являются полностью случайными, они паттернированы установившимися конвенциями (в беккеровском смысле; см.: [Becker 1974]), рутинизированными, разделяемыми, привычными и принимаемыми на веру способами действия, коммуникации, понимания, разрешения ситуаций. И, наконец, переговоры позволяют индивидам осуществлять коммуникативную пристройку друг к другу в проблемных ситуациях, определять, уточнять и творчески изменять существующие категоризации и конвенции. Именно переговоры играют решающую роль в становящихся организациях и организационных изменениях.

Организационные границы, понимаемые с точки зрения теории договорного порядка, являются символическими конструкциями, установленными конвенциями относительно существующих структурных ограничений и принципов деятельности, которые создаются и воспроизводятся в ходе переговорного процесса. Важными концептуальными основаниями выступают понятия «обобщённый другой» (generalized other) Дж. Г. Мида и «конвенция» Х. Беккера. Мид рассматривал процесс детской социализации как игру, в которой выделяется два основных этапа: «игра-рlay» и «игра-game» ${ }^{8}$ [Mead 1934: 152-164]. На первой стадии («игра-play», или стадия «играния») ребёнок пытается подражать и вести себя так, как другие ведут себя в типических обстоятельствах. Например, он может играть в пожарного или доктора; при этом, поскольку его представления о них крайне смутны, он пытается уловить самые значимые характеристики. «Игра-рlay» происходит за пределами актуальных ситуаций взаимодействия, ребёнок учится понимать, что есть разные роли, что они различаются между собой, и, чтобы овладеть ими, нужны определённые усилия. В «игре-game» (или «соревновательной игре») нет предзаданных способов следования роли, в ней задана лишь общая ситуация (правила), и нужно действовать с учётом реакций других людей. Занятие определённой позиции в «игре-game» подразумевает знание ролевых позиций других людей, с которыми происходит взаимодействие.

Как утверждает Мид, степень обобщённости позиции другого может быть разной — от конкретного партнёра по взаимодействию или же обобщённых образов людей определённой профессии (медик, почтальон) и до позиции «семья», «группа», «организация». Отношение или позиция «обобщённого другого» есть отношение или позиция всего сообщества [Mead 1934: 155], которая образуется и фиксируется в языке. «Обобщённый другой» воплощает в себе применительно к данному социальному контексту определённый набор возможных действий или реакций на мои действия. Однако что составляет сущность позиции «обобщённого другого» применительно к разного рода организациям? Чтобы ответить на этот вопрос, мы обратимся к предложенному Х. Беккером понятию «конвенция», которое описывает условия и правила коллективных действий. Это понятие является близким к таким традиционным социологическим понятиям (или даже взаимозаменяемым с ними), как «норма», «правило», «согласие», «привычка» или «обычай» (folkway), — все они описывают те идеи и соглашения, которые имеются у людей во время их совместной деятельности (cooperative activity) [Becker 1974: 771].

8 Ввиду отсутствия устоявшихся способов перевода мидовских терминов «рlay» и «game» мы решили прибегнуть к различению двух указанных типов «игры» при помощи конструкции «игра-play» и «игра-game». Содержательные различия между ними проясняются далее в тексте. 
Конвенции включают цели деятельности, а также выбор и способ использования средств. Конвенции также устанавливают границы различения одной организации от другой, определяя специфику работы и социальных отношений.

Таким образом, базовой метафорой организационных границ для различных подходов в рамках интерпретативной перспективы является метафора «конвенции». Организация предстаёт в качестве коллективности, возникающей как результат договорного порядка, не существующей вне взаимодействия и каждодневно вырабатываемых символических конструктов и общего языка. Границы организации это символические конструкции, установившиеся конвенции относительно существующих структурных ограничений и принципов деятельности, которые создаются и воспроизводятся в ходе переговорного процесса.

\section{3. Граница организации как «интерфейс»}

Следующая группа подходов к рассмотрению организационных границ в каком-то смысле возникла в результате попыток синтеза различных элементов теории социальных систем и интерпретативистской перспективы, а также интеграции в организационную социологию проблематики властных отношений и межгруппового взаимодействия [Burrell, Morgan 1979: 87]. Концептуальный аппарат интересующих нас подходов сформировался под влиянием необихевиористских теорий обмена [Skinner 1953; Homans 1958; Homans 1961; Emerson 1962] (см. также обзор в кн.: [Девятко 2003: 229-242]).

Наибольшую значимость для социологии организаций имеют теоретические разработки Р. Эмерсона и Дж. Коулмана, эксплицитно фокусированные на проблематике социальной структуры и корпоративных акторов [Emerson 1962; Coleman 1990].

Основные положения развиваемой Эмерсоном, а также рядом его учеников и коллег теорий сетей социальной власти и (или) зависимости можно сформулировать следующим образом [Cook, Cheshire, Gerbasi 2006]: (1) человеческое поведение мотивировано желанием получить определённую выгоду и избежать потерь; (2) отношения обмена развиваются в структурах взаимной зависимости (обе стороны нацелены на включение в отношения обмена для получения желаемых ресурсов); (3) акторы вовлечены в повторяющиеся, взаимозависимые обмены с определёнными партнёрами в течение определённого промежутка времени (то есть не рассматриваются единичные обмены); (4) результаты обмена подчиняются экономическому закону убывающей предельной полезности (или психологическому принципу пресыщения).

Особое внимание заслуживает пункт 2. Эмерсон развивает идеи, сформулированные Хомансом, однако отмечает, что необходим другой подход к рассмотрению социального контекста, который окружает процесс обмена, а именно более основательное изучение структур власти и влияния. Очевидно, что между социальным обменом и властными отношениями существует определённая зависимость: сам факт, что одни акторы обладают бо́льшими ресурсами, чем другие, приводит к отношениям неравенства в ходе обмена [Emerson 1962]. Власть (power), тем самым, является реляционной характеристикой и выступает функцией зависимости одного актора от другого. Иначе говоря, «власть актора $A$ над актором $B$ - это количество сопротивления со стороны $B$, которое $A$ потенциально может преодолеть» [Emerson 1962: 32]. Содержание отношений зависимости может быть самым разным и включает различные наборы ресурсов и целей, которые нуждаются в дальнейшей операционализации.

Исходя из целей данной статьи, наибольший интерес для нас представляет переход от диадических форм обмена к обменам, включающим трёх акторов и более, то есть к сетевым формам обмена. По мнению Эмерсона, любое диадическое отношение, будучи включённым в более широкую сеть обменов, начинает зависеть от свойств этой сети [Девятко 2003: 240]. Сама реляционная концепция власти в 
действительности более применима к сетевым формам обмена, поскольку в рамках диадических обменов отсутствуют альтернативы другому участнику [Cook, Cheshire, Gerbasi 2006]. Для понимания того, как представители теории обмена подходят к рассмотрению границ сетей обмена, важно остановиться на двух темах: понятие «организованная группа» (organized group) и типы отношений обмена.

Понятием «организованная группа» Эмерсон обозначает один из способов формирования социальной структуры в сетях обмена [Emerson 1962: 37-39]. Социальная структура в более широком смысле мыслится им как эмерджентное свойство процессов социального обмена, или фактор, который, с одной стороны, ограничивает, а с другой - делает возможными определённые типы обмена. Организованная группа как особый вид социальной структуры также возникает вследствие отношений обмена и распределения власти между акторами. Обычно основным мотивом формирования группы является стремление к изменению распределения власти между участниками сети: к примеру, два участника, обладающие меньшей властью по отношению к третьему участнику, могут объединиться против него. Такую форму организованной группы Эмерсон называет коалицией. Указанные два участника, таким образом, создают коллективного актора, который действует как единое целое по отношению к их окружению (в нашем случае оно представлено третьим актором). Организованная группа характеризуется, во-первых, общей внешней средой в виде актора, чьи действия она стремится контролировать, и, во-вторых, исторически сформированным единством, проистекающим из задачи этого контроля. Заключительный элемент, необходимый при определении организованной группы, - это процедура «обезличивания» ${ }^{9}$ понятия «окружение»: контроль действий третьего участника является не самоцелью, а скорее средством для достижения определённой цели [Emerson 1962: 37]. Формирование группы в рамках сети изменяет паттерны обменов, в результате чего образуются групповые нормы и ролевые предписания в виде требований коллективного актора, и, тем самым, уже группа приобретает специфическую власть над индивидуальными акторами. Как правило, внутри организованной группы, состоящей более чем из трёх акторов, формируются процессы обобщённого обмена (generalized exchange), в рамках которого вознаграждение, получаемое актором, не всегда имеет прямую зависимость от его вклада и ресурсов [Yamagishi, Cook 1993]. Таким образом, граница коллективных акторов в рамках сетей обменов понимается как обозначение некоторого типа отношений обмена, установленного между индивидуальными акторами. Этот тип отношений нацелен на особый способ взаимодействия с внешней средой и характеризуется практиками обобщённого обмена.

Однако указание на формирование специфических отношений обмена является недостаточным признаком для определения границ организованных групп. Последователи Эмерсона вводят различение между тремя классами отношений, существующих в рамках сетей обменов [Cook, Yamagishi 1992]: (1) непосредственно отношения обмена, которые формируют сети обменов и организованные группы в рамках этих сетей; (2) латентные отношения, которые оставляют возможности для появления отношений обмена, но при этом не используются в данный момент (потенциально могут быть задействованы для обмена); (3) отсутствующие отношения (non-relations), которые никогда не используются и не могут быть использованы. Основное различие между отношениями второго и третьего типов состоит в том, что латентные отношения влияют на распределение властных отношений в сети, и при их модификации распределение власти изменится (в отличие от отсутствующих отношений). Существование латентных отношений в рамках сети указывает на ещё один аспект, который отличает концептуализацию границ коллективных акторов в рамках теорий обмена: граница выступает в качестве потенциального «интерфейса» для формирования новых отношений обмена.

9 Под «обезличиванием» Эмерсон имеет в виду, что чаще всего формирование организованной группы происходит не для контроля действий определённого человека, но для достижения автономии по отношению к некоторым абстрактным позициям в рамках сети. Возможность контроля этих позиций позволяет организованной группе достигать поставленных целей. 
Далее рассмотрим реализацию идей Эмерсона и других теоретиков обмена на примере теории ресурсной зависимости [Pfeffer, Salancik 1978], хотя стоит также отметить серьёзную роль, которую данные идеи играют в рамках сетевых подходов к анализу организаций.

Центральный тезис теории ресурсной зависимости состоит в том, что существование организаций практически полностью зависит от характеристик сетей обменов, в которые она включена. Организации не являются самодостаточными образованиями, они в большой степени ограничены и стеснены условиями, формируемыми для них внешней средой, следовательно, на передний план выходит не изучение внутриорганизационных процессов и решений руководителей, а анализ социальных сетей и взаимодействий, в которые включена организация. Организации вынуждены взаимодействовать с различными элементами сетей обмена ресурсами, в которые они включены. Ключевым фактором, определяющим зависимость организации от прочих организаций или групп внешней среды, является способность контролировать получение ресурсов (как материальных, так и символических), необходимых для существования организации [Pfeffer, Salancik 1978: 44]. Именно вопрос получения ресурсов организациями (а не эффективного использования этих ресурсов) является центральным сюжетом теории ресурсной зависимости.

Для того чтобы контролировать процесс получения ресурсов, уменьшить свою зависимость от элементов внешней среды и повысить степень автономии для реализации собственных целей, организации стремятся выстроить определённые стратегии взаимодействия с другими организациями и группами - поставщиками, конкурентами, правительственными учреждениями. Конкретные наборы действий по отношению к внешней среде, безусловно, зависят как от характеристик интересующей нас организации, так и от характеристик элементов внешней среды. Пфеффер и Саланчик выделяют следующие группы стратегий [Pfeffer, Salancik 1978: 92-224]:

— принятие требований других организаций и групп: такого рода стратегия хотя и возможна (и зачастую декларируется менеджерами организаций в качестве основной), однако проблематична, поскольку отдельные элементы сети предъявляют различные, порой несовместимые требования (например, требования повышения производительности, снижения цен и заботы об экологии);

— избегание влияния со стороны других организаций и групп: организации могут попытаться избежать предъявления требований от некоторых элементов сетей обмена, например, за счёт закрытия доступа к информации, введения режимов секретности, нахождения альтернативных контрагентов и альтернативных источников ресурсов;

- слияния и поглощения отдельных элементов сети обмена для уменышения зависимости: увеличение степени контроля организации над внешней средой может быть достигнуто вертикальными, горизонтальными слияниями, а также диверсификацией. Слияния также позволяют увеличить размер организации, который также положительно сказывается на её возможностях контроля изменений внешней среды;

— кооптация: включение отдельных элементов внешней среды в организационные структуры (например, через наблюдательные советы, переплетённые директораты и т. п.). Данная стратегия позволяет организации установить связи с различными внешними группами и организациями, повысить легитимность. В терминах Селзника, это обмен автономии на поддержку [Selznick 1949]; 
- установление коллективных структур для совместных действий: к таким структурам относятся совместные предприятия, ассоциации, альянсы, которые позволяют достигать коллективных целей, недоступных каждой из организации в отдельности;

— изменение законодательных условий: данная стратегия заключается в изменении «правил игры», которыми определяется та или иная зависимость.

Таким образом, организация рассматривается в качестве взаимоструктурированных видов деятельности, на которые распространяется возможность распоряжения ими (discretion) и которые она может самостоятельно начинать, поддерживать и завершать [Pfeffer, Salancik 1978: 32]. По сути, подобная трактовка сходна с концепцией власти индивидуального или коллективного актора, предложенной Эмерсоном. Следовательно, организация «заканчивается» там, где её возможности осуществлять контроль над различными элементами сетей обмена ресурсами меньше, чем возможности другой организации или индивидуального актора.

Таким образом, в качестве центральной метафоры для характеристик организационных границ выступает метафора «интерфейса». Организация рассматривается как относительно замкнутая сеть социальных обменов между индивидуальными акторами, преследующими общую цель, которая укоренена в сетях взаимодействий между другими индивидуальными и коллективными акторами. Границы организаций при этом имеют две отличительные черты: они (1) формируют особый тип отношений обмена между индивидуальными акторами внутри сети; (2) позволяют в различных режимах осуществлять «подключение» других индивидуальных и коллективных акторов к существующим сетям обмена.

\section{4. Граница организации как «передний план» («лицо»)}

Последняя группа подходов к анализу организаций, на которую следует обратить внимание при обсуждении концептуализации организационных границ, опирается на понятие «идентичность» в качестве центральной объяснительной категории. Понятие «идентичность», как и понятие «система», продуктивно задействуется представителями самых разных дисциплин - психологии, социологии, антропологии, философии и др., а потому и в социологии интеллектуальные основания этого термина довольно разнородны. Применительно к интересующему нас вопросу организационных границ оно подчёркивает важную роль внутри- и внеорганизационных определений и категоризаций для их формирования и изменения: границы как некоторые устойчивые категоризации и определения «что есть организация» появляются в результате соотнесения организации с другими корпоративными акторами или институциональными структурами. Далее мы рассмотрим основания и теоретические аргументы относительно организационных границ, предлагаемые в рамках нового институционализма в организационном анализе.

Как отмечают П. Димаджио и У. Пауэлл, перспектива нового институционализма «акцентирует внимание на способах структурирования действия и возникновения порядка за счёт разделяемых систем правил, которые как ограничивают предпочтения и возможности акторов... так и создают преимущества для отдельных групп, чьи интересы защищены существующими способами поощрения и принуждения» [DiMaggio, Powell 1991: 11]. Применительно к анализу организаций новый институционализм отличается от старого, характерного для теоретических построений Т. Парсонса и Ф. Селзника, по целому ряду базовых допущений. Наиболее важными представляются два различия. Прежде всего, представители старого и нового институционализма расходятся в концептуализации внешней среды организации. Первые говорят о внешнем окружении как о локальном сообществе, состоящем из других организаций, групп влияния, ассоциаций и т. п., с которым организация непосредственно взаимодействует. Вторые рассматривают окружение как организационное поле, то есть те «организации, 
которые в совокупности составляют идентифицируемую сферу институциональной жизни — это ключевые поставщики, потребители ресурсов и продуктов, регуляторы и другие организации, производящие сходные продукты или услуги» [Димаджио, Пауэлл 2010: 37]. Кроме того, у «старых» и «новых» институционалистов различаются представления об основаниях действий людей в организациях. Если в старом институционализме больший акцент делается на общих ценностях, нормах и установках, которые интернализируются участниками организаций в ходе организационной социализации, то для «нового» институционализма характерны рассуждения о формировании этих оснований как о когнитивном процессе: сущность организаций выражается не в нормах и ценностях, но в принимаемых на веру правилах, классификациях, схемах и планах [DiMaggio, Powell 1991: 15].

Важно обратить внимание на последнее различение, поскольку оно указывает на одно из наиболее важных теоретических оснований нового институционализма - социальный конструкционизм, акцентирующий внимание на «сконструированной объективности» институционального мира. Дж. Мейер и Б. Роуэн, ссылаясь на классическую работу П. Бергера и Т. Лукмана, отмечают, что «институционализированные правила - это классификации, встроенные в общество как взаимные типизации или интерпретации» [Мейер, Роуэн 2011: 45]. Процесс создания институционализированных правил (институционализация), с точки зрения Бергера и Лукмана, подразумевает три взаимосвязанных этапа: (1) экстернализация - создание в ходе взаимодействия символических структур, чей смысл разделяется участниками; (2) объективация - процесс, позволяющий экстернализированным продуктам человеческой деятельности приобрести характер объективности; и (3) интернализация, переводящая в ходе социализации объективированный социальный мир в сознание индивидов [Бергер, Лукман 1995]. Институты предстают в качестве продуктов социального взаимодействия, но, будучи созданы и поддерживаемы людьми, они при этом контролируют человеческое поведение, устанавливают его образцы, которые придают действиям людей одно из нескольких возможных направлений. Данная перспектива идёт вразрез с менеджериально ориентированными подходами, рассматривающими организационную идентичность как «уникальную сущность» организации, включающую те характеристики, которые являются для неё центральными, отличительными и длительными [Albert, Whetten 1985]. «Новых» институционалистов, скорее, интересуют общие для организаций элементы идентичности, к примеру, для университета — вхождение в топ-100 рейтинга, для футбольного клуба - участие в Лиге чемпионов и т. п.

Институциональное окружение играет крайне важную роль применительно к организациям: элементы институциональной среды, относящиеся к деятельности организаций (характеристики продуктов, способы оказания услуг, технологии, стратегии и т. п.), функционируют в качестве «влиятельных мифов», которым необходимо следовать для того, чтобы деятельность воспринималась как легитимная [Мейер, Роуэн 2011: 45]. Следовательно, современные организации следует рассматривать не как отдельные единицы, взаимодействующие со средой, а как сосредоточение рационализированных мифов, характерных для определённых обществ. Каждая организация интернализирует эти влиятельные мифы, однако, поскольку они зачастую не соответствуют критериям эффективности и противоречат друг другу, организации вынуждены в своей деятельности устранять эти несоответствия.

Среди возможных решений устранения такого несоответствия представители «нового» институционализма выделяют два основных механизма: расцепление (decoupling) и заботу о «сохранении лица» (face-work) [Мейер, Роуэн 2011: 59-63]. Оба механизма характеризуют отношения между организацией и её институциональной средой (и, следовательно, реализуются на организационных границах). Также они позволяют достигать изоморфизма и легитимации организации по отношению к внешней среде, что крайне важно для её выживания и получения ресурсов [Димаджио, Пауэлл 2010]. Механизм расцепления представляет собой слабую связь и низкую степень скоординированности между отдельными структурными элементами и деятельностью организации. Подобная слабая связь позволяет организа- 
циям защищать свои формальные структуры от оценивания их технической производительности, поскольку любые попытки эксплицировать взаимосвязи и эффективность работы отдельных структурных элементов институционализированных организаций неизбежно приведут к выявлению различных несоответствий. По сути, расцепление - это установление границ между институциональной средой (её частью являются интернализируемые мифы) и деятельностью, которая может выстраиваться исходя из «практических соображений», то есть профессиональных знаний, складывающихся межличностных отношений и т. п. [Мейер, Роуэн 2011: 60-61]. В соответствии с логикой социального конструкционизма границы понимаются как категоризации и взаимные типизации, создающиеся и функционирующие в ходе взаимодействия участников организации с её внешней институциональной средой.

Однако демаркационной (разделяющей) роли границ недостаточно для существования организаций, и, помимо расцепления организации и её внешней среды, граница должна их связывать определённым образом. Эта «связка» достигается за счёт механизма, обозначенного Мейером и Роуэном, вслед за И. Гофманом, как забота о «сохранении лица» [Goffman 1967: 12-18; Мейер, Роуэн 2011: 61]. Данный механизм необходим для того, чтобы как члены организации, так и представители внешнего окружения были убеждены в том, что деятельность организации консистентна институционализированным мифам. Термин «лицо» понимается Гофманом как «образ себя, определяемый в терминах одобряемых социальных характеристик, хотя он может одновременно распространяться и на других людей, например, если человек, достойно представляя самого себя, тем самым достойно представляет свою профессию или религию» [Goffman 1967: 5]. В нашем случае человек, стремясь сохранить собственное лицо, работает и на поддержание «лица» организационной идентичности, которая является частью его собственной. Далее, «если индивидуальным участникам гарантировано сохранение лица, это поддерживает уверенность (членов организации и внешних контрагентов. - И. Ч.) в организации и в конечном счёте укрепляет уверенность в мифах, которые рационализируют существование организации» [Мейер, Роуэн 2011: 61]. Работа по «сохранению лица» может осуществляться с помощью различных техник: избегание (avoidance) ситуаций, в которых человек мог бы «потерять лицо»; проявление осторожности (discretion) и церемониального обращения в проблематичных ситуациях; игнорирование неблагоприятных инцидентов [Goffman 1967: 15-18]. И если постпарсонсовская социология организаций опирается на понятие «система, поддерживающая границы», то в «новом» институционализме, задействовав рассуждения Гофмана, говорят об организациях, поддерживающих «лицо» (maintaining face) по отношению к окружающим их институциональным структурам. Гофман также опирается на понятие «равновесие» (или, точнее, «ритуальное равновесие»), осуществляемое в ходе взаимодействия через несколько фаз корректировочного процесса: вызов, искупление, принятие и благодарность [Goffman 1967: 20-22].

Итак, организационные границы позволяют, с одной стороны, за счёт механизма расцепления сделать возможной коллективную деятельность организации, функционирующей в сильно институционализированных средах, а с другой стороны, за счёт работы по «сохранению лица» установить церемониальное соответствие деятельности и мифов институциональной среды. Границы фигурируют как некоторые устойчивые категоризации, определения, формирующиеся соотнесением организаций и институциональных структур, а как базовая метафора для их описания выступает метафора «лицо», или «передний план».

\section{Заключение}

В данной статье мы попытались очертить пространство социологических подходов к изучению организационных границ и провести кодификацию различных перспектив в социологии организаций. Были выделены четыре возможных способа концептуализации организационных границ в зависимости от 
базовой метафоры, которую предполагает тот или иной подход: (1) граница как «мембрана» («клапан»); (2) граница как «конвенция»; (3) граница как «интерфейс» и (4) граница как «лицо» («передний план»).

В то же время проведённый анализ показал, что рассмотренные нами социологические подходы к анализу организаций обладают определёнными ограничениями, которые могут быть сформулированы следующим образом:

1. Каждая из рассмотренных нами в данной статье перспектив социологии организаций концентрирует внимание лишь на одном аспекте, связанном с организационными границами. Так, группа подходов, рассматривающих организацию в качестве интегрированной социальной системы, поддерживающей свои границы, фокусируется на роли границ как некоторого «разделителя» того, что находится внутри системы и что - вне её. Интерпретативные подходы обращают особое внимание на феномены, посредством которых границы упорядочивают внутренние паттерны взаимодействия, практически игнорируя процессы более высокого порядка. Для подходов, базирующихся на теориях социального обмена и сетевых теориях, граница выступает важным концептуальным ресурсом для понимания того, как осуществляется связь организаций и элементов внешней среды. И, наконец, подходы, акцентирующие внимание на понятии «идентичность», рассматривают границы как устойчивые категоризации, которые имеют реляционную природу и определяют организацию по отношению к другим корпоративным акторам и институциональным структурам. Следовательно, каждая из рассмотренных нами перспектив изучения организаций предлагает ограниченный взгляд на роль организационных границ, не позволяющий изучить их во всей полноте.

2. В большинстве рассмотренных нами подходов к анализу организаций (за исключением, пожалуй, тех, что работают в интерпретативной традиции) практически не специфицируются внутренние организационные механизмы, за счёт которых границы конструируются и реконструируются. Границы не рассматриваются в качестве пространств или арен интеракций, обладающих определённой автономией от других организационных процессов. Другими словами, в организационных исследованиях практически не анализируются вопросы о том, каким образом, пользуясь соединением и перемещением границ, люди формируют различные организационные сущности.

3. И, наконец, ещё одно существенное ограничение состоит в том, что в рамках указанных подходов практически не осмысляется комплексный и многоуровневый характер организационных границ. Очевидно, что организационные границы являются многосоставными и реализуются на различных, но сосуществующих уровнях, а их изменения не всегда соотносятся друг с другом. К примеру, физические границы, зафиксированные в устройстве зданий, пропускных систем и различных уровнях доступа, могут трансформироваться совершенно в другой логике, чем символические границы, зафиксированные в целевых ориентациях и декларациях руководства организации. При этом границы на разных уровнях могут находиться в противоречии друг с другом и меняться асинхронно.

Указанные ограничения могут стимулировать дальнейшую концептуальную работу, связанную с изучением организационных границ. 


\section{Литература}

Бергер П., Лукман Т. 1995. Социальное конструирование реальности. М.: Медиум.

Девятко И. Ф. 2003. Социологические теории деятельности и практической рациональности. М.: Аванти плюс.

Димаджио П. Дж., Пауэлл У. В. 2010. Новый взгляд на «железную клетку»: институциональный изоморфизм и коллективная рациональность в организационных полях. Экономическая сочиология. 11 (1): 34-56. URL: http://ecsoc.hse.ru/issues/2010-11-1/index.html

Интервью с Уолтером Пауэллом: «Сегодня я настроен чуть более оптимистично, чем 10 лет назад». 2012. Экономическая социология. 13 (2): 8-16. URL: http://ecsoc.hse.ru/issues/2012-13-2/index.html

Мейер Дж., Роуэн Б. 2011. Институционализированные организации: формальная структура как миф и церемониал. Экономическая соичология. 12 (1): 43-67. URL: http://ecsoc.hse.ru/issues/2011-12-1/ index.html

Парсонс Т. 1993. Понятие общества: компоненты и их взаимоотношения. Thesis. 2: 94-122.

Радаев В. В. 2007. Захват российских территорий: новая конкурентная ситуачия в розничной торговле. М.: Изд. дом ВШЭ.

Чириков И. С. 2010. Жизнь организации «с точки зрения действующего»: перспектива теории договорного порядка. Журнал социологии и социальной антропологии. 13 (4): 158-173.

Щербина В. В. 2000. Социальнье теории организащии: Словарь. М.: ИНФРА-М.

Abbott A. 1995. Things of Boundaries. Social Research. 62 (4): 857-882.

Albert S., Whetten D. 1985. Organizational Identity. Research in Organizational Behavior. 14: 263-295.

Aldrich H.1979. Organizations and Environments. Englewood Cliffs: Prentice-Hall.

Aldrich H. 1971. Organizational Boundaries and Interorganizational Conflicts. Human Relations. 24 (August): 279-287.

Aldrich H., Ruef M. 2006. Organizations Evolving. London: Sage.

Becker H. 1974. Art as Collective Action. American Sociological Review. 39: 767-776.

Burrell G., Morgan G. 1979. Sociological Paradigms and Organizational Analysis. London: Heinemann.

Cai Y. 2011. What can be Learnt from Mergers in Chinese Higher Education. HEDDA 10 Conference Paper. Mimeo.

Coleman J. S. 1974. Power and the Structure of Society. New York: Norton.

Coleman J. S. 1990. Foundations of Social Theory. Cambridge, MA: Belknap Press of Harvard University Press. 
Cook K. S., Cheshire C., Gerbasi A. 2006. Power Dependence and Social Exchange. In: Burke P. (ed.). Contemporary Social Psychological Theories. Stanford, CA: Stanford University Press; 194-216.

Cook K. S., Yamagishi T. 1992. Power in Exchange Networks: A Power-Dependence Formulation. Social Networks. 14: 245-266.

Davis G. 2010 Do Theories of Organizations Progress? Organizational Research Methods. 13 (4): 690-709.

DiMaggio P. J, Powell W. W. 1991. Introduction. In: Powell W. W., DiMaggio P. J. (eds). The New Institutionalism in Organizational Analysis. Chicago: The University of Chicago Press; 1-40.

Emerson R. M. 1962. Power-Dependence Relations. American Journal of Sociology. 27 (1): 31-41.

Goffman E. 1967. Interaction Ritual: Essays on Face-to-Face Behavior. New York: Anchor.

Hannan M., Polos L., Carroll G. 2007. Logics of Organizational Theory: Audiences, Codes and Ecologies. Princeton: Princeton University Press.

Hannan M., Freeman J. 1977. The Population Ecology of Organizations. American Journal of Sociology. 82 (5): 929-964.

Hannan M., Freeman J. 1989. Organizational Ecology. Cambridge, MA: Harvard University Press.

Homans G. C. 1958. Social Behavior as Exchange. American Journal of Sociology. 63: 597-606.

Homans G. C. 1961. Social Behavior: Its Elementary Forms. New York: Harcourt; Brace and World.

Lamont M., Molnar V. 2002. The Study of Boundaries in Social Sciences. Annual Review of Sociology. 28: 167-195.

Mead G. H. 1934. Mind, Self and Society from the Standpoint of a Social Behaviorist. Chicago: University of Chicago Press.

Parsons T. 1951. The Social System. London: Routledge \& Kegan Paul Ltd.

Parsons T. 1960. Structure and Process in Modern Societies. Glencoe, IL: Free Press.

Parsons T., Shils E. Olds J. 1951. Values, Motives and Systems of Action. In: Parsons T., Shils E. (eds). Toward a General Theory of Action. Cambridge, MA: Harvard University Press; 47-278.

Perrow C. 1991. A Society of Organizations. Theory and Society. 20: 725-762.

Perrow C. 2002. Organizing America: Wealth, Power and the Origins of Corporate Capitalism. Princeton: Princeton University Press.

Pfeffer J., Salancik G. 1978. The External Control of Organizations. New York: Harper \& Row.

Powell W. W. 1990. Neither Market nor Hierarchy: Network Forms of Organization. Research in Organizational Behavior. 12: 295-336. 
Piore M., Sabel C. 1984. The Second Industrial Divide. New York: Basic Books.

Saxenian A. 1996. Regional Advantage: Culture and Competition in Silicon Valley and Route 128. Cambridge, MA: Harvard University Press.

Scott R., Davis J. 2007. Organizations and Organizing: Rational, Natural and Open System Perspectives. Upper Saddle River: Pearson Prentice Hall.

Selznick P. 1949. TVA and the Grass Roots. Berkeley, CA: University of California.

Simmel G. 1898. The Persistence of Social Groups. American Journal of Sociology. 3 (5): 662-698.

Simmel G. 1950. The Stranger. In: The Sociology of Georg Simmel. New York: Free Press; 402-408.

Simmel G. 1992. Soziologie. Untersuchungenüber die Formen der Vergesellschaftung. In: Georg Simmel Gesamtausgabe. Frankfurt a. M.: Suhrkamp.

Simmel G. 2007. The Social Boundary. Theory, Culture \& Society. 24: 53-56.

Skinner B. F. 1953. Science and Human Behavior. New York: Macmillan.

Strauss A. et al. 1963. The Hospital and its Negotiated Order. In: Freidson E. (ed.). The Hospital in Modern Society. New York: Free Press.

Thompson J. D. 1962. Organizations and Output Transactions. American Journal of Sociology. 68: 309-324.

Thompson J. D. 1967. Organizations in Action. New York: McGraw-Hill.

Yamagishi T., Cook K. 1993. Generalized Exchange and Social Dilemmas. Social Psychology Quarterly. 56: 235-248. 


\title{
НОВЫЕ КНИГИ
}

\author{
В. В. Радаев
}

\section{Предисловие к книге: Доббин Ф. 2012.} Формирование промышленной политики: Соединённые Штаты, Великобритания и Франция в период становления железнодорожной отрасли. М.: Изд. дом ВШЭ (серия «Социальная теория»)
(готовится к изданию)

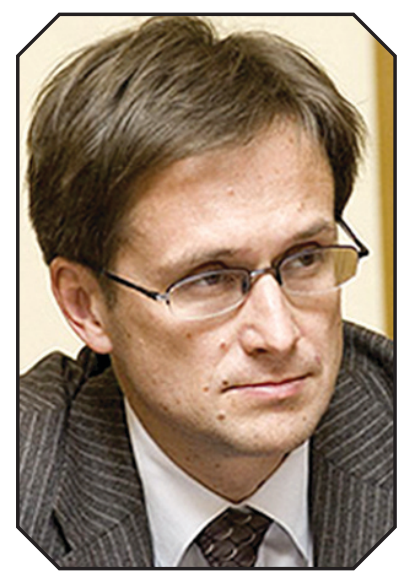

РАДАЕВ Вадим Валерьевич - доктор экономических наук, профрессор, заведующий кафедрой экономической социологии, первый проректор НИУ ВШЭ (Москва, Россия).

Email: radaev@hse.ru
Вниманию читателя предлагается одна из наиболее известных книг в современной экономической социологии. Её автор, Фрэнк Доббин, избрал для своего анализа три развитые капиталистические страны с примерно равным уровнем технологического развития - США, Францию и Великобританию. При этом во всех этих странах изучается один и тот же объект: становление и развитие железнодорожной отрасли. Интересно же то, что разворачивание отрасли происходило примерно в одно и то же время, но в каждой из этих стран аналогичные вопросы, связанные с планированием, финансированием, защитой конкуренции и обеспечением безопасности, решались совершенно по-разному. И в каждой из стран складывалась своя, очень не похожая на другие образцы промышленная политика. В чем заключались различия и чем они были вызваны - таков основной вопрос данной книги.

Чтобы объяснить различия в промышленной политике, Доббин прежде всего анализирует структуру государственной власти. Нужно сказать, что государство не страдает от недостатка внимания обществоведов, но чаще всего их рассуждения ведутся в терминах политологических моделей, представляющих государство как либеральное или корпоративистское, капиталистическое или стейтистское. Государство в книге Доббина предстаёт с совершенно другой стороны. Сердцевиной структуры государственной власти, основой всего политического порядка оказывается особая, присущая именно данному обществу политическая культура, которая помогает основным игрокам интерпретировать политический порядок и вырабатывать особые же, идеологически нагружённые смыслы, которые, в свою очередь, формируют парадигму промышленной политики.

При этом политическая культура понимается как совокупность исторически обусловленных взглядов людей, принимающих политические решения.

Источник: Dobbin F. 1994. Forging Industrial Policy: The United States, Britain, and France in the Railway Age. Cambridge [England], NY: Cambridge University Press. 
Эти взгляды институционализируются в структурах государственной власти, чтобы впоследствии с удивительной устойчивостью и своеобразностью влиять на контуры проводимой промышленной политики.

Заметим, что этот подход отличается от точки зрения, наиболее распространённой у экономических историков (среди них традиционно выделяется Альфред Чандлер), для которых способы хозяйственной организации выступают своего рода ответом на экономические вызовы времени.

Доббин также показывает, что реализация того или иного политического курса обусловлена не только и не столько организационными возможностями групп, принимающих наиболее важные решения. Сами эти решения во многом становятся результатами культурных предписаний, которые имеют отнюдь не конъюнктурную природу и вырабатываются несколькими поколениями.

Промышленная политика оказывается изоморфной моделям формирования государства, но этот институциональный изоморфизм осуществляется не прямым образом, а через содержательное посредничество политической культуры, которая особым образом определяет само понимание рационального действия и рационально организованной политики. Иными словами, институты, организующие хозяйственную и политическую жизнь, складываются параллельно под воздействием одних и тех же смысловых принципов.

Характерно, что Доббин не просто применяет социокультурный подход, подчёркивая важность символической борьбы в процессе формировании институтов. В его интерпретации основные институты оказываются социокультурными образованиями в самом фундаментальном смысле.

В книге представлен богатый фактический материал. Сравнение между странами производится по набору ключевых параметров, включая следующие: характер планирования и финансирования строительства железных дорог; решение технологических вопросов и проведение стандартизации; установление цен и поддержание конкурентного порядка. В результате выясняется, что власти Великобритании воздерживались от планирования железных дорог и практически никогда не финансировали их строительство. Единственный вопрос, в решение которого мог вмешиваться парламент, был связан с выведением земель под такое строительство, если оно затрагивало интересы частных землевладельцев. В США приоритет также отдавался частным компаниям, но правительства разных уровней финансировали значительную часть железнодорожного строительства. А вот во Франции планирование и финансирование практически целиком находились в руках государства, которое, впрочем, позволяло частным компаниям затем эксплуатировать железнодорожные линии под неусыпным оком государственных инженеров.

При эксплуатации построенных железных дорог французские государственные инженеры жёстко устанавливали стандарты безопасности, в то время как британцы обходились созданием комиссий, которые «информировали общественность» в расчёте на то, что дурная слава ударит по карману недобросовестных участников рынка (что случалось далеко не всегда). Американцы же полагались на решение подобных вопросов развитой судебной системой.

В США ни конгресс, ни правительства отдельных штатов первоначально не хотели вмешиваться в деятельность железных дорог, и в результате, например, каждая железнодорожная компания до определённой поры могла самостоятельно выбирать ширину колеи. Примерно то же происходило и в Великобритании. Во Франции подобный порядок (или, точнее, беспорядок) был бы решительно невозможен.

Что касается установления цен, то в Великобритании оно было отдано на откуп частным компаниям. А чтобы предотвратить хищническое ценообразование со стороны монополистов, поощрялось формирование картелей, что позволяло выживать множеству менее крупных фирм. Во Франции государство, 
напротив, диктовало цены шести региональным монополиям, которые оно само и определило. В США приоритет отдавался рыночным силам. При этом парадигма промышленной политики США часто поддерживала рынки в ущерб мелким предпринимательским фирмам. В то же время велась решительная борьба с картелями и трестами во имя защиты рыночной конкуренции.

Таким образом, в США промышленная политика формировалась прежде всего автономными местными сообществами и исходя из их суверенитета, во Франции - сильным централизованным государством, а в Великобритании она складывалась в интересах суверенных личностей и малых предпринимательских фирм. При этом промышленная политика не оставалась неизменной и с течением времени претерпевает непростую эволюцию с возможными колебаниями. Однако её парадигма, в которой заложены глубокие символические смыслы, остаётся относительно инвариантной, что сохраняет преемственность и отличает политический курс, проводимый в данной стране, от того, что происходит в других странах.

В целом представленное в книге экономико-социологическое исследование весьма трудно квалифицировать и отнести сколь-либо однозначно к какому-то известному нам направлению. Сам Доббин называет себя институционалистом, последователем веберианской традиции, но с не меньшим основанием его можно квалифицировать как приверженца культурно-исторического подхода. В то же время его работа представляет собой разновидность политической экономии, поскольку фокусируется на роли государства и формировании экономической политики. Не забудем и то, что речь идёт о компаративном исследовании. Слегка перефразируя Дж. Кэмпбелла, написавшего одну из рецензий на данную книгу, можно сказать, что такой институционализм возвращает понятие культуры в компаративную политическую экономию. В любом случае речь идёт о непростом сочетании разных подходов, которое осуществляется автором весьма органично, что называется, «без швов».

Вышедшая в 1994 г. книга не осталась незамеченной. Вскоре, в 1996 г., она получает от Американской социологической ассоциации Премию имени Макса Вебера. И впоследствии широко цитируется представителями самых разных исследовательских направлений.

С тех пор прошло немало времени. Не так давно, в 2009 г., вышла новая книга Доббина «Inventing Equal Opportunity» («Изобретая равные возможности»), изданная Princeton University Press, которая посвящена разработке корпоративных кодексов поведения персонала. Эта книга не менее успешна, награждена Американской социологической ассоциацией все той же Премией имени Макса Вебера. Но мы тем не менее решили не гнаться за новизной, а перевести более раннюю книгу — и потому, что она основана на историческом материале, и потому, что применённые в ней подходы по-прежнему актуальны.

Добавим, что ранее книга «Формирование промышленной политики...» уже была переведена на китайский язык (Shanghai People’s Press, 2008). Теперь, наконец, она появляется и на русском. (Мы опять отстаём от китайцев, но хочется в оправдание сказать, что намерение перевести эту книгу возникло ещё десятилетие назад, когда готовилось крупное издание переводов «Западная экономическая социология: хрестоматия современной классики»². Книга Доббина была как раз той самой «современной классикой», но тогда мы ограничились переводом двух существенных частей книги. И хотя при встрече я рассказал автору о планах по поводу перевода всего издания, руки до этого дошли далеко не сразу. Как водится, мы долго запрягаем, а китайцы сразу делают.)

2 См.: Доббин Ф. 2004. Формирование промышленной политики (фрагменты книги). В кн.: Радаев В. В. (научн. ред.; сост.). Западная экономическая социология: хрестоматия современной классики. М.: РОССПЭН; 607-631. 
В заключение несколько слов об авторе. Фрэнк Доббин имеет социологическое образование, получил звание бакалавра социологии в Оберлинском колледже, а затем $\mathrm{PhD}$ по социологии в Стэнфордском университете. Он начал свою профессиональную деятельность в Университете штата Индианы, затем полтора десятилетия преподавал в Принстонском университете, где работает сильная группа экономсоциологов, включающая Пола Димаджио, Вивиану Зелизер, Алехандро Портеса и др. Здесь Доббин получил звание профессора. С 2003 г. Фрэнк Доббин является профессором Гарвардского университета.

Профессор Доббин весьма активен в среде профессиональных экономсоциологов. Его статьи помещаются в наиболее известные хрестоматии. Он и сам издавал подобные хрестоматии ${ }^{3}$ В 2004-2005 гг. Фрэнк Доббин возглавлял в Американской социологической ассоциации секцию по организациям, профессиям и труду, а в 2009-2010 гг. - секцию экономической социологии.

Ранее в журнале «Экономическая социология» помимо фрагментов книги, о которой идёт речь, мы публиковали интервью с профессором Доббиным ${ }^{4}$. И следует сказать, что оно отличалось особой чёткостью суждений и структурированностью излагаемой позиции, которые присущи всем его основным работам.

Мы полагаем, что, помимо социологов, книга будет интересна представителям других социальных и гуманитарных наук - экономистам, историкам, политологам и культурологам. Поистине она представляет собой социологический взгляд, простирающийся поверх существующих дисциплинарных границ.

3 Cм.: Dobbin F. (ed.). 2004. The New Economic Sociology: A Reader. Princeton: Princeton University Press; см. также: Dobbin F. (ed.). 2004. The Sociology of the Economy. New York: Russell Sage Foundation.

4 См.: Экономическая социология. 2004. 5 (2): 6-12. URL: http://ecsoc.hse.ru/issues/2004-5-2/index.html 


\title{
Издержки торговых компаний по поддержанию систем наличных и безналичных платежей
}

\author{
Даты проведения: май — сентябрь 2012 г.
}

Коллектив Лаборатории экономико-социологических исследований Национального исследовательского университета «Высшая школа экономики» (НИУ ВШЭ) реализовал проект на тему «Издержки торговых компаний по поддержанию систем наличных и безналичных платежей».

Исполнители: д. э. н. В. В. Радаев (руководитель проекта), к. с. н. З. В. Котельникова, М. Е. Маркин, Е. А. Назарбаева, Н. В. Прокопова.

Исследование выполнено по заказу Ассоциации компаний розничной торговли (АКОРТ).

\section{Постановка проблемы}

В настоящее время активно обсуждаются меры по стимулированию безналичного денежного оборота в России. Одним из существенных препятствий для расширения карточных платежей помимо неразвитости инфраструктуры и недоверия потребителей считается сравнительно высокая ставка торговой уступки за проведение безналичных трансакций в торговых и сервисных организациях (особенно в сегменте малого и среднего бизнеса). Действительно ли данная ставка столь высока, и какие факторы влияют на её формирование? С какими дополнительными проблемами сталкиваются торговые компании в связи с обслуживанием безналичных платежей? Какие рекомендации могут быть предложены для решения этих проблем? Чтобы ответить на все эти вопросы, было проведено специальное исследование.

\section{Цель исследования}

Целью исследования является изучение величины издержек продовольственных и непродовольственных торговых компаний, связанных с поддержанием систем наличных и безналичных платежей (применительно к банковским картам разных типов).

\section{Задачи исследования}

1. Анализ ставок торговой уступки на рынках ЕС (по материалам исследований Европейского центрального банка и других финансово-кредитных учреждений ЕС).

2. Сравнительный анализ величины ставки торговой уступки в торговых компаниях, оперирующих на рынках России.

3. Исследование величины издержек по поддержанию бизнес-операций по приёму наличных и безналичных платежей.

4. Изучение барьеров, препятствующих проникновению безналичных платежей на российский рынок розничной торговли. 
5. Выработка рекомендаций по стимулированию безналичных трансакций на российском рынке розничной торговли.

\section{Объект и предмет исследования}

Основным объектом исследования выступают продовольственные и непродовольственные торговые компании разного размера, работающие на российском рынке розничной торговли.

Предмет исследования: сравнительный анализ издержек торговых компаний по поддержанию систем наличных и безналичных платежей в розничной торговле, а также основных проблем, возникающих у торговых компаний в связи с обслуживанием безналичных платежей.

\section{Основные методы сбора данных}

Сбор данных производился на основе стандартизованного опроса экспертов из числа сотрудников розничных компаний, отвечающих за финансовые вопросы. Собираемые данные концентрировались вокруг следующих основных параметров:

- общие сведения о торговой компании;

- общие сведения об эквайере и используемых платёжных системах;

— техническое обеспечение эквайринга;

— количественное соотношение наличных и безналичных платежей;

- сравнительная стоимость обслуживания наличного и безналичного оборота, её дифференциация в зависимости от типа платёжных средств, размера компании, основных товарных категорий и других факторов;

— ретроспективные, текущие и прожективные оценки влияния изменения ставок торговой уступки на величину торгового оборота.

В ряде случаев, помимо заполнения стандартизованной анкеты, с представителем торговой компании, отвечающим за соответствующую сферу деятельности, проводилось дополнительное интервью с целью получения более подробных объяснений и комментариев по основным вопросам исследования. Функциями интервью с представителями торговых компаний являлись более детальное раскрытие основных проблем, препятствующих развитию безналичных трансакций в торговых предприятиях, и выработка конкретных рекомендаций по возможным способам решения этих проблем.

При создании инструментария были учтены замечания представителей Министерства финансов РФ, Центрального банка РФ и Федеральной антимонопольной службы России.

\section{Формирование выборки и её основные параметры}

Перечень компаний и контакты их представителей были предоставлены ведущими деловыми ассоциациями. В исследовании приняли участие представители следующих организаций:

- Ассоциация компаний розничной торговли (АКОРТ);

- Ассоциация торговых компаний и товаропроизводителей электробытовой и компьютерной техники (РАТЭК);

- Ассоциация компаний интернет-торговли (АКИТ);

- Союз независимых сетей России (СНCР);

- Объединение работодателей малого и среднего бизнеса «ОПОРА». 
АКОРТ и РАТЭК обеспечили представительство федеральных торговых сетей, СНСР — региональных торговых сетей, «ОПОРА» - малых и средних торговых предприятий, АКИТ — интернет-магазинов.

Дополнительно были опрошены 15 региональных малых и средних компаний, не являющихся членами указанных ассоциаций. Сбор данных в этой части исследования производился Аналитическим центром Юрия Левады.

Всего в июле - августе 2012 г. были опрошены 42 компании, из них 50\% представляют Москву (как правило, являются федеральными торговыми сетями) и 50\% - регионы. По своему размеру отнесены к малым 16 опрошенных компаний $(38 \%)$, к средним - 8 компаний $(19 \%)$ и к крупным - 18 компаний (43\%). Малые компании выделены на основе официальных критериев ${ }^{1}$. Крупные и средние компании разделялись на основе сочетания нескольких признаков: количество магазинов, численность занятых и объем годовой чистой выручки.

Опрошенные компании работают в следующих товарных секторах:

- продукты питания (15 компаний);

- бытовая техника и электроника (15 компаний);

- товары для дома (15 компаний);

- одежда, спортивные товары (6 компаний);

- другие категории (11 компаний $)^{2}$.

Среди опрошенных компаний шесть интернет-магазинов (в основном это средние по размеру предприятия), остальные имеют оффлайновые торговые объекты, из них 10 компаний принимают безналичные платежи через Интернет, то есть работают одновременно оффлайн и онлайн. По результатам опроса была сформирована специальная база данных. Анализ данных осуществлялся с помощью статистического пакета SPSS+.

Дополнительно были записаны 13 интервью с финансистами опрашиваемых розничных компаний.

\section{Результаты исследования}

По результатам исследования опубликован аналитический отчёт (см.: Радаев В.В. и др. 2012. Издержки торговых компаний по поддержанию систем наличных и безналичных платежей: аналитический отчёт. Серия «Аналитика ЛЭСИ». Вып. 11. М.: Изд. дом ВШЭ. URL: http:/www.hse.ru/mag/analitics/archive. html).

1 Использованы положения Федерального закона «О развитии малого и среднего предпринимательства в РФ» от 24 июля 2007 г. № 209-Ф3.

2 Некоторые компании работают одновременно в нескольких секторах. 


\title{
УЧЕБНЫЕ ПРОГРАММЫ
}

\author{
Д. Х. Ибрагимова
}

\section{Практикум по прикладному анализу фринансового поведения населения}

(для направления «Социология» подготовки магистра для магистерской программы «Прикладные методы социального анализа рынков» НИУ ВШЭ)

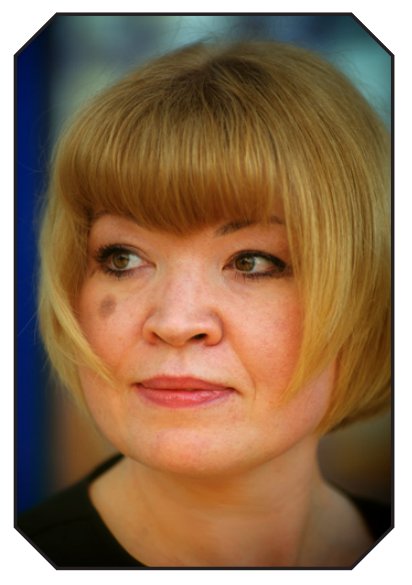

\section{ИБРАГИМОВА}

Диляра Ханифовна кандидат исторических наук, доцент кафедры экономической социологии НИУ ВШЭ (Москва, Россия).

Email: dibragimova@ hse.ru

\section{Цели освоения дисциплины}

Целями освоения дисциплины «Практикум по прикладному анализу финансового поведения населения» являются получение систематизированного представления о современных прикладных исследованиях в области финансового поведения населения, осведомлённость о возможностях анализа эмпирических макро- и микроданных о финансовом поведении населения.

\section{Место дисциплины в структуре образовательной программы}

Для специализации «Прикладные методы социального анализа рынков» настоящая дисциплина является дисциплиной по выбору.

Изучение данной дисциплины базируется на следующих учебных курсах:

- Методы анализа социологических данных;

- Основы экономической социологии;

- Социология финансового поведения населения;

- Социология потребления;

- Социально-экономическое поведение домохозяйств.

Для освоения учебной дисциплины студенты должны владеть следующими знаниями и компетенциями:

— знание фундаментальных теорий общей социологии;

- знание фундаментальных теорий экономической социологии;

- знание методов анализа социологических данных;

- умение осмыслить положения теорий социальных наук;

- умение аргументировать свою точку зрения.

Формы контроля знаний студентов см. в таблице 1. 
Таблий 1

Формы контроля знаний студентов

\begin{tabular}{|c|c|c|c|c|}
\hline \multirow{2}{*}{ Тип контроля } & \multirow{2}{*}{ Форма контроля } & \multicolumn{2}{|c|}{ Модуль } & \multirow{2}{*}{ Параметры } \\
\hline & & 1 & 2 & \\
\hline \multirow[t]{2}{*}{ Текущий } & $\begin{array}{l}\text { Работа на практических } \\
\text { занятиях }\end{array}$ & & 1 & $\begin{array}{l}\text { Подготовка презентации на основе мате- } \\
\text { риалов одной из аналитических статей }\end{array}$ \\
\hline & & & & $\begin{array}{l}\text { Подготовка презентации-обзора по одной } \\
\text { из тем }\end{array}$ \\
\hline \multirow[t]{2}{*}{ Промежуточный } & $\begin{array}{l}\text { Домашнее задание } \\
\text { (мини-проект) }\end{array}$ & & 1 & 10-12 страниц (15 тыс. знаков) \\
\hline & Проектный семинар & & 1 & $\begin{array}{l}\text { Презентация проекта или эссе. Формат } \\
\text { представления материала — Power Point. } \\
\text { Время выступления - } 10 \text { мин. }\end{array}$ \\
\hline Итоговый & Зачёт & 0 & 1 & Письменная работа на 60 мин. \\
\hline
\end{tabular}

\section{Порядок формирования оценок по дисциплине}

Итоговая оценка складывается с учётом нижеследующих весов:

- 5\% - посещаемость лекций и практических занятий;

- $15 \%$ - работа на практических занятиях;

- 50\% - домашнее задание (мини-проект);

— 30\% - оценка за письменную работу (зачёт).

\section{Критерии оценки знаний и навыков}

Оценки по всем формам контроля выставляются по 10-балльной шкале.

\section{Домашнее задание (мини-проект)}

Данный вид работы выполняется студентом самостоятельно на завершающих практических занятиях, а также дома. Каждый студент выполняет один мини-проект. Тема выбирается из предложенных преподавателем в программе или, в случае интереса студента к другой теме, обязательно согласовывается с преподавателем.

Сдаётся в письменной форме на последнем практическом занятии (где и происходят презентация и обсуждение работ).

Ориентировочный объём: 10-12 страниц.

Каждая работа включает следующее: название; фамилия, имя, отчество (ФИО) автора и номер группы; краткое обоснование темы; цели и задачи работы; гипотезы; объект и предмет исследования; данные (подготовка и выбор), полученные результаты. В качестве приложения приветствуются файлы синтаксиса SPSS.

Критерии оценки: адекватность гипотез, трансформации данных, интерпретации полученных результатов (расчётов). 
Проекты, основанные только на построении таблиц распределений и таблиц сопряжённости, оцениваются как неудовлетворительные.

\section{Работа на практических занятиях}

Критерии работы на практических занятиях следующие:

- умение сделать презентацию по заданным тексту (статье) и (или) обзору по указанной преподавателем теме и выступление с докладом по ней. При подготовке презентации и доклада необходимо, во-первых, выделить главную авторскую мысль; во-вторых, соответствовать структуре (плану изложения, представленному преподавателем); в-третьих, изложить кратко (10-15 мин) основное содержание заданных текста или обзора; в-четвёртых, сформулировать свои комментарии к прочитанному тексту (обзору), ответить на вопросы;

— участие в обсуждении изучаемой темы: комментарии, соображения, вопросы к докладчику (при обсуждении доклада).

\section{Письменная зачётная работа}

Письменная работа проводится в аудитории в присутствии преподавателя в рамках зачётной недели.

Каждый вариант состоит из 4-5 вопросов по программе. Вопросы могут быть нескольких типов и разного уровня сложности. Каждый вопрос оценивается определённым количеством баллов (в зависимости от сложности); баллы за каждый вопрос указаны в задании после формулировки вопроса. Использование каких-либо текстов и материалов на экзамене запрещается.

Время работы - 60 мин.

\section{Содержание дисциплины}

\section{Лекционная часть}

\section{Тема 1. Макроэкономическая статистика сбережений в России и других странах}

Система показателей макроэкономической статистики сбережений. Статистика национальных счётов. Основополагающие принципы построения Системы национальных счётов (CHC) и Баланса денежных доходов и расходов населения (БДР). Сектор домашних хозяйств в СНС. Счета доходов.

Статистика денежных потоков: преимущества и недостатки. Макроэкономическая статистика за рубежом. Методологические особенности процедур сбора исходных данных в разных странах. Проблемы макростатистики сбережений в России.

\section{Основная литература}

Пономаренко А. Н. 1997. Система национальных счётов. Экономический журнал ВШЭ. 1 (1): 96-120. URL: http://stat.hse.ru/hse/publications/PHSE97-1.pdf

Уровень и образ жизни населения России в 1989-2009 годах. 2011. Доклад к XII Международной научной конференции по проблемам развития экономики и общества. М.: Изд. дом ВШЭ; 10-25. URL: http://www.hse.ru/data/2011/04/05/1211687550/Mode_of_life.pdf 
Stroutchenevski A. 2002. Statistics on Savings and Investment in Russia. Russian Economic Trends. 11 (1): 42-47. URL: http://82.179.249.32:2069/login.aspx?direct=true\&db=bth\&AN=5894322\& site=ehost-live

\section{Дополнительная литература}

Иванов Ю. Н., Хоменко Т. А. 1998. Проблемы и методы статистики сбережения населения в соответствии с концепциями СНС. Экономический журнал ВШЭ. 2 (4): 508-515. URL: http://library.hse. ru/e-resources/HSE_economic_journal/articles/02_04_05.pdf

Пономаренко А. Н. 1997. Система национальных счётов. Экономический журнал ВШЭ. 2 (2): 78-103. URL: http://stat.hse.ru/hse/publications/PHSE97-2.pdf

Пономаренко А. Н. 1998. Система национальных счётов. Экономический журнал ВШЭ. 2 (1): 95-122. URL: http://stat.hse.ru/hse/publications/PHSE98-1.pdf

Пономаренко А. Н. 1998. Система национальных счётов. Экономический журнал ВШЭ. 2 (2): 245-268. URL: http://stat.hse.ru/hse/publications/PHSE98-2.pdf

Board of Governors of the Federal Reserve System. Guide to the Flow of Funds Accounts. Washington D.C. URL: http://www.federalreserve.gov/apps/fof/

Monetary and Financial Statistics Manual. 2000. International Monetary Fund. Washington D.C.; см. также на рус. яз: Руководство по денежно-кредитной и финансовой статистике. 2000. Вашингтон, округ Колумбия: Международный валютный фонд. URL: http:/www.imf.org/external/pubs/ft/mfs/manual/ rus/mfsmr.pdf

\section{Тема 2. Обследования потребительских финансов (Survey of Consumer Finance) (2 часа)}

Цели и задачи обследования потребительских финансов. Основные блоки вопросника, периодичность и дизайн обследования, возможности анализа данных. Использование данных обследований для целей экономической и социальной политики.

Обследования потребительских финансов в развитых странах. Прикладные результаты исследований.

\section{Основная литература}

Biancotti C., D'Alessio G. 2006. The Use of Micro-Level Data from the Bank of Italy's Survey of Household Income and Wealth: A Focus on Household Finance. IFC Bulletin. 26: 342-346. URL: http://www.bis.org/ ifc/publ/ifcb26s.pdf

Survey Data on Household Finance and Consumption: Research Summary and Policy Use (by Eurosystem Household Finance and Consumption Network, European Central Bank (ECB)), 2009. ECB Occasional Paper No. 100. Available at SSRN. URL: http://papers.ssrn.com/sol3/papers.cfm?abstract_id= $\% 20$ 1144504

White W. 2006. Measured Wealth, Real Wealth and the Illusion of Saving. IFC Bulletin. 26: 2-10. URL: http:// www.bis.org/ifc/publ/ifcb26_keynote.pdf 


\section{Дополнительная литература}

Barceló C., Bover O. 2006. Lessons from the Spanish Survey of Household Finances. IFC Bulletin. 26. URL: http://www.bis.org/ifc/publ/ifcb26o.pdf

Bricker J., Bucks B., Kennickell A., Mach T., Moore K. 2011. Surveying the Aftermath of the Storm: Changes in Family Finances from 2007 to 2009. URL: http:/www.federalreserve.gov/pubs/ feds/2011/201117/201117pap.pdf

BreuerW.,SalzmannA.J.2009.NationalCultureandHouseholdFinance.SocialScienceResearchNetworkWorking Papers. URL: http://papers.ssrn.com/sol3/papers.cfm?abstract_id=1448698\&rec=1\&srcabs=1144504

Kennickell A. B., Lusardi A. 2005. Disentangling the Importance of the Precautionary Saving Motive. URL: http:/www.federalreserve.gov/pubs/oss/oss2/papers/precautionary.nov05.2.pdf

Kennickell A. B. 2010. Try, Try Again: Response and Nonresponse in the 2009 SCF Panel. Federal Reserve Board. URL: http://www.federalreserve.gov/pubs/oss/oss2/papers/ASA2010.final.pdf

Сайты с описанием обследований потребительских финнансов в различных странах

\section{CШA}

Listing of questions: URL: http://www.federalreserve.gov/pubs/oss/oss2/2007/scfoutline.2007.pdf

Survey data (2007): URL: http://www.federalreserve.gov/pubs/oss/oss2/2007/scf2007data.html

\section{Испания}

The Spanish Survey of Household Finances: URL: http://www.bde.es/webbde/en/estadis/eff/eff.html

\section{Италия}

The Survey of Household Income and Wealth (SHIW): URL: http://www.bancaditalia.it/statistiche/indcamp/ bilfait/docum;internal\&action=_setlanguage.action?LANGUAGE=en

\section{Нидерланды}

DNB Household Survey (DHS) (formerly CentER Savings Survey): URL: http:/www.centerdata.nl/en/ TopMenu/Projecten/DNB_household_study/

The Eurosystem Household Finance and Consumption Survey (HFCS): URL: http://www.ecb.europa.eu/ home/html/researcher_hfen.en.html

Тема 3. Базы социологических данных по исследованию финансового поведения населения Poccuu (4 часа)

Российский мониторинг экономического положения и здоровья населения, РМЭ3 (Russian Longitudinal Monitoring Survey, RLMS) — лонгитюдное мониторинговое обследование домохозяйств. Основные разделы анкет и показатели. Блок вопросов по доходам, расходам и сбережениям домохозяйств. 
Обследование бюджетов домашних хозяйств (ОБДХ). Проблемы операционализации понятий «доход» и «сбережения» в обследованиях домохозяйств. Дневник домохозяйства, журнал домохозяйства и опросный лист в ОБДХ.

Мониторинг финансового поведения и доверия населения финансовым институтам (НИУ ВШЭ). Цель и задачи исследования. Операционализация понятий «доверие», «стратегия», «управление финансами в семье», «кредитная нагрузка» и «норма сбережений».

Обследование «Родители и дети, мужчины и женщины в семье и обществе» (РиДМиЖ), 2-я волна. Совместимость выборки с РМЭЗ. Основные сферы исследования. Состав домохозяйства. Социальнодемографические типы домохозяйств. Выявление доходов респондента, партнёра и домохозяйства в целом. Механизм принятия решений в домохозяйствах по различным вопросам.

\section{Необходимые ссылки}

RLMS: URL: http://www.hse.ru/rlms/spss

ОБДХ - данные, их описание, инструментарий обследования: URL: http://www.micro-data.ru/

РиДМиЖ - выборка, вопросник, направления исследования, данные: URL: http://www.socpol.ru/ gender/2_w.shtml

Основная литература

Ибрагимова Д. Х. 2008. Финансовое поведение населения: результаты эмпирических исследований. Российские домохозяйства накануне финансового кризиса: доходы и финансовое поведение. М.: НИСП; 115-207. URL: http://www.socpol.ru/publications/pdf/Ros_domohoz_2008.pdf

Организационные и методологические положения по обследованию домашних хозяйств. 1996. В сб.: Методологические положения по статистике. Вып. 1. М.: Госкомстат. URL: http://www.gks.ru/bgd/ free/B99_10/IssWWW.exe/Stg/d000/i000180r.htm

Сваффорд М., Косолапов М. С., Козырева П. М. 1999. Российский мониторинг экономического положения и здоровья населения (РМЭЗ): измерение благосостояния россиян в 90-е годы. Мир России. 3: 153-173. URL: http://www.hse.ru/journals/main.htm

\section{Дополнительная литература}

Ибрагимова Д. Х. 2010. Сберечь нельзя потратить: где российские средние классы ставили и поставят запятую? В сб.: Ясин Е. Г. (отв. ред.). Х Международная научная конференция по проблемам развития экономики и общества. М.: Изд. дом ВШЭ. 3; 261-274. URL: http://conf.hse.ru/2009/s3

Ибрагимова Д. Х., Кузина О. Е. 2009. Финансовое поведение населения России в условиях кризиса. Серия «Аналитика ЛЭСИ». Вып. 5: 6-40. URL: https://www.hse.ru/data/2010/08/05/1222047644/ Analytics_5.pdf

Уровень и образ жизни населения России в 1989-2009 годах. 2011. Доклад к ХІІ Международной научной конференции по проблемам развития экономики и общества. М.: Изд. дом ВШЭ; 47-51. URL: http:// www.hse.ru/data/2011/04/04/1211680508/\%D0\%A3\%D1\%80\%D0\%BE\%D0\%B2\%D0\%B5\%D0\%BD \%D1\%8C\%20\%D0\%B6\%D0\%B8\%D0\%B7\%D0\%BD\%D0\%B8-\%D1\%82\%D0\%B8\%D0\%BF.pdf 
Guariglia A., Kim B.-Y. 2004. Earnings Uncertainty, Precautionary Saving, and Moonlighting in Russia. Journal of Population Economics. 17 (2): 289-310. URL: http://82.179.249.32:2060/pqdlink?index=4\&d $\mathrm{id}=692133761 \&$ SrchMode=3\&sid=1\&Fmt=4\&VInst=PROD\&VType=PQD\&RQT=309\&VName=PQD $\& \mathrm{TS}=1316888262 \&$ clientId $=45975 \&$ aid $=1$

Skoufias E. 2003. Consumption Smoothing in Russia: Evidence from the RLMS. Economics of Transition. 11 (1): 67-91. URL: http://82.179.249.32:2548/ehost/pdf?vid=3\&hid=106\&sid=a9a82a26-ca7a-40fbb079-224f71fc04ed\%40sessionmgr112

Stillman S. 2001. The Response of Consumption in Russian Households to Economic Shocks. William Davidson Working Paper. 412. URL: ftp://repec.iza.org/RePEc/Discussionpaper/dp411.pdf

Тема 4. Психологические, социальные и экономические детерминанты финансового поведения: дискуссионные вопросы и результаты прикладных исследований (2 часа)

Состав и размер домохозяйства (коэффициент иждивенческой нагрузки, наличие и возраст детей), различные социально-демографические типы домохозяйств и их финансовые практики.

Когортный эффект. Формирование «квазипанели» для когорт путём склеивания разных волн непанельных данных. Профиль сбережений и потребления по возрасту.

\section{Основная литература}

Lint P. K., Livingstone S. M. 1991. Psychological, Social and Economic Determinants of Saving: Comparing Recurrent and Total Savings. Journal of Economic Psychology. 12 (4): 621-641. URL: http://82.179.249.32:2072/science/article/pii/016748709190003C

Yang Y., Land K. C. 2008. Age-Period-Cohort Analysis of Repeated Cross-Section Surveys. Fixed or Random Effects? Sociological Methods \& Research. 36 (3): 297-326. URL: http://www.unc.edu/ yangy819/files/ Yang_Land_SMR08.pdf

Дополнительная литература

Campbell J. Y. 1987. Does Saving Anticipate Declining Labor Income? An Alternative Test of the Permanent Income Hypothesis. Econometrica. 55 (6): 1249-1273. URL: http://82.179.249.32:2056/stable/1913556

Deaton A. 1991. Saving and Liquidity Constraints. Econometrica. 59 (5): 1221-1248. URL: http://82.179.249.32:2056/stable/2938366

Dynan K. E., Skinner J., Zeldes S. P. 2004. Do the Rich Save More? Journal of Political Economy. 112 (2): 397-444. URL: http://82.179.249.32:2056/stable/10.1086/381475

Livingstone S., Lunt P. 1993. Savers and Borrowers: Strategies of Personal Financial Management. Human Relations. 46 (8): 963-986. URL: http://82.179.249.32:2132/docview/231460174/13A7F5A255458DDC $670 / 4$ ? accountid $=45451$ 


\section{Тема 5. Социальные установки в отношении денег (сбережений и кредитов) и их связь с фри- нансовым поведением (2 часа)}

Понятие «социальные установки в отношении денег», его структура и методы измерения. Психометрическая шкала отношения к деньгам (money attitude scale) К. Ямаучи и Д. Темплера. Опросник А. Фернама «Шкала монетарных представлений и поведения».

Специфика отношения россиян к деньгам и их влияние на финансовое поведение. Установки населения России по отношению к сбережениям и кредитам. Возможности RLMS в подобных исследованиях.

Основная литература

Furnham A. 1985. Why Do People Save? Attitudes to, and Habits of Saving Money in Britain. Journal of Applied Social Psychology. 15 (5): 354-373.

Yamauchi K., Templer D. 1982. The Development of a Money Attftude Scale. Journal of Personality Assessment. 46 (5): 522-528. URL: http://82.179.249.32:2548/ehost/pdfviewer/pdfviewer?sid=2b8c7593e047-4242-9ce7-e8596ce0277c\%40sessionmgr13\&vid=5\&hid=8

\section{Дополнительная литература}

Фернам А., Аргайл М. 2005. Деньги. Психология денег и финансового поведения. СПб.: ПраймЕврознак.

Baker P. M., Hagedorn R. B. 2008. Attitudes to Money in a Random Sample of Adults: Factor Analysis of the MAS and MBBS Scales, and Correlations With Demographic Variables. Journal of Socio-Economics. 37 (5): 1803-1814. URL: http://82.179.249.32:2072/science/article/pii/S105353570800022X

Deineka O. S. 1996. Attitudes to Money and Entrepreneurship. In: Gray H., Foreman N., Hayes N.. (eds). Psychology in a Changing Europe. The First East-West Conf. in General Psychology. Leicester: British and east European Psychology Group.

Furnham A. 1982. Why are the Poor Always with Us? Explanations for Poverty in Britain. British Journal of Social Psychology. 21 (4): 311-322.

Тема 6. Сценарное моделирование кредитного поведения. Оценка возможностей участия населения в жилищных кредитных программах (2 часа)

Детерминанты кредитного поведения. Возможности и ограничения сценарного моделирования. Каковы обусловленные долгосрочными векторами развития и последствиями адаптации к эффектам кризиса 2010 г. особенности текущего момента с точки зрения спроса на кредитные ресурсы в секторе домашних хозяйств? Насколько спрос, предложение и институциональная среда современной России готовы к продвижению новых ипотечных продуктов?

\section{Основная литература}

Ибрагимова Д. Х., Сурков С. В. 2008. Оценка потенциального спроса и возможностей участия населения в жилищных кредитных программах. В сб.: Овчарова Л. Н. (отв. ред.). Российские домохозяйства накануне финансового кризиса: доходы и финансовое поведение. М.: Независимый институт социальной политики; 159-191. URL: http://www.socpol.ru/publications/pdf/Ros_domohoz_2008.pdf 
Овчарова Л. Н., Языков А. Д. 2010. Какие продукты на рынке ипотечного кредитования могут стать драйверами модернизационного развития. SPERO. 13: 43-68. URL: http://spero.socpol.ru/docs/ N13_2010_05.pdf

\section{Дополнительная литература}

Оиенка масштабов и динамики изменения платёжеспособного спроса на жильё и объёмов жилищного строительства в России. 2004. М.: Институт экономики города. URL: http://www.urbaneconomics. ru/texts.php?folder_id=80\&mat_id=122

Lea S. E. G., Webley P., Walker C. M. 1995. Psychological Factors in Consume Debt: Money Management, Economic Socialization, and Credit Use. Journal of Economic Psychology. 16: 681-701.

\section{Практические занятия}

Занятие 1 (2 часа). Знакомство с сайтами, содержащими макростатистические данные по сбережениям и доходам (сайт Росстата URL: http://www.gks.ru/wps/wcm/connect/rosstat/rosstatsite/main/population/ level/\#, сайт ЦБ РФ URL: http://www.cbr.ru/statistics/, сайт ФРС CША URL: www.federalreserve.gov. Знакомство с микроданными ОБДХ. Сравнение показателей денежных доходов, денежных расходов и расходов на конечное потребление, располагаемых ресурсов. Расчёт нормы сбережений по децильным и квентильным группам.

Занятие 2 (2 часа). Знакомство с зарубежными вопросниками по потребительским финансам. Анализ формулировок вопросов, их адаптация к российским реалиям. Обзор обследований потребительских финансов в разных странах (история вопроса, опросник, выборка, основная библиография по темам).

Занятия 3-4 (4 часа). Данные о доходах и сбережениях домохозяйств в базе RLMS. Показатели доходов и сбережений в базе данных. Региональные дефляторы и расчёт показателей реального дохода. Формирование суммарных показателей. Расчёт показателей душевого дохода. Квентильные и децильные группы доходов. Расчёт агрегированного показателя расходов. Сравнение показателей расходов и доходов. Расхождения и выбор показателя располагаемых ресурсов.

Показатели наличия и объёмов сбережений (в терминах потоков и запасов). Расчёт по децильным и квентильным группам распределения располагаемых ресурсов в целом, на текущие сбережения, на платежи по кредиту. Эластичность сбережений к доходам. Расчёт нормы сбережений и коэффициента кредитной нагрузки по децильным и квентильным группам. Построение профиля сбережений, потребительских расходов (по различным статьям) по возрасту. Методика формирования квазипанелей.

Занятие 5 (4 часа). Знакомство с базой данных «Мониторинг финансового поведения и доверия населения финансовым институтам». Определение состава домохозяйства, выделение социальнодемографических типов домохозяйств. Показатели сберегательного и кредитного поведения. Установки относительно кредитов и сбережений и их связь с поведенческими установками в сфере финансов. Применение методов факторного, кластерного и регрессионного анализа для исследования финансового поведения.

Занятие 6 (2 часа). Представление и обсуждение мини-проектов студентов. 


\section{Оценочные средства для текущего контроля и аттестации студента}

Темы письменных работ (мини-проектов)

1. Типы кредитного поведения домохозяйств (структуры кредитного портфеля, намерений относительно кредитования).

2. Типы домохозяйств по предпочитаемым целям и формам сбережений.

3. Взаимосвязь установок относительно сбережений и (или) кредитов и финансового поведения.

4. Сравнение данных о доходах и сбережениях различных типов домохозяйств и доходных групп по различным микроданным.

5. Регрессионный анализ факторов, влияющих на наличие у домохозяйства кредитов (кредитной истории).

6. Факторы пользования электронными деньгами (регрессионный анализ).

7. Регрессионный анализ факторов, влияющих на наличие у домохозяйства запасов сбережений и сберегательной активности (потоков сбережений).

8. Регрессионный анализ факторов, влияющих на наличие у домохозяйств финансовых стратегий. 


\title{
Международная конференция «Укоренённость и за её пределами: объясняют ли социологические теории экономическую реальность?»
}

\author{
Октябрь 25-28, 2012, Москва
}

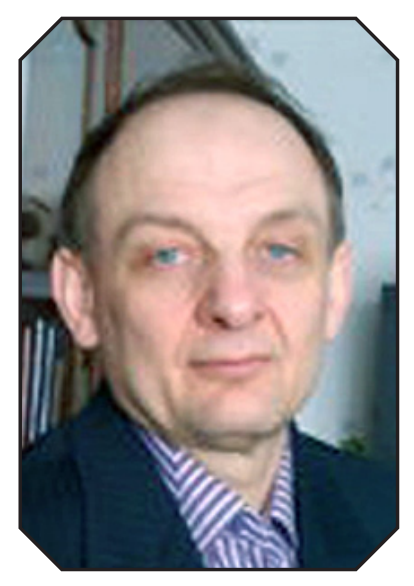

\section{СТАДНИК Игорь} Валентинович главный редактор экспертного канала «Открытая экономика» НИУ ВШЭ (Москва, Россия).

Email: stadnik@hse.ru
Организованная ВШЭ международная научная конференция «Embeddedness and Beyond: Do Sociological Theories Meet Economic Realities?» («Укоренённость и за её пределами: объясняют ли сочиологические теории экономическую реальность?») прошла 25-28 октября.

На конференциию прибыли более 200 сочуиологов из Австралии, Англии, Бразилии, Германии, Канадь, Новой Зеландии, США, Франции и других стран. Участники собрались, чтобы осмыслить развитие новой экономической сочиологии, оценить досточнства и ограничения данного подхода при объяснении ключевых экономических проблем.

Тематика докладов и дискуссий на конференции касалась финансовых рынков, глобализаџии и развития современного капитализма, рынков труда, роли экономических теорий в оформлении экономической жизни, значения культуры в современном хозяйстве, инноваций и организации.

Почётныли докладчиками форума стали Фрэнк Доббин (Гарвардский университет), Карин Кнорр (Университет Чикаго), Гленн Морган (Университет Кардиффа), Дэвид Старк (Колумбийский университет, Нью-Йорк), Лоран Тевено (Высшая школа сочиальных наук, Париж), Брайан Уичи (Келоггская школа менеджмента, Северо-Западный университет), Роберто Фернандес (Школа менеджмента им. Слоуна, Массачусетский технологический институт), Марион Фуркад (Университет Калифорнии, Бёркли).

Журнал «Экономическая социология» публикует репортажи о двух пленарных заседаниях, состоявшихся 25 и 26 октября 2012 г. Видеозаписи пленарных сессий и мини-интервью с участниками конференции доступны по aдpecy URL: http://www.esconf2012.hse.ru/

\section{И. В. Стадник, О. А. Серёгин}

\section{Современный капитализм и корни кризисов ${ }^{1}$}

Конференция «Укоренённость и за её пределами: объясняют ли социологические теории экономическую реальность?», проведённая ВШЭ 25-28

1 Источник: URL: http://www.hse.ru/news/recent/65353318.html 


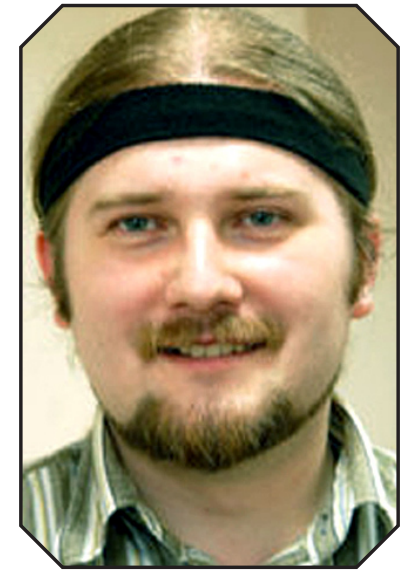

\section{СЕРЁГИН Олег}

Андреевич -

корреспондент,

заместитель

начальника отдела

новостей Дирекции по

порталам НИУ ВШЭ

(Москва, Россия).

Email: oseregin@hse.ru октября, была по-настоящему редким событием - она объединила ведущие силы экономической социологии всего мира. На первом пленарном заседании выступили Гленн Морган, профессор Университета Кардиффа, и Фрэнк Доббин, профессор Гарвардского университета.

Конференция проводилась при активном участии трёх крупнейших социологических ассоциаций планеты. Официальными организаторами выступали комитет «Хозяйство и общество» Международной социологической ассоциации и исследовательская сеть по экономической социологии Европейской социологической ассоциации. Активное содействие оказывала секция экономической социологии Американской социологической ассоциации. Непосредственным устроителем конференции в Москве выступила Высшая школа экономики.

Редкость события обусловлена тем, что ассоциации проводят свои конгрессы раз в несколько лет, с разным временным шагом, соответственно, и конференции их структурных подразделений (interim conferences) в промежутках между конгрессами проходят в разные годы. Предыдущая совместная конференция комитета «Хозяйство и общество» Международной социологической ассоциации и исследовательской сети по экономической социологии Европейской социологической ассоциации прошла более 10 лет назад.

В нынешней конференции участвовали около 200 социологов из Австралии, Англии, Бразилии, Германии, Канады, Новой Зеландии, США, Франции и других стран. Темами дискуссий стали развитие новой экономической социологии, оценка достоинств и ограничений данного подхода при объяснении ключевых экономических проблем. Среди тем, которые обсуждались на конференции, были финансовые рынки, глобализация и развитие современного капитализма, рынки труда, значение культуры в современном хозяйстве, инновации и организации и другое.

О другой встрече социологов-экономистов, состоявшейся в Москве в 1998 г., вскоре после дефолта и девальвации рубля, вспомнил профессор Корнелльского университета Виктор Ни. «Это был очень тяжёлый момент для российской экономики, - отметил он. - Но и социологам было очень важно “перегруппироваться”, начать думать над тем, как развивать социологию в позитивном направлении. Сегодня я рад видеть, что экономическая социология в России не просто пришла в себя, но и проявляет лидерские качества. Проведение нынешней конференции является тому подтверждением». Открывший конференцию первый проректор Высшей школы экономики Вадим Радаев напомнил, что предыдущая совместная конференция экономических социологов состоялась 12 лет назад, и тоже в Москве. Он рассказал, как за это время Высшая школа экономики, московский организатор конференции, выросла в один из ведущих национальных университетов, с мощным исследовательским началом, в том числе с сильнейшим в стране направлением социологических исследований.

Профессор Ни стал председателем первого пленарного заседания конференции, посвящённого теме «Развитие капитализма и институциональные 
изменения». Доклады на нём представили профессор Университета Кардиффа Гленн Морган и профессор Гарвадского университета Фрэнк Доббин.

В докладе «Capitalisms and Capitalism in the 21st century» («Капитализмы и Капитализм в XXI веке») Гленн Морган провёл грань между Капитализмом («с большой буквы») как мировой системой хозяйствования и национальными капитализмами, имеющими собственные особенности, институты, элиты. Было время, когда капитализмы и Капитализм развивались рука об руку. Однако глобализация увеличивает давление на капитализмы отдельных стран за счёт усиления влияния международных рынков, международных элит на внутренние институты и элиты.

Современный Капитализм, по Моргану, отличают многорыночные стратегии, географическая мобильность, сетевые формы руководства, проблемы с созданием стоимостей на нестабильных рынках, разрыв связи между отдельными звеньями цепочки по созданию новой стоимости (каждое звено может быть организовано и структурировано совершенно по-своему).

Самим своим существованием глобальный Капитализм оказывает давление на все стороны национальных капитализмов - налоговую политику государств и корпораций, рынки труда и системы социальной защиты, на систему образования и поддержки бизнеса государством.

Соответственно этот процесс привёл к реструктуризации и борьбе внутри национальных элит. В США и Великобритании выросла роль финансовой элиты, в Китае появилась система планирования преемственности, в Восточной Европе это привело к борьбе между элитами, в стабильных обществах (таких, как Франция или Япония) элиты в целом модернизировались, но напряжение внутри них растёт. Наконец, началось формирование европейской элиты внутри ЕС и глобальной элиты посредством транснациональных институтов.

Все эти процессы столкнулись с кризисом 2007-2009 гг., который Морган, по аналогии с Великой депрессией, назвал началом периода Великой умеренности (Great Moderation). В этом периоде обозначаются противоречия между Капитализмом и капитализмами, поскольку любые намерения национальных правительств сталкиваются — так и или иначе - с действиями глобальных фирм и организаций. В сочетании с необходимостью ужесточения денежной политики это создаёт давление на национальные элиты изнутри, ставя их перед вызовами, каких они не испытывали за весь послевоенный период.

Морган приходит к следующим выводам о современном состоянии Капитализма: он («большой» Капитализм) продолжает расширяться и модернизироваться, однако его рост и развитие ограничивают кризисы, которые он же и вызывает в капитализмах, подвергая ударам укоренённые национальные институты.

Национальные капитализмы не могут более поддерживать соответствие потребления и производства, поскольку не в силах уже использовать кредитные механизмы для поддержки государственного либо индивидуального потребления. Некоторые из капитализмов поэтому не в состоянии гарантировать социальный мир.

Взаимозависимость банков и государств, создаваемая финансовыми рынками, ставит под угрозу экономическую стабильность и политику ужесточения уже в международном масштабе. Государства сегодня не могут решить свои проблемы, действуя в одиночку, но и коллективные действия не делают страны сильнее. 
Капитализм как система разукоренённых (disembedded) экономических отношений расширяется и развивается неожиданными и непредсказуемыми путями, задевая и подчас разрушая укоренённые социальные порядки.

Возможность «двойного движения», по Поланьи, предполагающего параллельное развитие глобализации и укоренённых национальных институтов, зависит от наличия сильных государств и их способности действенно влиять на свою экономику и даже на международные порядки. Однако, считает Морган, поскольку глобализация замешана на идеях неолиберализма, в нынешних условиях для такого варианта нет перспектив.

Окончательный вывод Моргана пессимистичен: сильный Капитализм в сочетании со слабыми капитализмами порождает национальную и региональную неопределённость, приводит к локальным социальным кризисам с вероятностью выплеснуться за национальные границы и задеть остальных.

Фрэнк Доббин в своём докладе «The Fund-Manager-Value Revolution: How Institutional Investors Rewrote Shareholder Value» («Революция управляющих инвестиционными фондами: как институциональные инвесторы переопределили акционерную стоимость?») проанализировал, как изменение корпоративных ценностей в США, ставшее следствием кризиса 1970-х гг., подготовило почву для последних финансово-экономических кризисов.

Свой главный аргумент профессор Доббин сформулировал так: рост институциональных инвесторов (в том числе распоряжавшихся пенсионными накоплениями), игравших все более заметную роль в формировании корпоративных стратегий, привёл к тому, что менеджмент компаний стал заботиться в первую очередь о собственных интересах, а не об интересах акционеров. Из всего «меню ценностей» менеджеры выбирали те, что поощряли рискованные операции, сулившие большие прибыли им самим. Ситуация осложнялась тем, что и сами институциональные инвесторы также становились заложниками рискованных корпоративных стратегий. Один из самых показательных, на взгляд Фрэнка Доббина, примеров адаптации таких ценностей — судьба компании Enron.

При этом поиск новых стратегий менеджмента и развития компаний не был прихотью, он был необходим в условиях стагнации американского бизнеса в 1970-е гг. Решения предлагались самые разные. Очень популярным было изучение японского опыта корпоративного управления. Также исследователи говорили, что ответ на американские проблемы стоит искать в Италии, где семейный бизнес состоит из множества небольших фирм. Кто-то предлагал ориентироваться на государственный капитализм, ссылаясь на успехи французской промышленности.

Наконец, была предложена так называемая теория агентских отношений (agency theory). Она объясняла стагнацию тем, что менеджмент американских компаний был занят не предпринимательством (которое неизбежно связано с риском), а «строительством огромных империй, которые сделали бы бизнес их владельцев бессмертным». Теория агентских отношений указывала, что такой подход является ошибочным. Что предлагалось сделать вместо этого? Менеджеров нужно было «отучить» от создания безграничных корпораций и «приучить» к тому, что они «должны делать деньги для инвесторов».

Теория включала несколько предписаний по успешной работе с инвесторами. Во-первых, менеджеры должны были фокусироваться на увеличении стоимости акций фирмы, получая за это соответствующие бонусы и компенсации. Предполагалось, что не дивиденды, а возможность выгодно продать акции отвечают интересам акционеров. «Вот почему Apple никогда не заботилась о выплате дивидендов», заметил Фрэнк Доббин. 
Второе предписание касалось прозрачной финансовой отчётности. Компании необходимо быть максимально открытой, чтобы инвесторы могли принять решение, вкладывать в неё средства или нет.

В-третьих, менеджерам рекомендовалось заниматься проектами лишь в той индустрии, которую они хорошо знали. Планирование деятельности в других секторах брали на себя инвесторы. Кроме того, необходимо было прекратить вкладывать собственные доходы в развитие новых бизнесов — для этих целей, согласно теории агентских отношений, можно было привлекать кредиты. А контроль за всей этой деятельностью должен был находиться в руках независимого совета директоров.

Эти предписания, действительно, были направлены на усиление предпринимательской активности компаний, но в них крылось противоречие. С одной стороны, предписания поощряли больший риск (зарабатывайте больше, увеличивайте капитализацию, берите в долг на новые проекты). С другой тут же вводили ограничительные меры. О каком свободном предпринимательстве может идти речь, если компания обязана сразу раскрыть все свои карты, а любое начинание может быть «забраковано» советом директоров? Развивать производство? Отлично. Но почему только в одном секторе? Не складывать все доходы в одну корзину? Разумно. Но зачем же вместо этого залезать в долги? Даже установка на повышение стоимости акций была чревата тем, что менеджмент откажется от любых действий, выгодных в долгосрочной перспективе, которые приведут к краткосрочным потерям, и, наоборот, захочет максимизировать краткосрочную прибыль, не считаясь с долгосрочными последствиями такого решения.

Впрочем, главная опасность, по мнению Фрэнка Доббина, заключалась даже не в этом, а в том, что из всех декларируемых предписаний институциональные инвесторы были заинтересованы в соблюдении лишь двух - пресловутой финансовой прозрачности и «привязке» эффективности работы менеджеров к стоимости акций. «Бонусы институциональным инвесторам были основаны на том, насколько за год выросла стоимость управляемого ими портфеля, — пояснил докладчик. - Если его цена за год выросла, ты получал огромный бонус. При этом если на следующий год цена портфеля рухнет, это уже не твои проблемы, бонус у тебя никто не отберёт. Так что, управляя инвестиционным портфелем, менеджер из года в год ищет рост и может позволить себе игнорировать спады. Худшее, что с ним случится, — это увольнение. Но бонус-то останется при нём».

Точно так же стали работать и топ-менеджеры корпораций, искавшие краткосрочный рост и не особо заботившиеся о том, насколько устойчивым будет положение их компании в будущем. Поэтому крах Enron в 2001 г. и финансовый «пузырь», лопнувший в 2007 г., были неизбежными последствиями того пути развития, которого в последние 20-30 лет придерживались американские корпорации. «Проблема, с которой мы имеем дело сейчас, заключается в том, что ни одна из предложенных в последнее время реформ не направлена на изменение принципов этой новой формы корпоративного капитализма», — заключил Фрэнк Доббин. 


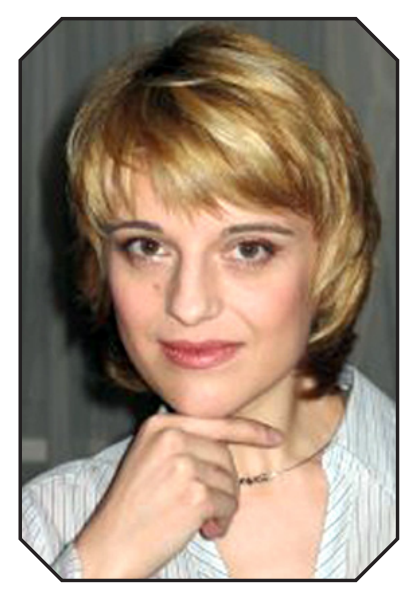

\section{БОГАТЫРЬ Наталья} Викторовна старший преподаватель кафедры экономической социологии НИУ ВШЭ (Москва, Россия).

Email: nbogatyr@hse.ru

\section{Н. В. Богатырь}

\section{Укоренённость и за её пределами: воздействие сетей²}

Второе пленарное заседание конференции «Укоренённость и за её пределами: объясняют ли социологические теории экономическую реальность?» прошло 26 октября. Оно было посвящено власти сетей, а современные исследования этого явления представляли профессор Массачусетского технологического института Роберто Фернандес и профессор Северо-Западного университета Брайан Уци.

\section{Масть - к масти}

Выступление на втором пленарном заседании профессора Массачусетского технологического института Роберто Фернандеса было посвящено власти сетей на рынке труда. Он начал с утверждения, что вера в их силу, в то, что, только создавая и преумножая контакты, можно достичь большего, - это основа как экономической социологии, так и повседневной экономической практики. Именно поэтому, перефразируя библейское «плодитесь и размножайтесь» (что по-английски звучит как «Go forth and multiply»), он обычно напутствует своих МВА-студентов фразой: «Идите и создавайте сети» («Go forth and network»). Однако любой неленивый учёный знает, что мы не успеваем с эмпирическими исследованиями экономической реальности, оставляя многие вопросы без ответов. Итак, что мы действительно знаем сегодня о роли сетей на рынке труда? С чем мы сравниваем сети, чтобы понять их значение?

Роберто Фернандес, охарактеризовав себя как скептика - «человека одной трети» (стакана), - призвал аудиторию на минуту представить, что сети на рынке труда не обладают никакой особой силой. По его мнению, исследования, доказывающие этот тезис, зачастую игнорируются, благодаря сетевой мифологии, начало которой положила знаменитая статья Марка Грановеттера. Все мы помним, что в поле зрения её автора попали кандидаты, получившие работу. Но что произошло бы, если бы Грановеттер писал о соискателях, которые работу не получили? Как это изменило бы наши представления о роли сетей на рынке труда?

Ещё один источник скептицизма докладчика - это исследования, авторы которых фокусируются на том, как именно люди и работа находят друг друга. В этот процесс вовлечены множество участников: те, кто ищет работу, те, кто подбирает сотрудников, и, наконец, те, кто посредничает в этом поиске. В своём обстоятельном обзоре недавних исследований Фернандес особое внимание уделил именно тем, что посвящены посредникам. Большая часть упомянутых им работ так или иначе затрагивает феномен социальной гомофилии (homophily), или склонности людей поддерживать связи с себе подобными и строить сети на основе различных сходств (докладчик напомнил собравшимся, что принцип гомофилии часто иллюстрируют поговорками «масть - к масти», «рыбак рыбака видит издалека» и им подобными, словом: «birds of a feather flock together» — «птицы одного оперения собираются вместе»).

2 Источник: URL: http://www.hse.ru/news/recent/65584766.html 
То, что работодатели, рассматривающие резюме, больше ценят кандидатов, пришедших через социальные сети, находит множество подтверждений. От чего же зависит поведение посредника, предоставление или непредоставление соискателю информации о вакансии? Какова цена превращения постороннего человека в своего? «Девяносто три тысячи долларов», - шутит, отвечая на этот вопрос, Фернандес, который вместе с коллегами недавно исследовал значение рекомендаций и направлений (referrals) и выделил в результате пять основных механизмов воздействия социальных сетей на рынок труда. Один из этих механизмов (M2) - уже упомянутая гомофилия. Остальные четыре - это расширение круга кандидатов (M1), стремление рекомендующего того или иного соискателя защитить свою репутацию (M3), дополнительная информация о кандидате (M4) и социальное обогащение в результате найма (M5).

Почему же для работодателей так важно, чтобы кандидаты были кем-то рекомендованы? Многие из них полагают, что сети сотрудников - это та часть их личного социального капитала, которая может и должна наращивать социальный капитал компании. В ходе своего исследования Фернандес и его коллеги поставили эксперимент. Они наблюдали за реакцией работодателей на одних и тех же кандидатов, пришедших через социальные сети или со стороны. Сначала, как и ожидалось, выяснилось, что представленные через социальные сети кандидаты оказывались успешнее. Затем выяснилось, что успешность людей со стороны при подаче повторного резюме немного возрастала. Но значительный её рост наблюдался тогда, когда соискатели, пришедшие в первый раз со стороны, во второй раз оказывались кем-то рекомендованы работодателю. Ещё примечательнее то, что уровень успешности кандидатов резко падал, если они переходили из категории пришедших через социальные сети в категорию людей со стороны. Из разговоров с менеджерами по персоналу и вице-президентами компаний выяснилось, что чем опытнее и старше они были, тем больше внимания обращали на то, направлен ли кем-то пришедший к ним соискатель должности.

Таким образом, резюмировал выступающий, социальные сети активно работают на рынке труда, способствуя как интеграции, так и сепарации. Сила сетей зависит от множества факторов, особенно когда речь идёт о различных меньшинствах и этнических группах.

Что же всё это означает для участников конференции? Как и своих МВА-студентов, профессор хотел бы убедить собравшихся, что их успех будет тем выше, чем эффективнее они будут строить и использовать свои социальные сети, которые помогут им открыть новые возможности. Но его сегодняшний ответ на вопросы «Что, если я сделаю это?», «Что, если я сделаю то?» таков: «Не знаю — впереди ещё много исследований».

Вопросы, действительно, последовали. Слушателей интересовало, объясняется ли успех рекомендованных кандидатов самим фактом их рекомендации или тем, что работодатель имеет о таких кандидатах информации больше, чем о пришедших со стороны. Может ли помочь научное знание о механизмах, управляющих процессом рекомендации, в повседневной жизни? Ведут ли коллеги докладчика исследования самой работы, а не только процесса её поиска?

Профессор Фернандес отметил, что механизмов, управляющих процессом сетевого посредничества, может быть существенно больше, чем выделили он и его соавторы. Идеальные исследования (gold standard studies) на рынке труда невозможны: исследователи всегда влияют на поведение исследуемых (например, он и его коллеги контролировали одну из сторон, а именно соискателей). В завершение своего выступления Фернандес предложил собравшимся ещё раз задуматься о ценности сетей. Безусловно, для работодателей в разных секторах рынка труда эта ценность различна. Часть распространяемой по сетям информации о кандидатах детализирована, часть - нет. Можно предположить, что там, где стоимость найма высока, особенно ценится детализированная информация. Но повсюду рекомендация 
от хорошего сотрудника предполагает, что кандидат будет так же хорош и подойдёт компании. И это тот из механизмов современного сетевого посредничества, который все работодатели стремятся использовать.

\section{О коллективной мудрости}

Брайан Уци начал своё выступление о коллективной мудрости и укоренённости с интригующего обещания, что результаты его последнего исследования не только откроют присутствующим нечто мистическое, но, возможно, даже помогут лучше узнать современный мир. Он пригласил собравшихся разделить с ним путешествие в жизнь нью-йоркского хедж-фонда, которое для него самого началось несколько лет назад. Особое внимание Уци в повседневной деятельности 60 наблюдаемых им трейдеров привлекли мгновенные сообщения, которыми они обменивались между собой и с тысячей других адресатов. Уци напомнил о своих предыдущих исследованиях финансовых рынков и отметил, что все полученные им данные фокусировались вокруг трёх тем: (1) то, что трейдеры планируют сделать; (2) то что происходит на рынке (здесь он напомнил о контагиозной природе этого рынка, но пояснил, что говоря о «заражении», имеет в виду не каскад банковских ошибок, а то особое состояние возбуждения (state of arousal), которое передаётся трейдерам, обменивающимся мгновенными сообщениями); и, наконец, (3) то, что докладчик назвал «синхронностью», содержание которой пообещал раскрыть позже. А пока он напомнил участникам конференции о гипотезе «коллективной мудрости», восходящей к идее Леонардо да Винчи о «синтезе разума».

Чтобы проиллюстрировать эту идею, он обратился к двум примерам - из будущего и из прошлого. Спок, популярный герой «Звёздного пути», обладал счастливой способностью соединять свой разум с разумами других героев, и результат такой комбинации был большим, чем простая сумма двух отдельных разумов. Френсис Дальтон, который в начале прошлого века провёл забавный эксперимент по комбинации разумов своих сограждан, пришёл к аналогичному результату. Разделив коровью тушу, он предложил экспертам и рядовым гражданам оценить совокупный вес частей. Затем сложил все названные цифры и вывел среднее арифметическое. Оказалось, что оно было точнее, чем отдельные ответы, даже если последние принадлежали экспертам. Уци суммирует примеры шуткой о том, что же такое разум: «Разум — это среднее (обобщённое) мнение в отношении среднего мнения».

Но какое отношение всё это имеет к трейдерам и их мгновенным сообщениям? По мнению Уци, самое непосредственное. Когда мы обмениваемся с людьми сообщениями о том, во что глубоко вовлечены, возникает эффект так называемой бесконечной дофаминовой петли (здесь необходимо заметить, что профессор Уци сопровождал своё выступление презентацией, без обращения к которой часть положений его доклада, возможно, покажется читателю не вполне понятной). Он выделил несколько категорий трейдерских сообщений: (1) общая информация о торговле, ценах и прочем; (2) социальная информация (кто кому нравится, с кем встречался и т. п.); (3) императивная информация (кто и что должен сделать); (4) интенциональная информация (о том, что сами трейдеры намерены делать). Систематизировав эту информацию, Уци обнаружил, что в ней содержится очень общее знание: несмотря на то что спонтанный обмен информацией предполагает высказывание своих мыслей, он также представляет собой попытку передать представления трейдеров о том, что происходит на рынке. Анализируя сообщения, мы можем узнать, как трейдер декодирует рынок. Таким образом, трейдеры обмениваются сообщениями для того, чтобы получить достаточно информации для осмысления рынка.

Уци проанализировал два миллиона сообщений и выяснил, что (без учёта вспомогательных) в них насчитывалось около 10 тыс. различных слов. Но только 500 слов оказались содержательными (типа Федеральный резервный банк, S \&P, то есть Standard \& Poor's и проч.). Он их выделил, установил связи между ними и организовал в сеть. Дальнейшее исследование этой сети обнаружило, что 500 зна- 
чимых слов разбиваются на две более или менее равные группы: 250 используются в одних ситуациях, 250 - в других. Трейдеры использовали слова той или иной группы в зависимости от того, что происходило на рынке. Все трейдеры постоянно говорят о волатильности (volatility). Существуют два вида волантильности, которые их беспокоят: сиюминутная волатильность (как рынок ведёт себя сегодня) и кратковременная волатильность (как рынок будет вести себя в ближайшие дни). Использование определённых слов предсказывает определённую неустойчивость рынка. Оказалось, что одна группа слов использовалась в предсказаниях сиюминутной, а другая — кратковременной волатильности. И здесь, возвращаясь к понятию коллективной мудрости, Уци пояснил, что эти предсказания оказывались более точными, чем прогнозы каждого трейдера по отдельности. Более того, он отметил, что они были даже более точными, чем данные использовавшихся на финансовых рынках количественных прогнозов. Чтобы продемонстрировать последнее утверждение, Уци пояснил, что точность, которую обеспечивала первая группа слов (анализ волатильности дня), оказывалась на 20\% выше, чем официально используемый индекс волатильности (VIX — volatility index). «Коллективную мудрость» мгновенных сообщений профессор Уци объяснил взаимной укоренённостью (embeddedness) этих сообщений: чем выше был уровень консенсуса трейдеров относительно прогноза волатильности дня, тем больше денег в целом им удавалось заработать.

Уцци отметил распространённое убеждение, что реакции сетей обычно являются цепными и поэтому их трудно измерить. Докладчик предложил вернуться к термину «активация» (activation), который появился в 1960-е гг. в публикациях психологов и обозначал состояние повышенной эмоциональной «проводимости» (conductance), то есть состояние, сигнализирующее о готовности людей к какомулибо действию. Чтобы составить «словарь активации» (activation dictionary) трейдеров, участники команды Уци исследовали эмоциональные ответы трейдеров на получаемые ими мгновенные сообщения и оценивали, в каких ситуациях они «возбуждались» и начинали использовать те же активирующие слова в своих собственных сообщениях. Это позволило исследователям наблюдать каскады (или «распространение психоза» - contagion), происходящие в сетях. Изменения в эмоциональных состояниях трейдеров меняли то, как они вели торги. Рост эмоций приводил к снижению торгов (это логично, потому что профессиональных трейдеров учат сохранять невозмутимость). Однако позже исследователи также выяснили, что повышение эмоциональной проводимости приводило к росту точности и аккуратности в торгах, что согласуется с точкой зрения о том, что в скачке интуиции когнитивное и эмоциональное соединяются.

Уци напомнил концепты, которые он использовал в своих предыдущих исследованиях, — момент коллективного великолепия (moment of collective brilliance) и синхронность (synchronicity). Первый непосредственно связан с понятием коллективной мудрости, второй заимствован у этологов, которые изучали коллективное поведение животных, птиц, рыб в естественной среде обитания. Этологи выяснили, что синхронизация происходит, когда перед лицом опасности каждый в стаде, стае или косяке выбирает один и тот же (оптимальный!) путь к спасению. У людей синхронизация происходит на уровне активности головного мозга. Уци решил взглянуть на трейдеров с точки зрения синхронности и выяснить, существует ли такой момент, когда трейдеры коллективно решают: «Сейчас!» — и начинают торговать? Он использовал методологию современной неврологии, известную как spike train analysis (с её помощью исследуются последовательности нейронных импульсов, идентичных по форме и размеру и происходящих в определённый промежуток времени). Команда Уци разработала на основе этой методологии свою собственную, которая позволила им исследовать моменты синхронизации трейдеров и построить сложную абстрактную модель. Выяснилось, что в такие моменты трейдеры, не зная о своей синхронности, имели вдвое больше шансов на очень удачные торги.

Уци задался вопросом: почему эти парни синхронизируются? Потому что все они гении и просто знают лучшее время для начала торгов или благодаря коммуникации и специфическому использованию мгновенных сообщений? Наблюдая изо дня в день за работой трейдеров, за их реакциями на мгновен- 
ные сообщения и за поведением на торгах, исследователи пришли к выводу, что чем больше трейдеры консультировались друг с другом при помощи сообщений, тем более синхронно они действовали. И это, как считает Брайан Уци, доказывает, что сети играют огромную роль в работе трейдеров и помогают им действовать лучше. А исследователям это позволяет по-новому взглянуть на укоренённость.

Профессор поясняет: мы всегда знали о богатстве концепта сетей и о том, что люди обмениваются информацией, но теперь мы также знаем, что значительная часть этой информации - мусор. Наш подход позволяет анализировать сообщения и проводить корреляции между их содержанием и фактическим поведением людей. Это первый большой шаг для нас. Второй шаг связан со временем. Мы точно знаем время отправки сообщений и можем связывать их с конкретными событиями.

В заключение Брайан Уци поблагодарил аудиторию и отметил, что социологи пока ещё в самом начале подобных исследований: именно поэтому в поисках объяснений своих данных он и его команда обращались за помощью к столь разным наукам — лингвистике, физике, этологии. 


\section{Contents and Abstracts}

Editor's Foreword (Vadim Radaev).

\section{Interviews}

Interview with James March: «If You Think You're a Good Scholar

You Do It Regardless of Whether It has Any Consequences»»

(translated by Dana Assalauova).

\section{New Texts}

\section{Irina Kozina}

Temporary Agency Workers: Social Characteristics and Employment

\section{Abstract}

The article is devoted to new forms of employment being formed under conditions of agency work (or leasing labour). The human capital theory postulates that marginal social groups are mainly involved into temporary agency work which doesn't provide workers with social guarantees. It can be found on the lowest step of the social ladder. So, social costs of increase in labour market flexibility may be very high and show up discrimination of agency workers, pushing them away from the labour market core and transforming them into working poors. The author considers the issues related to agency work in terms of social guarantees and proposes critical views on different topics including social characteristics of groups involved into agency work, motivation for getting jobs, assessment of work conditions, work satisfaction, etc.

Empirical data is generated from the survey of 1012 temporary agency workers employed for Kelly Services, Adecco and Ancor in seven Russian regions.

Research findings show that the structure of shared views on work agency is fragmented. It is resulted from co-existence of different demands in labour markets including demand for flexible employment. Comparing to labour markets in different countries the Russian one has some peculiarities. One of them implies that high educated young people are dominant among agency workers. They consider leasing labour as a direct way to stable employment. From the long term perspective temporary workers are oriented to getting stable positions and standard employment. It is concluded that temporary work practices are not discriminative and comparable with the overall labour markets in Russia.

Keywords: labor leasing; agency work; employment relations; social guarantees.

\section{New Translations}

\section{Frank Dobbin}

Forging Industrial Policy: The United States, Britain, and France in the Railway Age (translated by Yekaterina Golovlyanitsina).....

\section{Abstract}

The United States, France, and Britain use markedly different kinds of industrial policies to foster economic growth. To understand the origins of these different policies, this book examines the evolution of public poli- 
cies governing one of the first modern industries, the railroads. The author challenges conventional thinking in economics, political science, and sociology by arguing that cultural meaning plays an important role in the development of purportedly rational policies designed to promote industrial growth.

The journal publishes chapter 1 of Forging Industrial Policy — Political Culture and Industrial Rationality, in which Frank Dobbin proposes conceptual discussion on the origins of the cross-country differences in industrial policies.

Keywords: political culture; industrial policy; institutions; practices and sense; political and cultural approach; modern state; railroad industry.

\title{
Beyond the Borders
}

\author{
Joel Mokyr, Hans-Joachim Voth \\ Understanding Growth in Europe, 1700-1870: Theory and Evidence \\ (translated by Yuriy Kapturevsky).....
} 57

\section{Abstract}

Unlike most existing textbooks on the economic history of modern Europe, which offer a country-by-country approach, The Cambridge Economic History of Modern Europe rethinks Europe's economic history since 1700 as unified and pan-European, with the material organised by topic rather than by country. This first volume is centred on the transition to modern economic growth, which first occurred in Britain before spreading to other parts of western Europe by 1870. Each chapter is written by an international team of authors who cover the three major regions of northern Europe, southern Europe, and central and eastern Europe. The volume covers the major themes of modern economic history, including trade; urbanization; aggregate economic growth; the major sectors of agriculture, industry and services; and the development of living standards, including the distribution of income. The quantitative approach makes use of modern economic analysis in a way that is easy for students to understand..

The journal publishes the chapter 1 «Understanding Growth in Europe, 1700-1870: Theory and Evidence» by Joel Mokyr and Hans-Joachim Voth of The Gifts of Athena, in which authors summarize recent research by growth economists and contrasts their interpretations with the existing historical evidence and recent findings of economic historians.

Keywords: economic growth; economic history; institutions; human capital; technology; culture.

\section{Debute Studies}

\section{Mariya Neuvazhaeva}

Institutional Frameworks of the Development of Non-Government Universities in Russia..... 102

\section{Abstract}

The paper proposes a critical study focusing on the development of non-government higher education sector in Russia from new institutionalism perspective in economic sociology. Conditions under which private universities spread in other countries are identified. In some countries non-governmental universities successfully complement governmental ones, in some countries private universities displace state universities. Recent 
research shows that private sector produces some organizational divergences (especially under privatization and emerging liberal markets). However the presented paper argues that Russian case is specific. Governmental and non-governmental universities are initially intertwined. This fact provokes us into thinking about the Russian higher education system from the alternative point of view. Based on in-depth interviews with founders and lecturers from Moscow private universities and the survey of students the paper intends to trace structuration of non-governmental education field and to demonstrate impacts of institutional isomorphism mechanisms on private universities.

Keywords: non-governmental universities; new institutionalism; isomorphism; higher education.

\section{Professional Reviews}

Igor Chirikov

Four Methods for Defining Organizational Boundaries in Sociology

Abstract

The paper codifies the theoretical perspectives in sociology of organizations related to studies in organizational boundaries. Four methods for conceptualizing organizational boundaries are identified, depending on a key metaphor which each method proposes. The presented metaphors include (1) boundary as membrane (flap); (2) boundary as convention; (3) boundary as interface; (4) boundary as forefront. In addition, the paper discusses the organizational perspectives' general methodological drawbacks in studying organizational boundaries.

Keywords: organizational boundaries; contingency theory; negotiated order theory; resource dependence theory; new institutionalism; organizational theory.

\section{New Books}

\section{Vadim Radaev}

Preface to Russian translation (2012. Forthcoming):

Dobbin F. 1994. Forging Industrial Policy: The United States, Britain,

and France in the Railway Age. Cambridge [England], NY: Cambridge University Press.

\section{Research Projects}

Costs for Supporting Cash and Cashless Payments

in Russian Retailing (headed by Prof. Vadim Radaev)

\section{Syllabi}

Dilyara Ibragimova

Workshop on Applied Behavioral Finance Studies

\section{Conferences}

International Conference Embeddedness and Beyond:

Do Sociological Theories Meet Economic Realities?, Moscow, October 25-28, 2012 


\section{About the Authors}

\section{Chirikov, Igor}

PhD Student, Faculty of Sociology; Director, Center of Internal Monitoring, National Research University Higher School of Economics (HSE).

igor.chirikov@gmail.com

\section{Dobbin, Frank}

Professor of Sociology, Department of Sociology, Harvard University.

frank_dobbin@harvard.edu

\section{Ibragimova, Dilyara}

Candidate of Science in History, Associate Professor, Faculty of Sociology; Senior Research Fellow, Laboratory for Studies in Economic Sociology, National Research University Higher School of Economics (HSE).

dibragimova@hse.ru

\section{Kozina, Irina}

Candidate of Science in Sociology, Professor, Faculty of Sociology; Head, Department of Sociological Research Methods; Leading Research Fellow, Institute for Social Development Studies, National Research University Higher School of Economics (HSE).

ikozina@hse.ru

\section{March, James}

Jack Steele Parker Professor of International Management, Emeritus, Graduate School of Business; Departments of Political Science and Sociology, Stanford University.

march@stanford.edu

\section{Mokyr, Joel}

Robert H. Strotz Professor, Department of Economics, Northwestern University.

j-mokyr@northwestern.edu

\section{Neuvazhaeva, Mariya}

MA Student, Faculty of Sociology, National Research University Higher School of Economics (HSE).

m.neuvazhaeva@gmail.com

\section{Radaev, Vadim}

Doctor of Science in Economics, Professor, Faculty of Sociology; Chair, Department of Economic Sociology; Head, Laboratory for Studies in Economic Sociology; First Vice-Rector, National Research University Higher School of Economics (HSE).

radaev@hse.ru

\section{Voth, Hans-Joachim}

ICREA Research Professor, Department of Economics, Universitat Pompeu Fabra.

jvoth@crei.cat 